\title{
FEMINIST ENCOUNTERS
}

\author{
A JOURNAL \\ OF CRITICAL STUDIES \\ IN CULTURE AND POLITICS \\ e-ISSN: 2542-4920
}

Volume 1, Issue 1 (Autumn 2017)

\section{Editor-in-Chief \\ Sally R. Munt}

Sussex Centre for Cultural Studies, University of Sussex (UK)

Guest Editors

Salla Peltonen

Åbo Akademi University (Finland)

Marianne Liljeström

University of Turku (Finland) 
This page intentionally left blank. 


\section{FEMINIST ENCOUNTERS: A JOURNAL OF CRITICAL STUDIES IN CULTURE AND POLITICS}

Founded in 2017, Feminist Encounters is a journal committed to argument and debate, in the tradition of historical feminist movements.

In the wake of the growing rise of the Right across the world, openly neo-fascist national sentiments, and rising conservative populism, we feminists all over the world are needing to remobilise our energies to protect and advance gender rights.

Feminist Encounters provides a forum for feminist theorists, scholars, and activists to communicate with each other, to better educate ourselves on international issues and thus promote more global understanding, and to enhance our critical tools for fighting for human rights.

Feminism is an intellectual apparatus, a political agenda, and a programme for social change. Critical analysis of how gender discourses produce cultural identities and social practices within diverse lived realities is key to this change. We need to think more sharply in order to strategise well: as the discourses of conservatism renew and invigorate themselves, so we as feminist scholars need to be refining our amazonic swords in order not just to respond effectively but also to innovate our own ideas for equality and social justice.

We are, of course, committed to intersectionality, a vital lens through which to see the contours of race/ethnicity, class, sexuality, age/ability, and explore how gendered scripts get lived, and filtered through these specificities of cultural organisation. Lived experience is never codified in terms of gender alone, and so our research will always be sensitive to the nexus of lived oppressions.

The journal has a large editorial board and journal team, consisting of over forty scholars in twenty countries. This is deliberately inclusive in order that we can promote diversity and engage with different concerns from across the world. Our aim is not to simply talk to ourselves, reconfirming our localised assumptions, but to generate feminist encounters across regions, even if this is sometimes uncomfortable. Globalisation has been a triumph of neoliberalism, but digital technologies have also flattened and reduced the distance between us in dramatic ways, so that now we can talk to each other with unanticipated ease.

This new access to each others' voices has also brought challenges to the way we think and do things, so that being a feminist today might be quite a different prospect to a person living in China, Iran, Norway, South Africa or the UK. Second Wave Feminism used the idea of 'sisterhood' to invoke solidarity between women. I've always rather liked Andrea Dworkin's claim, though, that: "Feminism is a political practice of fighting male supremacy in behalf of women as a class, including all the women you don't like, including all the women you don't want to be around, including all the women who used to be your best friends whom you don't want anything to do with anymore." The notion of sisterhood was challenged by Black feminists in the 1980s as being too conceptually white, thus bell hooks' trenchant critique that: "the idea of 'common oppression' was a false and corrupt platform disguising and mystifying the true nature of women's varied and complex social reality". In the 1990s and 2000s it has been fair to say that feminist theory and Feminist Studies since have engaged more intentionally and deliberately with intersectionality - though Jennifer Baumgardner did caution us that: "Sisterhood was never about everybody agreeing ....".

For our journal, sisterhood must expand and embrace our transgender allies and our men friends, reminding us that sibling relationships are rarely straightforward or inevitably blessed by golden moments of total affinity. Thus, Feminist Encounters welcomes the opportunity for new kinds of international discussions in the spirit of collaboration and critical intellectual enquiry. We hope for productive agreement and disagreement, and the shared struggle of fighting gender oppression, with our minds, hearts, and bodies, as the times demand. 


\section{EDITORIAL BOARD}

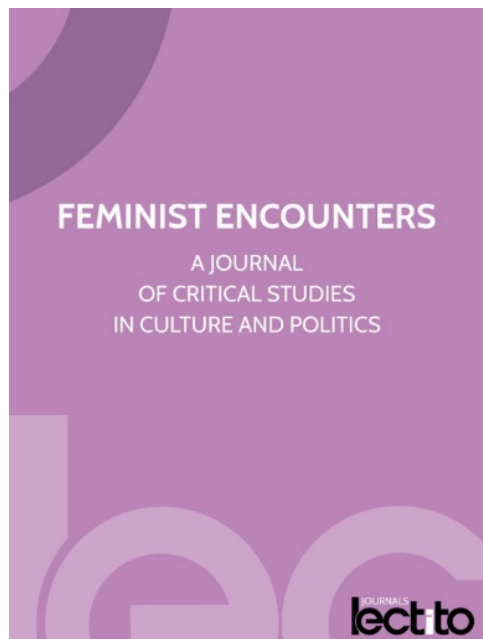

\section{Production Editor}

Sinead Baldwin, University of Central Lancashire (UK)

\section{$\underline{\text { Reviews Editors }}$}

Carla Cerqueira, Lusophone University of Porto (Portugal)

Ben Lu, Sociology Department, The Hong Kong University (China)

\section{Editorial Board}

Amy Motlagh, The American University in Cairo (Egypt) Annabel Cooper, University of Otago (New Zealand)

Annelies Moors, University of Amsterdam (The Netherlands)

Andrew Yip, The University of Nottingham (UK)

Anita Biressi, University of Roehampton (UK)

Aristea Fotopoulou, University of Brighton (UK)

Beatrice Halsaa, University of Oslo (Norway)

Busra Sultana, University of Dhaka (Bangladesh)

Charlotte Beyer, University of Gloucestershire (UK)

Catherine Jean Nash, Brock University (Canada)

Clara Fischer, University College Dublin (Ireland)

Gayle Rubin, University of Michigan (USA)

Gert Hekma, University of Amsterdam (The Netherlands)

Gloria Wekker, University of Utrecht (The Netherlands)

Gopinath Arunima, Jawaharlal Nehru University (India)

Heather Love, University of Pennsylvania (USA)

Imogen Tyler, Lancaster University (UK)

Joyce Goggin, University of Amsterdam (The

Netherlands)

Katherine Johnson, University of Brighton (UK)

Katherine Natanel, SOAS University of London (UK)

Katie King, University of Maryland (USA)

Katrina M. Powell, Virgina Tech (USA)

\section{Editor-in-Chief}

Sally R. Munt

Sussex Centre for Cultural Studies, University of Sussex (UK)

s.r.munt@sussex.ac.uk

Guest Editors

Salla Peltonen

Åbo Akademi University (Finland)

Marianne Liljeström

University of Turku (Finland)
Krassimira Daskalova, Sofia University (Bulgaria)

Kris Franklin, NYU Law School (USA)

Lata Singh, Jawaharlal Nehru University (India)

Lila Abu-Lughod, Columbia University (USA)

Linda Morrice, University of Sussex (UK)

Marianne Liljestrom, University of Turku (Finland)

Mary McAuliffe, University College Dublin (Ireland)

Melissa Steyn, University of Witwatersrand (South Africa)

Mildred Lodiaga, Kenyatta University (Kenya)

Nigar Degirmenci, Pamukkale University (Turkey)

Paula Hamilton, University of Technology Sydney

(Australia)

Ronelle Carolissen, Stellenbosch University (South Africa)

Salima Tasdemir, University of Exeter (UK)

Sarah Chinn, Hunter College, CUNY (USA)

Sarah-Jane Page, Aston University (UK)

Sarala Krishnamurthy, Namibia University of Science and Technology (Namibia)

Sasha Roseneill, Birkbeck Institute for Social Research (UK)

Sherri Foster, Washington College (USA)

Sonja Tiernan, Liverpool Hope University (UK)

Srimati Basu, University of Kentucky (USA)

Sue Thornham, University of Sussex (UK)

Tamara Shefer, University of Western Cape (South

Africa)

Ulrika Dahl, Uppsala University, (Sweden)

Viv Bozalek, University of Western Cape (South Africa)

Zhou Juan, Changsha University of Science \& Technology (China)

\section{Editorial Assistants}

Carina Westling, University of Sussex (UK) Jasmina Šepetavc, University of Ljubljana, (Slovenia) Rosa Whitecross, University of Sussex (UK) Trish Hamilton, University of Western Ontario, (Canada) 
A Critique of Our Own? On the Epistemic Habits of Academic Feminism

\title{
TABLE OF CONTENTS
}

\author{
Introduction
}

On Feminist Epistemic Habits and Critique

Marianne Liljeström, Salla Peltonen

https://doi.org/10.20897/femenc.201701

\section{Research Articles}

1 Mood, Method and Affect: Current Shifts in Feminist Theory Ellen Mortensen https://doi.org/10.20897/femenc.201702

2 Academic Feminisms: Between Disidentification, Messy Everyday Utopianism, and Cruel Optimism

Nina Lykke

https://doi.org/10.20897/femenc.201703

3 Religion, Intersectionality, and Epistemic Habits of Academic Feminism. Perspectives from Global Feminist Theology

Elina Vuola

https://doi.org/10.20897/femenc.201704

4 Fluid Reading Practice: On the Queer Potential of Studying Nonhuman Animals Sari Irni

https://doi.org/10.20897/femenc.201705

5 A Pace of Our Own? Becoming Through Speeds and Slows - Investigating Living Through Temporal Ontologies of The University

Malou Juelskjær, Monika Rogowska-Stangret https://doi.org/10.20897/femenc.201706

6 Counting Zero: Rethinking Feminist Epistemologies Xin Liu https://doi.org/10.20897/femenc.201707

7 Music Videos as Black Feminist Thought - From Nicki Minaj's Anaconda to Beyoncé's Formation Katariina Kyrölä https://doi.org/10.20897/femenc.201708

8 Perceiving Shit as Shit: On the Grammar of Patriarchy in Solanas' SCUM Manifesto Salla Peltonen, Mio Lindman, Sara Nyman https://doi.org/10.20897/femenc.201709

\section{Interviews}

1 Assessing Critique, Scholarly 'Habits', Queer Method and 'Turns': An Interview with Heather Love

Salla Peltonen, Heather Love

https://doi.org/10.20897/femenc.201710

2 Investigating Desires, Political Projects and Epistemic Habits in Academic Feminism: A Conversation with Robyn Wiegman

Salla Peltonen, Robyn Wiegman

https://doi.org/10.20897/femenc.201711 
http://www.lectitopublishing.nl

https://www.facebook.com/LectitoJournals/

https://twitter.com/lectitojournals

$\mathcal{S}_{+}$https://plus.google.com/110901545130385419486

in https://www.linkedin.com/in/lectito-journals9a675010b/ 


\title{
EDITORIAL
}

\section{On Feminist Epistemic Habits and Critique}

\author{
Marianne Liljeström ${ }^{1 *}$, Salla Peltonen ${ }^{2}$
}

Published: October 30, 2017

\section{INTRODUCTION}

\section{Feminist critique}

Critique within academic feminism has become the object of much debate especially during the last decade. The current interest and discussion about critique and postcritique is evidenced by the increasing number of publications that in various ways assess the role and status of critique and critical theory as a driving force in academic work. Critique has a longstanding role within feminist studies, especially regarding questions of objectivity, truth, reality, interpretation, value, fact, description and representation and the ways in which scientific knowledge has uncritically reproduced notions of difference and hierarchies (Haraway 1988). Critique has especially concerned questions related to the gendered nature of knowledge, exploring and exposing ways in which tacit understandings of categories of differentiation gain meaning within various academic disciplines (Butler 1990). In addition to the larger debates around critique, its value and usefulness as an academic practice, we have also witnessed an ongoing debate about the role critique has for disciplines concerned with 'identity knowledges' (Wiegman 2012). Indeed, critique is one of the foundational characteristics of feminist, gender and queer studies: these disciplines have since their formation as academic disciplines been defined as oppositional, anti-institutional and critical by default (see Hemmings 2011, Wiegman 2012, Dahl et al. 2016).

Critique is thus internally aligned with questions of knowledge production, ethics of research ('situated knowledges') and the politics of academic work, but also to how we as feminist academics understand and envision our work as related to questions of transformation, emancipation, and social justice. Discussions about the researcher's reflexivity, accountability and positionality are part of what makes feminist studies critical in its endeavour. Engaging with questions of privilege in revealing how heteronormativity, white epistemologies and western notions of subjectivity inform our work has, among others, raised questions of ethics and accountability.

Critique can be described as a common denominator for the various disciplines that form the interdisciplinary field of gender studies and as a core aspect of its methodologies and theories. Although a large part of the current debates on critique, and especially regarding interpretation and ways of reading, concerns literary studies and literary critics, the philosophical, theoretical and methodological questions they pose have a general relevance beyond disciplinary boundaries as they deal with larger claims about understanding, knowledge, politics and ethics. Hence critique is of relevance both in the social sciences, natural sciences and within the humanities. How we choose our methods, instruments of measurement, criteria, concepts and materials matter and assessing the ways in which we as researchers are implicated in our own activity in producing our objects of study is relevant to anyone interested in the politics, ethic and pedagogy of their own work (Barad 2007).

A central philosophical background to critique as it is practised within interdisciplinary feminist studies lies within poststructuralist approaches to knowledge where the conditions of knowledge production are highlighted. This Fouauldian gesture of historicising not only ideas, but the conditions of their making is central to the ways in which academic feminism has recently come to assess its own practices (Hemmings 2011, Wiegman 2012). The 'heydays' of feminist theory in the 1990s can be specifically described as an era when feminist thinkers engaged with critique in different ways. Judith Butler's Gender Trouble and Eve Sedgwick's Epistemology of the Closet, both published in 1990, are cases in point, revolutionising the philosophy of gender and hailed as the foundational work of queer theory. A major concern in the ongoing debates is how to reassess the legacy of this body of work and particularly the value of Eve Sedgwick's division between paranoid and reparative readings (Sedgwick 2003). Sedgwick's article pinpoints the attitude and spirit of critique, and both describes, defines and questions one of the 
major 'epistemic habits' of academic scholars engaged in critique, namely 'the hermeneutics of suspicion' (the term coined by Paul Ricoeur). Other themes concern the evaluation of the 'affective turn' in feminist studies, and different kinds of readings (ways of analysing one's object of study), and their ethics: close, surface, deep, (hyper)symptomatic, queer and descriptive ${ }^{1}$.

In the Introduction to the anthology Critique and Postcritique (2017) Elizabeth Anker and Rita Felski give a splendid overview and assessment of current academic debates on critique by examining three prevalent themes: affect, politics and methodology. Anker and Felski discuss alternative models for engaging with literary and cultural texts, paying special attention to the ideas of 'reparative reading' (Sedgwick 2003), 'surface reading' (Best \& Marcus 2009), and the 'descriptive turn' (Love 2010). Besides giving their account of such alternative forms and methods of reading, Anker and Felski remind us that rethinking critique can perhaps forge stronger links between the academic and non-academic worlds. This requires us to explore new ways, models and practices of reading, understanding the objects we research that are less bound to scepticism and suspicion and more willing to affirm positive, innovative, world-making aspects of literature and criticism.

In order to better understand the persistence of critique as an academic approach Anker and Felski attend to diagnostic, allegorical and self-reflexive aspects of critique. A tentative taxonomy of the various objections to critique is offered, ranging from the 'turn to affects' to the 'chronic negativity' of critique. They note the important divergence between those thinkers who salute the emphasis on new ways of reading as a way of breaking with sceptical modes of analysis and those who emphasise the close entwinement of power with affective life. They pay attention to the political stakes of the current reassessment of critique, thus if critique is political, what are its politics? Reminding us simultaneously of the fact that critique is no longer marginal in academia but part of the mainstream: 'it has become another familiar pedagogical tool and research method in the neoliberal university' (Anker \& Felski 2017: 13).

Besides the body of work that engages with critique within the fields of cultural studies, literary theory and the current debates within the humanities, there is a similar kind of diagnostic work being done focusing on question of matter, new materialism and ontology. This body of work has focused on shifting the perspective beyond overemphasising language, meaning and ideology. The debates around how to value the status of 'matter' and the 'biological' in feminist studies is one example of the thematic at hand but also of how the stories we tell matter. Reassessing our own narratives regarding feminist thought and knowledge production, its locations, geopolitical formations and situatedness, regardless of disciplinary identifications is another thematic that has become constitutive of the self-understanding of the field of feminist studies (Hemmings 2011, Wiegman 2012, Dahl et.al 2016). The logic that dominates here is that knowledge production is not only a process of content, but also a question of the power relations embedded in representation - who and what is included and excluded in the archives of feminist knowledge production? Defining Butler and Sedgwick as the foundational figures of queer studies has for example been questioned by scholars that provide us a different archive, turning to a genealogy of queer thinking that involves the intersections of race, class and sexuality beginning with James Baldwin in the 1960s (Hames-García 2011). Historicising knowledge, emphasising its performative effects and thus its politics, forms other 'habits' that structure both academic and non-academic feminist critical interventions.

We have chosen to focus on critique and epistemic habits in this issue in order to make visible ways in which we think about and do critique but also to highlight the habitual aspect of feminist criticism as an interdisciplinary activity. Calling for change in the name of critique that is justified by the political are not only ways in which we express how we envision social justice, these acts can also become self-explanatory gestures. For example, the ways in which we deal with issues of intersectionality, representation and identity politics often contain such gestures, a thematic that both Heather Love and Robyn Wiegman elaborate upon in the interviews of this Special Issue.

Indeed, looking at our methods of reading and analysing materials has been an important way of rethinking critique especially by scrutinising our tendencies to prefer certain interpretations over others (Wiegman \& Dean 2013). Structuring the debates on critique around what Robyn Wiegman describes as 'the imaginary of the political', the promises of delivering either critique in the mood and mode of suspicion or affirmation is another habit that interests us here (Wiegman 2012, see also the interview in this issue). As editors of this Feminist Encounters Special Issue we are delighted to be able to engage in these thought-provoking, timely and multifaceted discussions by focusing on what we have chosen to frame as 'epistemic habits'.

\section{Epistemic habits}

The debates mentioned above around critique, new reading modes and queer method testify to a growing awareness of some deep-rooted, well-established, and sometimes almost self-evident epistemic habits that reside within feminist thinking. Many of these epistemic habits are connected to ideas and understandings of critique and

\footnotetext{
${ }^{1}$ See among many publications about critique on a more general level, Butler (2001), Rogoff (2003), Latour (2004), Mouffe (2008), Raunig (2008), Dean \& Wiegman (2013), Wiegman (2014), Love (2015), Felski (2015); and about reading theories and alternative practices, Gallop (2000), Apter and Freedgood (2009), Best and Marcus (2009), Weed (2012), Moi (2017).
} 
of critical feminist thinking both in more mainstream feminist or activist contexts, as well as within academic feminism. One example is the emphasis on inclusive/universalist reasoning in spite of the continuing highlighting of the importance of differences and diversity of identities. Routine phrases concerning, for example, the habitual repetition of gender as performative without any further arguments or clarification, has, in spite of its position as profound feminist critique of other definitions of gender, changed the notion of gender performativity toward selfevident 'truth' (or truism), to somewhat of a cliché. Cliché, being a manifest form of language superseding meaning by social function caused by repetitive use, is, according to C. Namwali Serpell, characterised by avoidance of reflection (Serpell 2017: 163). This means that habit and critique are not necessarily in opposition to each other. However, by underlining the importance of attending to effects of clichés, Serpell sees possibilities for another kind of thinking: as the most habitual language, cliché releases the speaker or reader to concentrate on other matters. According to her we should see our clichés not as used-up but as useful for precisely critical reflection (ibid, 169, 177).

Another strand of criticism and perspective on our practices comes from feminist interventions into the tradition of ordinary language philosophy that centres its focus on language use, the ordinary and mundane, in order to argue for a radical and revolutionising intervention into current theoretical debates (Bauer et al. 2015, Moi 2017). By turning towards an understanding of language that focuses on our use of language (rather than a theoretical outlook on how language works), critique becomes a matter of rethinking our often too overtly linguistic conceptions of language, revealing an overemphasis on epistemology as one of our epistemic habits (see also the interview with Heather Love in this issue).

Hence, the questions that interest us in this Special Issue are:

- How critique is understood or defined or interrogated in connection to specific research problems?

- Is critique taken for granted, being in no need of special articulation because of its congruity with theory itself, and therefore with knowledge production as such?

- What is then at stake in the feminist politics of knowledge production when it comes to unravelling its epistemological foundations?

- How much of the habits we engage in are a product of the institutionalisation of academic feminism and its theoretical and philosophical legacies?

These were the basic questions and thoughts about the current state of academic feminism that inspired us to organise the symposium A Critique of Our Own: On the epistemic habits of academic feminism in 2016. ${ }^{2}$ The articles in this special issue are both rewritten symposium plenary papers and new and commissioned texts inspired by this special issue call for papers. The way we tell our stories matter. Our narratives perform their own kind of politics. Our practices of citation reveal our interests, commitments, but also our habits (Hemmings 2011, Hames-Garcia 2011). Feminist academic knowledge now forms a specific kind of archive that is both in the making, but also reflective of the history of academic feminism. In this Special Issue we have endeavoured to challenge the conventions of our own field and to problematise our own tacit knowledges.

\section{Reassessing turns as an epistemic habit}

One of the emerging habits in the aforementioned debates is the intensified focus on 'turns' despite the fact that 'turns' have been around for a while, at least since the postmodern turn in the 1980s (Barad 2007, Liljeström 2016). As Heather Love remarks in the interview for this issue, speaking of a turn gives us the impression of moving forward, turning a page, a new leaf. But while we might be inspired by the sensation of something 'new' and the different turns indeed keep us 'moving' intellectually, we also identify (old) habits that as routinised gestures sometimes also come to structure our approaches and discussions in a particular way. In this issue we want to focus on this tension between new emerging ways of thinking about method, reading and our epistemological presuppositions, while at the same time paying attention to precisely the habitual ways of thinking, reading and writing in the 'new'.

Although reassessive work (for example on the linguistic turn, new materialism, or posthumanist and humananimal studies) has been problematised because of the ways in which this work inevitably comes to construct particular dominant versions of theoretical developments, narratives or representations about the field (see for example Irni and Vuola in this issue) still remain a central practice within academic feminism. Critique, redescription and dismantling of oppositions, binaries, and particular representations can be said to constitute a methodological approach in the Deleuzian, new materialist and critical approaches to knowledge (see Kyrölä, Liu Xin and Rogowska \& Juleskjær in this issue). To participate in critique is thus essential to the self-understanding of what feminist academic work is - with its emergence from political activism and its critical relationship to academia - perhaps so crucial that even reassessive work ends up being critical according to all too familiar gestures.

\footnotetext{
2 The symposium was connected to the Academy of Finland research project Timelines of Academic Feminism in Finland, located
} at the University of Turku. www.utu.fi/en/units/hum/units/gender-studies/research/pages/taff.aspx 
When we define one of the epistemic gestures of feminist storytelling to be exactly a kind of reassessment or redescription of different theoretical and historical narratives, the question of how to think about feminist storytelling in an alternative mode actualises itself. Paying critical attention to the narratives that form the historiography of our work is a practice that is justified and demanded of us in the name of the political. Engaging with or within critique has largely been framed as a question of politics and knowledge and thus centred on the questions of political forms of knowledge production. The alternative, as the story goes, is to be not only naïve, but specifically, politically naïve (Dean \& Wiegman 2013, Felski 2015). The politicising of knowledge can thus be said to have become one of our main epistemic habits.

\section{Articles in the current issue}

This special issue opens with an article by Ellen Mortensen assessing Rita Felski's (2015) account of critique and her alternative postcritical position. Mortensen focuses on the question of mood and does this from the viewpoint of affirmative affective thinking, paying attention especially to the notion of mood within Deleuzian affect theory.

The next two articles give historical interpretations on the formation of feminist epistemologies. With a personal and autobiographical account, Nina Lykke's article concentrates on dis/identification, 'cruel optimism' and everyday utopianism as instances of feminist epistemic habits, but also as structuring themes for feminist thought. Elina Vuola also on her part engages in a re-reading of academic feminism, but from a very different point of view compared to Lykke: Vuola discusses the epistemic habit of exclusion within academic feminism focusing on religious feminisms. In Vuola's text the critique becomes 'cure', 'correcting' or reconstructing versions of a particular theoretical development.

Three articles deal with feminist epistemic habits of de/constructing dualisms. In order to problematise the binary between poststructuralist and new materialist feminist work, Sari Irni examines as her case study the history of steroid hormones, rethinking the relations between natural sciences and politics. She pays special attention to Helga Satzinger's (2012) 'politics of gender concepts' and suggests that in particular in relation to steroids a feminist critique is required which does not reproduce, but bridge the binary mentioned. Monika Rogowska-Stangret and Malou Juelskjær investigate temporalities and possibilities of thinking through new materialist theorising and concepts in order to examine conditions of the im/possibility of living live-able (learn-able, teach-able, and response-able) academic lives in current political climates. Addressing the temporal ontologies that drive and haunt university life, they deal with the notion of 'slowing down' as a response to the 'fast neoliberal university'. They make visible epistemic habits from the context of our everyday lives and practices and show the challenge in engaging in critique, proposing an ethics of a pace of our own.

The third text in the cluster of articles all engaging with the question of dualisms, is written by Liu Xin and deals with another set of binaries, namely both specificity and universality, and unity and plurality discussing especially the question of origin. Based on the (Irigarayan) idea of the impossibility of counting zero, Liu Xin suggests a form of feminist critique similar to what Trinh T. Minh-ha (2016) has named 'lovecidal'.

The last group of articles close in quite different ways around the question of feminist politics and knowledge production. Katariina Kyrölä investigates the knowledge of Black feminist thought in the music videos of Nicki Minaj and Beyoncé through the notion of disidentification, Kyrölä takes feminist criticism as her object in asking what kind of racialised, sexualised and gendered power relations and affects are articulated in the habit of asking: 'whether the videos and artists are - or are not - feminist or empowering'?

In their article about Valerie Solanas' controversial SCUM Manifesto, Salla Peltonen Mio Lindman and Sara Nyman and read the politics of philosophy as the grammar of patriarchy, claiming that the SCUM Manifesto text has critical, philosophical and political significance they also point to certain difficulties of judgement that characterise feminist and queer critique. Like Kyrölä also the authors of this article highlight the importance of asking 'non-habitual' questions, refusing to apply a 'hermeneutics of suspicion' in reading Solanas, but considering the Manifesto as a highly relevant, queer philosophical text.

In addition to the articles the special issue contains two separate interviews with Robyn Wiegman and Heather Love on current debates about critique and postcritique, addressing especially the question of epistemic habits. Assessing the state and status of critique in feminist, gender and queer studies Wiegman and Love both historicise and contextualise the ongoing debates. They address the impact of neoliberalism, and the changing academic practices, linking it to personal investments. Furthermore, they also reflect on the psychoanalytical and affective aspects of critique.

Considering habitual gestures and habits of feminist academic knowledge production, and the questions, reflections, viewpoints and thoughts expressed and discussed in the published texts, that we think are particularly important within current feminist analysis, we hope that this special issue contribute to the surely intensifying debate about contemporary critique/postcritique.

September 2017 


\section{REFERENCES}

Anker, E. and Felski, R. (2017). Introduction. In: E. Anker and R. Felski, eds., Critique and Postcritique (pp. 1-28). Durham: Duke University Press.

Apter, E. and Freedgood, E. (2009). Afterword. Representations, 108(Fall), 139-146.

Barad, K. (2007). Meeting the Universe Halfway. Quantum Physics and the Entanglement of Matter and Meaning. Durham: Duke University Press.

Bauer, N., Beckwith, S., Crary, A., Langier, S., Moi, T. and Zerilli, L. (2015). Introduction. New Literary History, 46(2), pp. v-xiii.

Best, S. and Marcus, S. (2009). Surface Reading: An Introduction. Representations, 108(Fall), pp. 1-21.

Butler, J. (2001). What is Critique? An Essay on Foucault's Virtue, Transversal Texts [online], transform.eipcp.net. Available at: http://transversal.at/transversal/0501 [Accessed 24 Jul. 2017].

Dahl, U., Liljeström, M. and Manns, U. (2016). The Geopolitics of Nordic and Russian Gender Research 1975-2005. Södertörn: Södertörn University.

Dean, T. and Wiegman, R. (2013). What Does Critique Want? A Critical Exchange. English Language Notes, 51(2), pp. 107-122.

Felski, R. (2015). The Limits of Critique. Chicago: The University of Chicago Press.

Gallop, J. (2000). The Ethics of Reading: Close Encounters. Journal of Curriculum Theorizing, 16(3), pp. 7-17.

Hames-García, M. (2011). Queer Theory revisited. In: M. Hames-García and E.J. Martínez, eds., Gay Latino studies: A critical reader (pp. 19-46). Durham, England: Duke University Press.

Haraway, D. (1988). Situated Knowledges: The Science question on feminism and the privilege of partial perspective. Feminist Studies, 14(3), pp. 575-599.

Hemmings, C. (2011). Why Stories Matter: The Political Grammar of Feminist Theory. Durham: Duke University Press.

Latour, B. (2004). Why Has Critique Run out of Steam? From Matters of Fact to Matters of Concern. Critical Inquiry, 30(2), pp. 225-248.

Liljeström, M. (2016). Affect. In: L. Disch and M. Hawksworth, eds., Oxford Handbook of Feminist Theory (pp. 1638). Oxford: Oxford University Press.

Love, H. (2010). Close but not deep: Literary ethics and the descriptive turn. New Literary History, 41(2), pp. 371391.

Love, H. (2015). Doing Being Deviant: Deviance Studies, Description, and the Queer Ordinary. Differences, 26(1), pp. 74-95.

Moi, T. (2017). The Revolution of the Ordinary. Chicago: The University of Chicago Press.

Mouffe, C. (2008). Critique as Counter-Hegemonic Intervention, Transversal Texts [online], transform.eipcp.net. Available at: http://transversal.at/transversal/0408 [Accessed 24 Jul. 2017].

Raunig, G. (2008). What is Critique? Suspension and Recomposition in Textual and Social Machines, Transversal Texts [online], transform.eipcp.net. Available at: http://transversal.at/transversal/0408 [Accessed 24 Jul. 2017].

Rogoff, I. (2003). From Criticism to Critique to Criticality, Transversal Texts [online], transform.eipcp.net. Available at: http://transversal.at/transversal/0103 [Accessed 24 July 2017].

Sedgwick, E.K. (2003). Paranoid Reading and Reparative Reading: or, You're So Paranoid, You Probably Think This Introduction Is about You. In: E.K. Sedgwick, ed., Touching Feeling: Affect, Pedagogy, Performativity (pp. 123151). Durham: Duke University Press.

Serpell, C.N. (2017). A Heap of Cliché. In: E. Anker and R. Felski, eds., Critique and Postcritique (pp. 153-182). Durham: Duke University Press.

Weed, E. (2012). The Way We Read Now. History of the Present: A Journal of Critical History, 2(1), pp. 95-106.

Wiegman, R. (2012). Object Lessons. Durham: Duke University Press.

Wiegman, R. (2014). The times we're in: Feminist criticism and the reparative 'turn'. Feminist Theory, 15(1), pp. 423.

Citation: Liljeström, M. and Peltonen, S. (2017). On Feminist Epistemic Habits and Critique. Feminist Encounters: A Journal of Critical Studies in Culture and Politics, 1(1), 01. https://doi.org/10.20897/femenc.201701

Copyright (c) 2017 by Author/s and Licensed by Lectito BV, Netherlands. This is an open access article distributed under the Creative Commons Attribution License which permits unrestricted use, distribution, and reproduction in any medium, provided the original work is properly cited. 
http://www.lectitopublishing.nl

https://www.facebook.com/LectitoJournals/

https://twitter.com/lectitojournals

$\mathcal{S}_{+}$https://plus.google.com/110901545130385419486

in https://www.linkedin.com/in/lectito-journals9a675010b/ 


\title{
Mood, Method and Affect: Current Shifts in Feminist Theory
}

\author{
Ellen Mortensen ${ }^{1 *}$
}

Published: October 30, 2017

\begin{abstract}
Epistemic habits in feminist research are constantly changing in scope and emphasis. One of the most striking ruptures that we can observe these days, at least in the humanities, is a renewed epistemic interest among feminists in the question of mood, where both positive and negative affects come into play. Mood figures in a number of theoretical traditions, ranging from the hermeneutics of Heidegger, Gadamer and Ricoeur, as well as in phenomenology, psychoanalytic theories of affect and in Deleuzian affect theory. In the article I want to explore two different approaches to the question of mood in feminist theory. In the first part, I will investigate Rita Felski's treatment of mood in her recent attack on 'critique' as well as in her proposed alternative, her 'post-critical' approach to reading and interpretation. In so doing, I will formulate some questions that have emerged in my attempt to grapple with Felski's post-critical approach. In the second part of this essay, I will delve into another understanding of the concept of mood, namely Deleuzian affect, and more specifically, as it has been embraced by feminist theorists such as Rosi Braidotti and Elizabeth Grosz in their respective theoretical works. In the concluding part of this article, I will discuss some of the implications of the different takes on mood for feminist epistemic habits.
\end{abstract}

Keywords: feminist theory, mood, method, Deleuzian affect

\section{The Malaise of Critique}

According to Rita Felski, we are witnessing a sea change in the way in which feminists approach the act of reading and interpretation, not only when it comes to the question of mood, but by implication, our understanding of method. In her paper, 'Identification: A Defense' (2016), Felski presents a bold line of argument, defending positive identification and affective attachment as a valid approach in reading and perceiving works of art. Her intervention is furthermore elaborated in her polemic book, The Limits of Critique (2015), where she attacks critique, while undertaking a detailed scrutiny of current interpretive practices of critique-which she claims has attained a hegemonic position in literary and cultural studies over the course of the last four decades.

Felski (2015: 1) challenges critique's claim to legitimacy and superiority based on an ethos of reading that demands negative affects, such as ironic detachment, disenchantment and the use of highly sophisticated strong theory; in short, a mood and method that embraces a hermeneutics of suspicion.' In addition, she casts doubt over critique's premise that these reading practices of soupcon are inherently more radical and subversive when it comes to the capacity to effect political and social changes, than other reading approaches do. According to Felski, the state of affairs is quite the contrary: critique constitutes today an 'anti-normative normativity' in feminist cultural studies, where most actors in the institutions are expected to perform readings in the mood of negativity, using methods of scrutiny that claim to unbind, unravel, demystify, de-familiarize, deconstruct and unveil oppressive power structures or regimes. Critique has, in Felski's assessment, become the dominant mood and method in these research fields today, and one would be hard put, she says, to argue that the critical style of thought represents a challenge to the institutions of power/knowledge today.

Rita Felski presents an unabashed defense of positive identification and calls for the re-valuation of positive affect of attachment in the aesthetic experience, which she posits as an antidote to the negative and melancholy mood at work in critique. Contrary to critique's skepticism and symptomatic reading strategy, Felski opts for an up-front and close-up scrutiny and a 'thick' description. She starts off with an examination of critique's use of 
rhetoric and form, affect and argument. She concludes that, as a distinct mode of interpretation, critique revels in dis-enchantment and ironic distance; it favours the archeological method, which requires that the critic 'delves deep' and 'stands back,' while mistrusting the text's surface level in order to wrestle from the text that which it allegedly attempts to withhold from its readers. Hence, Felski is able to identify, through her descriptive approach, what turns out to be 'a quite stable repertoire of stories, similies, tropes, verbal gambits and rhetorical ploys' (Felski 2015: 7).

Critique is thus approached as a genre and an ethos, and Felski regroups a vast range of interpretive strategies within this particular style of thought: symptomatic reading in general, be it Marxist ideology critique, psychoanalysis, deconstruction, Foucault's historicism, or any other reading approach which scans texts for signs of transgression or resistance; in short, every school of thought that has been embraced by feminists during the last three decades. Felski also includes what she calls a practice that she identifies as 'critique of critique,' referring to recent texts, such as Robyn Weigman and Elizabeth Wilson's essay on 'anti-normativity's queer conventions' (Felski 2015: 146).

Despite using a broad brush in her attempt to conjure up a picture of critique, Felski by and large gives a persuasive account of the practices of critique. She thus succeeds in showing not only the main characteristics in mood and method of critique, but in addition, that it is only one style of thought used in literary and cultural studies among many others, irrespective of its own attempt to appear as all-encompassing and without limit. Felski convincingly reveals that - contrary to its own ethos of impersonality, detachment and distance - critique has its own distinct affects, even if these are for the most part steeped in a negative mood of disenchantment, mistrust, melancholy and gloom. She is overtly skeptical towards critique's inflated belief in and claims to being inherently progressive or emancipatory, and she has grown weary of critical thought's claim to inherent radicalism. Likewise, she is critical of the inability of certain actors to acknowledge how feminist academics engaging in critique are implicated - and may well serve as complicit actors - in the workings of contemporary capitalism, both within and outside the academic institutions.

\section{Felski's Post-Critical Approach}

While aiming at challenging the hegemonic position of critique, Felski also proposes a distinct alternative to this style of thought. In so doing, she makes a concerted effort not to revert to critique herself in her own treatment of critique. Instead, she makes use of the phenomenological method of 'thick' description of critique as a distinct interpretive strategy. In part, she bases her account of critique on Eve Kosofsky Sedgwick's early intervention, 'Paranoid Reading and Reparative Reading' (Sedgwick 1997), where Sedgwick takes issue with the claims and mood of critique in an attack that was primarily aimed at Judith Butler. Sedgwick lists five characteristic traits of critique and labels them an instance of 'paranoid reading.' Felski both reiterates and elaborates these prominent traits ${ }^{1}$ in her own five-point description of critique in her book, where she lays out its rhetoric of 'standing back' and 'digging deep': 1. Critique is secondary 2. Critique is negative 3. Critique is intellectual 4. Critique comes from below 5. Critique does not tolerate rivals (Felski 2015: 121-150).

As an alternative, Felski calls for a reorientation and a re-description of the critical practices associated with the 'hermeneutics of suspicion,' in accordance with Paul Ricoeur's understanding when he coined the term, hailing Nietzsche, Freud and Marx as initiators of a new mode of interpretation (Ricoeur 1970). But according to Felski, Ricoeur paid close attention to the question of mood or attunement and insisted on the need to adopt a wide range of methodologies in the interpretation of works of art. Thus, in addition to a 'hermeneutics of suspicion,' he also called for a 'hermeneutics of trust or restoration.' This attention to diversity in moods and methods was not adopted or sanctioned by the feminist practitioners of critique, who according to Felski gave priority to disenchantment and suspicion (Felski 2015: 30-39).

Her approach to the study of literature is a set of reading practices, which draw on a number of different philosophical and theoretical traditions and movements. While arguing for a need for a reorientation and a redescription of what actually happens in critical reading practices, Felski wants to move away from negative aesthetics and instead orients herself towards what she calls relational ontologies. ${ }^{2}$ In this move, she merges diverse,

\footnotetext{
${ }^{1}$ Sedgwick's five points of paranoid reading are: 1) anticipatory; 2) reflexive and mimetic. 3) strong theory 4) a theory of negative affects 5) it places its faith in exposure (Sedgwick 2003, 130).

${ }^{2}$ By relational ontologies, Felski invokes Bruno Latour and his Actor-Network-Theory of ontological relations, which she formulates as follows: For Latour, by contrast, there is no historical box and no society, if we mean by this term a bounded totality governed by a predetermined set of structures and functions. Society does not stand behind and steer human practices, as if it were outside of and ontologically distinct from these practices, akin to a shadowy, all-seeing, puppet master. Rather, what Latour calls the social is just the act and the fact of association, the coming together of phenomena to create assemblages, affinities and networks (Felski 2015: 157).
} 
and one might suggest, perhaps incompatible human and non-human actors and practices. She coins a hybridity that she names a 'post-critical' approach, where we discern the following preferential attachments discussed below.

The first attachment that Felski makes in sketching out an alternative to critique is to the tradition of philosophical hermeneutics that pays heed to the notion of 'mood' as the tacit foundation of all interpretive acts. In her book (2015: 20), she makes an explicit reference to Martin Heidegger's thinking on 'Being-in-the-world' as 'Being-with,' notably as a mode of attunement, Stimmung (Heidegger 1962). In addition, Felski wants to retrieve that which the practitioners of critique have forgotten or overlooked in their appropriation of Paul Ricoeur's understanding of a 'hermeneutics of suspicion,' namely a 'hermeneutics of trust or of restoration' (Felski 2015: 32), which speaks of the more positive affects involved in the act of interpretation.

The second theoretical attachment that Felski establishes is to phenomenology, which among others attempts to establish the parameters of a first person, subject position. She distances herself from the Husserlian notion of radical reduction to a 'transcendental ego' (Husserl 2006), which is thought of as a disembodied entity, and prefers instead the casting of the first person as an embodied subject position, as it is formulated in the phenomenological and existential philosophy of Simone de Beauvoir (Beauvoir 1997) and later elaborated by Toril Moi (2001). According to Moi, Beauvoir's notion of existential situation is both a dimension of facticity and of freedom, projected onto the future, and can therefore never be reduced to a fixed essence or identity (2001: 65-66). Felski aligns herself with Moi's reading of Beauvoir, and understands the first person position as an embodied situation; one that accounts for the idiosyncratic, embodied style of the subject and for the sociality inherent in the horizon in which the situated subject dwells. Felski's call for a return to phenomenology and Moi's appropriation of Simone de Beauvoir is partly supplemented by other theorists, such as Chantal Mouffe, Marielle Macé and Yves Citton, who embrace aspects of pragmatism and ordinary life philosophy in order to formulate a positive theory of subjective reading that is grounded in lived existence and in embodied affects.

Felski also advocates for reviving the 'thick' descriptions that the method and practice of phenomenology provides when she calls for a more thorough and complex description of the phenomena of identification and attachment in reading practices. She supplements this phenomenological description with insights that the film critic Murray Smith (Smith 1995) introduced in his treatment of identification in film theory. Murray argues that the term identification ought to be divided into four different issues and experiences, namely alignment, allegiance, recognition and empathy. According to Felski, these four aspects are 'analytically and experientially distinct, though they can of course be combined' (Felski 2015: 8).

A third positive attachment that Felski makes in her delineation of an alternative to critique is to the work of Sedgwick, who introduced not only queer theory (together with figures such as Teresa de Lauretis and Judith Butler), but also the importance of affect in the act of reading literature. Sedgwick launched the notion of 'reparative' as opposed to 'paranoid' reading, terms that she retrieved from Melanie Klein (Klein 1998) and which she marshalled as an alternative to critique's symptomatic reading practices. Felski repeatedly refers to Sedgwick's contribution and values her emphasis on affect; she thus aligns herself with Sedgwick as well as queer theorists like Heather Love and Elizabeth Weed, who both welcome the inclusion of affect in interpretive practices. These queer theorists, as opposed to for example Judith Butler (Butler 1990), attest to the fact that not every scholar engaged in queer theory categorically embraces the mood of negativity, disenchantment and soupcon, but also love and joyful attachment. Accordingly, Felski includes them in her group of allies, in opposition to queer theorists such as Butler, Weigman and Wilson.

Felski's fourth attachment in fleshing out her 'post-critical' approach to literary and cultural studies is to the work of Bruno Latour and his Actor-Network-Theory, or ANT (Latour 2005). ANT alludes to the intricate network active in the ant hill, where every ant engages in a complex network connected to other ants, forming a special kind of sociality. Felski's interest in Latour is in part motivated by the fact that his network theory allows her to detect how critique as an ethos of reading is based on shared habits of thinking and established idioms. Hence, critique has succeeded in the building of an intellectual community and in establishing its own network of attachments, which has attained a hegemonic position in academe, especially in the U.S.

Furthermore, Latour's Actor-Network-Theory allows Felski to elaborate her own thinking on the practice of literary and cultural studies as a process that assembles a vast number of human and non-human actors, who through interaction and mutual negotiations form complex networks: 'scholars, computers, email-messages, journals, conferences syllabi; seminar rooms; monographs' (Felski 2015: 12). Felski agrees with Latour in that any kind of knowing is a 'mode of existence,' with its own 'vectors, orientations, chains of action and experience' (2015: 12). For her, reading literature is fundamentally a social enterprise, involving a complex network of actors, and can never be reduced to the reader-object dyad.

\section{Mood, Networks and Affect}

I find much of Felski's intervention both insightful and timely. That being said, I feel the need to question and challenge certain aspects of her proposed post-critical stance. First of all, I take issue with Felski's use of Heidegger 
and his ontological thinking on 'mood' as the basis for her re-thinking of affective identification. In Being and Time (Heidegger 1962), Heidegger carefully lays out, through his own version of a radical hermeneutics, the disclosure of Dasein's 'Being-in-the-world' as 'Being-with.' Heidegger's existential analytic is situated within his thinking on the hermeneutic circle, as the horizon into which we are all thrown, together with other beings. Dasein as a 'BeingTowards-Death,' experiences its ownmost Being in authenticity and fundamental precariousness in the loss of self, which causes fear and angst. This mood, the Stimmung of fearfulness and angst, occurs when Dasein falls out of the category of 'das Mann,' that is, a falling out of the subject position in ordinary language. Heidegger's Stimmung, which reveals itself in its authenticity when cast in the negative, constitutes the ontological experience of a loss of ground, when Dasein is most attuned towards Being. Attunement or mood, according to Heidegger, occurs prior to and is constitutive of interpretation, which is always thought as secondary or derivative (1962:172-182).

Interpretation, as an act performed by the subject, happens in an ontic position, that is, in Dasein's experience of inauthenticity. Ontic interpretation is thus dependent on and derivative of Stimmung, thought as an ontological mode of Being. My question to Felski is therefore: How can identification, which she understands as an affective orientation in the positive, find its basis in Heidegger's thinking on mood, attunement or Stimmung? In, Stimmung as an authentic ontological experience is an event through which Dasein finds its ownmost Being in the loss of ground, one that is steeped in angst and negativity. Furthermore, it is Heidegger who - prior to Ricoeur's coining of a 'hermeneutics of suspicion' - was perhaps the practitioner par excellence of critique and who lays the ground for the later hermeneutic thinking on soupson, be it in Gadamer or Ricoeur. In his symptomatic readings of the history of philosophy (in part inspired by and in opposed to Nietzsche's thinking on interpretation), it suffices to refer to his work on the Pre-Socratics (Heidegger 1975) as well as to his work on Kant (Heidegger 1997), where Heidegger claims to unveil in his reading that which is silenced and hidden in Kant's thinking. In Felski's own words, this is the essence of what the practice of critique entails, namely to unveil that which the text presumably withholds.

I agree with Felski that Stimmung occurs prior to and constitutes the basis for interpretation, but in Felski's recasting of identification as an affective orientation of the first person towards its object, Stimmung becomes a positive affect that is lodged within the subject-object parameter of ordinary language, which for Heidegger is nothing but 'idle talk.' Such an appropriation is far removed from Heidegger's thinking on authentic attunement or Stimmung, which he understands as an ontological mode of existence, in attunement to the groundless ground of Being. When Felski translates Stimmung into a positive affect that secures the subject's affective attachment and identification to an object, it amounts to a misappropriation of Heidegger's thinking, and may serve as yet another instance of metaphysical, ontic appropriation of his ontological thinking.

My next point of contention with Felski pertains to her advocacy for Latour's Actor-Network-Theory (ANT), which she wants to import into the practices of literary and cultural studies. Latour's theory of the workings of complex networks - real or virtual - in contemporary Western societies is both relevant and useful. Like many other social theories that have been adopted by literary studies, I truly believe that an attempt to integrate some of Latour's methods at detecting and creating a cartography of networks at work in the reception and interpretation of literature - involving human as well as non-human, real and imaginary actors - could prove fruitful for literary studies. However, Felski remains quite vague as to how these studies should actually be conducted, and what methodologies should be used. Her accounts of the salience of ANT in both her paper and in her book are at best vague and underdeveloped. It remains unclear in Felski's account how this theory may function as a reading strategy and a mode of literary analysis in literary studies.

Felski's understanding of the aesthetic experience pertains on the one hand to the first person singular; this position is marked by the affective idiosyncrasies of the subject. But in addition, the subject is a product of sociality, i.e. fabricated and co-produced, involving an intricate network of actors. A valid question in this context is whether or not affective identification in the first person as it is understood in phenomenology can be merged with Latour's understanding of agency within the actor-network. In my assessment, Latour's notion of agency, which includes human as well as non-human entities, is far removed from Beauvoir's phenomenological, embodied notion of the subject, not to mention Heidegger's thinking on attunement in the ontological disclosure of Dasein. Felski herself seems to ignore any possible problems in lumping these various theories together to form a first person foundation for her alternative reading strategy of 'positive identification.' Can we just infer from this account that identification will function in the same way when applied to collectives or networks of human and non-human actors, and how is this solved methodologically? These critical questions aside, I commend her intervention into the problem of critique by way of mood and positive affective identification in feminist theory. Felski raises important methodological and theoretical questions pertaining to our epistemic habits, and her call for a redirection in literary studies is both valid and persuasive. 


\section{Deleuze and Guattari on Affect}

Even though Felski's intervention into the shortcomings of critique might be instructive and valid, there is another school of feminist thinking on affirmative affect that I find even more compelling, namely one which is nourished by Deleuze and Guattari and the philosophical legacy of Spinoza, Nietzsche and Bergson. Felski by and large overlooks this theoretical branch of thinking on mood. Symptomatically, I have found but one brief reference in her book to Deleuze and Guattari, in a subordinate sentence where she disclaims the two French philosophers and their attack on what they call 'intepretosis' (Felski 2015: 10). Unlike Felski, feminist theorists such as Rosi Braidotti and Elizabeth Grosz embrace Deleuzian philosophy, which takes a radically different view on affect. Neither Braidotti nor Grosz can be subsumed under Felski's rubric of critique in the negative mood, since they both emphasize affirmation and positive affects in their critical practices. Even though they read Deleuze and Guattari in different ways, both Braidotti and Grosz import the French philosophers' understanding of affect into their own feminist theories.

In Deleuze and Guattari's philosophy of life and becoming, they attempt to circumvent the idealist and rational philosophical tradition from Plato through Hegel. Thus, they seek - in part through the legacy of Spinoza, Nietzsche and Bergson - to produce ways of doing philosophy that values life; not as stable identity, but life in its becoming. According to Deleuze and Guattari, philosophy and art may serve life in as much as philosophy creates life-enhancing concepts and art produces affects. Affect is for them not a subjective emotion or a personal inclination, but connotes instead 'the incredible feeling of an unknown Nature,' and they write:

For the affect is not a personal feeling, nor is it a characteristic; it is the effectuation of power of the pack that throws the self into upheaval and makes it reel. Who has not known the violence of these animal sequences, which uproot one from humanity, if only for an instant, making one scrape at one's bread like a rodent or giving one the yellow eyes of the feline? A fearsome involution calling us toward unheard-of becomings. (Deleuze and Guattari 1987: 240).

For Deleuze and Guattari, when speaking of affect, it is a question of a capacity to act and to create movement, marked by different levels and qualities of intensity (of power), as opposed to a specific entity that is quantitatively measured through representational language, as in traditional metaphysics. Thus, affect in Deleuzian-Guattarian terms is (following Spinoza) above all 'the capacity to affect and to be affected' (Deleuze and Guattari 1987: 261):

To every relation of movement and rest, speed and slowness grouping together an infinity of parts, there corresponds a degree of power. To the relations composing, decomposing, or modifying an individual there correspond intensities that affect it, augmenting or diminishing its power to act: these intensities come from external parts or from the individual's own parts. Affects are becomings (Deleuze and Guattari 1987: 256).

In the process of 'becoming intense,' which marks a process of deterritorialization in different stages, Deleuze and Guattari include the notion of 'becoming-woman' as a first and necessary stage. They thus acknowledge that the molar identity of 'man' is being invested with oppressive power, notably through the patriarchal-capitalist assemblage. Molar, masculine identity must therefore be de-territorialized on the plane of organization in order for life forces to be liberated, allowing for affects to circulate freely, which again might allow new becomings on the plane of consistency or immanence.

Affects, as intensive forces, are crucial for the capacity to act in order to undermine the stability of molar identities and their oppressive assemblages. Deleuze and Guattari thus propose diverse strategies of deterritorialization in order to undo the existing patriarchal gender and sexuality regime, which serves the interest of man in capitalist societies. In their material ontology, 'becoming-woman' is the first stage, and one that all processes of deterritorialization have to pass through. They ask:

Why are there so many becomings of woman, but no becoming-man? First, because man is majoritarian
par excellence, whereas becomings are minoritarian. (...) Majority implies a state of domination, not the
reverse. (...) In this sense, women, children, but also animals, plants, and molecules, are minoritarian.
It is perhaps the special situation of women in relation to the man-standard that accounts for the fact
that becomings, being minoritarian, always pass through a becoming-woman (1987: 291).

Affects mobilize all further processes of deterritorialization, which start with 'becoming-woman' and move via 'becoming-animal,' 'becoming-molecular' and finally reach, 'becoming-imperceptible,' which constitutes the final stage of deterritorialization on the plane of consistency or immanence, from whence new becomings may spring 
forth. Deleuze and Guattari advocate in this context for a continuous dynamic self-production of multiple sexes and poly-sexualities in the war machine against the tyranny of the molar identities of patriarchal-capitalist assemblages.

Feminism, for Deleuze and Guattari, is an ideology of fixed gender and sexuality categories. As such, feminism is implicated in this power dynamic, and may attribute to solidify power within this oppressive state of affairs. Feminist critique may therefore function as reactionary and reactive forces in capitalist society. Furthermore, when Deleuze and Guattari propose ways of undermining patriarchal, molar power regimes on the plane of organization, they advocate for a dynamic self-production of multiple, un-natural, perverse assemblages, where the human body enters into productive relations with other affective entities, e.g. human, animal, machinic or artificial entities in order to create 'unheard-of becomings.'

Art and literature constitute 'blocks of affect' for Deleuze and Guattari, and in their view, artistic practices are intensive, i.e. affective processes of deterritorialization. Mimetic art and literature written in representational language are accordingly deemed inferior forms of artistic productions; only when art produces 'unheard-of becomings,' affects with a capacity to create new becomings, can art and literature be said to be successful. In What Is Pbilosophy, Deleuze and Guattari (1994) ponder the specific transformative function of literature as affect:

The affect goes beyond affections no less than the percepts goes beyond perceptions. The affect is not the passage from one lived state to another but man's nonhuman becoming. (...) [B]ecoming is an extreme contiguity within coupling of two sensations without resemblance or, on the contrary, in the distance of a light that captures both of them in a single reflection. André Dhotel knew how to place his characters in strange plant-becomings. Becoming tree or aster: this is not the transformation of one into the other, he says, but something passing from one to the other. This something can be specified only as sensation. It is a zone of indetermination, of indiscernibility, as if things, beasts and persons (...) endlessly reach that point that immediately precedes their natural differentiation. This is what is called an affect (1994:173).

Affect in Deleuze and Guattari is therefore not connected to a subjective feeling or a personal inclination, but is rather a sensation that involves not only a subjectivity, but an affective field that connects the subject's body with other living and non-living force-fields, thus involving forces of cosmic implications.

\section{Rosi Braidotti's Affirmative Feminist Critique}

In her thinking, be it on the 'nomadic' (Braidotti 1994), 'monstrosity' (1996), the 'ethics of affirmation' (2006) or 'the posthuman' (2013), Rosi Braidotti embraces Deleuze and Guattari and their thinking on affect. Throughout the last three decades, she has consistently argued for an affirmative approach to feminist inquiries and feminism's ethical responses to the challenges of our times:

This sort of turning of the tide of negativity is the transformative process of achieving freedom of understanding through the awareness of our limits, of our bondage. This results in the freedom to affirm one's essence as joy, through encounters and minglings with other bodies, entities, beings, and forces. Ethics means faithfulness to this potentia, or the desire to become. Deleuze defines the latter with reference to Bergson's concept of "duration," thus proposing the notion of the subject as an entity that lasts, that endures sustainable changes and trans-formation and enacts them around him/herself in a community or collectivity. Affirmative ethics rests on the idea of sustainability as a principle of containment and tolerable development of a subject's resources, understood environmentally, affectively and cognitively (2006: 246).

Braidotti's repeated attempts to circumvent the pitfalls of negativity in her theorizing is founded on an ardent commitment to affirmative practices, where she pays heed to embodiment, sexual and racial difference, multicultural and post-secular citizenship, issues linked to globalization, network societies, contemporary art and technoscience. In Metamorphoses, Braidotti accordingly argues that Deleuze might prove productive for feminist thinking because he 'takes the plunge into the ruins of representation and the sensibility of the post-human' (2002: 97), and she writes:

He wants us to confront the kaleidoscope of affects and desires that one is deliberately not socialized into becoming. As a consequence, Deleuze's nomadology is not only conceptually charged, but also culturally very rich. In as much as he invests creativity with nomadic force, Deleuze raises issues of sensibility, affectivity and ultimately, desire. It is on this field, therefore, that his encounter with feminist allies is the most resoundingly vocal (2002: 97). 
Braidotti here attests to the fact that Deleuzian affect forms an integral part of her own feminist theoretical project, which attempts to align his affective thinking with a host of other feminist thinkers, above all Irigaray and Haraway, in order to vitalize the field of feminist theory. She writes:

Deleuze redefines the practice of theory-making in terms of flows of affects, and the capacity to draw connections. Accordingly, Deleuze describes the subject as an affective or intensive entity and ideas as events, active states which open up unexpected possibilities of life. The truth of an idea, in other words, is in the kind of affects and the level of intensity that it releases. (...) Affectivity governs the truth-value of an idea. In juxtaposition with the linear, self-reflexive mode of thought that is favored by phallogocentrism, Deleuze defines this new style of thought as 'rhizomatic' or 'molecular.' These new figurations of the activity of thinking are chosen for their capacity to suggest web-like interactions and interconnectedness, as opposed to vertical distinctions. Deleuze defends this view of the subject as a flux of successive becomings by positing the notion of a 'minority' consciousness, of which the 'becoming-woman' is somehow emblematic (2002: 70).

In making active use of Deleuze and Guattari's notion of affect as a vital and creative force in feminist theorymaking, Braidotti usurps feminist theory's traditional reliance on rational and representational, reflexive models of thought. As such, Braidotti's understanding of affirmative affects differs radically from Felski's in that she does not approach the question of mood through the framework of phenomenology - such as an embodied individual subject or a social collective of agents - but rather as an ontological, collective flow or force at work in and through the subject or the collective. Furthermore, whereas Felski relies on a mimetic and a realist, descriptive mode of representation in her affective theorizing, Braidotti stresses the rhizomatic, deterritorializing, unpredictable and 'monstrous' couplings that may emerge in affective assemblages, effects of which by far exceed the control of the interpretative subject or its social network.

\section{Elizabeth Grosz: Art as Affect}

Another feminist theorist who finds great inspiration in Deleuze and Guattari's thinking on affect is Elizabeth Grosz. Throughout most of her work from the last thirty years, she delves into the thinking of Deleuze and Guattari and its relevance for feminist thought. Likewise, in her book Chaos, Territory, Art (Grosz 2008) Grosz explores, among others, the interconnections between art and affect. Citing Deleuze, Grosz claims that art 'is of the animal,' and she writes:

Art, according to Deleuze, does not produce concepts, though it does address problems and provocations. It produces sensations, affects, intensities as its mode of addressing problems, which sometimes aligns with and link to concepts, the object of philosophical production, which are how philosophy deals with problems. (Grosz 2008: 10)

Grosz follows Deleuze in his defense of art as affirmative and life-enhancing and like him, she denounces the representational aspects of art. Instead, she emphasizes art as 'the art of affect,' that is, 'a system of dynamized and impacting forces,' with a capacity to produce and generate intensity, 'which directly impacts the nervous system and intensifies sensation' (2008: 12). Art is connected to the forces in nature, which are at work in human and animal bodies, in the earth and in the universe at large.

In a footnote, Grosz clarifies her understanding of affects as opposed to the phenomenological notion of lived experience:

Sensations, affects, intensities, while not readily identifiable, are clearly closely connected with forces, and particularly bodily forces, and their qualitative transformations. What differentiates them from experience, or from any phenomenological framework, is that they link the lived or phenomenological body with cosmological forces, forces of the outside, that the body itself can never experience directly. Affects and intensities attest to the body's immersion and participation in nature, chaos, materiality (2008: 12).

Art as affect or intensities is thus cosmically connected to forces that exceed human beings, individual bodies or human subjectivities. There is something inhuman in art that is produced through human creativity, and it is this affective aspect of art that is of interest to Grosz, as it is to Deleuze and Guattari. Art, through the plane of composition, which it casts, is 'the way that the universe most intensifies life, enervates organs, mobilizes forces (2008: 33). And according to Grosz, what philosophy and art have in common is 'their capacity to enlarge the universe by enabling its potential to be otherwise, to be framed through concepts and affects' $(2008,33)$. These capacities are to her among 'the most forceful ways in which culture generates a small space of chaos within chaos where chaos can be elaborated, felt, thought' (2008: 33). 


\section{CONCLUSION}

In this article, I have tried to account for the way that the question of mood constitutes a central concern, not only in Felski's attack on critique as a genre and ethos, but also that the concept plays a vital part in her proposed 'post-critical' approach, which she launches as an alternative to critique in the practice of interpretation. And, having formulated some critical questions and comments, above all in regards to her appropriation of Heidegger's understanding of Stimmung or attunement, I have, in the second part of this article, introduced another theoretical approach to the concept of mood, thought as affect, as it appears in the philosophy of Deleuze and Guattari. Subsequently, I have shown how this notion of affect has been embraced by both Braidotti and Grosz in their feminist theories. As I have noted, there are marked differences in the way Felski, Braidotti and Grosz approach and use the concept of mood in their respective theorizing, and accordingly, these different approaches generate different methodological and epistemological questions and implications for feminist epistemic habits.

Despite the problems and questions that I have articulated in relation to Felski's denouncement of critique, I remain sympathetic to her theoretical intervention and her advocacy for positive identification in her post-critical approach. I value her effort to create a debate; not only in gender studies, but also in literary studies and cultural studies more broadly. Felski's polemic position forces us to reflect on our moods and methods of interpretive scholarship and the affects that govern our orientations. Her expressed aim is to re-describe and reorient critical and interpretive practices in such a way that interpretation no longer exclusively pursues negative inquiries in the mode of a 'hermeneutics of suspicion.' In her view, the most salient approach to interpretation must also include a 'hermeneutic of trust or restoration.' As such, she not only pays heed to Ricoeur and Sedgwick's demand for greater complexity in the appropriation of mood, method and affect in the interpretive enterprise, but also acknowledges that parts of the critical heritage in critique will and may be restored through her new 'post-critical' approach.

The practice of reading and interpretation remains a major concern in any feminist scholarship, and the methods and affects that inform these practices ought to be continually questioned. For this effort Felski should be thanked, whether or not we support her arguments or question her assumptions and conclusions. However, Felski rarely, if ever, mentions Deleuzian affect theory, nor does she include any references to the host of theorists - non-feminist, feminist and queer theorists alike - who find great inspiration in Deleuze and Guattari's work on affect. Even if she does not agree with them, it would have been of interest to many had she engaged with some of these scholars of affect studies, since they have already made a great impact on literary studies as well as cultural studies at most institutions in the U.S. and Europe.

Neither Braidotti's nor Grosz' approach to the question of mood, using Deleuze and Guattari's notion of affect, can be subsumed under Felski's understanding of critique, performed in the negative mood. Their Deleuzian theorizing represents important theoretical practices within feminist theory today. In addition to these two, suffice it to mention some of the most influential feminist theorists today, who likewise mobilize a Deleuzian framework in their respective works: Tamsin Lorraine (1999), Jasbir Puar (2007) Claire Colebrook (2012), Patricia Ticineto Clough (2010) and Dorothea Olkowski (2014).

Rosi Braidotti, for her part, practices an affirmative approach to feminist theorizing and in so doing, provides important correctives to Felski's somewhat categorical denouncement of critique. Braidotti's nomadic understanding of the subject furnishes new insights into the complexities of agency and the differentiated and affective assemblages and networks into which the feminist subject is implicated in the age of techno-science. Elizabeth Grosz' Deleuzian approach to art as affect introduces yet another radically different approach than Felski's phenomenological approach to the aesthetic experience. Both Braidotti and Grosz' respective Deleuzian takes on mood as affect raises different questions, with important implications for feminist epistemic practices.

For one, it raises the question of whether or not it is sufficient to cast the subject in terms of a phenomenological framework (be it within the mood of soupcon or restoration) when accounting for the complex webs of interconnections and assemblages that the subject are affected by in the age of technology. And we may ask if it is possible, without difficulty, to merge phenomenological methods and concepts with Heidegger's existential hermeneutics and Latour's Actor-Network-Theory?

I would also be curious as to how the theories of Latour and Deleuze could be productively thought together. Even if they are engaged in different projects using different methods, would it not be interesting to explore Deleuze's thinking on affect and the emergence of rhizomic networks in relation to Latour's theories of orientations and actor network? Furthermore, I would be interested in pursuing an exploration of how identification might be thought in terms of affirmative affect in a Nietzschean-Deleuzian sense.

The feminist treatment of mood, method and affect is, needless to say, to be continued. New and unpredictable interventions will undoubtedly occur, hopefully bringing new questions and challenges into the debate, which will affect the epistemic habits in feminist theory - be it affirmatively or negatively - in the time to come. 


\section{REFERENCES}

Beauvoir, S. (1997). The Second Sex. Trans. H.M. Parshley. London: Vintage.

Braidotti, R. (1996). Signs of Wonder and Traces of Doubt: On Terratology and Embodied Differences. In: R. Braidotti and N. Lykke, eds., Between Monsters, Goddesses and Cyborgs (pp. 135-152). London: Zed Books.

Braidotti, R. (2002). Metamorphoses: Towards A Materialist Theory of Becoming. Cambridge: Polity Press.

Braidotti, R. (2006). Affirmation versus Vulnerability: On Contemporary Ethical Debates. Symposium: Canadian Journal of Continental Philosophy, 10(1), pp. 235-254. https:/ / doi.org/10.5840/symposium200610117

Braidotti, R. (2013). The Posthuman. Cambridge: Polity Press.

Butler, J. (1990). Gender Trouble: Feminism and the Subversion of Identity. London: Routledge.

Clough, P.T. (2010). The Affective Turn: Political Economy, Biomedia, and Bodies. In: M. Gregg and G.J. Seighworth, eds., The Affect Theory Reader (pp. 206-228). Durham: Duke University Press.

Colebrook, C. (2012). Blake, Deleurian Aesthetics and the Digital. London: Bloomsbury Academic Press.

Deleuze, G. and Guattari, F. (1987). A Thousand Plateaux: Capitalism and Schirophrenia. Trans. B. Massumi. Minneapolis: University of Minnesota Press.

Deleuze, G. and Guattari, F. (1994). What Is Philosophy? Trans. H. Tomlinson and G. Burchell. New York: Columbia University Press.

Felski. R. (2015). The Limits of Critique. Chicago: Chicago University Press.

Felski. R. (2016). Identification: A Defense. Proceedings of A Critique of Our Own: On the Epistemic Habits of Academic Feminism, University of Turku, April 14-16, 2016.

Grosz, E. (2008). Chaos, Territory, Art: Delenze and the Framing of the Earth. New York: Columbia University Press.

Heidegger, M. (1962). Being and Time. Trans. J. Macquarrie and E. Robinson. New York: Harper and Row.

Heidegger, M. (1975). Early Greek Thinking. Trans. D.F. Krell and F.A. Capuzzi. San Francisco: Harper.

Heidegger, M. (1997). Kant and the Problem of Metaphysics. Trans. R. Taft, 5th edition. Bloomington: Indiana University Press.

Husserl, E. (2006). The Idea of Phenomenology. Trans. W.P. Alston. Dordrecht: Kluwer Academic Publisher.

Klein, M. (1998). Love, Guilt and Reparation. London: Vintage.

Latour, B. (2005). Reassembling the Social: An Introduction to Actor-Network-Theory. Oxford: Oxford University Press.

Lorraine, T. (1999). Irigaray and Deleuze: Experiments in Visceral Philosophy. Ithaca: Cornell University Press.

Moi, T. (2001). What Is a Woman? And Other Essays. Oxford: Oxford University Press.

Olkowski, D. (2014). Birth in Beauty and the Power of Sensation. In: A. Calcagno, J. Vernon and S.G. Lofts, eds., Intensities and Lines of Flight: Deleure and Guattari and the Arts (pp. 97-110). London/New York: Rowman \& Littlefield.

Puar, J. (2007). Terrorist Assemblages: Homonationalism in Queer Times. Durham: Duke University Press.

Ricoeur, P. (1979). Freud and Philosophy: An Essay on Interpretation. Trans. D. Savage. New Haven: Yale University Press.

Sedgwick, E.K. (1997). Paranoid Reading and Reparative Reading. In E.K. Sedgwick, ed., Novel Gazing: Queer Readings in Fiction (pp. 1-40). Durham: Duke University Press.

Sedgwick, E.K. (2003). Touching Feeling: Affect, Pedagogy, Performativity. Durham: Duke University Press.

Smith, M. (1995). Engaging Characters: Fiction, Emotion, and the Cinema. Oxford: Clarendon Press.

Citation: Mortensen, E. (2017). Mood, Method and Affect: Current Shifts in Feminist Theory. Feminist Encounters: A Journal of Critical Studies in Culture and Politics, 1(1), 02. https://doi.org/10.20897/femenc.201702

Copyright (C) 2017 by Author/s and Licensed by Lectito BV, Netherlands. This is an open access article distributed under the Creative Commons Attribution License which permits unrestricted use, distribution, and reproduction in any medium, provided the original work is properly cited. 
http://www.lectitopublishing.nl

https://www.facebook.com/LectitoJournals/

https://twitter.com/lectitojournals

$\mathcal{S}_{+}$https://plus.google.com/110901545130385419486

in https://www.linkedin.com/in/lectito-journals9a675010b/ 


\title{
Academic Feminisms: Between Disidentification, Messy Everyday Utopianism, and Cruel Optimism
}

\author{
Nina Lykke ${ }^{1 *}$
}

Published: October 30, 2017

\begin{abstract}
This article reviews current debates on epistemic habits of critique and affirmation, specifically focusing on approaches which combine criticality with ways to encourage unfoldings of alternative futurities, figurations and worlding practices. Embedded in a process of critical self-reflection regarding epistemic habits, the article discusses disidentification (Butler 1993, Muñoz 1999), cruel optimism (Berlant 2011), and everyday utopianism (Cooper 2014) understood as examples of such habits. The article explores how feminisms, unfolding within academia, and thus institutionally embedded in the logics of global capitalism, neoliberalism and particular nation-state politics, on the one the hand, are bound to a performance of cruel optimism, glossing over dilemmas and contradictions, and, on the other hand, perhaps enabled to enact messy kinds of everyday utopianism. Finally, the article reflects upon possibilities for changing one's epistemic habits, suggesting a couple of changes: to systematically integrate reflections on changing conditions of academic knowledge production, as well as on geopolitical grammars. These issues are addressed as being interwoven with and mixed up in the epistemic practices that are produced by messy links with both feminist activist resistance and institutionalized and professionalized academic feminisms.
\end{abstract}

Keywords: academic feminisms, disidentification, cruel optimism, everyday utopianism

\section{INTRODUCTION}

In this article ${ }^{1}$, I shall draw a personalized cartography of some epistemic habits regarding critique and affirmation in academic feminisms ${ }^{2}$. I shall focus on intertwined habits of disidentification, everyday utopianism, and cruel optimism. I consider these two first mentioned epistemic habits to have emerged out of academic feminisms' reliance on and emergence from feminist movements of protest. However, the third item in my cartography, cruel optimisms, will be discussed as interwoven with the institutionalization of academic feminisms within neoliberalized universities, and with the ensuing process of becoming disciplined in order to comply with neoliberal, capitalist governmentality and with different nation-state goals embodied by state universities.

Critical scrutiny of the academic habits of critical intellectuals, academic feminists included, seems to be urgent against the background of present-day academic conditions and political climates. Conditions for performing academic work, and for making a living as a critical intellectual, are becoming more and more subsumed by global trends of neoliberal commercialization and streamlining of academic education and knowledge production (Forstorp and Mellström 2013), even though national university systems have responded, and sometimes tried to resist the trend in uneven ways, depending on unequal geopolitical situations. These conditions will inevitably have

\footnotetext{
${ }^{1}$ I thank Dr. Elizabeth Sourbut for linguistic revision of the manuscript.

${ }^{2}$ I use the term academic feminism to refer to multiple types of theorizing, researching and teaching, which have managed to establish platforms in universities and academic institutions in many countries during the past four decades. I consider these kinds of academic theory and practice as having been established with a basis in links to political activism outside of the academy, but also as a result of activism within the academy. I understand the relationship with multiple kinds of feminist political activism (anti-racist, queer of colour, crip queer, trans, ecological, decolonial, postsocialist etc.) as a sine qua non for these academic endeavours.
} 
an impact on epistemic habits, and so will the need to counteract right wing agendas, which both in Europe and in the US are denying effects of climate change, and promoting xenophobic, racist, transphobic, anti-queer, antifeminist views, while at the same time excelling in homo-nationalism (Puar 2007), as well as in what can be defined as (gender)equality-nationalism (Martinsson, Griffin and Nygren 2016). But, as Bruno Latour, pointed out more than a decade ago (2004), well-established critical tools are not necessarily apt for navigating in these waters. According to Latour, some kinds of critique, for example, critical constructionism, which has been a hallmark of some kinds of leftist critiques, including some feminist ones, seem to 'run out of steam' (Latour 2004: 245), when confronted with massive amounts of 'fake news' and climate change denial. Other kinds of Western leftist and feminist critiques have found themselves caught up in epistemologies of ignorance (Sullivan and Tuana 2007), when confronted with decolonial, anti-racist and posthuman critiques (Spivak 2003; Chow 2006; Lionnet and Shih 2011; Tlostanova and Mignolo 2012; Haraway 2016), which pinpoint how, at the outset, humanities and social science disciplines, inter- and sub-disciplines, on which much critical intellectual work has been grounded, are blinded by tunnel visions as far as issues such as structural whiteness or beliefs in human exceptionalism are concerned.

Against this background, it seems timely, as suggested by the editors of this special issue, to review epistemic habits, which often are implicitly given rather than explicitly discussed. I shall try to contribute to this endeavour, taking a critical look at epistemic habits which have been important in my work as an academic feminist, located in the Northern region of Europe (Sweden and Denmark), and with longstanding and in-depth collaborative relations to feminist colleagues in other European countries (South, East and West), as well as to broader global constituencies of feminist scholars.

Firstly, I shall situate myself, accounting for my academic feminist practices which have formed my views and entry points to this reflection on epistemic habits. Secondly, I shall reflect upon the epistemic habits of disidentification (Butler 1993; Muñoz 1999) and everyday utopianism (Cooper 2014), embedded in the process of critical, but also affirmative, self-reflection to which I have been committed in my own academic and other activist feminist practices. Thirdly, I shall discuss the extent to which feminisms, unfolding within academic institutions, pervaded by the logics of global capitalism, including the neoliberalization and commercialization of knowledge production, as well as particular nation-state politics, are also bound to a performance of cruel optimism (Berlant 2011), which glosses over dilemmas and contradictions, reproducing epistemologies of ignorance. Fourthly, I shall reflect upon possibilities for changing one's epistemic habits, and advocate some changes.

\section{SITUATING MYSELF}

Assessed from a retrospective, genealogical perspective, the three habits of disidentification, everyday utopianism and cruel optimism, have been crucial to my trajectory as an academic feminist.

The epistemic habits of disidentification and everyday utopianism combine criticality with a quest for ways to affirmatively develop alternative futurities, figurations and worlding practices. This combination of critique and affirmation is what attracted me to feminism in the first place, around 45 years ago, in the shape of radical, anticapitalist feminism that emerged in tandem with the Western European and North American students' revolts of 1968. Although rather differently theorized today, this combination is still the reason why I see a plurality of feminisms, academic feminisms included, as embodying important societal forces, committed in multiple ways to a critical fostering of promising new figurations and worlding practices.

However, seen in retrospective, I must admit that the epistemic habit of cruel optimism has also been part of my trajectory from the early 1980s, when I hesitantly decided to take my commitment to socialist-feminist activism from the movement outside of academia to bear on transformatory work within academia, following the students' movement slogan from back then about the 'long march through the institutions' (Dutschke 1980).

So let me briefly describe this 'long march' to make the situated background of my reflections on epistemic habits more transparent.

I have for decades been involved in the building of feminist environments and institutions in academic settings in Scandinavia, but also in the broader European arena. Since the early 1980s, I have participated in the building of feminist research and educational programmes in Denmark and Sweden. For almost two decades in the 1990s and 2000s, I was also active in broad European curriculum development projects. Additionally, I have directed international research training schools in interdisciplinary gender studies, including a Nordic school with 40 partner universities from the five Nordic countries as well as from Russia, the Baltic States, Poland and The Netherlands.

Against a background of continuous collective, cross-border and cross-institutional reflections on these longstanding practices regarding the building of feminist institutions at different kinds of European universities, those of us who were engaged jointly in these activities became more and more aware of the possibility of contradictory and messy alliances which were necessary in order to make faculty boards and other university authorities authorize the funding of feminist research and study programmes and units. To a certain extent, it also 
became clear that such alliances, in particular, could be made within the framework of neoliberalized universities. Through these year-long discussions and practices, I learned about twisting neoliberal university agendas and making a feminist difference, performing what I came to name 'feminist hit-and-run-interventions' in academic institutions. In particular, I learned a lot, while comparing notes on university structures throughout Europe. Through this work, I came to understand how feminist colleagues, engaged in struggles to set up feminist teaching and research programmes in universities, which still had not become fully neoliberalized (i.e. universities which were still trying to hold on to 'old' academic degree systems), had sometimes harder struggles to fight than those who worked in more neoliberal environments.

Feminist teaching and research programmes were established faster and more smoothly in countries such as the UK and Sweden - countries in which universities became subsumed under neoliberal trends earlier than was the case in many other European countries. By contrast, such programmes had more difficulties in gaining footholds in countries such as Italy, Germany, and Denmark that kept up 'Bildungs'-traditions [learnednesstraditions] for longer, guarded by professors who considered themselves above such 'low and base' things as neoliberal knowledge commercialization and packaging of education in 'small' modulized building blocks such as separate bachelor's, master's and $\mathrm{PhD}$ degree programmes.

I know both the old and the new system from 'inside'. On the one hand, my academic degrees are products of the old European degree system, which, in my native country, Denmark, was still in place when I was a student and young scholar. These are degrees whose format and content are impossible to translate into the neoliberalized system. On the other hand, I have directed feminist research and study programmes in early neoliberalized Sweden for many years. Therefore, I immediately understood why it was so difficult for academic feminist colleagues in European countries with not yet fully neoliberalized university systems to establish platforms for feminist research and education. By contrast to the old system's massively long degrees, the neoliberalized university's small modules, handily packaged to be sold and to attract a diverse body of students in competition with other universities worldwide, could more easily be transformed into 'Gender Studies modules'. The Gender Studies modules were just one among many other small components in the neoliberalized university, and the administrators in charge of the new kinds of modulized educations cared more about numbers and formalized rules for accreditation than about ideologies about specific norms of learnedness. In this way, messy alliances and loopholes for feminist teaching programmes which also sustained feminist research endeavours could be created.

\section{CRITICALLY DISIDENTIFICATORY WORLDING PRACTICES}

I shall start my cartographic exploration of the interwoven epistemic habits of academic feminisms in which I have been immersed with the notion of disidentification (Butler 1993). Although it is located within different theoretical and political frameworks, giving different meanings to the concept, 'disidentification' is conceptualized as a subject position located in-between identification and counter-identification (the latter understood as active non-identification). I have discussed this in more detail elsewhere (Lykke 2014). Therefore, I shall not dwell on different definitions, but turn to Judith Butler's take on political disidentification (1993). Butler discusses how imagined political communities gathering under the banner of a unifying category (e.g. 'woman' or 'queer') must always fail to establish the unity which the signifier seems to promise. The performative political signifier can never capture the complex web of intersectional social relations in which the community's participants are always already embedded. According to Butler, participants will always be socioculturally more diverse than the singular category under which they organize. Some dimensions of the participants' diversity will always be excluded by the unifying signifier.

The consequences of the necessary failure of the unifying signifier are profound. The movement's participants commit themselves because they are drawn in by the unity which the signifier promises. But when the signifier inevitably fails to keep its promise, it leaves the participants with an 'uneasy sense of standing under a sign to which one does and does not belong' (Butler 1993: 219). According to Butler, the unease generated by the situation, produces disidentification, i.e. ambivalent feelings of simultaneously belonging and not-belonging. Even though this can lead to frustration and immobilization, Butler also hopefully asks about 'the possibilities of politicizing disidentification', suggesting that 'the failure of identification' can become 'the point of departure for a more democratizing affirmation of internal difference' (Butler 1993: 219).

I claim that Butler's analysis of political disidentification is important not only in relation to an understanding of social movements, but also for a discussion of epistemic habits of academic feminisms. This claim is motivated by the ways in which academic feminisms are related to feminist movements and often considered to be identity studies' (Wiegman 2012). On this basis, I find it reasonable to understand academic feminisms as embedded in patterns of disidentification. I have discussed elsewhere (Lykke 2014) how moments in the history of academic feminisms when disidentifications have become outspoken, have worked productively to prompt ground-breaking 
new scholarly-political work. But I also claim more generally that disidentification makes up an important epistemic habit of academic feminisms, having critical as well as affirmative potential.

To illustrate how disidentification can work in an academic context, I shall provide an ultrashort overview of my own scholarly work, read through the lens of disidentification.

When I look back at my academic and activist trajectory from the 1970s until now, with disidentification as a genealogical lens, the concept fits well. In hindsight, I seem almost always to have been prompted to theorize and write feminist theory in a passionate mood of disidentification. I have often started out with an embodied feeling of unease about the theoretical discourses that were popular in the academic and political communities to which I belonged. This was despite the fact that, like many other students and researchers, I felt attracted to them due to the explanatory power they seemed to hold in terms of giving plausible and critical theoretical accounts of power differentials, which appeared to be important. Nevertheless, I felt that these attractive theoretical frameworks lacked an understanding of other intersecting power differentials that to me were also important.

I started publishing in the mid-1970s - during the heyday of feminist and psychoanalytical Marxism. Along with other socialist feminists from the recently launched 'new' women's movement, I began my academic career back then as a critical socialist feminist intellectual, disidentifying with the Marxist focus on class relations that failed to take intersections of gender and class thoroughly into account. This disidentification led me to contribute to feminist Marxist theorizing of power differentials based on intersections of gender and class (Lykke 1993).

I also disidentified with the 'heteropatriarchal' analysis of subjectivities that I frequently saw being uncritically reproduced even in feminist research. Taking my point of departure in this disidentification, I conducted a queerlesbian-feminist-Marxist de- and reconstructive reading of the Freudian theory of femininity (Lykke 1993). I spent most of the 1980s on this part of my disidentification, carving out genealogies of lesbian desire, along with queer masculinities and femininities.

During the 1990s, I brought my disidentificatory approach to bear on the anthropocentric focus on human affairs in much feminist theory and politics. In this respect, I have contributed to the inclusion of cyborgs, 'earth others' (Plumwood 1993) and other non-human agencies in the discussion of the intersecting power differentials that need to be taken into account in feminist theorizing and politics (Bryld and Lykke 2000). This part of my disidentificatory research was carried out in collaboration with my lifepartner, Mette Bryld (who sadly passed away in 2014), who was a feminist scholar of Russian studies. Our joint research also included a disidentification with the methodological nationalism that characterized Nordic feminist research at the time. Our focus was a critical scrutiny of the re-enactment of colonialist discourses vis-à-vis the classic trinity, woman-native-nature in Russian and US post-WWII discourses.

Along with other post- and transdisciplinary feminists, I have also disidentified with endeavours to anchor feminist research exclusively within the frameworks of specific disciplines. Both theoretically and politically, I have tried to resist the policing power of disciplines, carving out spaces for the development of feminist research and teaching as the oxymoron of a postdisciplinary discipline (Lykke 2010). These and the other disidentifications which have characterized my life as a critical feminist intellectual have been extremely productive for my research processes.

To wrap up this personal example: I consider theoretical disidentifications in academic feminisms to be productive in terms of generating new theoretical frameworks. Moreover I see them as resonating with political disidentifications taking place in the contexts of social movements.

Against this background, I shall provide a slightly more elaborate framing of my take on disidentification as an epistemic habit of academic feminisms, closely related to activist practices directed towards change. To do so, I shall add that, alongside Butler's definition of political disidentification, an important inspiration for my reflections is the discussion of the concept framed by queer of colour scholar José Esteban Muñoz (1999). Muñoz presents the concept of disidentification in relation to queer of colour performance art. I find Muñoz' theoretical framing of disidentification, indebted not only to Butler, but also to Chicana feminists (Alarcón 1991; Sandoval 2000), useful for theorizing an important combination of criticality and new affirmative worlding practices. I see these as crucial for understanding the epistemic habit of disidentification, which I consider to be a key component of much feminism, academic feminisms included.

I also find it important that Muñoz' conceptualization of disidentification and his emphasis on the ways in which the notion combines criticality and affirmativity resonates with, but also cuts through, the divide between a hermeneutics of suspicion/paranoid readings and reparative readings. As suggested by Eve Kosofsky Sedgwick (2003), this has become a popular tool in some academic feminist circles for moving beyond merely negative modes of critique. There are resonances between Muñoz' and Sedgwick's frameworks in terms of their transgressions of such negative modes. However, Sedgwick's framing is somewhat haunted by the logics it seeks to overcome. Sustained by the work of psychoanalyst Melanie Klein (1988), Sedgwick struggles to establish the two kinds of reading (paranoid/critical and reparative/affirmative) not as mutually exclusive, but as oscillating from one to the other. However, because paranoid readings are established as a kind of straw man to be critically attacked in 
Sedgwick's text, while the concept of reparative readings is more summarily described, the text becomes caught up in the logics of negative critique that it set out to overcome. Sedgwick's analysis falls into a paradox, making a paranoid critique of paranoid readings. In contrast, Muñoz provides a carefully theorized conceptualization of disidentificatory performance art. He presents it as a combination of critical hermeneutics from the perspective of disempowered minority subjects and aesthetic performative worlding practices, which creates new worlds and opens up spaces for the unfolding of queer of colour subjectivities (Muñoz 1999: 25). He thus demonstrates that such art simultaneously practises critical and affirmative worlding.

A common feature which characterizes political disidentification in the context of social movements, but which I think also spills over into theoretical disidentifications in academic feminisms, is intensely vibrating affectivities. Disidentification - both political and theoretical - is about passions and desires. Strong affects are at stake and translated into powerful feelings. For example, the rage and frustration that emerge when you, as an embodied and intersectionally situated subject, experience that you and/or the group with which you identify are denied a speaking position within the overarching movement or theoretical enterprise under whose banner you signed up in order to get your critique heard; or when theoretical frameworks do not capture the complex intersections that you experience as crucial. To be relegated to the position of a mute object because parts of your intersectionally situated identity are denied space to emerge, politically and/or theoretically, is painful, in the context of both political movements and academic feminist communities, and causes rage and frustration. But these feelings can also transform into catharsis and joy when they are translated into theoretical work, conceptualizing both the muting mechanisms and their transgression.

To speak politically and conduct research in the name of disidentification is to carve out positions of enunciation, where foreclosed and/or denied aspects of your situated and embodied identity and the identity of the group with which you identify can unfold politically and be worked through theoretically. Let me use Kimberlé Crenshaw's seminal text on intersectionality (1991) as illustration. Crenshaw frames the disidentificatory point of departure for speaking about violence against women of colour as an urge to theorize positions that 'resist telling' (Crenshaw 1991: 1242), on the one hand, due to white middle-class feminists' way of ignoring black feminist perspectives, and, on the other hand, to black anti-racist movements' silencing of the particular issue of violence against women. Crenshaw's invention and theorizing of intersectionality is to be understood as her conceptual answer to the political problem represented by these stories that resist telling. In this sense, her position of enunciation is critically disidentificatory as well as affirmatively oriented towards creating foundations for other and better worlding practices, which take into account the previously silenced perspectives of women of colour.

It is also important to note that the critical political and theoretical disidentificatory practices that I discuss, should not be collapsed into general notions of critique. Since Kant, critique has, in various ways, been presented as the epitome of rational Enlightenment thought and its celebration of the free individual's rebellion against authoritarian modes of thinking in terms of, for example, state rules or religion. From the Frankfurt School to Foucault (1997) and Butler (2003), critique has also taken on a special meaning, relating to the figure of the critical leftist intellectual. When I transpose disidentification from activism to academia, suggesting it as a key habit of academic feminisms, it could easily be collapsed into critique in the more general sense of core academic value. Or it could be misunderstood as just another version of 'critique' in the above mentioned traditions, especially, as Danish philosopher Sverre Raffnsøe (2017) suggests, it seems possible to read a dimension of affirmation into notions of critique, as theorized from Kant to Foucault and Butler.

To avoid such misunderstandings, I shall end this section of the article, summarizing the ways in which the notion of disidentification, discussed here, brings issues to the fore, which, on the one hand, are not reflected in the philosophical debates on critique discussed above, but, which, on the other hand, holds a potential to enrich them. I shall suggest that the notion of disidentification, as theorized by Butler (1993) and Muñoz (1999), can productively address the question which bothered Foucault (1997) as well as Butler (2003) in their reflections on the notion of critique, namely: how to keep up a positive concept of critique without recurring to Kantian free will? What I suggest here is that thinking about the notion of critique along the lines of disidentification, makes it possible to understand what prompts the kind of theoretical and political, social movement-related critique, that I have discussed with academic feminisms as a case in point, from a postconstructionist ${ }^{3}$, and non-voluntaristic feminist perspective. The notion of disidentification thus opens towards an understanding of the ways in which this kind of critique can emerge from an embodied politics of location, affectively grounded in a collective resistance against intersecting power differentials, as well as from the ways in which the collective resistance always already fails to take into account all dimensions of the intersectionally embodied locations of its different members.

\footnotetext{
${ }^{3}$ As I have discussed it more elaborately elsewhere (Lykke 2010), I define postconstructionism as a theoretical stance which takes into account the ways in which constructionism considers subjects to be produced in discourse, while also, from a new materialist perspective, reflecting on the agencies of bodies and other materialities. Or as Karen Barad (2007) articulates this under the banner of agential realism, a stance which both reflects 'how discourse comes to matter' and 'how matter comes to matter'.
} 


\section{OPEN-ENDED EVERYDAY UTOPIANISM}

Epistemologies of hope and utopian thought in academic feminisms make up the next focus of my cartography. In different ways, the proximity to political movements and activism has, I suggest, also led much academic feminism to tap into utopianism. This is a utopianism that is defined open-endedly in the sense of the desire for a better world, but without fixed blueprints (Levitas 1990: 9). Feminist and other, related social movements gather in one way or another to make a change for the 'better' in society. They emerge out of the desire for a way of being that is different and 'better', broadly understood as less discriminatory, more socially and environmentally just than current ones. Utopian thought has been criticized for its modern focus on linear time, and for universalizing hegemonic, homogenizing and, thus, exclusionary blueprints for the 'good' life and society. However, other strands of utopian thought have distanced themselves from such frameworks, and instead focused on utopianism as a multiple and open anticipation of alternative futurities, which materialize momentarily as part of a messy 'here and now'. It is this latter form of utopian thought which I see as resonating, in particular, with broad strands of feminism, including much academic feminism, and which in this sense can be understood as belonging to the epistemic habits nurtured in academic feminist communities.

To elaborate on this claim, I shall draw on newer utopia studies, focusing on 'everyday utopias' (Cooper 2014). In common with the strands in utopia studies oriented towards open-ended and multiple futurities, feminist utopia studies scholar Davina Cooper defines 'everyday utopias' as utopian processes and moments which are always already mixed up with the societal mechanisms and forces of the here and now, for example, neoliberalism, which push or pull in different directions than utopian ones in the above-mentioned sense.

In order to distinguish utopian moments and processes in the midst of the chaotic messiness of everyday events, Cooper (2014) suggests that we look at the interplay between concepts, imaginations and actualizations. In her analysis of everyday utopias, she is particularly interested in tracing discrepancies and instances where the three are not aligned - in other words, where there are cracks and gaps between them. In the moments of smooth and seamless alignment, the dimensions of utopian endeavours and societal mechanisms pulling and pushing in different directions may not be easily distinguished. However, reflections on moments of discrepancies between concepts and imaginings, on the one hand, and actualizations on the other, may, according to Cooper, create more insight, and also be useful for an understanding of the cases where moments of smooth alignment may create blind spots.

Reviewing the epistemic habits of academic feminisms with Cooper's reflections on everyday utopianism in mind, the first thing that appears to me is the conceptual and imaginative levels that often distinguish themselves through their hope and belief in the possibility of change for the better, in terms of less discriminatory, more socially and environmentally just worlding practices. I argue that such an open and multiple conceptual and imaginative utopianism cuts across not only political feminisms, but also much feminist scholarship. Let me give some examples.

When Butler argues for 'the possibilities of politicizing disidentification' (Butler 1993: 219), and suggests that 'the failure of identification' may become 'the point of departure for a more democratizing affirmation of internal difference' (Butler 1993: 219), she is expressing a hope and the belief in a change for something 'better'. Indeed, in Eve Kosofsky Sedgwick's above-mentioned reflections on paranoid and reparative readings (2003), she uses Butler (1990) as an example of the paranoid ones. Butler can be read from other angles, though. It is noteworthy that Sedgwick criticizes Butler for an overly strong and even naive reliance on the transformative effects of exposing oppression. But this kind of exposure which Sedgwick immediately dismisses as unproductive paranoia, a simple revealing of what is already known, can instead be understood as a strong affirmative belief in, and hope and desire for, radically changed worlding practices.

To line up a few more examples, let me once more refer to Crenshaw, who taps into hope for a transformation for the better when she suggests intersectionality as a tool to tell the story of violence against women of colour which 'resists telling' (Crenshaw 1991: 1242). Along similar lines, Sandoval's (2000) notion of 'differential consciousness' and Alarcón's 'identities-in-difference' (1991) are also important and hopeful tools. When Braidotti argues for feminist figurations, as 'politically informed account $[\mathrm{s}]$ of (...) alternative subjectivity' (Braidotti 1994: 1) that include a vision towards which the subject is moving in an intellectual, emotional and bodily sense, she, too, is articulating a tool for open and multiple utopian thinking in feminism. Or we can draw upon Haraway's framing of the notion of 'worlding' as 'a permanent refusal of innocence and self-satisfaction with one's reasons and the invitation to speculate, imagine, feel, build something better' (Haraway 2008: 92). Worlding is here framed as yet another tool for open-ended utopian thought.

In these feminist texts, disidentifications, intersectional storytelling, differential consciousness, identities-indifference, figurations and worlding practices are all suggested as tools that can anticipate and facilitate work towards futurities which in a multiple and open-ended feminist sense are 'better' than the here and now. This list 
of examples is just a few among many, presented here to support my point about the significant open-ended utopian desire for change embedded in different strands of feminist thought and imagination.

The question about actualization in institutional practices is a different one. While conceptualizations and imaginations are embedded in hope for a better world, actualizations are taking place within arenas where tensions, messiness and contradictions emerge. I shall discuss these in the next section under the heading 'cruel optimism' (Berlant 2011).

\section{CRUEL OPTIMISM}

The epistemic habit of cruel optimism is also in its own way oriented towards happy futures, but in terms of individualist neoliberal ideologies. I think it would be naive to believe that it is possible to build feminist institutions within the neoliberal academy without being influenced by the context within which we are working. Or, in other words, I do not consider it possible to individually 'opt out' of the structural conditions and mechanisms of governmentality imposed by neoliberal, capitalist society. Therefore, I do not believe that any university-employed critical intellectual subject, academic feminists included, can avoid being shaped by current neoliberal discourses, modes of embodiment and transcorporeal organization. However, I do claim that the utopianism of academic feminisms (or other critical studies) cannot be totally reduced to cruel neoliberal optimism. I do not think that neoliberal governmentality works on subjectivities in a smooth, uncontradictory and unidirectional fashion; there are residues, excesses, cracks and loopholes, and productive powerplays in a Foucauldian sense may be initiated in these messy spaces.

While I consider that my epistemic habit of disidentification and my orientation towards an open-ended utopianism have emerged out of the relationship between academic feminisms and feminist movements, the last item in my cartography, cruel optimism, has a different genealogy. It is an epistemic habit which I see as embedded in the relationship between feminist academics, the institutionalization of academic feminisms in neoliberalized universities, and the ensuing process of becoming disciplined to comply with academic regimes of neoliberal governmentality. To help me sort out this epistemic habit, I draw upon the work of Lauren Berlant (2011), who defines 'cruel optimism' as an attachment of the neoliberal subject to a desired object which, in the end, will give the subject a very hard time, or it might even destroy the subject. But, formed within neoliberal governmentality, the subject can nevertheless not stop desiring and pursuing the desired object.

Berlant defines 'cruel optimism' as a relation that exists 'when something you desire is actually an obstacle to your flourishing' (Berlant 2011: 1). Furthermore, she emphasizes that 'these kinds of optimistic relation are not inherently cruel. They become cruel only when the object that draws your attachment actively impedes the aim that brought you to it initially' (Berlant 2011: 1). In line with this definition, I suggest that 'cruel optimism' can be considered an epistemic habit of academic feminisms. This provocatively raises the question of whether the project of institutionalizing academic feminisms in the neoliberal university is so much of a contradiction in terms that those engaging in it might be said to be pursuing an impossible goal - the pursuit of which prevents its own flourishing.

This question is not new. Throughout the history of the institutionalization of academic feminisms, we who promoted this have often been confronted with the question. Worriedly, we have asked ourselves and been challenged by critiques as to whether or not institutionalization would compromise our feminist goals so much that they would be destroyed by the process. Let me quote as an example a new self-reflexive and critical investigation of the geopolitical grammar of Nordic gender research 1975-2005 and its problematic use of the concept of the 'Nordic':

On an overarching level, we could argue that a central dilemma for women's and gender studies is one that concerns whether institutionalisation itself is a good idea for a field that was founded on the very critique of academic institutions. (Dahl et al. 2016: 71)

Looking into the rhetoric of institutionalization discourses as they have unfolded over several decades, we can see that they are, in many ways, immersed in a happy optimism, as thoroughly demonstrated by this investigation of academic feminist constructions of 'the Nordic'. I suggest, in Berlant's sense and with genealogical hindsight, that the particular kind of optimistic rhetoric which over the years has been mobilized to celebrate the process of institutionalization of academic feminism in the Nordic countries, can be considered cruel. On the one hand, it is a rhetoric that is strongly attached to the process of institutionalizing as a way to obtain an economically and institutionally sustainable platform for developing new feminist onto-epistemologies and new ethico-political forms of academic bonding, both crucial for feminist research. But, on the other hand, this rhetoric glosses over the destructive work of the neoliberal university. This runs from the ways in which the economic necessity to constantly submit funding applications radically mould not only the rhetoric of academic feminisms, but also the 
very goals we set up for our research, to the ways in which fierce competition for scarce jobs and resources is the everyday situation, from which no one in academia is exempt, feminists and non-feminists alike. The main line of argument of Dahl, Liljeström and Manns' book (2016) makes this very clear, taking institutionalization in the northern regions of Europe as its case study. The authors argue forcefully that constructions of an unproblematized - hegemonic, homogenizing, exclusionary and implicitly white - Nordicness is important to note and criticize as a blind spot of mainstream feminist research in the region during the period in question, when women's/gender/feminist studies units mushroomed at universities all over the region.

The chapter covering the first part of the period of institutionalization during the 1970s and ' 80 s, for example, uses an analysis of the optimistic construction of self-satisfied Nordic difference to note how it created a hegemonic homogeneity, glossing over many dissenting views:

A general perception at the time seems to have been that dissentions concerning theoretical and political issues were likely to threaten a fragile unity that was needed in order to get a foothold in academia. Therefore, disagreement was put aside easily, even though there were large differences between standpoints on aims, objects, theories, and methods. (Dahl et al. 2016: 46)

Against the background of memory work on the same period, throughout which I was active as an academic feminist, I would like to add here that not only were theoretical and political discrepancies glossed over, but the spaces were definitely not as purely welcoming and different from the rest of academia as they are claimed to be in cruelly optimistic texts on institutionalization written back then (Dahl et al. 2016). They were instead permeated by personal fights over scarce resources and hard competition for far too few relevant jobs for feminist academics, especially those wanting to work with feminist theory and analysis. In this sense, these feminist spaces resembled the rest of academia, and were perhaps even more competitive, because jobs were fewer in academic feminism than in traditional disciplines. Moreover, the precarious situation of those fighting for the jobs was often proportionately greater due to the general mechanisms of discrimination against women, who made up the majority of participants flocking in and around academic feminist institutions. I know of feminist professors, well-known today, who back then were part-time teaching assistants in precarious situations and who were escaping to the toilets to hide their tears of rage and frustration about the 'welcoming space' (Dahl et al. 2016). I have also, in the midst of this 'welcoming space' heard different kinds of homophobic hate-speech such as claims about 'lesbian conspiracies' to help lesbian feminists into jobs while leaving heterosexual feminists in limbo. Thus, not only were theoretical discrepancies sometimes, albeit not always, kept behind the scenes, when the rhetorics of feminist unity, hope, optimism and sisterhood were constructed, so were the ways in which neoliberal working conditions took a heavy toll on feminist ethics of solidarity and collectivity.

Following Berlant, I interpret this situation through the lens of a cruelly optimistic attachment to an impossible goal. On the one hand, there was a passionate rhetoric of alternative feminist warmth and gestures towards happy research and teaching collectives and harmonious feminist institutions. On the other hand, it is clear that even these kinds of institutions must be understood as always already permeated by structurally imposed, neoliberal conditions that promoted individualism and strongly competitive conflict. However, in line with my cartography as a whole, I also claim that these academic feminist institutions gave rise not only to the unfolding of hegemonic and cruel optimisms, but also to critically disidentificatory conceptualizations, imaginations, worlding practices and open-ended everyday utopianisms, including ethics of caring and collectivity. I, thus, consider these institutions as best understood as unruly spaces where neoliberal cruel optimisms, critical disidentifications and feminist utopian worlding practices are messily performed as entangled in each other.

\section{CAN EPISTEMIC HABITS BE CHANGED?}

I am hopeful enough to believe that epistemic habits can be changed for the better, and I think that the collective disidentificatory practices and everyday utopian orientations which have contributed to the shaping of feminist politics and theorizings testify to this. However, it is hard work, and the result is definitely not pre-given. The ways in which disidentifications and everyday utopianism can become interwoven with cruel, neoliberally framed optimism demonstrate that failure is as likely an outcome as success when it comes to changing such habits for the better in an open-ended feminist utopian sense.

In the final section of this article, I shall discuss what I see as a couple of important prerequisites for catalyzing change in the current situation: attentiveness to the effects of changing conditions of academic knowledge production, and indepth reflections on its geopolitical grammars. The impact of both these dimensions on academic feminisms and epistemic habits have been undertheorized. Even though situated knowledges and the politics of location are often cited as key to feminist theorizing, these particular aspects of situatedness are often taken for granted, and have come to figure as blind spots. 
Even though I emphasize cruel optimism as part of my cartography of epistemic habits, I do not, as mentioned, wish to merely dismiss academic feminisms as purely embedded in neoliberal modes of thinking and acting. Instead, I am arguing for the importance of admitting to cruel optimism when trying to understand the epistemic habits of an academic feminism which, on the other hand, cannot be restlessly reduced to this kind of neoliberally induced epistemic habit. Therefore, studies are much needed that critically sort out those dimensions of epistemic habits which are effects of neoliberal working conditions. I have tried to develop my cartography along such lines. But to change epistemic habits in this regard will also include fully exploring the paradoxical intra-actions of feminist activism and neoliberalized university.

It is part of current neoliberal conditions that the grounds on which feminist academic institutions such as Centres and other units for Women's, Gender or Feminist Studies stand are paradoxical and pervaded by contradictions. To briefly elaborate upon these contradictions and tensions, which I suggest that academic feminists should take more thoroughly into account when critically scrutinizing epistemic habits, I shall refer to the discussion about the transformation from so-called mode 1 academic knowledge production to mode 2 (Gibbons et al. 1994; Nowotny et al. 2001). In creating a better understanding of the conditions for the epistemic habits of academic feminisms, I think it is illuminating to consider mode 2 knowledge production as fitting the bill of neoliberalism, while, in paradoxical ways, also sometimes generating platforms for transgressive disidentificatory criticalities and utopian worlding practices.

According to Gibbons et al. (1994) and Nowotny et al. (2001), mode 1 knowledge production is disciplinary and characterized by homogeneity and stable academic hierarchies, based on gender/sex, race, ethnicity and class. By contrast, mode 2 is transdisciplinary and characterized by heterogeneity, commercialization, dependence on external funding, more ad hoc structures and 'massification' (mass admission of students). While mode 1 universities, in their classic form, were elitist and exclusive, admitting primarily young white men from the upper and middle classes, transformations into mode 2 implies a massification of student populations. Even though these new student populations in particular have a background in the quickly growing middle classes, and social inequalities in terms of class and racialization are clearly profiled (Brade 2017), the massified student populations, nevertheless, changes the foundations of universities radically, posing new questions and making new demands.

When I discuss mode 1 and mode 2 in this way, a certain historicity is at stake, in the sense that mode 2 knowledge production is claimed currently to become more widespread in tandem with neoliberalism, and globalized and commercialized knowledge production. But, according to Gibbons et al. (1994), and Nowotny et al. (2001), the two modes should be understood as neither mutually exclusive nor as two separate points on a linear historical timeline. As mentioned in the introduction, while neoliberalization is taking place on a global scale, different national university politics as well as unequal global relations make materializations happen very unevenly.

In its classic form, the mode 1 university was an institution, governed by white, well-off men from the bourgeois classes, deeply convinced about their right to supremacy over their gendered, classed, racialized, colonialized, animalized, sexualized, disabled etc. others. There was not much doubt among the representatives of that university that white men (i.e. the version of the human who perfectly mirrored themselves) were exceptional, and had a right, given directly by the Christian God (no other gods counted), to rule, control, objectify and classify all human and non-human others. Confirming this exceptionalism, and narcissistically enjoying the convenient powers it gave to those in charge of the classic mode 1 university, was basically what many of its scientific endeavours were designed to do.

The foundations (albeit not its institutional echoes in the shape of disciplines, ontologies and epistemologies) of the classic mode 1 university are today becoming more and more eroded by transnational neoliberal capitalism sweeping across the world, transforming knowledge production into a commercialized business, producing consumer goods. Even critical knowledge is nowadays generated in the shape of consumer goods, when transformed into publications by commercial publishers or university courses to be sold on the market.

However, it is also worthwhile noticing that, according to Gibbons et al. (1994), and Nowotny et al. (2001), the foundations of the mode 1 university are being undermined not only by transnational neoliberal capitalism, but also by massification of student populations - i.e. by the opening up of universities worldwide to massive numbers of new students' groups with intersectionally different backgrounds, differing from the white male European and US upperclass elites which exclusively populated classic mode 1 universities. Even though these kinds of academic elites (like other powerful throwbacks to mode 1) still hold much positional power, their power is not as unchallenged as it used to be.

When considering the history of the students' movement in the aftermath of the 1968 revolt, its alliances with workers' and anti-imperialist movements, protesting the Vietnam war, the Israeli occupation of Palestine and apartheid in South Africa, and its attempts to theorize these fights under the banner of Marxism in universities, it seems pertinent to acknowledge that the challenges coming from massification actually helped to undermine the mode 1 university, epistemologically, politically and organisationally. Moreover, it is important to acknowledge that the massification of student populations since then have given rise to ever-renewed revolts which have happened 
and continue to happen in many places all over the world (for example Tiananmen Square 1989 in China, and present-day South Africa, \#FeesMustFall), and that a political effect of this worldwide massification has been and is a proliferation of critical studies of all kinds - decolonial, anti-racist, feminist, queer, transgender studies. Massification has happened in tandem with students' movements, which have prompted many kinds of radical criticality that in varying degrees and unevenly geographically distributed have succeeded in gaining space and making an impact on academia worldwide, creating spaces for everyday utopianism.

The neoliberalizisation of universities is, thus, fraught with tensions and productive contradictions which need to be strategically taken into account. But to do so demands new epistemic habits and self-reflexivity on new levels. I suggest that it requires the collective development and nurturing of epistemic cultures in which the thinking through of the societal and material context of one's knowledge production figures as one of the important criteria for good research.

I shall also suggest that these much-needed new reflections on context and conditions for one's knowledge production should include a taking into account of the geopolitical grammars in which one's research is embedded. When framing this requirement with reference to the concept of geopolitical grammars, I am indebted to the aforementioned volume by Dahl, Liljeström and Manns (2016), which develops this concept as a critique of the ways in which constructions of the 'Nordic' in academic feminisms in the northern regions of Europe has been represented as a taken-for-granted and unscrutinized blind spot.

It goes without saying that the onto-epistemological and methodological move suggested here by Dahl et al. (2016) has importance beyond the northern regions of Europe. But again, it is also important to notice that such a move is more easily discussed than performed. Many disciplines, sub-disciplines and interdisciplines are pervaded by epistemic habits of methodological nationalism/regionalism, universalization and the use of geopolitical distinctions that are too crude and homogenizing, and many academic research traditions have established these approaches as their horizon. Academic feminisms are part of this landscape, and are also, in many ways, affected by this predicament and the lack of tools to go beyond this state of affairs. To transgress the logics of problematic geopolitical grammars, therefore, requires a deepened critique of the disciplines, sub-disciplines and interdisciplines.

Here, too, I think it is urgent to nurture and encourage a rethinking of epistemic habits. But it is also important to recognize that transgressions of these limited and problematic outlooks are already on the agenda of some current strands of theorizing and analysing, including both converging and differing feminist ones, such as decolonial feminisms (Tlostanova and Mignolo 2012), postcolonial feminisms (Mohanty 1988) transnational feminisms (Kaplan, Alarcón, and Moallem 1999), postsocialist feminisms (Atanasoski and Vora 2017), and subaltern theories (Spivak 1988).

\section{CONCLUSION}

I have critically reviewed three epistemic habits: disidentifications, everyday utopianism and cruel optimism and drawn a personalized cartography of epistemic habits in current academic feminisms. I consider these habits to be interwoven, so even though the first two are, in my view, to be valued positively and need to be further elaborated, the interweaving with the problematic third one, cruel optimism, needs also to be thoroughly considered. Moreover, I have suggested expanding our epistemic habits to include critical scrutiny of the impact of neoliberal working conditions on academic feminist knowledge production and more in-depth reflections on geopolitical grammars. Both epistemic moves should be integrated more fully into the approaches of academic feminisms.

As I have emphasized throughout, my focus is on a cartography of epistemic habits that have meant a lot to me in my personal enactment of academic feminisms, located in the northern region of Europe. In saying this, I do not mean to suggest that I could have articulated them in this way at the time. But, in genealogical hindsight, reviewing my 45-year-long engagement with feminist activism, theorizing and the professionalization of academic feminisms in the shape of institution building, I see them as important to my approaches.

I have also expressed the hope that epistemic habits can be changed, and I have advocated changes that I believe to be important in the current global situation. I see reflections such as those that the editors of this special issue have encouraged the contributors to perform in terms of reviewing epistemic habits to be a productive step towards fostering such changes when it comes to overcoming habits built on epistemologies of ignorance and to the fostering of new and better habits. However, I do also think that it is important to be modestly aware that a situation of total transparency and complete transcendence of such epistemologies can never be achieved. This would require a god-trick which, with Haraway (1991), I reject as a positivist illusion. But I do believe that listening to the challenges brought by ever-new critically worlding and feminist disidentifying voices is of utmost importance. I would also argue that academic feminist institutions should act as gate-openers rather than gatekeepers, welcoming such disidentifications and establishing transversal dialogues (Yuval-Davis 1997) to work collaboratively with them. In this way, these institutions should try to create new synergies and alliances, and new 
open-ended everyday utopian worlding practices, still taking into account the messiness that often enters into the picture when moving from conceptualizations and imaginations to actualizations. As Cooper (2014) reminds us, everyday utopias are neither purely utopian, nor purely caught up in destructive logics of the here and now. They are messy, but in a hopeful way.

\section{REFERENCES}

Alarcón, N. (1991). The Theoretical Subject(s) of 'This Bridge Called My Back' and Anglo-American Feminism. In: H. Calderon and J.D. Saldivar, eds., Criticism in the Borderlands: Studies in Chicana Literature, Culture and Ideology (pp. 28-43). Durham and London: Duke University Press.

Atanasoski, N. and Vora, K. (2017). Postsocialist Politics and the End of Revolution. Social Identities, 23(4), pp. 116. https://doi.org/10.1080/13504630.2017.13211712

Barad, K. (2007). Meeting the Universe Halfway: Quantum Physics and the Entanglement of Matter and Meaning. Durham and London: Duke University Press.

Berlant, L. (2011). Cruel Optimism. Durham and London: Duke University Press.

Brade, L.H. (2017). Vi, de neutrale. Skitser til udfordring af akademisk forstehed. Lund: Lunds universitet, Samhällsvetenskapliga fakulteten. Genusvetenskapliga institutionen.

Braidotti, R. (1994). Nomadic Subjects: Embodiment and Sexual Difference in Contemporary Feminist Theory. New York: Columbia University Press.

Bryld, M. and Lykke, N. (2000). Cosmodolphins: Feminist Cultural Studies of Technology, Animals and the Sacred. London: Zed.

Butler, J. (1990). Gender Trouble: Feminism and the Subversion of Identity. London and New York: Routledge.

Butler, J. (1993). Bodies that Matter: On the Discursive Limits of "Sex". London and New York: Routledge.

Butler, J. (2003). What is Critique? An Essay on Foucault's Virtue (2000). In: S. Salih with J. Butler, eds., The Judith Butler Reader (pp. 302-322). Malden, MA: Blackwell.

Chow, R. (2006). The Age of the World as Target. Self-Referentiality in War, Theory, and Comparative Work. Durham and London: Duke University Press.

Cooper, D. (2014). Everyday Utopias. The Conceptual Life of Promising Spaces. Durham and London: Duke University Press.

Crenshaw, K. (1991). Mapping the Margins: Intersectionality, Identity Politics, and Violence against Women of Color. Stanford Law Review, 43(6), pp. 1241-1299.

Dahl, U., Liljeström, M. and Manns, U. (2016). The Geopolitics of Nordic and Russian Gender Research, 1975-2005. Stochkholm: Södertörn Academic Studies.

Dutschke, R. (1980). Mein langer Marsch: Reden, Schriften und Tagebücher aus zwanæig Jabren. Hamburg, DE: Rowohlt.

Forstorp, P. and Mellström, U. (2013). Eduscapes: Interpreting Transnational Flows of Higher Education. Globalisation, Societies and Education, 11(3), pp. 335-358.

Foucault, M. (1997). What is Critique?. In: S. Lotringer, ed., The Politics of Truth (pp. 41-83). Transl. L. Hochroth and C. Porter. New York: Semiotext(e).

Gibbons, M., Limoges, C., Nowotny, H., Schwartzman, S., Scott, P. and Trow, M. (1994). The New Production of Knowledge: The Dynamics of Science and Research in Contemporary Societies. London: Sage.

Haraway, D. (1991). Situated Knowledges: The Science Question in Feminism and the Privilege of Partial Perspective. In: Simians, Cyborgs and Women: The Reinvention of Nature (pp. 183-201). London: Free Association Books.

Haraway, D. (2008). When Species Meet. Minneapolis: University of Minnesota Press.

Haraway, D. (2016). Staying with the Trouble: Making Kin in the Chthulucene (Experimental Futures). Durham and London: Duke University Press.

Kaplan, C., Alarcón, N. and Moallem, M. (eds). (1999). Between Woman and Nation. Durham and London: Duke University Press.

Klein, M. (1988). Envy and Gratitude. London: Virago.

Latour, B. (2004). Why Has Critique Run Out of Steam? From Matters of Fact to Matters of Concern. Critical Inquiry, 30, pp. 225-248. The University of Chicago. https://doi.org/10.1086/421123

Levitas, R. (1990). The Concept of Utopia. Oxford: Peter Lang.

Lionnet, F. and Shih, S. (eds). (2011). The Creolization of Theory. Durham, London: Duke University Press.

Lykke, N. (1993). Rotkäppchen und Oedipus. Zu einer feministischen Psychoanalyse. Wien: Passagen Verlag.

Lykke, N. (2010). Feminist Studies: A Guide to Intersectional Theory, Methodology and Writing. New York: Routledge.

Lykke, N. (2014). Passionate Disidentifications as an Intersectional Writing Strategy. In: N. Lykke, ed., Writing Academic Texts Differently: Intersectional Feminist Methodologies and the Playful Art of Writing (pp. 30-47). New York: Routledge. 
Martinsson, L., Griffin, G. and Giritly Nygren, K. (eds). (2016). Challenging the Myth of Gender Equality in Sweden. Bristol: Policy Press.

Mohanty, C.T. (1988). Under Western Eyes: Feminist Scholarship and Colonial Discourses. Feminist Review, 30, pp. 49-74.

Muñoz, J. E. (1999). Disidentifications: Queers of Color and the Performance of Politics. Minneapolis and London: University of Minnesota Press.

Nowotny, H., Scott, P. and Gibbons, M. (2001). Re-Thinking Science: Knowledge and the Public in an Age of Uncertainty. Cambridge: Polity.

Plumwood, V. (1993). Feminism and the Mastery of Nature. London and New York: Routledge.

Puar, J. (2007). Terrorist Assemblages. Homonationalism in Queer Times. Durham and London: Duke University Press.

Raffnsøe, S. (2017). What is Critique? Critical Turns in the Age of Criticism. Outlines - Critical Practice Studies, 18(1), pp. 28-60. Available at: https://tidsskrift.dk/outlines/article/view/26261

Sandoval, C. (2000). The Methodology of the Oppressed. Minneapolis and London: University of Minnesota Press.

Sedgwick, E.K. (2003). Touching Feeling: Affect, Pedagogy, Performativity. Durham and London: Duke University Press.

Spivak, G.C. (1988). Can the Subaltern Speak?. In: C. Nelson and L. Grossberg, eds., Marxism and the Interpretation of Culture (pp. 271-313). Basingstoke: Macmillan Education.

Spivak, G.C. (2003). Death of a Discipline. New York: Columbia University Press.

Sullivan, S. and Tuana, N. (eds). (2007). Race and Epistemologies of Ignorance. Albany: State University of New York Press.

Tlostanova, M. and Mignolo, W. (2012). Learning to Unlearn. Decolonial Reflections from Eurasia and the Americas. Columbus, Ohio: Ohio State University Press.

Wiegman, R. (2012). Object Lessons. Durham and London: Duke University Press.

Yuval-Davis, N. (1997). Gender \& Nation. London: Sage.

Citation: Lykke, N. (2017). Academic Feminisms: Between Disidentification, Messy Everyday Utopianism, and Cruel Optimism. Feminist Encounters: A Journal of Critical Studies in Culture and Politics, 1(1), 03. https://doi.org/10.20897/femenc.201703

Copyright (C) 2017 by Author/s and Licensed by Lectito BV, Netherlands. This is an open access article distributed under the Creative Commons Attribution License which permits unrestricted use, distribution, and reproduction in any medium, provided the original work is properly cited. 


\title{
Religion, Intersectionality, and Epistemic Habits of Academic Feminism. Perspectives from Global Feminist Theology
}

\author{
Elina Vuola 1*
}

Published: October 30, 2017

\begin{abstract}
This article pays critical attention to the ways in which academic feminism has regarded religion. Issues related to religion and gender have by and large either been ignored or treated quite stereotypically. I have called this phenomenon a simultaneous under- and overestimation of religion. The phenomenon is not global. Feminists of the global south tend to pay much more and more multi-faceted attention to religion than scholars from the global north. I will illustrate this problem through a close reading of intersectionality in feminist research in religion, especially feminist theology. My argument - which can be supported by evidence from historical records - is that what has been called intersectionality since Kimberlé Crenshaw, has in fact been explicitly present in early feminist theology (1970s-). The reason why feminist liberation theologians stressed the interstructuring of gender, class, and race/ethnicity lies in their practical and theoretical cooperation with liberation and feminist theologians from the global south, for example through the Ecumenical Association of Third World Theologians (EATWOT). My article is a critical re-reading of the history of feminist theorizing from the perspective of religious feminists, academic feminist theologians and liberation theologians from both the global north and south (including black and womanist theologians from the USA, Latin America and Africa). My aim is to correct a long-held understanding of the history of feminist theorizing as purely "secular".
\end{abstract}

Keywords: feminist theology, liberation theology, feminist theory, religion, intersectionality

\section{INTRODUCTION}

In my article 1 I pay critical attention to the ways in which academic feminism has regarded religion. I argue that interdisciplinarity in feminist studies is not always practised or is practised selectively. I suggest that research on the study of religion is seldom substantially engaged with in the field of feminist studies or considered as part of feminist theory proper. Therefore, I am articulating an epistemic habit of exclusion as well as calling for greater and deeper interdisciplinarity in feminist studies.

My intention is to engage in a critical re-reading of the history of feminist theory from the perspective of religious feminism. This includes academic feminist theology, and liberation theology from both the global north and south, including black and womanist theologies from the United States, Latin America, and Africa. I wish to shed light on aspects of feminist thinking that have remained in the shadows, because of a persistent misrepresentation of the history of the feminist movement and of a representation of feminist theorising as purely secular. In this, I join feminist historians, who have stressed and documented the importance of religion for $19^{\text {th }}$ and early $20^{\text {th }}$ century feminists as well as for more contemporary feminists (e.g. Braude 2001; contributors to Braude, ed. 2004; Hammar 2010; Kinnunen 2014).

In order to make my argument about the exclusion of religion more concrete, I will analyse how the idea of intersectionality has been employed in feminist theology much earlier than in other fields of feminist studies. ${ }^{2}$

\footnotetext{
${ }^{1}$ This article has been written within the research project Embodied Religion. Changing Meanings of Body and Gender in Contemporary Forms of Religious Identity in Finland, directed by myself and funded by the Academy of Finland (2013-17).

${ }^{2}$ The only other field with such an early direct relationship with feminist organising and theorising in the south is probably feminist development studies (Vuola 2016: 317).
} 
Obviously, black feminism in the United States is the most important historical background for the development of such an intersectional feminism which looks at gender in relation to race and class. However, my argument, which can be sustained through historical records, is that what is called intersectionality since Kimberle Crenshaw coined the term in 1989, has been explicitly present in feminist theology since the early 1970s. This included black feminist theologians who started to call their work womanist theology, the term 'womanist' inspired by Alice Walker (1983). Even in the history of black feminism, the importance of religion and theology has, I argue, often been ignored.

Since the early 1970s, feminist theologians stressed the significance of the interstructuring of gender, class, colonialism, race, and ethnicity, to emphasise their practical and theoretical cooperation with liberation and feminist theologians from the global south. They did not use the term 'intersectionality', but they conceptually meant the same. I emphasise that what feminist theologians did was to theorise the experiences of multiple oppressions. They paid attention to the intersecting categories of gender, class and race and addressed colonialism, north-south relations and worked within a global perspective in their theorising and writing. This resulted in a body of work that has yet to be fully explored. Further, I argue that the work of feminist theologians should be considered as part of the intellectual history of academic feminism, as it forms a body of work that shows us the need to analyse power and oppression beyond the singularity of identity categories.

Finally, I present a short history of the global ecumenical and interfaith processes of dialogue between religious feminists and feminist theologians as one not widely considered locus of history of feminism, which also was of importance for the development of feminist theology. These connections between women from different parts of the world can be understood as a parallel development to their secular counterpart within the United Nations. The extent to which the two processes, the secular and the religious, overlapped and how, is an issue to be explored in future research. Churches and religious institutions form concrete transnational networks with both local and global constituencies and their own support and financing systems. Religious institutions and communities have access to all levels of society in all parts of the world. To overlook their importance in the development of women's transnational dialogue and support systems is to overlook an important and well-established part of global feminism.

Feminist theorists of the global south tend to pay much more attention to religion and in a more multi-faceted way than gender scholars from the global north (e.g., Narayan 2000). The interplay of colonialism, religion, and gender, both historically and currently, has made it necessary for feminists in colonialised regions to be more sensitive to religion. For example, they pay attention to the ways religion has historically played a role in portraying women in colonialised regions as subordinate and in need of Western civilising effects (e.g., Ahmed 1992). At the same time, their attention towards religion is not only critical or negative: different religious traditions hold also empowering aspects for women. ${ }^{3}$

I will demonstrate how feminists from different faith traditions used ecumenical and interfaith networks that had been well-established at least since the Second World War as a context for developing feminist theologies. These were created with the aim of forming a critique of religion that would be attentive not only to gender and women's position in different religious traditions, but also to colonialism, class, race, and ethnicity. ${ }^{4}$

My emphasis in this article is historical: through tracing the development of global feminist liberation theology, I bring religion to the centre of feminist historiography. Thus, my article is not only an example of a critical rereading of the history of feminist theorising, but also a critique of the epistemic habit of excluding feminist theology in academic feminism. Because of my emphasis on early feminist theology, it is beyond the scope of this article to analyse if and how the concept of intersectionality is included in contemporary feminist theology. ${ }^{5}$

Nuanced analyses of gender and religion derive from a variety of perspectives and cultural contexts in religious studies, anthropology, theology, and sociology of religion. As I argue throughout this article, a lack of substantial dialogue with those fields of study results in a somewhat outdated understanding of what is considered feminist studies proper. The result is both a too narrow presentation of feminist theory in general because of the exclusion of the study of religion, and a too-thin and even misconstrued understanding of the interplay between religion and gender.

\footnotetext{
${ }^{3}$ However, I have been critical of this oblivion of the more positive aspects of religion in the context of Latin America. The Catholic Church as a socially and culturally powerful institution is strongly criticised —and often rightly so-by feminist activists and scholars of the region, but often without an adequate understanding of the multiple meanings Catholicism holds for women (Vuola 2006: 142-148; Vuola 2009: 221-227; Vuola 2012b).

${ }^{4}$ I make this point in Vuola 2016, but develop it here further and in more detail.

${ }^{5}$ Analysing contemporary feminist theology and its development since the 1980 s could be the subject of another article. Here my point is explicitly historical in order to trace some of the more invisible sources of feminist thinking. In the feminist theology of the 1970s and 1980s, much like in other fields of research, the focus was on women. This has changed in more recent feminist theology, but since my focus is in the early phase, I am not discussing the problems which later feminist thinking has seen in the identification of 'gender' with 'women'.
} 
Following Clare Hemmings' (2011) insistence on paying attention to the stories that are told and mechanisms of exclusion in the historical record of academic feminism, I wish to highlight an excluded body of work: the meaning and importance of religion, and more specifically, of global feminist theology. I consider feminist theology to be early feminist theorising which is both intersectional and international in its approach and scope.

\section{RELIGION AND THE NARRATIVES OF ACADEMIC FEMINISM}

The phenomenon of the treatment of religion in feminist theory could be described as a simultaneous underand over-estimation of religion. In the former case, the under-estimation has also been called feminist blindness to the importance of religion (for women), especially in its positive aspects, whereas the latter case points to a religion-as-a-lens type of theorising, in which religion is seen as the main explanatory factor of women's lives in a given culture, mainly in negative terms: religion as the root of women's oppression (Vuola 2012a: 497; Vuola 2015a: 17). According to Ursula King:

At present there still obtains a harmful 'double blindness' in which most contemporary gender studies, whether in the humanities, social sciences, or natural sciences, remain extraordinarily 'religion blind', whereas far too many studies in religion are still quite 'gender blind'. (King 2005: 3297)

There are several reasons why such a simplistic view of religion is so prevalent in feminist studies. One of the reasons is the influence of the so-called secularisation thesis; although it is questioned today, it has influenced the social sciences, including much of feminist theorising. Secularisation was seen as a universal and inevitable development, even though case studies have proven the opposite (Casanova 1994). Only lately, with the resurgence of religion in Western societies, both as a renewed interest in spirituality and as a result of religion-based violence and terrorism, social scientists have acknowledged that the prediction was false or at least overestimated. The obvious and well-documented sexism of different religious traditions is another reason for a polarised view of religion in feminist studies. What both approaches lack is the acknowledgement of the long history of religious feminism and the related theoretical work, known as feminist theology particularly in the Anglo-American world. ${ }^{6}$ The contemporary post-secular approach in gender studies (e.g., Braidotti 2008) is an attempt to address this neglect of religion, but without an in-depth discussion and dialogue with the substantial and diverse body of work of feminist scholars of religion.

In the late 1990s, the Swedish historian Inger Hammar (1998) pointed out that feminist historians have too often been 'religion blind', not only in relation to women, but also particularly in the case of early feminists. She later wrote:

Since it has been long assumed that the emancipation of women and secularization went hand in hand, research into the history of Swedish women has spent little time in tracing the strongly Christian tone of the feminist movement. (...) In doing so, historians have overlooked the contradictions inherent in the fact that from the middle of the nineteenth century, the women who first initiated and then drove forward the emancipation debate were ideologically anchored in a context that has been labelled as hostile to emancipation. (Hammar 2010: 57-58)

Similarly, in the American context, Catherine Brekus writes: "At the same time as American religious historians have failed to write about women, many American women's historians have failed to consider religion" (Brekus 2007: 24 , emphasis in original). She claims that women's historians have been especially blind to the continuing power of religion in modern America, ' (...) as if women never went to churches, synagogues, or mosques. (...) When they [women's historians] have written about the feminist movement of the 1960s and 1970s, they have simply assumed that it was secular in nature' (Brekus 2007: 27). She goes on to suggest the effects on women's identities by saying:

Ironically, women's historians have prided themselves on recovering the stories of forgotten women, yet whether intentionally or not, they have engaged in their own kind of forgetting. Many have virtually erased women's religious identities (Brekus 2007: 26).

In 2002, historian Ann Braude convened a conference at the Harvard Divinity School in which I participated; it was a gathering of the first generation of feminist theologians and religious leaders from different faith traditions in the United States. In the introduction to the proceedings of the conference, Ann Braude wrote:

\footnotetext{
${ }^{6}$ The term feminist theology is problematic for many reasons beyond Christianity. It is either not used at all, or, as in the case of Islam, most feminist scholars are legal scholars or social scientists, not 'theologians' even when they write primarily on issues related to religion.
} 
As a group, religious feminists have worked over the last forty years to lift the religious women of the ages from obscurity, to acknowledge their roles in scripture, ministry, theology, worship, teaching, and devotion. Imagining and constructing non-sexist religious models for the women and men of the future, they have critiqued the conditions that fostered women's exclusion, so that those conditions can be changed. What a dreadful irony it would be, if their own history, the story of religion's interaction with feminism, fell out of the narrative, just at the moment when the history of the second wave is being written (...). (Braude 2004: 3)

Braude refers to the way in which the historiography of second wave feminism in the United States tends to leave out the voice, thoughts, and activities of religious feminists and academic feminist theologians. This epistemic gesture, for her, as a historian of religion, is 'inaccurate, a misreading of America's past' (Braude 2004: 2).

To tell the story of second-wave feminism and feminist theory in purely secular terms is problematic as it makes feminist scholarship on religion and religious feminism invisible. In another text, Braude (2001: xxii-xxiv) provides two broad arguments for why the inclusion of religion within the historical assessment of feminism as an ideology and as a political movement in both the $19^{\text {th }}$ and $20^{\text {th }}$ centuries is important. First, it can help dispel the idea that religion and feminism are opposing forces. This is an assumption shared by both conservative religious sectors and feminism, and based on misconceptions about the relationship between religion and feminism (ibid.: xxii). Second, including religion in analyses of the history of feminism is necessary to provide an accurate assessment of the movement's impact in a given society. Part of this impact happened in different religious traditions. Many religious feminists chose to maintain ties to their communities of faith while participating in the struggle for women's rights (including as founding members of the National Organization of Women in the United States). Besides their work in secular contexts, these feminists also held that religion was often an important aspect of their activity (ibid.: xxiii). I concur with Braude regarding her hope to "contribute to the continuing challenge of incorporating feminism into religious history and religion into the history of feminism' (ibid.: xxiv).

A recent example of the neglect of religion in feminist theory and historiography is particularly illuminative because of its explicit goal to critically re-read the history of feminist theory as an excluding endeavour. Clare Hemmings' critique of the dominant narratives of Anglo-American feminist theory as a narrative of progress (loss and return) and her insistence on alternative histories and narratives (Hemmings 2005 and 2011) is compelling. Hemmings (2005) identifies, describes, and analyses the dominant stories that academics tell about the development of Western, second-wave feminist theory. She suggests that despite a rhetorical insistence on multiple feminisms, Western feminist trajectories emerge as startlingly singular. In her later work (2011), she emphasises the need for alternative stories that 'highlight what has been left out and endeavour to reinsert those omissions into the historical record' (2011: 13).

Despite Hemmings' insistence on correcting the omissions, she does not address the vast amount of scholarship that carefully documents the (sometimes intimate) relationship between religion and feminism in different parts of the world. It is not only the representation of the development of feminist theorising in terms of waves (with their corresponding decades), which is problematic, as Hemmings points out. The problem is also the omission of vast waters that may have their own 'waves' of feminist theorising. It should be noted that Hemmings' work is based on an analysis of a certain body of work. Hemmings' sources are those that by and large render religion invisible. Thus, it is telling that religion is not part of this material: not paying attention to religion is indeed a habit of feminist scholarship, which Hemmings however reproduces in her own work.

Hemmings' critique of the dominant narratives and their corresponding shifts and waves according to decades as well as her notion that this tale is primarily Western and Anglo-American is, in my view, brilliant. However, her omission of religion and the global feminist study of religion is revealing of the narrowly secular and Western framework of what is conceived as feminist theory.

In order to bring the history of feminist theology at the heart of feminist theory and make my argument about the importance of inclusion of religion more concrete, I will next analyse how the idea of intersectionality has been employed in feminist theology earlier than the history of intersectionality acknowledges. I start with a more general discussion of intersectionality and the study of religion.

\section{INTERSECTIONALITY AND RELIGION}

Intersectionality is not a unified theory or approach. It is not a grand new theory, but rather one way of conceptualising a central theoretical development in recent feminist theory. There are different ways of understanding and using the concept of intersectionality in contemporary feminist theory. There are various ways of understanding and naming the object of intersectional analysis: it can be asymmetries of power structure, identity (formation), difference, and social division (Lykke 2003: 48 and 2005; Nash 2008; Yuval-Davis 2006). Sometimes these differences are related to disciplinary differences, such as philosophy and sociology, resulting in differences 
of focus. What all the approaches have in common is the analysis of mutually constructing systems of power through which differences such as ethnicity, race and gender are understood not only as forms of identity (positive and critical) but as categories penetrated by social, cultural and political power.

Even theories of intersectionality that explicitly pay (self-) critical attention to the blind spots of feminist theory and the myriad differences among women, have by and large not been able to see religion as an important factor in (marginalised) women's lives. In fact, most theorists of intersectionality do not even mention religion (besides Crenshaw, and other widely quoted scholars such as Davis 2008; Ludvig 2006; Lykke 2005; McCall 2005; Nash 2008). Those scholars who at least mention religion, even if on a rather general level, as a 'difference' or 'category' to be considered tend to be those who think within postcolonial feminism. For example, Avtar Brah and Ann Phoenix ask how do we challenge simplistic binaries which posit secularism and fundamentalism as mutually exclusive polar opposites?' (Brah et al. 2004: 83) and even take the title of their article 'Ain't I a Woman?' from Sojourner Truth, the black slave who in her 1851 speech challenged both sexism and racism on the basis of her God-given equality. Truth's speech is yet another example of the long history of interaction between religion and feminism. Also, Nira Yuval-Davis (2006: 205) mentions religion as one of the social divisions to be applied especially in international human rights discourses and practices.

Through intersectionality, a process of diversification of central concepts such as gender and women and the inclusion of differences between women has happened, largely through the inclusion of race, class, ethnicity, and sexual orientation into feminist theory. ${ }^{7}$ Intersectionality is a broad way of theorising gender in relation to these other differences and constructions of identity and selfhood, showing how a variety of oppressive structures such as sexism and racism - influences these. Religion has rarely been mentioned among these differences, and even less so as an empowering factor in spite of the insistence of religious feminists from different parts of the world.

Several feminist scholars of religion have pointed out this omission. For example, according to Elizabeth Castelli:

(. . .) if 'women' has long been recognized as too abstract a category to be useful for analysis, religion has rarely been included in the litany of qualifiers (race, class, culture, ethnicity/nationality, sexuality) by which 'women' becomes an evermore marked and differentiated category. Yet, feminist scholars who intervene in the academic study of religion have often drawn attention to the complicated role that religion has played in identity formations, social relations, and power structures. 'Religion' as a category often cuts across other categories by which identities are framed (gender, race, class, etc.), and it often complicates these other categories rather than simply reinscribing them. (2001: 4-5)

Anthropologist Saba Mahmood (2005), who has done fieldwork among conservative Muslim women in Egypt, expresses a similar view:

Over the last two decades, a key question has occupied many feminist theorists: how should issues of historical and cultural specificity inform both the analytics and the politics of any feminist project? While this question has led to serious attempts at integrating issues of sexual, racial, class and national difference with feminist theory, questions regarding religious difference have remained relatively unexplored. (Mahmood 2005: 1)

Deeper elaborations on how exactly religion(s) could and should be understood and applied in intersectional analyses are nevertheless pretty much lacking. The Swedish theologian Erica Appelros is one of the few who argues that religion is often a relevant dimension in intersectional analyses. She introduces the concept of 'religious proximity' as a tool to facilitate a more complex analysis of situations where a religious dimension interacts with other dimensions (Appelros 2005). Like Appelros, I have analysed religion as a possible category in intersectional analysis, after taking critical distance from some of the ways intersectionality has been theorised (Vuola 2012a and 2015b). ${ }^{8}$

Leslie McCall makes a distinction between different methodological approaches in intersectional analysis. Even though she does not mention religion, I find her intra-categorical approach (McCall 2005) a possible analytical tool to understand religion in the context of intersectional theorizing better. Religion and religious practices should not

\footnotetext{
${ }^{7}$ Recently also able-bodiedness, trans and cis, and queer perspectives.

${ }^{8}$ In Vuola 2012a, I analyse intersectionality in two contexts, Latin American studies and study of religion, and take an example of the cross-reference of these from my ethnographic research among Costa Rican Catholic women. The article has been translated and published also in Portuguese as 'Interseccionalidade na América Latina? As possibilidades da análise interseccional nos estudos latino-americanos de religião.' Estudos feministas e religião: tendências e debates. Eds. Sandra Duarte de Souza \& Naira Pinheiro dos Santos. Prisma: Curitiba 2014, 15-38.
} 
be interpreted only in relation to secular societies and their norms. Gender asymmetries legitimised by religion and practices within religions should also be seen as important objects of analysis. Both should be done simultaneously (Vuola 2012a: 142-143).

\section{FEMINIST THEOLOGY AND INTERSECTIONALITY}

The idea and experiences of simultaneous and multiple oppressive structures is obviously much older than feminist theology and intersectionality, and had been expressed by feminists of racial minorities in the United States and elsewhere. What Crenshaw did was to introduce the problem under a single term into contemporary feminist theory. My point is that what is largely represented by the term as presented by Crenshaw was originally theorised by feminist theologians, without any crucial difference to Crenshaw's understanding of the term, except that feminist theologians had religion at the centre of their scholarly interest. Thus, there is both similarity and difference to Crenshaw's view.

Rather than downplaying the importance and originality of Crenshaw, I wish to point to two interrelated problems. First, religion as a complex phenomenon has been downplayed in feminist theory, as I have argued throughout the article. Second, fields that do have religion as their focus, such as feminist theology and more broadly, feminist studies of religion, have not been recognised as key fields of feminist theorising. If they were acknowledged as key fields, it would most likely be commonly understood that intersectionality was first explicitly theorised within the feminist study of religion.

For example, the Catholic feminist theologian Rosemary Radford Ruether, possibly the most influential feminist theologian of all time, wrote already in 1975:

(...) any women's movement which is only concerned about sexism and no other form of oppression, must remain a women's movement of the white upper class, for it is only this group of women whose only problem is the problem of being women, since, in every other way, they belong to the ruling class. (...) Thus it seems to me essential that the women's movement reach out and include in its struggle the interstructuring of sexism with all other kinds of oppression, and recognize a pluralism of women's movements (...). (Ruether 1975: 125, emphasis in the original)

Feminist theology has been and is interreligious, ecumenical, and global, which I will illustrate in the next section. This has meant that the voices and critiques of women from the global south - Asia, Africa and Latin America - were included in feminist theology quite early. The ecumenical and interfaith organisations offered a concrete network of collaboration and mutual critique among feminist theologians from different parts of the world in the 1960s and 1970s (Vuola 2016: 316). Feminist theologians from the south have emphasised community, including the religious community, issues of poverty, and the variations of local forms of patriarchal attitudes. The legacy and influence of colonialism is intimately tied to all kinds of feminist analyses from the global south, including theology. The insights of postcolonial theory bear a greater weight for scholars from colonialized contexts (e.g., see contributors to Donaldson et al., eds. 2002). According to Ruether, in the US context:

(...) racism and sexism have been closely interrelated historically, especially in the American South, but they have not been exactly parallel. Rather, we should recognize them as interstructural elements of oppression within the overarching system of white male domination. But this interstructuring of oppression by sex, race, and also class, creates intermediate tensions and alienations - between white women and black women, between black men and white women, and even between black men and black women. (Ruether 1975: 116).

Earlier, Ruether had taken different forms of oppression as her explicit starting point (Ruether 1972). In addition to sexism and racism, Christian antisemitism and ecological issues have since been the focus of her work. In her books and articles, she analyses gender, class issues, racism, colonialism, antisemitism, and ecology as interconnected forms of oppression and marginalization (see also Ruether 1982: 52-54).

At the aforementioned conference at Harvard, Ruether described how her feminism grew out of her experiences as a white woman in the civil rights movement in the mid-1960s:

For me, those early experiences in the civil rights movement (...) were very formative in grounding my understanding of feminist theology as situated in an interconnected class, race, and gender analysis. (...) I think it has been largely misinterpreted or forgotten by feminists in the academy and theological schools who began their work in the 1980s or 1990s (...). This scenario violates and indeed erases my own experience and that of a cohort of other feminist theologians (such as Letty Russell and Beverley Harrison) who began our work in the late 1960s and early 1970s. (Ruether in Braude, ed. 2004: 73-74) 
Interestingly, in this she is part of a long history of American feminism, which started in the late $19^{\text {th }}$ century as part of the abolitionist movement. Both white and black women used religion as a base to argue against racism and sexism. In the two quotations, Ruether uses the terms interstructuring, interconnectedness, and interrelatedness of different forms of oppression; this should be recognised as a form of intersectional thinking before the term itself was coined. In other words, if we are interested in how the term came about in the context of American feminism, we should remember the intellectual legacy of early feminist theologians such as Ruether, in addition to influential black feminist thinkers.

In the same essay, Ruether also points out that 'it was not race, class and global awareness, but gender analysis that was not welcome in the circles that had mentored me in critical consciousness' (ibid.: 76). She refers here to the birth of black and Third World liberation theologies, to which I will turn later in the article. Similar quotations are found in Ruether's writings on the interstructuring and interrelatedness of different forms of experienced marginalisation and oppression. In fact, I would argue ${ }^{9}$ that the understanding of what is today called intersectionality, namely the overlapping and interrelatedness of different categories, is the most important overall theme in her thinking.

Other early feminist theologians share Ruether's understanding. For example, in one of the very first collections of feminist theology from 1979, ${ }^{10}$ the editors, Carol Christ and Judith Plaskow, say: ' (...) this dualistic pattern has been adapted to the oppression of other groups, including Jews and blacks, who, like women, are seen as more carnal and irrational than the dominant men' (Christ and Plaskow, eds. 1979: 5). It is noteworthy that this collection, possibly the very first in feminist theology, includes articles by Christian, Jewish, and Goddess (feminist postChristian and post-Jewish spirituality) theologians, or, in the case of the latter, thealogians, as they later called themselves (theos=god, thea $=$ goddess, Gr.).

Another first-generation feminist theologian, Elisabeth Schüssler Fiorenza, writes:

In the 1970s, so another story goes, White middle-class western wo/men ${ }^{11}$ had a monopoly on feminism and articulated feminist theology in the interests of elite White wo/men only, whereas in the 1980s wo/men of color assumed power and unseated White feminist theology with womanist, mujerista, or Third World wo/men's theology. (...) such progressivist replacement tales are not only misleading and prejudicial, but also do not square with the actual historical situation of feminism in the academy and in religious institutions (...) nor do they square with the theoretical conceptualization and intention of most feminist work in the 1970s. (...) such a progressivist conceptualization of feminist history overlooks the fact that the wo/men's liberation movement emerged in the context of the free speech, civil rights, Third/Fourth World liberation, and the antiwar movements of the 1960s. (Fiorenza in Braude, ed. 2004: 137-138).

Interestingly, Fiorenza's critique of the narrative of the history of feminist theology entails a similar critique of progress as Clare Hemmings' critique of secular feminist theory, discussed earlier.

Womanist theology (black feminist theology, see e.g., Cannon 1988, Grant 1989) and mujerista theology (Latina/Hispanic feminist theology, see e.g., Isasi-Díaz and Tarango 1988) emerged as critical reactions to black theology in both the United States and southern Africa, Latin American liberation theology and white feminist theology. Womanist theologians built on the already existing analysis of the interstructuring of race and gender in their critique of the sexism in black theology and liberation theology of their time. Womanist theologians differed from other feminist theologians in their more positive assessment of the Christian tradition: the black churches and African-American spirituality, as expressed for example in negro spirituals, were important and positive sources of community, identity, and hope during slavery and afterwards. In this sense, it is no surprise that some of the most important black leaders in both the United States and South Africa have been priests, such as Dr. Martin Luther King, Jr. and Desmond Tutu. ${ }^{12}$

However, as Kwok Pui-lan reminds us, it is incorrect to present the resurgence of different forms of feminist theology as a lineage from white feminist theology to its 'derivations'. According to her:

When describing this diverse and multifaceted theological movement [feminist theology], scholars tend to give primacy to the contributions of women of European descent. They are considered 'fore-mothers' who have laid the foundation of the discipline, upon which others can build. The assumption is that

\footnotetext{
${ }^{9}$ I wrote my Master's thesis in the mid-1980s on Ruether's thinking and have read practically all her publications ever since. My dissertation (Vuola 2002) deals with the differences and similarities between feminist theology and Latin American liberation theology.

${ }^{10}$ A European volume of feminist theology came out the same year. See Halkes and Buddingh (eds.) 1979.

11 Through this term (wo/men) Fiorenza, at some point, started to refer not only to women but also to disadvantaged men.

${ }^{12} \mathrm{I}$ am not aware of such research which would look at the role of religion, especially in its positive aspects, for the development of American black feminism, which is also the intellectual background of thinkers such as Crenshaw.
} 
white feminist theology appeared first on the scene, and its emergence made possible the development of black women's theology, Hispanic women's theology and various Third World feminist theologies. Such a reading is not only Eurocentric, it also mystifies and obscures the profoundly intercultural character of feminist theology. I want to argue that feminist theology is not only multicultural, rooted in multiple communities and cultural contexts, but is also intercultural because these different cultures are not isolated but intertwined with one another as a result of colonialism, slavery, and cultural hegemony of the West. (Kwok 2002: 24-25)

According to Kwok, the different forms of feminist theology around the world have stressed the differences among women, and intense debates around the politics of identity have taken place. She notes:

Although these discourses [on difference] have their own history and institutional sites, they are not isolated but often overlap with one another. The first discourse emerged in the late 1970s and early 1980s when (...) womanist theologians spoke about the 'multiple oppression' or 'triple jeopardy' of black women (Kwok 2002, 30).

\section{GLOBAL LIBERATION THEOLOGY, THE ECUMENICAL MOVEMENT AND FEMINISM}

In this section, I will look at some institutional sites, mentioned above by Kwok, and the related specific history of feminist theology, which may help us understand how the early inclusion of different forms of oppression came about in feminist theology.

The early emphasis of feminist theologians from both the global north and the global south on the interstructuring systems of power and oppression in relation to religion was an outcome of their collaboration with a global theological movement that could be broadly called liberation theology. In the narrow sense, the term refers to Latin American liberation theology (teologia de la liberación); in the broader sense, it refers to different kinds of contextualised theologies aimed at an analysis of the interplay of religion with sexism, racism and colonialism. In the 1980s, there were already Asian and African liberation theologies, black theology in both South Africa and the United States, and feminist theologies in all those contexts.

Liberation theology, born in the 1970s, was in the broad sense a reaction to the role which especially Christianity had held in the areas colonised by Europe, and its long-standing effects such as chronic poverty. ${ }^{13}$ What is relevant here for my argument about feminist theology is the existence of feminist liberation theology (see, for example, Fiorenza 1975), which has had multiple expressions and forms. First-generation North American feminist theologians, such as Rosemary Ruether and Elizabeth Schüssler Fiorenza, in fact named their theology feminist liberation theology. The very term points to the broader agenda of the interstructuring of different forms of oppression and the necessity of feminist analysis of all of them.

Feminist liberation theologians were practically and conceptually linked to liberation theology, which was a theoretical, practical and political movement mainly in the global south. Colonialism and its far-reaching consequences as well as religion became crucial 'intersections' of feminist theology of the 1970s. For this reason, the feminist theological 'interstructuring' was in fact not only earlier, but also broader and more global in its approach than intersectionality in the 1990s. By global, I here refer to feminist analyses in different geopolitical contexts and parts of the world, by local thinkers, but also to the explicit inclusion of an analysis of colonialism and global economic injustice as an essential part of feminist critique.

Connections to this global movement of liberation theologies influenced feminist theology especially as they were practised and theorised in the Ecumenical Association of the Third World Theologians (EATWOT) that was founded in 1976. It was a forum of Christian theologians from all over the world, which focused on changes not only in theology, but also in the churches and society. In the context of EATWOT, a global, feminist liberation theological paradigm was created, that included feminist theologians from Asia, Africa, Latin America, and the global north.

Different liberation theologies have influenced each other since the 1970s. Latin American liberation theologians were criticised for avoiding race and ethnicity issues. Black theologians were criticised for a lack of class analysis. Asian and African liberation theologians brought perspectives from multi-ethnic and multi-religious contexts. Most feminist theologians agree that the gender perspective - women, for them - was the last to be included in the liberation theological agenda. According to them, feminism needs to be understood broadly, not only as a struggle against sexism, but also 'against racism, classism, colonialism and militarism as structures of women's exploitation and oppression’ (Fiorenza 1989: 316). For most feminist theologians from the global south,

\footnotetext{
${ }^{13}$ Even though liberation theology has been a primarily Christian phenomenon, there are similar liberation theologies in other religious traditions, especially in Islam and Judaism.
} 
as well as for the womanist and mujerista theologians in the United States, this interstructuring of oppressions was their explicit starting point. ${ }^{14}$

A collection of Third World feminist theology from 1988 edited by Russell, Kwok, Isasi-Díaz and Cannon includes entries mostly from scholars who have their origins outside the United States, but have conducted their academic career there. Thus, there has been dialogue not only among white feminist, womanist, and mujerista theologians within the United States or liberation theologians of all sorts from various parts of the world, but also among theologians from racial and ethnic minorities in the USA and feminist theologians from the global south.

EATWOT was founded in 1976 in Dar-es-Salaam, Tanzania and regular global and regional conferences followed. ${ }^{15}$ EATWOT and its conferences have been crucial in the creation of not only liberation theology in the broad sense, but also of global feminist theology. In the reports of the first two conferences (Torres et al., eds. 1978; Appiah-Kubi et al., eds. 1979), women, sexism or feminism are not mentioned. It was only at the third conference of EATWOT in Sri Lanka in 1979 that the issue explicitly emerged (contributors to Fabella, ed. 1980; see especially, Katoppo 1980), and it has been on the agenda ever since.

At the conference of New Delhi in 1981, feminist theological issues gained force (contributors to Fabella et al., eds. 1983). One of the driving forces, Mercy Amba Oduyoye from Ghana termed the voice of feminists from the global south as the 'irruption within the irruption', referring to the theme of the New Delhi conference, which was Irruption of the Third World (Oduyoye 1983: 247). She writes:

Issues of sexism are supposed to belong to a minority of disgruntled, leisure-saturated, middle-class women of the capitalist West. (...) The fact is that sexism is part of the intricate web of oppression in which most of us live, and that having attuned ourselves to it does not make it any less a factor of oppression. Most Third World women, being literally close to the earth and to the maintenance of their race against classist and racist aggression, have opted to find complete fulfillment in this sacred duty and why not? But that does not mean an approval of sexism. (...) Feminism is anything but the imperialist ploy some would like us to take it for. (Oduyoye 1983: 249)

An important conference from the feminist theological perspective was that organised in Geneva in 1983 which focused on the dialogue between First World and Third World liberation theologians. ${ }^{16}$ (Fabella et al., eds. 1985). There had been earlier similar conferences in Detroit in 1975 and 1980, but they had concentrated on the Americas (Torres et al., eds. 1976).

A women's commission of EATWOT was created in 1983; after that, women held international and regional meetings. The first was held in Oaxtepec, Mexico in 1986, and the resulting book is the first compilation of feminist theological thinking from Africa, Asia, and Latin America (contributors to Fabella et al., eds. 1988; Ruether 2002: 14-18; see also contributors to King, ed. 1994). In the introduction to the book, which contains the papers held at the meeting, the editors state:

The context of poverty, multiple oppression, and tokenism shows up as a common experience of all the three continents. The Third World is a cross-ridden universe of economic, political, and religious-cultural oppressions within which women are doubly or triply burdened (Fabella et al. 1988: xi). ${ }^{17}$

Besides EATWOT, the ecumenical movement in general, especially the World Council of Churches (WCC) ${ }^{18}$ as well as interfaith organisations have been key factors in the early development of both feminist theology and liberation theology globally, including black theology in the USA, Africa, and Latin America. Detailed research on the subject has not yet been done, as far as I know (see however, King 1994: 8-12). According to Elisabeth Raiser:

The process of transforming the ecumenical community of churches into a truly 'inclusive' community gained momentum during the 1960s. Often ecumenical endeavours in this respect ran parallel to political

\footnotetext{
${ }^{14}$ See also the articles in Mission Trends 4 (1979), edited by G. H. Anderson and T. F. Stransky, on one of the early compilations of different forms of liberation theologies and critical dialogue between them, including feminist critique.

${ }^{15}$ Conferences have been held in Dar-es-Salaam, Tanzania (1976), Accra, Ghana (1977), Wennappuwa, Sri Lanka (1979), São Paulo, Brazil (1980), New Delhi, India (1981), Geneva, Switzerland (1983), Oaxtepec, Mexico (1986), Nairobi, Kenya (1992), Tagaytay, Philippines (1996), and Quito, Ecuador (2001).

${ }^{16}$ Feminist theologians such as Rosemary Ruether, Letty Russell, Elsa Tamez, Mercy Amba Oduyoye, and Dorothee Sölle were present.

17 The women's conference preceded the general assembly of EATWOT in Mexico in 1986. A collection on the commonalities and divergences between different forms of liberation theology, including feminist theology, brings together the papers presented at the general conference (Abraham, ed. 1990).

${ }_{18}$ The WCC is the largest and most encompassing formal organization of cooperation between Christian churches, although the Catholic Church is not a formal member.
} 
struggles for liberation and participation, and were inspired by the anti-apartheid and civil-rights movements, and not least by the emerging women's movement. (Raiser 2004: 243)

This demand for greater inclusivity did not occur without conflicts, and women's participation and critique became the touchstone of inclusivity in the ecumenical work. Tensions arose not only from the patriarchal structures of various member churches, but also in connection with different issues raised by women from the south and the north (Raiser 2004: 243-245). Thus, the WCC became one important forum for a global feminist dialogue, and it should not be overlooked: rather than focusing merely on the fact that this dialogue happened within and among Christian churches, it is important to acknowledge the transnational and global character of this specific history of dialogue between feminists. A department of Women in Church and Society was established within the WCC in 1971. Feminist theologians from the global south, such as Mercy Amba Oduyoye from Ghana and Aruna Gnanadason from India, became prominent ecumenical and international leaders. ${ }^{19}$

The processes within EATWOT and WCC were partly parallel and also influenced each other. As I have said earlier, this process should be studied in detail. However, at this point I would like to compare the ecumenical and interfaith process of global feminism to its secular counterpart within the United Nations. Sometimes the processes overlapped: participants in one may have also participated in the other. Especially for feminists from the global south, the two processes were not necessarily as separated from each other as for feminists from the north. The ecumenical and interfaith context provided women from the south with education (in form of scholarships to pursue doctoral studies in Europe or the USA), leadership skills and positions, funds, and an established platform for concrete cooperation and dialogue. ${ }^{20}$ Another global process, again partly parallel, that has been significant for various forms of feminist interpretations of religion, is that of interreligious consultations, dialogues, and organisations. Within them, the transnational dialogue of women from Christian churches expanded to dialogues between feminists from different religious traditions (see, e.g., Egnell 2006; Eck et al., eds. 1986).

These histories need to be researched and told. Not only because they de facto are part of the history of feminism and feminist theorising, but also because they reveal how the relationship between religion, women and feminism, is far from simplistic and monolithic. For many women, their religion is both a source of oppression and empowerment, and not to pay attention to both, is historically and conceptually inaccurate.

\section{CONCLUSION}

My article is an example of not only a critical re-reading of the history of feminist theorising, but also a critique of the epistemic habits of academic feminism and its relation to feminist knowledge production. Following Clare Hemmings' insistence on paying attention to the exclusionary aspect of the historical record of academic feminism, I have highlighted an excluded body of work, that of feminist studies of religion, especially global feminist theology.

I have argued that key concepts such as intersectionality have been theorised in feminist theology earlier than possibly in any other field of feminist research due to the close cooperation of feminist theologians with liberation theologians from the global south. I also presented sketches for a history of feminist theorising from a fresh perspective, that of ecumenical, interfaith, and global feminist dialogue.

As I said in the beginning, it is beyond the scope of this article to analyse how theories of intersectionality, since Crenshaw, have been received and developed in later feminist theology. A short survey of some general presentations of feminist theology and gender studies in religion, seems to suggest that intersectionality as a term has not been used (see, e.g., Beattie 2005; Clague 2005; Hawthorne 2005; King 2005). This may be a continuation of the meagreness of explicit dialogue between feminist theology and secular gender theories, which has also been pointed out by others (e.g., Eriksson 1995; Stenström et al. 2007; Tsokkinen 2008; Vuola 2002: 118-123; Vuola 2007). In a collection of feminist theological essays from 2014, intersectionality is mentioned but not elaborated on (Lipsett et al., eds. 2014). Schüssler Fiorenza discusses intersectionality briefly in her recent book (Fiorenza 2011: 7-11).

To conclude, I offer some further remarks on how the inclusion of religion would broaden our focus of intersectionality. It is both important and possible to treat religion intersectionally as a producer of 'difference' among women as well as to analyse religion as a cross-cutting element within other differences, identity categories

\footnotetext{
${ }^{19}$ Several of the feminist theologians writing in Russell et al., (eds.) 1988 recognise the influence of EATWOT, WCC and other ecumenical networks for them. Many of them have worked or been active in one or another ecumenical organisation. For a recent European perspective on similar developments, see Walton 2016, 289. The concrete financial and other type of support from the ecumenical movement for the education of feminist theologians from the global south should be researched. There are several women theologians from Africa, Asia, and Latin America who have been able to pursue their doctoral studies abroad because of scholarships granted to them by the WCC and other ecumenical organisations.

${ }^{20}$ The WCC has also been crucial in developing theological education and research in the global south, yet another area in need of further research.
} 
and power asymmetries. However, it is imperative to distinguish between different aspects of religion - the institutional, cultural, ethical, doctrinal, and spiritual - in order to avoid reducing any religious tradition to a single aspect. If the concept of intersectionality is used as a theoretical tool to create more dialogue between gender studies in religion and other fields of feminist theorising, it should be applied both internally and externally. By this I mean that internal power asymmetries related to gender, race, and ethnicity, should be analysed carefully within each religious tradition, including women's interpretations (both academic and lived) of them. Externally, religion as a category in all its aspects would be considered in intersectional analyses when relevant. I would claim that it is relevant in most - if not all - cultures.

A broad and inclusive understanding of religion as well as research with different methods is essential. Secular feminism in its critique and avoidance of religion, and feminist theology in its critique of religions, have concentrated on the formal, institutional aspects of religion. This is understandable and necessary, but it is not enough: women negotiate with their religious communities and identities in multiple ways (see for example contributors to Gemzöe et al., eds. 2016). The approach of lived religion (for example, Hall, ed. 1997; McGuire 2008; Orsi 2002) pays attention to religion and everyday life, gender, body, and materiality - that is, ordinary women's and men's ways of living and reflecting on their religiosity. The lived religion approach has been primarily developed within religious studies, not theology or anthropology. In my view, for a further development of the approach, more multidisciplinary research is needed, in order to understand the interplay of religious institutions, their teachings and ordinary people's interpretations of them.

It is essential that scholars pay attention to sexist interpretations and practices within religions, but this should be made in relation to women's religious and other agency. In intersectional analyses, this means seeing religion not only as a 'difference' between women (of different cultures and religions, and within a given religious tradition and society), but also seeing gender as an intersectional category in the study of religion. This makes it possible to understand religion as both a structure of power and a source of empowerment and positive identity (Vuola 2012a: 142-143; Vuola 2015b: 42-45).

For any feminist analysis, it is crucial that religious women are seen in terms of their agency, including their critical or non-traditional assessment of their religious traditions. It may be that theories of intersectionality prove to be the most fruitful ways to create more dialogue between the study of religion and feminist theorizing, minimising the, until now, too-narrow understanding of religion. Obviously, it means detailed analyses of religion and gender in different cultural, political, and social contexts, as well as in different religious traditions to avoid monolithic interpretations of the complex category of religion.

It remains to be seen if intersectionality as theorised primarily in the global north is a suitable framework also for feminist theorizing in the global south. The term has been used globally in development and human rights discourses and practices, but it is important to take into account of the fact that in spite of its history it is still a concept created in the global north, especially in the United States. It is clear that the inclusion of issues of race, class, and ethnicity in relation to gender has been effectively developed by feminists in the global south well before the term intersectionality was coined. The analytical logics behind intersectionality have been present in feminist theology and feminist critiques in the global south before it became a 'buzzword' in contemporary feminist theory. I myself have discussed the possibilities of the use of the term in the context of Latin America (Vuola 2012a), taking into account both religion and the specific intellectual history of the region. Whether these specific forms of feminist thinking are called intersectional or not is a matter of definition. The critical purchase lies in recognising and analysing different forms of oppression and how they overlap, and this insight is not dependent on whether this particular word is used or not.

The vast debate between universality and cultural relativism as it is related to gender issues and women's rights is still - or even increasingly - important for gender studies and feminism. It is central to any feminist project, theoretical or practical, to take into account that the potential dangers of cultural relativism or cultural essentialism are as important as the dangers of universalism. This issue is directly related to the ways we understand and use the concept of intersectionality. For example, according to Uma Narayan:

The project of attending to differences among women across a variety of national and cultural contexts becomes a project that endorses and replicates problematic and colonialist assumptions about the cultural differences between 'Western culture' and 'Non-western cultures' and the women who inhabit them. Seemingly universal essentialist generalizations about "all women" are replaced by culture-specific essentialist generalizations that depend on totalizing categories such as 'Western culture', 'Non-western cultures', 'Western women', 'Third World women', and so forth. (Narayan 2000, 81, emphasis in original)

For her, in a way that is similar to gender essentialism, cultural essentialism assumes and constructs sharp binaries, and in both cases, the discursive reiteration of essential differences often operates to conceal their role in the production and reproduction of such 'differences' (ibid.: 82). She emphasises the importance of paying attention to internal plurality, dissension, and contestation over values and ongoing changes within any category 
(nation, religion, gender, etc.) - which is not to deny the existence of differences per se (ibid.: 96). Narayan theorizes from within a postcolonial feminist context, which is why her critique has relevance not only to theories of intersectionality in general, but especially to feminist theorising in the global south.

The importance of my argument in this article lies in its contribution to the historiography and ways of exclusion in contemporary feminist theory. It is not only the aspect of religion and theology that I highlight, but also their global character, as expressed in feminist theological cooperation in ecumenical and transnational contexts. Looking forward, the importance of understanding feminist de- and re-constructions of religion in different cultural contexts lies in its potential to counter what I have called patriarchal ecumenism (Vuola 2009: 227-229). The growing cooperation and alliance among Catholic, Protestant, Orthodox, and Muslim conservative sectors on issues of sexuality, family, and gender, can be countered only with an adequate understanding of each religious tradition. A feminist critique and possible reinterpretation of religion from within those traditions is more credible and powerful than a secularist, anti-religious, feminist critique, which is easy to be dismissed because of its oftenunfortunate lack of acknowledgement of religion in general, and different religious traditions in particular. This recognition is especially crucial in societies in which hegemonic religions have (growing) influence on legislation. Even in Western Europe, it is more crucial than ever to be able to argue that feminism and religion are not necessarily and always opposing forces: that feminism does not equal secular and anti-religion. Politically, then, it is important to show how religion and feminism have positively interacted in different times and in different contexts, and that such a feminist critique of religion which is based on the ability to read and interpret its sacred texts, dogma, teachings, and symbolism, is possibly the best method to achieve such an understanding.

\section{REFERENCES}

Abraham, K.C. (ed.) (1990). Third World Theologies. Commonalities and Divergences. New York: Orbis Books.

Ahmed, L. (1992). Women and Gender in Islam. Historical Roots of a Modern Debate. New Haven: Yale University Press. Appelros, E. (2005). Religion och intersektionalitet. Kvinnovetenskaplig tidskrift, 2-3, pp. 69-80.

Appiah-Kubi, K. and Torres, S. (eds.) (1979). African Theology en Route. New York: Orbis Books.

Beattie, T. (2005). Feminist Theology: Christian Feminist Theology. In: L. Jones, ed. in chief, Encyclopedia of Religion (pp. 3034-3039). 2nd ed. Vol. 5. Detroit: Thomson Gale.

Brah, A. and Phoenix, A. (2004). Ain't I A Woman? Revisiting Intersectionality. Journal of International Women's Studies, 5(3), pp. 75-86.

Braidotti, R. (2008). In Spite of the Times. The Postsecular Turn in Feminism. Theory, Culture and Society, 25(6), pp. $1-24$.

Braude, A. (2001). Radical Spirits. Spiritualism and Women's Rights in Nineteenth-Century America. Second edition. Bloomington and Indianapolis: Indiana University Press.

Braude, A. (2004). Introduction. In: A. Braude, ed., Transforming the Faiths of Our Fathers. Women Who Changed American Religion (pp. 1-11). New York: Palgrave Mac Millan.

Braude, A. (ed.) (2004). Transforming the Faiths of Our Fathers. Women Who Changed American Religion. New York: Palgrave MacMillan.

Brekus, C.A. (2007). Introduction: Searching for Women in Narratives of American Religious History. In: C.A. Brekus, ed., The Religious History of American Women. Reimagining the Past (pp. 1-50). Chapel Hill: The University of North Carolina Press.

Cannon, K.G. (1988). Black Womanist Ethics. Atlanta: Scholars Press.

Casanova, J. (1994). Public Religions in the Modern World. Chicago: University of Chicago Press.

Castelli, E. (2001). Women, Gender, Religion: Troubling Categories and Transforming Knowledge. In: E. Castelli, ed., Women, Gender, Religion: A Reader (pp. 3-25). New York: Palgrave MacMillan.

Christ, C. and Plaskow, J. (eds.) (1979). Womanspirit Rising. A Feminist Reader in Religion. San Francisco: Harper \& Row.

Clague, J. (2005) Women's Studies in Religion. In: L. Jones, ed. in chief, Encyclopedia of Religion (pp. 9785-9796). 2nd ed. Vol. 14. Detroit: Thomson Gale.

Crenshaw, K. (1989). Demarginalizing the Intersection of Race and Sex. A Black Feminist Critique of Antidiscrimination Doctrine, Feminist Theory and Antiracist Politics. University of Chicago Legal Forum, pp. 139167.

Crenshaw, K. (1991). Mapping the Margins. Intersectionality, Identity Politics, and Violence against Women of Color. Stanford Law Review, 43(6), pp. 1241-1299.

Davis, K. (2008). Intersectionality as buzzword: A sociology of science perspective on what makes feminist theory successful. Feminist Theory, 9(1), pp. 67-85.

Donaldson, L. and Kwok P.-L. (eds.) (2002). Postcolonialism, Feminism, and Religious Discourse. New York: Routledge. 
Eck, D. and Jain, D. (eds.) (1986). Speaking of Faith. Cross-Cultural Perspectives on Women, Religion, and Social Change. London: The Women's Press.

Egnell, H. (2006). Other Voices. A Study of Christian Feminist Approaches to Religious Pluralism East and West. Uppsala: Swedish Institute of Mission Research.

Eriksson, A.-L. (1995). The Meaning of Gender in Theology: Problems and Possibilities. Stockholm: Almqvist och Wiksell International.

Fabella, V. (ed.) (1980). Asia's Struggle for Full Humanity. Towards a Relevant Theology. New York: Orbis Books.

Fabella, V. and Oduyoye, M.A. (1988). Introduction. In: V. Fabella and M.A. Oduyoye, eds., With Passion and Compassion. Third World Women Doing Theology (pp. ix-xv). New York: Orbis Books.

Fabella, V. and Oduyoye, M.A. (eds.) (1988). With Passion and Compassion. Third World Women Doing Theology. New York: Orbis Books.

Fabella, V. and Torres, S. (eds.) (1983). Irruption of the Third World. Challenge to Theology. New York: Orbis Books.

Fabella, V. and Torres, S. (eds.) (1985). Doing Theology in a Divided World. New York: Orbis Books.

Fiorenza, E. (1975). Feminist Theology as a Critical Theology of Liberation. Theological Studies, 36, pp. 605-626.

Fiorenza, E. (1989). The Politics of Otherness: Biblical Interpretation as a Critical Praxis of Liberation. In: M.H. Ellis and O. Maduro, eds., The Future of Liberation Theology. Essays in Honor of Gustavo Gutierrez. (pp. 311-325). Second edition. New York: Orbis Books.

Fiorenza, E. (2011). Transforming Vision. Explorations in Feminist The ${ }^{*} \log$. Minneapolis: Fortress Press.

Gemzöe, L., Keinänen, M.-L. and Maddrell, A. (eds.) (2016). Contemporary Encounters in Gender and Religion. European Perspectives. New York: Palgrave MacMillan.

Grant, J. (1989). White Women's Christ and Black Women's Jesus. Feminist Christology and Womanist Response. Atlanta: Scholars Press.

Halkes, C. and Buddingh, D. (eds.) (1979). Wenn Frauen ans Wort kommen. Stimmen zur feministischen Theologie. Berlin: Gelnhausen.

Hall, D. (ed.) (1997). Lived Religion in America. Toward a History of Practice. Princeton: Princeton University Press.

Hammar, I. (1998). Några reflexioner kring 'religionsblind' kvinnoforskning. Historisk tidskrift, 1.

Hammar, I. (2010). From Fredrika Bremer to Ellen Key: Calling, Gender and the Emancipation Debate in Sweden, c. 1830-1900. In: P. Markkola, ed., Gender and Vocation. Women, Religion and Social Change in the Nordic Countries, 1830-1940 (pp. 27-67). Helsinki: Finnish Literature Society.

Hawthorne, S. (2005). Feminism, Gender Studies, and Religion. In: L. Jones, ed. in chief, Encyclopedia of Religion (pp. 3023-3027). 2nd ed. Vol. 5. Detroit: Thomson Gale.

Hemmings, C. (2005). Telling Feminist Stories. Feminist Theory, 6(2), pp. 115-139.

Hemmings, C. (2011). Why Stories Matter. The Political Grammar of Feminist Theory. Durham \& London: Duke University Press.

Isasi-Díaz, A.M. and Tarango, Y. (1988). Hispanic Women. A Prophetic Voice in the Church. New York: Harper \& Row.

Katoppo, H. (1980). Asian Theology: An Asian Woman's Perspective. In V. Fabella, ed., Asia's Struggle for Full Humanity. Towards a Relevant Theology (pp. 140-151). New York: Orbis Books.

King, U. (1994). Introduction. In: U. King, ed., Feminist Theology from the Third World. A Reader (pp. 1-20). London and New York: SPCK and Orbis Books.

King, U. (2005). Gender and Religion: An Overview. In: L. Jones, ed. in chief, Encyclopedia of Religion (pp. 32963310). 2nd ed. Vol. 5. Detroit: Thomson Gale.

King, U. (ed.) (1994). Feminist Theology from the Third World. A Reader. London and New York: SPCK and Orbis Books.

Kinnunen, T. (2014). Alexandra Gripenberg's Feminist Christianity. In: T. Utriainen and P. Salmesvuori, eds., Finnish Women Making Religion. Between Ancestors and Angels (pp. 61-79). New York: Palgrave MacMillan.

Kwok, P-L. (2002). Feminist Theology as Intercultural Discourse. In: S.F. Parsons, ed., The Cambridge Companion to Feminist Theology (pp. 23-39). Cambridge: Cambridge University Press.

Lipsett, B.D. and Trible, P. (eds.) (2014). Faith and Feminism. Ecumenical Essays. Louisville: Westminster John Knox Press.

Ludvig, A. (2006). Differences between Women? Intersecting Voices in a Female Narrative. European Journal of Women's Studies, 13(3), pp. 245-258.

Lykke, N. (2003). Intersektionalitet - ett användbart begrepp för genusforskningen. Kvinnovetenskaplig tidskrift, 1, pp. 47-56.

Lykke, N. (2005). Nya perspektiv på intersektionalitet. Problem och möjligheter. Kvinnovetenskaplig tidskrift, 2-3, pp. 7-17.

Mahmood, S. (2005) Politics of Piety. The Islamic Revival and the Feminist Subject. Princeton: Princeton University Press.

McCall, L. (2005). The Complexity of Intersectionality. Signs, 3(30), pp. 1771-1800.

McGuire, M.B. (2008). Lived Religion. Faith and Practice in Everyday Life. New York: Oxford University Press. 
Narayan, U. (2000). Essence of Culture and a Sense of History: A Feminist Critique of Cultural Essentialism. In: U. Narayan and S. Harding, eds., Decentering the Center. Philosophy for a Multicultural, Postcolonial, and Feminist World (pp. 80-109). Bloomington: Indiana University Press.

Nash, J.C. (2008). Re-thinking intersectionality. Feminist Review, 89, pp. 1-15.

Oduyoye, A. (1983). Reflections from a Third World Woman's Perspective: Women's Experience and Liberation Theologies. In: V. Fabella and S. Torres, eds., Irruption of the Third World. Challenge to Theology (pp. 246-255). New York: Orbis Books.

Orsi, R.A. (2002). The Madonna of the 115th Street. Faith and Community in Italian Harlem, 1880-1950, 2nd ed. New Haven: Yale University Press.

Raiser, E. (2004). Inclusive Community. In: J. Briggs, M.A. Oduyoye and G. Tsetsis, eds., A History of the Ecumenical Movement, Vol. 3, 1968-2000 (pp. 243-277). Geneva: World Council of Churches.

Ruether, R. (1972). Liberation Theology. Human Hope Confronts Christian History and American Power. New York: Paulist Press.

Ruether, R. (1975). New Woman, New Earth. Sexist Ideologies and Human Liberation. San Francisco: Harper \& Row.

Ruether, R. (1982). Disputed Questions: On Being a Christian. Nashville: Abingdon.

Ruether, R. (2002). The Emergence of Christian Feminist Theology. In: S.F. Parsons, ed., The Cambridge Companion to Feminist Theology (pp. 3-22). Cambridge: Cambridge University Press.

Russell, L., Kwok P.-L, Isasi-Díaz A.M. and Cannon K.G. (eds.) (1988). Inheriting Our Mothers' Gardens. Feminist Theology in Third World Perspective. Louisville: The Westminster Press.

Stenström, H. and Vuola, E. (2007). Introduction. Journal of the European Society for Women in Theological Research 2007: Scandinavian Critique of Anglo-American Feminist Theology, pp. 3-13.

Torres, S. and J. Eagleson (eds.) (1976). Theology in the Americas. New York: Orbis Books.

Torres, S. and Fabella, V. (eds.) (1978). The Emergent Gospel. Theology from the Underside of History. New York: Orbis Books.

Tsokkinen, A. (2008). Etuoikeutettu sukupuoli? Käsitys auktoriteetista Elisabeth Schüssler Fiorenzan feministisessä teologiassa. Helsinki: Suomalainen Teologinen Kirjallisuusseura.

Vuola, E. (2002). Limits of Liberation. Feminist Theology and the Ethics of Poverty and Reproduction. Sheffield and New York: Sheffield Academic Press and Continuum.

Vuola, E. (2006). Seriously Harmful for Your Health? Religion, Feminism, and Sexuality in Latin America. In: M. Althaus-Reid, ed., Liberation Theology and Sexuality (pp. 137-162). Aldershot: Ashgate.

Vuola, E. (2007). Study of Religion and Feminist Theory: Dialogue or Silence? Journal of the European Society for Women in Theological Research 2007: Scandinavian Critique of Anglo-American Feminist Theology, pp. 189-197.

Vuola, E. (2009). Patriarchal Ecumenism, Feminism, and Women's Religious Experiences in Costa Rica. In: H. Herzog and A. Braude, eds., Gendering Religion and Politics. Untangling Modernities (pp. 217-238). New York: Palgrave MacMillan.

Vuola, E. (2012a). Intersectionality in Latin America? The Possibilities of Intersectional Analysis in Latin American Studies and Study of Religion. In: S. Lundgren, T. Machado-Borges and C. Widmark, eds., Bodies and Borders in Latin America (pp. 131-151). Stockholm: Stockholm University and University of Gothenburg.

Vuola, E. (2012b). La Morenita on Skis. Women's Popular Marian Piety and Feminist Research on Religion. In: M. McClintock Fulkerson and S. Briggs, eds., The Oxford Handbook of Feminist Theology (pp. 494-524). Oxford and New York: Oxford University Press.

Vuola, E. (2015a). The Exclusion of (the Study of) Religion in Latin American Gender Studies. LASA Forum, XLVI(1), 17-19. http://lasa.international.pitt.edu/forum/past-issues/vol46-issue1.asp

Vuola, E. (2015b). Unohdettu ero? Intersektionaalisuus, naiset ja uskonto. In: J. Ahonen and E. Vuola, eds., Uskonnon ja sukupuolen risteykesiä (pp. 32-54). Helsinki: Suomalaisen Kirjallisuuden Seura.

Vuola, E. (2016). Feminist Theology, Religious Studies and Gender Studies: Mutual Challenges. In: L. Gemzöe, M.-L. Keinänen and A. Maddrell, eds., Contemporary Encounters in Gender and Religion. European Perspectives (pp. 307-334). New York: Palgrave MacMillan.

Walker, Alice (1983). In Search of Our Mothers' Gardens: Womanist Prose. New York: Harcourt, Brace \& Jovanovich.

Walton, H. (2016). The History of Feminist Theology in the Academy: An Autoethnographic Research Journey. In: L. Gemzöe, M.-L. Keinänen and A. Maddrell, eds., Contemporary Encounters in Gender and Religion. European Perspectives (pp. 285-305). New York: Palgrave MacMillan.

Yuval-Davis, N. (2006). Intersectionality and Feminist Politics. European Journal of Women's Studies, 13(3), pp. 193209. 
Citation: Vuola, E. (2017). Religion, Intersectionality, and Epistemic Habits of Academic Feminism. Perspectives from Global Feminist Theology. Feminist Encounters: A Journal of Critical Studies in Culture and Politics, 1(1), 04. https://doi.org/10.20897/femenc.201704

Copyright (C) 2017 by Author/s and Licensed by Lectito BV, Netherlands. This is an open access article distributed under the Creative Commons Attribution License which permits unrestricted use, distribution, and reproduction in any medium, provided the original work is properly cited. 
http://www.lectitopublishing.nl

https://www.facebook.com/LectitoJournals/

https://twitter.com/lectitojournals

$\mathcal{S}_{+}$https://plus.google.com/110901545130385419486

in https://www.linkedin.com/in/lectito-journals9a675010b/ 


\title{
Fluid Reading Practice: On the Queer Potential of Studying Nonhuman Animals
}

\author{
Sari Irni ${ }^{1 *}$
}

Published: October 30, 2017

\begin{abstract}
This paper contributes to recent discussions about the relevance of the natural sciences and nonhuman animals in feminist theory by drawing from feminist debates on the queer potential of studying nonhuman animals. The paper discusses readings on the intertwining of scientific accounts of nonhuman animals and politics; how different nonhuman animal bodies have enabled various conceptualisations of sex and physical intimacy and have been enmeshed in the politics of sex; and how to read the relevance of accounts of the diversity of nonhuman animal sex(es) for feminist endeavours. These discussions contribute to an exploration of 'fluid reading', a feminist reading practice which draws inspiration from and moves with both new materialisms and poststructuralisms. The paper proposes that not only mood is important in feminist reading practices but also movements and flows.
\end{abstract}

Keywords: feminist reading strategies, nonhuman animals, queer, poststructuralism, new materialism

\section{INTRODUCTION}

This paper contributes to recent discussions about the natural sciences and nonhuman animals and/in feminist theory by drawing from feminist debates on the queer potential of studying nonhuman animals. I discuss how the question of the queer potential of nonhuman animals has been drawn into debates between poststructuralist and new materialist feminisms (or material feminisms, e.g. Alaimo and Hekman 2008). These debates have been the focus of feminist theory for a while, and the importance of taking nonhuman animals into account in feminist theory has certainly been argued (Birke et al. 2004; Haraway 2008). Feminists dubbed as new materialist, mainly those inspired by the natural sciences, have noted the proliferation of poststructuralist approaches within feminist studies and argued that feminists also need to account for the 'materialization of matter', including nonhuman animals (Barad 2003; see also Birke et al. 2004; Alaimo \& Hekman 2008; Alaimo 2010; Wilson 2010, 2015; Grosz 2011; Kirby 2011). In response, cultural studies scholars have expressed concern about the ways in which natural science-based arguments have begun proliferating and about their implications for maintaining the nature-culture binary (Ahmed 2008, Sullivan 2012). Some poststructuralist scholars have argued that a focus on scientific analyses of nonhuman animals particularly are not necessary for a feminist analysis of sex:

Why, I am left wondering after having read a plethora of 'new materialist' writings, do we need to turn to 'scientific' studies of bonobos, bowhead whales, bighorn sheep, buff-breasted sandpipers, aphids, to see physical intimacy as radically diverse? Why do we need to look to bacteria (or, more correctly, to contemporary scientific perceptions of bacteria as a form of species-being) in order to envisage our 'selves' as other than singular bounded beings whose identity is innate and unchanging? (Sullivan 2012: 308)

In this paper's affective beginnings, I was both inspired and provoked by the article by Sullivan cited above, especially her way of reading the work she dubs new materialist — which I found unfair, even if I agree with many of her points (for more, see Irni 2013a). This paper, while acknowledging Sullivan's apt and important arguments, takes her article, The somatechnics of perception and the matter of the non/human (Sullivan 2012), as an example of reading in the spirit of a hermeneutics of suspicion. Felski (2015) discusses such reading habits more widely, related to the moods and modes of academic critique. The key elements of this reading habit consist of: 
a spirit of skeptical questioning or outright condemnation, an emphasis on its precarious position vis-avis overbearing and oppressive social forces, the claim to be engaged in some kind of radical intellectual and/or political work, and the assumption that whatever is not critical must therefore be uncritical (2015: 2 , emphasis in original).

This paper, then, explores my agreements and disagreements with Sullivan, both concerning nonhuman animals and the ways in which critique is put to work, particularly from the perspective of how nonhuman animals matter for feminist scholarship, critique and politics. However, my purpose is not only to examine Sullivan's work but also to develop an alternative strategy of critique.

I suggest that it is important to resist the tendency in recent debates of creating boundaries and gaps rather than inspiring exchange between poststructuralist and natural science-inspired feminist approaches. To provide an alternative to reading strategies which assume new materialism and poststructuralism as separate frameworks with a gap between, I explore what I tentatively call a 'fluid' reading strategy, inspired by new materialisms. From process philosophy, new materialists draw the idea of the world as affective and fluid movements (Kontturi 2014). Here, I do not endorse process ontology or make an ontological argument but rather, I explore a strategy of reading which attunes to feminist theory production and argumentation as movement.

My reading strategy is an attempt at sensitivity to the nuances of these debates, a deliberate attempt not to oppose nonhuman animal studies and new materialisms to poststructuralist feminisms but rather, to explore how, by drawing important points from both perspectives, the queer potential of becoming-with nonhuman animals can be assessed. Crucially, I am neither arguing for poststructuralist approaches against natural science-inspired new materialisms nor for new materialisms against poststructuralist approaches. Being influenced by both makes me move between what seems to be constructed as the different 'poles' of these debates. However, I am convinced of the importance for feminisms of 'staying with the trouble in serious multispecies worlds' (Haraway 2016: 12). That is, I believe discussion about nonhuman animals is indeed a valuable 'critique of our own'. Aligning with the trouble, I strive for a transdisciplinarity within feminism that draws inspiration 'beyond disciplines and beyond existing canons' (Lykke 2004: 96-97), in this case both from natural science-inspired new materialisms and poststructuralist feminisms.

In what follows, I discuss issues related to how and whether feminist theory becomes-with (Haraway 2016: 12) nonhuman animals. ${ }^{1}$ I first discuss poststructuralist understandings of the intertwining of science and politics and their implications for engagement with scientific accounts of nonhuman animals. Secondly, reading the feminist scholar of the history of sex hormones and genetics, Helga Satzinger (2012), I illustrate how a nuanced engagement with sciences which bridges poststructuralist critique and a material feminist account of the materiality of concepts (Barad 2007) enables us to account for how different nonhuman animal bodies have enabled various conceptualisations of sex and physical intimacy. This stresses the importance of accounting for how nonhuman animals are enmeshed in the politics of sex. Thirdly, by reading feminist work inspired by studies of nonhumans, particularly by Myra Hird and Stacy Alaimo, I discuss how to read the relevance of accounts of the diversity of nonhuman animal sex(es) for feminist endeavours.

My reading strategy is influenced by Sara Ahmed's note about reading as a 'labour of love' (Ahmed 2008: 30) and by Clare Hemmings' (2011) work on feminist genealogies and, particularly, their affective investments. I also agree about the importance of being sensitive to affects which emerge from the texts one is analysing (Hemmings 2013) and how these affects orient one's reading (Felski 2015). I have also read with admiration feminist texts where critical or analytic rhetoric is built by writing the author's position as implicated in rather than opposed to the problematics being discussed (e.g. Wiegman 2014). One key feature in writing one as implicated is to avoid 'founding gestures' which establish 'identity in and through differentiation' (Sullivan 2012: 302). I avoid founding gestures but suggest an alternative focus on differentiation: moving with the texts by striving to acknowledge multiple differences as well as multiple resonances in the process of 'becoming-with' other feminist texts. Slightly differing from Felski's (2015) analysis of reading, I suggest that suspicious reading is not merely about a suspicious mood but about a particular kind of movement, or rather, a stopping of movement — and inspiration — between theoretical perspectives and scholarly works. Drawing from both poststructuralist work and natural scienceinspired new materialist feminisms, I attempt an alternative, more fluid assessment of these approaches.

\footnotetext{
${ }^{1}$ This Haraway-inspired becoming-with differs, for example, from the project of Deleuze and Guattari's notion of 'becoming animal', because, in the interpretation of Kari Weil, 'what Deleuze and Guattari see as a liberatory plunge into animal difference, outside the confines of human signification and into a state of animality', has 'little to say about the actual animals we live with' (2012: 16). See also Haraway's own critique of Deleuze and Guattari (2008: 30).
} 


\section{ON SUSPICIOUS READINGS OF NATURAL SCIENCES}

Regarding politics, a crucial disagreement between 'poststructuralist' perspectives — approaches inspired, for example, by Foucault and Butler — and the 'new materialist' approaches concerns whether politics is a mere human endeavour or whether nonhumans should be understood as agentially part of it. Those inspired by new materialist or material feminist arguments view the focus on the nonhuman as not a 'worrying turn away from the more traditional grounds of feminist theory and politics', but instead, 'feminists can come to recognise how nonhumans can be constituted and thought in and through particular worlds in which "we humans" are but one nominated set of players' (Hird and Roberts 2011: 115). I am especially interested in what we make of scientific accounts of nonhuman animals. For some, scientific accounts are interesting, for example, because they can help in formulating how nonhumans are agential and, in this sense, can be seen as participating in 'politics' (e.g. Hird 2009a; Bennett 2010). In some poststructuralist perspectives - which are certainly not the only possible ways to be inspired by poststructuralisms (or Butler or Foucault) - the political is, rather, situated in human practices, and sciences appear in contrast to political endeavours. For example, political and feminist theorist Tuija Pulkkinen defines political thought in contrast to scientific endeavours:

By political thinking I mean seeing the contingency of things; seeing that things could also be differently. In this sense, political thinking can maybe best be contrasted to a universalized "scientific" approach that strives to unambiguously explain how things are in reality. (Pulkkinen 2011: 37, my translation)

A political analysis instead focuses on 'practices that are constitutive of discursive objects' (Oksala 2011: 289). This understanding, inspired by Foucault (for Oksala) or Butler (for Pulkkinen), involves a commitment to an ontology which is not stable and eternal, which can be politicised and which is ultimately a result of political struggles - a point I suggest is extremely important. However, Oksala then defines agency related to these struggles:

Foucault did not discover a previously unknown new agency, called practice. Practices do constitute subjects and objects, but practice is not a prime mover or a hidden engine that creates reality; it is what people do. (Oksala 2011: 289; my emphasis)

Here, change is articulated as a result of politics and what people do. According to such a critical feminist project, if politics is related to natural science, it is a project of outsider critique, showing how natural science research and its results are not neutral or objective. From this perspective, the results of scientific practices are products of human conceptualisation. If something other than human practices exists, it is not assumed to be agential, but as Oksala states, 'this preconceptual materiality can be objectified in different ways in different historical practices' (Oksala 2011: 290). Moreover, at least part of the 'metaphysical background beliefs operative in scientific research (...) can be fairly easily articulated and critically scrutinised' (Oksala 2011: 287). From this perspective, natural science conceptualisations hardly appear interesting, as such or for queerfeminist projects, because this approach implies criticising natural sciences suspiciously and 'from above' rather than allowing an encounter (movement towards) which can inspire queerfeminist analyses and further encourage accounting for the significance of scientific accounts of nonhuman animals for and in feminist theorising and politics.

A similar understanding of relations of science and politics is also implied within Sullivan's argument. In her article, politics is first and foremost situated in the visual: 'visuality is, by definition, an ethicopolitical phenomenon' (2012: 303). This, then, pertains to how we can understand scientific 'facts', and in her reading, this becomes problematic in 'new materialism'. Sullivan's critical strategy in answering the critique posed against poststructuralists is to suggest that new materialists themselves do what they purport poststructuralists do, namely make a distinction between nature and culture: ${ }^{2}$

'The body' as it is (re)presented in the vision Alaimo and Hekman offer is imbued with or animated by something (they perceive as) other-than-cultural - a force which, by implication, must, one can only presume, be 'natural', fundamental, a priori. Moreover, this 'more-than-human' or 'other-than-cultural' force, this nature as agentic, is clearly conceived as separate from, at odds with and prior to 'humans', and the (instrumentalist) technologies with which we aim to apprehend the world. (Sullivan 2012: 301)

These technologies are called by Sullivan the 'somatechnics of perception', which constitute our vision. This pertains to how 'facts' are understood, or rather, questioned. Drawing, for example, from Donna Haraway, Bruno Latour and others, facts are always 'made':

\footnotetext{
${ }^{2}$ In the case of making the distinction between nature and culture, I disagree with both the alleged critique of poststructuralists and Sullivan's reading of the new materialists, but this is not the focus of my present paper (see Irni 2013a, 2013b).
} 
Facts are (...) crafted, they are the vehicle and effect of particular technés, particular learned ways of seeing and knowing, particular orientations to the world, rather than a priori things-in-themselves. (Sullivan 2012: 311, note 9)

This concerns both facts about 'nature' and our readings of other scholarly work. Crucially, from this perspective, scientific studies cannot contribute much in terms of feminist politics - the politics, rather, being 'located' in the questioning of scientific visions. These approaches exemplify one way in which feminists relate to natural sciences, by way of critique in contrast to engagement (Hird 2009b: 330-331, 343). I suggest that here the crucial difference between critique and engagement is not between acknowledging the 'political' inherent in knowledge production (critique) and an uncritical taking-for-granted of scientific perceptions (engagement). Rather, the engaging ('moving-with') approach, in addition to assessing non-innocent ways of knowledge production, instead accounts for more details and acknowledges differences within scientific endeavours. Because the type of above-mentioned poststructuralist arguments mostly bracket out the possibility of the sciences offering anything 'new' or inspiring for feminist politics, they generally also bracket out the question of how nonhuman animals might matter (or materialise) in discussions of whether natural sciences can inspire feminist politics.

\section{ON EMBODIED CONCEPTS}

Below, I draw upon another feminist perspective on science, sex and nonhuman animals as my guide, that of science historian Helga Satzinger's (2012) account of the politics of gender concepts in the history of genetics and hormone research in Germany before the 1940s. ${ }^{3}$ Importantly, Satzinger's article suggests a profound intertwining of matter and meaning in the sense that scientific conceptualisations of sex are 'embodied', in this case by nonhuman animal bodies. Her work provides an example of how to bridge poststructuralist critique (she remains critical of scientific knowledge production in terms of the ways in which accounts of sex and race are produced) and those new materialist approaches which engage in detailed ways with the sciences. As Satzinger notes:

I also want to stress the point that we have no adequate terminology yet to describe and account for the materiality of different bodies while avoiding the gendered assumptions of the biological sciences. Even the biological constituents of the body, like 'cells', 'genes', 'hormones' and 'chromosomes' embody gendered concepts, which I hope to show. (Satzinger 2012: 736, my emphasis)

The idea that concepts are 'embodied' - in combination with understanding that no 'neutral' gender terminology exists - could be seen to tie together important points from both poststructuralist and natural science-informed analyses. For example, philosopher-physicist Karen Barad, one of the 'new materialists' Sullivan criticises, ponders concepts as 'defined by their specific embodiment' (2007: 143). For Barad, the insight by physicist Niels Bohr that 'concepts are not ideational but rather actual physical arrangements is clearly an insistence on the materiality of meaning making' (2007: 147). Such comments are effectively ignored by readings such as Sullivan's, which suggest that Barad and other 'new materialists' assume the above-mentioned nature-culture gap (see e.g. Sullivan's argument cited above, regarding 'agentic nature' being 'separate from, at odds with and prior to "humans" and their '(instrumentalist) technologies'; 2012: 301). When comments such as Barad's are considered, however, the divide between new materialist and poststructuralist accounts seems less wide. Suggesting that the materiality of different bodies embodies concepts, Satzinger argues - alongside other feminist science studies scholars - that a 'material and practical framework is important in explaining why certain concepts were developed and applied' (2012: 750). The idea of embodied concepts allows an activity or recalcitrance of matter — in this case, in the form of what nonhuman animal bodies enable or disable for scientists — called for by new materialists. It also suggests the inextricable intertwining of 'nature' with concepts of sex.

One of Satzinger's examples is the cross-breeding experiments started in 1913 by geneticist Richard Goldschmidt, attempting to reconcile a genetic understanding of inheritance with embryologic development notions. The older embryology saw sex differences as resulting from the development of an originally 'bisexual'

\footnotetext{
${ }^{3}$ Examples of some of the most discussed feminist scholars who have engaged with the sciences include Elizabeth Grosz (2011) and Elizabeth Wilson (2015). Despite this - space not allowing for an extensive exploration with many different scholars - I want to engage with Satzinger's work. This is because of my own personal interest in histories of the so-called sex hormones but also because Satzinger's empirically rigorous and politically interesting work is not as well known in the feminist Anglo-American mainstream and, as such, deserves to be discussed more. I am also tempted to foreground scholarly work which engages with both sex and race in relation to science and which does not take a stance against poststructuralist feminisms or new materialisms. With this choice of a discussant, I also aim to show that scholarly work which could be read as 'critique' can also be utilised with 'new materialist' work without the need to consolidate the existing boundaries between poststructuralisms and new materialisms.
} 
embryo; according to embryological understanding at the time, every organism had potential to develop in more than one direction in terms of sex. However, the then-dominant chromosomal theory — based on researching animals such as the fruit fly Drosophila - postulated a strict binary difference in sex determination; the organism would develop either into a female or a male.

Accounting for the material conditions of the development of early genetics, Satzinger suggests that in addition to the importance of the microscope and research techniques involving staining, a precondition for developing the chromosomal theory of heredity was 'a new interpretation of fertilisation as the fusion of two morphologically and functionally different germ cells' (Satzinger 2012: 742). Zoologist Theodor Boveri and his wife Marcella Boveri, who also contributed, researched sea urchins and a parasitic worm called Ascaris megalocephala, because both species had male and female forms and therefore, according to the zoologists, could model human heredity. However, because spermatozoa only contributed chromosomes but egg cells also contributed cytoplasm, in order to see their inputs as equal, a particular interpretation of the cytoplasm's function was required, foreclosing the idea that the cytoplasm could also contribute to inheritance. As Satzinger suggests, in Boveri's work, the cytoplasm was considered important 'but only during the embryonic development of the organism'. Satzinger adds:

Here was the realm of female influence, which could be framed in the classic notion of nutrition, care and guidance. (...) For the following decades, this hierarchical gendered order of the cell and hereditary processes created a blind spot for genetics, which focused on the genes in the chromosomes only. Processes of cytoplasmatic organisation of the 'hereditary substance' have since slowly come back into focus under the name of epigenetics. (Satzinger 2012: 744)

While Boveri, whose sea urchins enabled accounting for the importance of cytoplasm, at least acknowledged its importance in an organism's development and its cooperation with chromosomes, further developments pushed the cytoplasm virtually aside. Importantly, the binary account of sex related to heredity strengthened by these developments was not only a question of scientists' binary assumptions but of what the bodies of the model organisms enabled the scientists to conceptualise. With fruit flies, the 'investigation into heredity was reduced to crossbreeding experiments in the search for genes on chromosomes' (Satzinger 2012: 745). Influential in this work was Thomas Hunt Morgan's research, which used the fruit fly Drosophila melanogaster as a model organism. As Satzinger notes, utilising this fruit fly was well suited for the 'establishment of a theory of the gene as sites on the chromosome', but it was 'not as well-suited to investigating the interaction of chromosomes and cytoplasm' (Satzinger 2012: 745). When Drosophila research became popular, the dual, hierarchical gender assumptions in genetics were strengthened rather than questioned. In this sense, scientific gender conceptualisations can be interpreted as 'embodied' — by, among other things, the nonhuman bodies utilised in the experiments.

Goldschmidt, in turn, studied different populations of the gypsy moth Lymantria dispar. These experiments did not support the idea of a strictly binary sex:

Certain combinations of different populations resulted in offspring which no longer showed clear signs of being male or female, such as wing pigmentation or size and morphology of the antennae. Goldschmidt termed these specimen 'intersexes'. He claimed that he could produce all stages of intersexes between male and female by choosing the appropriate populations for his experiments. (Satzinger 2012: 746)

Based on this, Goldschmidt argued that 'every individual organism and even each of its cells had the potential to develop in the male or female direction, with all intermediate stages possible' and that 'masculinity and femininity were not two exclusive binary possibilities, but rather admixtures' (Satzinger 2012: 746). He further suggested that there was no pure masculinity or femininity, but rather, that both were present in each individual, but one or the other may prevail. He could then argue for the decriminalisation of homosexuality 'as one of many natural ways of being' (Satzinger 2012: 746). He also participated in discussions about what was then called 'hermaphroditism', arguing that such individuals should not be assigned to female or male categories, because they did not fit into them (Satzinger 2012: 746). This story suggests that it was not only political ambitions or the human somatechnics of perception that were important, but also the ways in which different scientists conceptualised sex as 'embodied' - by basing their arguments on nonhuman animal bodies. In this sense, research based on nonhuman animals has enabled seeing a multiplicity of sexes as well as what Sullivan (2012: 308) calls seeing 'physical intimacy as radically diverse'. This point does not 'counter' Sullivan's argument but rather, bridges natural science-inspired arguments and poststructuralist arguments, Sullivan's included.

However, Goldschmidt's völkisch and right-wing contemporaries used his research completely differently. Fritz Lenz was a racial hygienist and became a leading human geneticist during the Nazi era. Lenz also studied Lymantria dispar but used both his own and Goldschmidt's results to justify racial hygienic thinking rather than to argue for acceptance of human variety. Satzinger explains: 
For Lenz and his völkish colleagues, the Nordics or Aryans were the most highly developed race. They were characterised by the most pronounced physical and mental difference between men and women, which was marked politically by their difference in their legal status. Lenz saw the blurring of a clear binary human gender order, as it unfolded in the years of the Weimar Republic, as a dangerous sign of racial degeneration. Using the results of Goldschmidt's cross-breeding experiments, Lenz claimed that miscegenation ('Rassenmischung' or even 'Rassenschande') was the genetic cause for this process. (2012: 747)

At this point, miscegenation was mainly seen concerning marriages between so-called Aryans and Jews; the idea that marriages between Jews and 'Germans' (as if Jews could not be Germans) produced degeneration 'by effeminising men and masculinising women' had long circulated. Marriage bans were instituted by the Nuremberg laws in 1935. In 1920s genetics, interpretations based on cross-breeding experiments with gypsy moths strengthened these ideas, which were also used in arguing against women's rights:

According to Lenz and his allies, the highly visible New Woman of the Weimar republic, female suffrage and the efforts to invent new gender orders beyond the heterosexual matrix of strict binaries could be understood as a genetic process of degeneration. (Satzinger 2012: 747)

Even if Satzinger also mentions a range of more empowering arguments based on the sciences during her 1900-1940 study period, the different, contradictory uses of the sciences explain why she argues that feminists should refrain from relying on the sciences when doing feminist politics. In this sense, Satzinger's own analysis despite fine engagement with the nuances of scientific endeavours - consolidates a divide between feminism (assumed to consist of non-scientists?) and science. However, the value of this paper for the task of exploring the queer potential of becoming-with nonhuman animals is in her sensitive attending to the embodiment of nonhuman animals in theories of sex. She shows in detail the relevance of not only the gendered and racialised assumptions guiding scientific interpretations but also the significance and participation of different and particular nonhuman animal bodies - how they have embodied and enabled different conceptualisations and politics of sex and race. In this sense, her study exemplifies how nonhuman animal bodies are hard to extract from feminist concern about and critique of the politics of sex. Therefore, I see much value in feminist accounts which attend to how, for example, 'bonobos, bowhead whales, bighorn sheep, buff-breasted sandpipers, aphids' (Sullivan 2012: 308) and other critters embody concepts related to sex and the sexuality also of humans and, at times, how they participate in broadening both scientific and political perspectives on sex.

\section{ON READING SCIENCE-ENTHUSIASTIC FEMINISTS}

In my reading, Sullivan's suspicion towards studies of nonhuman animals stems from her way of responding to two different but intertwined questions. One is the question about relations between the natural sciences and what Hemmings (2011) calls 'interdisciplinary humanities', and the natural science-inspired feminist arguments where feminists are encouraged to take into account the activity of 'matter' (e.g. Barad 2003; Birke 2003; Hird 2009a, 2009b; Kirby 2011; Wilson 2010). The other question concerns accounting for varieties of what is called 'sexual behaviour' in nonhuman animals. Sullivan is critical of arguments she reads as suggesting that feminists make 'scientific studies' primary, in other words, the assumption that scientific studies both enrich feminism and produce knowledge feminism cannot do without:

I am both sceptical about, and uncomfortable with, the idea that we must turn to the voice of authority (in the guise of science or male philosophers) in order to see clearly, and so for strategic ethico-political reasons, I will resist such a move. (Sullivan 2012: 308)

I read this as connected to her reading that sex and sexuality are primarily understood in the sciences in relation to species-being. Let me emphasise these parts of her argument:

Why (...) do we need to turn to 'scientific' studies of bonobos, bowhead whales, bighorn sheep, buffbreasted sandpipers, aphids, to see physical intimacy as radically diverse? Why do we need to look to bacteria (or, more correctly, to contemporary scientific perceptions of bacteria as a form of species-being) in order to envisage our 'selves' as other than singular bounded beings whose identity is innate and unchanging? (Sullivan 2012: 308, emphasis added)

In terms of species-being — what Sullivan sees these studies as being about — I interpret her worry as concerning the reduction of sex and sexuality to a question of species-specific reproductive practices, thus neglecting cultural aspects involved in sex and the sexual practices of humans, as well as ways in which these 
nonhuman practices are interpreted as 'sexual' (for a similar argument, see Kulick 1997). My interpretation of Sullivan relies on the following:

It is a small, and seemingly logical step then [after positing matter and nonhuman animal behaviours and morphologies as 'more-than- or other-than cultural'] to imagine 'sex' in terms of agentic physical/material processes - the ejaculation of semen, the contraction of nerves, increased blood flow, muscular spasms, the production and release of pheromone-soaked scent and so on, which combine in ways that make sex as an act which occurs (usually, but not always) between members of a particular species, visibly self-evident. (Sullivan 2012: 309-310)

Sullivan adds that 'this particular vision constitutes life in terms of species-being' rather than being a description of that which exists as such (2012: 310). I agree here, in the sense that I also find it problematic if readings of sciences which promote binary understandings of sex and sexuality, such as very particular evolutionary narratives, are assumed as a truth-base for feminism in the understanding of sex and sexuality (for an example of such an argument, see Rotkirch 2003). I find this problematic, particularly if it is assumed as a one-way interdisciplinary relation, where natural sciences are simply assumed to provide 'hard facts' about nature, without simultaneously claiming that natural scientists themselves need to take seriously ways in which what Sullivan calls somatechnics of perception affect their work (see also Ahmed 2008; Irni 2013a; Kulick 1997: 231; Roy 2008). However, note that feminist work, and Myra Hird's particularly (Hird has focused on bacteria, and Sullivan seems to refer to her in the comment above on bacteria), also problematises the centrality of binary sex in evolutionary narratives, including the problematisation of what the very notions of sex or reproduction indicate, and Hird's work focuses on evolutionary narratives based on species mergence rather than differentiation (Hird 2009a: 83, 91-115; Hird 2012). This means that for feminist scholars inspired by biological sciences, understanding nonhuman bodies far exceeds any simplistic narratives which lead to imagining sex as 'the ejaculation of semen, the contraction of nerves, increased blood flow, muscular spasms, the production and release of pheromone-soaked scent and so on', as expressed by Sullivan.

Indeed, another background intertwined with Sullivan's arguments derives from discussions raised by the biological sciences and from studies which have shown varieties in various species in terms of what these studies call 'sexual behaviour'. Those enthusiastic about these developments argue, for example:

Notwithstanding the sheer delight of dwelling within a queer bestiary that supplants the dusty, heteronormative Book of Nature, the recognition of the sexual diversity of animals has several significant benefits. Most obviously, scientific accounts of queer animals insist that heteronormativity has damaged and diminished scientific knowledge in biology, anthropology, and other fields. (Alaimo 2010: 54)

Sullivan makes the focus on nonhuman animal research problematic by analysing Myra Hird's (2008) article 'Animal Trans' as well as her research on bacteria. Sullivan is not convinced that such studies help us 'see physical intimacy as radically diverse' (2012: 308; see the longer quotation in the introduction). Her concerns seem to align with those of other critics, who argue, for example, that gay rights advocates might be 'better off relying on other discourses through which civil rights are claimed', because '(s)uch evidence remains inconclusive, uneasily generalizable across species, subject to wildly divergent interpretations, and likely to fail the endeavor of understanding animal behavior on its own terms' (Chris 2006: 165; cited in Alaimo 2010: 58). Sullivan argues that the problem lies in the following, referring to her reading of a particular white optics as exemplified by a Scottish 'Lady of Quality', Janet Schaw, who belonged to the eighteenth century colonial elite and who tells a story in her journal about misperceiving black children as monkeys:

In each case, organisms perceived as belonging to a particular species (in terms of 'genus' and 'sexuality') are looked at, their being is interpreted (and thus constituted) in and through a perceptual schema that is particular to those who are doing the looking; a universalizing (anthropomorphic and/or colonizing) heteronormative optics that reduces alterity to its own terms, in much the same way as the encounter between Schaw and the anonymous 'non-human' 'negro children' does. (2012: 305)

I agree that reducing alterity to one's own terms remains problematic, an example being the labelling of particular animals as 'queer'. However, this is also acknowledged by Myra Hird, who critically analyses her own previous text:

The problem with my [earlier] argument, it seems to me now, is that I read nonhuman living organisms through the lens of queer, rather than critically reflecting upon how we socioculturally constitute queer and how we might read queer through a nonhuman lens. (...) we need to resist the temptation to name 
certain species as queer. (...) It is much more interesting to consider how we might understand trans in humans from, say, a bacterial perspective. (Hird 2008: 242-243, cited in Sullivan 2012: 306)

Yet Sullivan is not convinced by her argument and suggests that:

there nevertheless remains the problematic conflation in her schema, of seeing otherwise, of "reading through a nonhuman lens", with a move beyond (the limits of) "culture-centrism" which she associates with a particular kind of poststructuralist feminist enterprise; one that overlooks, fails to recognize, or misperceives that which is seemingly beyond or other than, "culture" (Sullivan 2012: 306).

Here I claim that Sullivan's reading, however, amounts to a hermeneutics of suspicion, as described by Rita Felski (2015: 1), where 'the task of the social critic is now to expose hidden truths and draw out unflattering and counterintuitive meanings that others fail to see.' Paradoxically, while Sullivan criticises Hird for criticising poststructuralism (for failing to see), Sullivan's own reading posits a similar argument; even if Hird has transformed her own thinking, she (still, according to Sullivan) criticises poststructuralism and fails to see a problem in her own enthusiasm with bacteria and the inspiration which various biological arguments can give. However, Hird's example cited by Sullivan to back up her argument contains no explicit criticism of feminists or poststructuralists in general. In other words, I see no necessary connection between critique of poststructuralism and engagement with biological sciences, and I suggest that Sullivan's critique here constructs an unnecessary gap between poststructuralism and such engagement in Hird's text.

I also find the analogy Sullivan constructs between racialisation and Hird's and other 'new materialist' arguments not to be so useful:

These founding gestures (which are central to Hird's thesis, and typical of new materialism more generally) seem to me to share much with the somatechnics of perception at work on that hot December day in 1774 when Janet Schaw encountered the anonymous 'nonhuman' 'negro children' (...)' (Sullivan 2012: 307)

As Sullivan does not specifically show any racialisation in Hird's work or other new materialists she discusses, I suggest that this move, rather than being an apt critique of the work she discusses, risks amounting to framing oneself as engaged in 'radical intellectual and/or political work' (Felski 2015: 2). Sullivan, while drawing on 'white optics' as a key notion of her critical endeavour (which is fine), ignores the postcolonial critique by which some of those whom she labels new materialists, for example, Karen Barad, have been inspired (see Irni 2013a: 357-358). The analogy to racialisation therefore appears first and foremost as serving to strengthen Sullivan's argument and her position as critic, rather than doing apt critical work in terms of her reading of the 'new materialists' she cites. (Note that I am not arguing that new materialism per se is free from white optics; see also Irni 2013a.)

That said, I read Sullivan as suggesting that the problem is not the analysis of nonhuman animals per se (she refers appreciatively several times to Haraway, including Haraway's (2008) When Species Meet). Rather, the problem is whether such readings assume that the behaviour of nonhuman animals can be approached without any 'somatechnics of perception' and be used as a critique against poststructuralist feminists and their 'inability' to see 'beyond' culture. In my reading, Hird's (2008) point is to approach critically neither feminists in general nor poststructuralist feminists particularly. Instead, she specifically criticises a few trans-unfriendly feminist arguments that posit cis-women as more authentic or natural than other women. According to Hird, these arguments are based on human-centred understandings of technology (an assumption that human transformations of sex characteristics are not natural because they involve technology) as well as a binary ontology of sex assumed as natural. As Hird shows, these arguments do not hold if 'nature' is read in terms of various nonhuman critters and their ability to use technology, and if the many-faceted variations of sex and sex transformations are assessed.

I agree with Sullivan that it is problematic if arguments derived from the natural sciences are taken as primary as such, compared to cultural studies and humanities. However, I do not read Hird's project in terms of queer and trans politics involving 'the idea that we must turn to the voice of authority (in the guise of science or male philosophers) in order to see clearly' (Sullivan 2012: 308). Neither does Hird's project simply consist of making an analogy between trans persons and the sex transformations of nonhumans (such projects are also criticised by Kulick 1997) — an analogy which might involve a problematic reading of nonhuman animal behaviour in human terms. The point of Hird's critique, in my reading, is not that biological sciences should exert an authority which decides whether feminisms should be inclusive or whether particular types of passions, behaviours or identities are acceptable, - but rather, it is her problematisation of assumptions related to nature, the natural and authenticity. I read this, rather than as reductionist endeavour, as transdisciplinary work contributing to assessing how feminist theory becomes-with nonhumans. 


\section{ON THE AWE-SOME SEX(ES) OF NONHUMAN ANIMALS}

The problematics of interpreting nonhuman animal behaviour and making analogies to human behaviour (e.g. in Kulick 1997) and of forgetting the somatechnics of perception (Sullivan 2012) raise yet another kind of challenge. It is appropriate to ask whether some of these studies, such as Sullivan's, that criticize feminist scholarship inspired by nonhuman animal studies draw their argument from the human-centred assumption that nonhuman animals do not have culture. Stacy Alaimo notes:

In terms of environmental ethics and politics, it is crucial to acknowledge animals as cultural beings, enmeshed in social organizations, acting, interacting, and communicating. An understanding of animal cultures critiques the ideology of nature as resource, blank slate for cultural inscription, or brute, mechanistic force. (2010: 60)

Even if Sullivan argues that it is problematic to perceive nonhuman animals as outside of culture, her solution is not to recognise culture in nonhuman animals but, rather, to question the relevance of scientific accounts of nonhuman animal sex for feminist critique. She assumes that nonhuman animal behaviour is in scientific accounts (necessarily?) misperceived by researchers, and that animal alterity is reduced to the researchers' own terms (Sullivan 2012: 305). Here, I suggest, is another instance of the hermeneutics of suspicion. The point of feminist discussions as I read them is not to make direct, simple analogies between nonhuman animal and human behaviour but is to approach nonhuman animals from the perspective of the complexity and diversity of the animals' own behaviour. In addition, discussions such as those of Alaimo (2010) and Hird (2009a, 2012) criticise heteronormative assumptions and the linking of sex and reproduction in the biological sciences as well as recognising that humans are not so unique in their capacities, after all. Within research concerning queer and trans perspectives with respect to nonhuman animals, there may be simplifications, but this does not mean these perspectives should be wholly neglected and their value for feminisms denied. Alaimo (2010: 66), for example, criticises some accounts of nonhuman animals for offering interpretations which clearly anthropomorphise nonhuman animal behaviour, for example in discussing domestic violence or divorce in nonhuman animals. Instead of concluding from these challenges that studying nonhuman animal behaviour is useless or is necessarily problematic, Alaimo calls for accounts which give value to 'scientific accounts of sexual diversity in nonhuman animals, in the sense that these accounts are accounting for something — something more than a (human) social construction' (2010: 67).

I do not interpret Alaimo to be arguing that animal behaviour can be accessed 'as such' without the 'somatechnics of perception,' to use Sullivan's terminology. Rather, I interpret the quotation from Alaimo given above as acknowledging the diversity of nonhuman animal behaviour. Sullivan herself criticises the introductory chapter to the book Material Feminisms, by Alaimo and Susan Hekman, giving the impression that these scholars fiercely oppose poststructuralism (Sullivan 2012: 300-301). Yet in that introduction, we find a comment (concerning the chosen authors in the book), which guides my reading of Alaimo also with respect to her nonhuman animal accounts:

We have brought together thinkers who are attempting to move beyond discursive construction and grapple with materiality. A central element of that attempt, however, is to build on rather than abandon the lessons learned in the linguistic turn. (Alaimo and Hekman 2008: 6)

I read such an approach, for example in Alaimo's argument, that a feasible account of 'sexual diversity in nonhuman animals' simultaneously 'encourages an epistemological-ethical stance that recognizes the inadequacy of human knowledge systems to ever fully account for the natural world' (2010: 67).

In a sense, Sara Ahmed's (2000) notion of strange encounters may enable an understanding of these challenges. Ahmed problematises cultural understandings of the 'strange', noting that some persons are culturally recognised as strangers rather than inherently being unfamiliar. In this process, both strange and familiar become effects of a particular somatechnics:

Perception, then, is both the vehicle and effect of a particular situated somatechnics, an orientation to the world in which the I/eye is always-already co-implicated, co-indebted, co-responsible. (Sullivan 2012: 302)

For Sullivan (and other poststructuralists and most new materialists, I would claim), this means that nonhuman animals cannot be approached as such. While I agree with the importance of accounting for the somatechnics of perception, at this point, Sullivan's reading can be said to create an impasse; it appears as though the reading of queer potential in scholarship on nonhuman animals can only involve a problematic, unreflected conflation of human concepts of nonhuman animal life. (However, as pointed out above, sometimes it may be the other way around, as sometimes it is the matter of particular nonhuman animal bodies which enables human concepts.) 
Attempting to read those inspired by queer accounts of nonhuman animals — such as Alaimo — in a more benign way, I suggest that studies which queer nonhuman animals themselves involve struggling with learning to see nonhuman animal sex otherwise, to broaden all-too-familiar patterns of seeing.

I propose that this learning to see otherwise has its own value, which is not dependent on how contested these readings of nonhuman behaviour might be within the sciences in question. As I interpret Alaimo, the value of research on varieties of animal sexual behaviour is mainly in the affective opening up of imagination to new possibilities in thinking about sex and gender (Alaimo 2010: 67-68). Crucially, I interpret this to suggest that this opening up relates to the fact-value assumed of these studies (=that they are science) and that, for example, science fiction would not do the same affective job. However, rather than reading Alaimo as implying an argument against poststructuralism or for believing uncritically in 'facts', I read this opening up as a sort of 'becoming-queer-with nonhuman animals'. By this I do not mean that the person who reads stories about queer nonhuman animals starts identifying as non-heterosexual; rather, I mean to point out the affectively moving reading process for some readers. For example, it seems that readers such as Alaimo experience this reading as opening up new worlds, helping one to see anew relations among nonhuman animals and to rethink one's own relationality to 'nature' and nonhuman animals. In this sense, I agree with Sullivan that 'perception is always-already "of-the-world", always already a co-constitutive "seeing-with" that shapes the seer and the seen, the knower and the known, such that they are always intertwined (although never reducible to one another)' (2012: 303). Learning to see anew might then constitute a 'seeing-with' nonhuman animals which transforms the seer as well as perceptions about these critters.

Alaimo cites several readings which describe, for example, the exuberance of nature which overwhelms, the inventiveness which shatters human categorisations, the experienced wonder and a profound sense of awe (2010: 67-68). Alaimo herself states, regarding her reading processes:

I must admit that I was rather astonished by Hird's, Roughgarden's, and Bagemihl's accounts of the enormous variety of sexual diversity throughout the nonhuman world. Who knew? (2010: 56).

She further narrates this experience as a 'sense of astonishment' (2010: 56). One issue bracketed by Sullivan's sceptical argumentation is the affective potential which queering nonhuman animals seems to enable. Alaimo writes:

Despite the scientific aim to make sense of the world, to categorize, to map, to find causal relations, many who write about sexual diversity in nonhuman animals are struck with the sense that the remarkable variance regarding sex, gender, reproduction, and childrearing among animals defies our modes of categorization, even explodes our sense of being able to make sense of it all. These epiphanic moments of wonder ignite an epistemological-ethical sense in which, suddenly, the world is not only more queer than one could have imagined, but more surprisingly itself, meaning that it confounds our categories and systems of understanding. (2010: 67)

Such affective (reading) encounters with nonhuman animals, affective 'becoming-queer-with', are not primarily oriented against poststructuralism; nor is their value only in the adequacy of the facts. Rather, such encounters can open up potential — as Alaimo (2010: 68) puts it, the potential to 'foster queer-green ethics, politics, practices, and places. ${ }^{4}$

\section{ON MOVEMENTS AND FLOWS IN FEMINIST CRITIQUE}

I chose Sullivan's (2012) text for this scrutiny and thinking-with because it inspired me in interconnected ways. First, as I share several of her arguments as well as some from the new materialists she criticises, it is inspiring to practice an alternative reading strategy which does not choose a stand on 'either side' of these debates. Secondly, her critique, as well as more enthusiastic work on nonhuman animals, provoked me into thinking through feminist readings also as practices of becoming-with nonhuman animals.

I find important Felski's and Berlant's observations of our affective immersion in our critique. However, I also wish to introduce critique as movement. I have been inspired by Felski's account of the tradition of the hermeneutics of suspicion in critical studies more broadly, and I have made use of it in my reading of Sullivan. Both Sullivan and I affectively defend feminists whom we feel are read in unfair ways, but our mood and mode of reading differs related to those feminists inspired by scientific studies on nonhuman animals. While Sullivan remains sceptical, I advocate a more fluid reading and open mood, which also enables movement and inspiration

\footnotetext{
${ }^{4}$ For example, such potential includes more adequate political responses to toxic environments and chemicals which do not fuel the trans- and queerphobic tendencies in some environmentalist activism (for critiques of these tendencies, see Di Chiro 2010; Honkela and Irni 2014).
} 
between new materialisms and poststructuralisms. This fluid reading attempts to account for nuances in the discussed work and avoids merely picking out sentences which enable a certain kind of critique (as I suggest Sullivan does, for example, in her readings of Alaimo and of Barad).

Rather than abandoning critique for 'postcritical' (Felski 2015) reading habits, however, I have here explored a reading strategy - or critique, if you will — which allows moving between and both with and against theories one reads, rather than necessarily sentencing theorists one criticises fully to the 'against' category (as Sullivan seems to do with new materialists). I suggest that such a reading habit, which Felski calls 'suspicious', practised by Sullivan, is not only about suspicious mood. I wish to pay attention to the movement at hand. As Felski argues, a suspicious mode of reading is 'parasitic' and 'could not survive without the very object it condemns'; but simultaneously, suspicious 'critique opens up a gap between itself and its object' (2015: 126). In my interpretation, what is crucial is the building up of (what I see as an unnecessary) gap between the discussed approaches and theorists, the stopping of the inspirational movement and flow between various new materialist and poststructuralist approaches.

It is certainly clear by now - because I have also voiced my disagreements with Sullivan - that the fluid reading I advocate does not propose merely to agree or to empathise with the text. While I prefer reading approaches which seek contact and inspiration — movement with — rather than writing only against other feminisms, a 'fluid' critique is not always in agreement. Rather, it attempts to voice disagreements in a more nuanced way; it strives for sensitivity to differences — for example, as nuances and details in argumentation (see Irni 2013b) — and, as already noted, sensitivity to the affectivity involved in reading. As Susan Strickland (1994) has noted, encountering differences and disagreements sometimes includes becoming painfully aware of one's situatedness and perception. However, this process, at least for me, also entails a possibility for affective becoming-with feminist arguments.

As Felski says, finding alternatives to the suspicious reading habit 'would allow us to be surprised by what our colleagues have to say; it would encourage us to pose different questions as well as discover unexpected answers' (2015: 150). This includes colleagues across the humanities and the social and natural sciences and the various ways in which nonhuman animals can be part of feminist theoretical intimacies — animating feminist theory, as I argue, for example, one finds in Hird and Alaimo. Indeed, in several ways, nonhuman animals are important for feminist scholarship and politics. Even if scientific accounts of nonhuman animals cannot always be taken as 'facts' which should or can guide feminist politics, it is important to acknowledge which nonhuman animal bodies are embodied in which facts and with what consequences (both to the animals themselves and to our scientific conceptualisations of sex and race). In this paper, I have considered it affectively important to learn to see the diversity of sex 'in nature'. Like Alaimo (2010), I wish to see more queer-green collaborations, which such readings may effect. It is important to avoid interpreting nonhuman alterity merely in our own terms, as Sullivan (2012: 305) stresses, and, as Alaimo (2010: 60) suggests, to learn to recognise nonhuman animals as themselves 'cultural beings' and as otherthan-resource, for both our theorisation and our practices.

\section{ACKNOWLEDGEMENTS}

I thank Turku Institute for Advanced Studies (TIAS) for funding the writing of this manuscript, as well as the editors of this special issue for constructive and helpful comments.

\section{REFERENCES}

Ahmed, S. (2000). Strange Encounters. Embodied Others in Post-Coloniality. London: Routledge.

Ahmed, S. (2008). Open Forum, Imaginary Prohibitions: Some Preliminary Remarks on the Founding Gestures of the 'New Materialism.' European Journal of Women's Studies, 15(1), pp. 23-39. https://doi.org/10.1177/1350506807084854

Alaimo, S. (2010). Eluding capture: The Science, culture, and pleasure of "queer" animals. In: C. MortimerSandilands and B. Erickson, eds., Queer Ecologies. Sex, Nature, Politics, Desire (pp. 51-72). Bloomington: Indiana University Press.

Alaimo, S. and Hekman, S. (2008). Introduction: Emerging Models of Materiality in Feminist Theory. In: S. Alaimo and S. Hekman, eds., Material Feminisms (pp. 1-19). Bloomington \& Indianapolis: Indiana University Press.

Barad, K. (2003). Posthumanist Performativity: Toward an Understanding of How Matter Comes to Matter. Signs: Journal of Women in Culture and Society, 28(3), pp. 801-831.

Barad, K. (2007). Meeting the Universe Halfway: Quantum Physics and the Entanglement of Matter and Meaning. Durham, NC: Duke University Press.

Bennett, J. (2010). Vibrant Matter. A political ecology of things. Durham and London: Duke University Press. 
Birke, L. (2003). Shaping Biology: Feminism and the Idea of 'the Biological.' In: S.J. Williams, L. Birke and G.A. Bendelow, eds., Debating Biology: Sociological Reflections on Health, Medicine and Society (pp. 39-52). London: Routledge.

Birke, L., Bryld, M. and Lykke, N. (2004). Animal Performances. An Exploration of Intersections between Feminist Science Studies and Studies of Human/Animal Relationships'. Feminist Theory, 5(2), pp. 167-183. https://doi.org/10.1177/1464700104045406

Chris, C. (2006). Watching Wildlife. Minneapolis: University of Minnesota Press.

Di Chiro, G. (2010). Polluted Politics? Confronting Toxic Discourse, Sex Panic, and Eco-Normativity. In: C. Mortimer-Sandilands and B. Erickson, eds., Queer Ecologies. Sex, Nature, Politics, Desire (pp. 199-230). Bloomington and Indianapolis: Duke University Press.

Felski, R. (2015). The Limits of Critique. Chicago and London: The University of Chicago Press.

Grosz, E. (2011). Becoming Undone. Darwinian Reflections on Life, Politics, and Art. Durham and London: Duke University Press.

Haraway, D. (2008). When Species Meet. Minneapolis: University of Minnesota Press.

Haraway, D. (2016). Staying with the Trouble. Making Kin in the Chthulucene. Durham and London: Duke University Press.

Hemmings, C. (2011). Why Stories Matter. The Political Grammar of Feminist Theory. Durham, NC and London: Duke University Press.

Hemmings, C. (2013). Considering Emma. European Journal of Women's Studies, 20(4), pp. 334-346. https://doi.org/10.1177/1350506813502022

Hird, M. (2008). Animal Trans. In: N. Giffney and M. Hird, eds., Queering the Non/Human (pp. 227-247). Farnham: Ashgate.

Hird, M. (2009a). The Origins of Sociable Life: Evolution after Science Studies. Basingstoke: Palgrave MacMillan.

Hird, M. (2009b). Feminist engagements with matter. Feminist Studies, 35(2), pp. 329-346.

Hird, M. (2012). Digesting difference: metabolism and the question of sexual difference. Configurations: a Journal of Literature, Science, and Technology, 20(3), pp. 213-237, 342. https://doi.org/10.1353/con.2012.0019

Hird, M. and Roberts, C. (2011). Feminism Theorises the Nonhuman. Feminist Theory, 12(2), pp. 109-117. https://doi.org/10.1177/1464700111404365

Honkela, N. and Irni, S. (2014). Hormonaalisesti vaikuttavat ympäristökemikaalit ja kestävyyden etiikka. In: S. Irni, M. Meskus and V. Oikkonen, eds., Muokattu elämä: teknotiede, sukupuoli ja materiaalisuus (pp. 380-411). Tampere: Vastapaino.

Irni, S. (2013a). The Politics of Materiality. Affective Encounters in a Transdisciplinary Debate. European Journal of Women's Studies, 20(4), pp. 347-360. https:// doi.org/10.1177/1350506812472669

Irni, S. (2013b). Kun jälkistrukturalismi kohtaa luonnontieteistä inspiroituneen uusmaterialismin: Herkän luennan harjoitus. Naistutkimus - Kvinnoforskning, 26(4), pp. 5-16.

Kirby, V. (2011). Quantum Anthropologies: Life at Large. Durham, NC: Duke University Press.

Kontturi, K. (2014). Taide, tekniikka ja radikaali prosessiajattelu. In: S. Irni, M. Meskus and V. Oikkonen, eds., Muokattu elämä: teknotiede, sukupuoli ja materiaalisuus (pp. 412-435). Tampere: Vastapaino.

Kulick, J. (1997). Är måsar lesbiska? om biologins relevans för mänskligt beteende. Res publica, 35/36(1/2), pp. 221-232.

Lykke, N. (2004). Women's/gender/feminist studies: A post-disciplinary discipline? In: R. Braidotti, E. Just and R. Mensink, eds., The Making of European Women's Studies (pp. 91-102). Utrecht: Utrecht University/Athena.

Oksala, J. (2011). How is Feminist Metaphysics Possible? Feminist Theory, 12(3), pp. 281296. https://doi.org/10.1177/1464700111417667

Pulkkinen, T. (2011). J.V. Snellman poliittisena ajattelijana - siveellisyys. In: T. Pulkkinen and A. Sorainen, eds., Siveellisyydestä seksuaalisunteen: poliittisen käsitteen bistoria (pp. 36-55). Helsinki: Suomalaisen Kirjallisuuden Seura.

Rotkirch, A. (2003). Naturligtvis? Moderskap, essentialism och evolutionsteori. Naistutkimus - Kvinnoforskning, 16(3), pp. 33-47.

Roy, D. (2008). Asking Different Questions. Feminist Practices for the Natural Sciences. Hypatia, 23(4), pp. 134157.

Satzinger, H. (2012). The Politics of Gender Concepts in Genetics and Hormone Research in Germany, 19001940. Gender \& History, 24(3), pp. 735-754.

Strickland, S. (1994) Feminism, Postmodernism and Difference. In: K. Lennon and M. Whitford, eds., Knowing the Difference. Feminist Perspectives in Epistemology (pp. 265-274). London: Routledge.

Sullivan, N. (2012). The Somatechnics of Perception and the Matter of the Non/human: A Critical Response to New Materialism. European Journal of Women's Studies, 19(3), pp. 299-313. https://doi.org/10.1177/1350506812443477

Weil, K. (2012). Thinking Animals. Why Animal Studies Now? New York: Columbia University Press. 
Wiegman, R. (2014) The Times We're in: Queer Feminist Criticism and the Reparative 'Turn'. Feminist Theory, 15(1), pp. 4-25. https://doi.org/10.1177/1464700113513081a

Wilson, E. (2010). Underbelly. Differences: A Journal of Feminist Cultural Studies, 21(1), pp. 194-208. https://doi.org/10.1215/10407391-2009-027

Wilson, E. (2015). Gut Feminism. Durham and London: Duke University Press.

Citation: Irni, S. (2017). Fluid Reading Practice: On the Queer Potential of Studying Nonhuman Animals. Feminist

Encounters: A Journal of Critical Studies in Culture and Politics, 1(1), 05. https://doi.org/10.20897/femenc.201705

Copyright (C) 2017 by Author/s and Licensed by Lectito BV, Netherlands. This is an open access article distributed under the Creative Commons Attribution License which permits unrestricted use, distribution, and reproduction in any medium, provided the original work is properly cited. 
http://www.lectitopublishing.nl

https://www.facebook.com/LectitoJournals/

https://twitter.com/lectitojournals

$\mathcal{S}_{+}$https://plus.google.com/110901545130385419486

in https://www.linkedin.com/in/lectito-journals9a675010b/ 


\title{
A Pace of Our Own? Becoming Through Speeds and Slows - Investigating Living Through Temporal Ontologies of The University
}

\author{
Malou Juelskjær ${ }^{1 *}$, Monika Rogowska-Stangret ${ }^{2}$
}

Published: October 30, 2017

\begin{abstract}
This article is concerned with new feminist materialism's transformatory ethical potential with regards to the (fast) neoliberal university. It is also shaped and inspired by Karen Barad's question: 'How can I be responsible for that which I love?' (Barad 2016). The text thus investigates possibilities of thinking through new materialist theorising and concepts for examining conditions of the $\mathrm{im} /$ possibilities of living live-able academic lives in current political climates. As a response to those conditions a cry for slowing down has surfaced and manifestos for slow scholarship, reading, pedagogy, professors have emerged. The fast-slow dualism seems to be of pivotal importance in the ongoing criticism of neoliberal universities. The authors share concerns expressed by 'slow professors', but at the same time they argue that slow movement in the academia reestablish a problematic dualistic approach. In the text criticism of binary conceptualisations is offered by arriving at ethical considerations (instead of tactical). The article is inspired by Donna Haraway's plea to 'stay with the trouble' (2016) to uncover the complex temporalities of the present and - possibly its subversive potential. Furthermore, while staying in this troublesome moment, the authors investigate temporal ontologies through the works of Gilles Deleuze and Félix Guattari (2007 [1980]), Henri Lefebvre (2004) and Barad (2012) - as well as the temporalities implied in the 'slow science movement'. Finally, the video art by Bill Viola is considered as a way of accessing problematics of shifting between 'fast' and 'slow'.
\end{abstract}

Keywords: slow science, ethics, new feminist materialisms, slow motion, university, neoliberalism

\section{INTRODUCTION}

This article is part of an ongoing series of conversations between the two authors - face-to-face in Warsaw, in Copenhagen and on Skype. In these conversations, we explore different possibilities for thinking through new materialist theorising and concepts, simultaneously examining the conditions of becoming/being/living/researching/teaching within academia, as well as the practices of academics, be it teaching and learning, researching, doing theory, practising thinking, discussing, engaging with theory, ideas, students, fellow researchers, selves, friends, family members, technologies, environments ${ }^{1}$.

Engaging with the new materialist conceptual framework, we wanted to approach the question of the $\mathrm{im} /$ possibilities of living live-able, learn-able, teach-able, and response-able academic lives in the current political climates. As stated by Rick Dolphijn and Iris van der Tuin, (2012), new materialisms are, among other things, 'pushing dualisms to an extreme' (Bergson [1986] 2004: 236). Dualisms such as body-mind, nature-culture, humananimal, organic-inorganic, theory-practice, are revisited to grasp the movement of differentiation, entanglements, and relationality. New materialist scholarship engages with capturing the beyond of dualisms and/or with tracing the conditions of $\mathrm{im} /$ possibilities of dualisms (new materialism is, of course, not alone in this). With relation to

\footnotetext{
${ }^{1}$ Our collaboration was made possible through the COST action 'New Materialism. Networking European Scholarship on 'How matter comes to matter". We presented a paper on the subject matter of this article, at the $7^{\text {th }}$ Annual Conference on the New Materialisms. Performing Situated Knowledges: Space, Time, Vulnerability, in Warsaw, 21 23 September 2016. Monika Rogowska-Stangret's contribution is funded by the grant from the Ministry of Science and Higher Education in Poland in the frames of the "National Programme for the Development of the Humanities" (2016-2019).
}

1 Associate professor at University of Aarhus, DENMARK

${ }^{2}$ Post-doctoral researcher at the Institute of Philosophy, $W$ arsaw University, POLAND

*Corresponding Author:malou@edu.au.dk 
living the academic life - taking into account the associated movements, sensations, and temporalities - we pose the question: Is there anything left of oppositional approach: in theory, in analysis, and in practice?

Along these lines, we investigate a dualism that has been haunting university life for some time: the duality of 'speeding up' and 'slowing down', of so-called 'fast' and 'slow' science. We want to address the temporal ontologies that drive and haunt university life and some of their possible effects. The tempo, the rhythms ${ }^{2}$, shape academic bodies and lives by shaping and orchestrating the processes we engage in, be it teaching and/or researching, and the 'products' that we as academics deliver ${ }^{3}$. We find this prism of fast-slow intriguing and important. Firstly, because the fast-slow dualism seems to be of pivotal importance in the ongoing criticism of neoliberal universities and in the process of searching for remedies. Secondly, we find the dualistic approach to fast-slow problematic, and theoretically and analytically underdeveloped. Finally, when thinking about movement, binary oppositions such as fast-slow seem to contradict the very nature of the imperceptibility of movement (as observed by Deleuze and Guattari 2007 [1980]: 280).

Furthermore, we aim to arrive at some ethical considerations (instead of tactical). We do not want to give advice, and we do not have solutions to offer, because at this point we want to direct our attention to this moment we are in and let it be or let us be in this moment. The analyses we offer are designed and performed as a way of 'staying with the trouble', which 'requires learning to be truly present, not as a vanishing pivot between awful or edenic pasts and apocalyptic or salvific futures, but as mortal critters entwined in myriad unfinished configurations of places, times, matters, meanings' (Haraway 2016: 1). This learning, we claim, is not about choosing adequate tactics or strategies, but about forming what might be a 'sensible attitude' (Haraway 2016: 4), which, as we propose, is linked to a rethinking of the ethical potentials embedded in discussions regarding fast and slow. The turn to ethics is linked to our effort to move and transform the very foundation for debates regarding the conditions of working in academia in the $21^{\text {st }}$ century by reconsidering a binary approach to fast and slow and introducing a new setting for thinking about speed, pace, and tempo in contemporary universities.

Throughout this article, we often mention ontological aspects of our inquiries, moreover, we closely link the ethical with the ontological. It is important to underline here that the turn to ethical thinking, rather than strategic or tactical, is from our perspective related to an ontological task - to create a 'sensible attitude' and 'stay with the trouble' (ibid.), as we need to consider the world in which this particular approach might be possible. We need to imagine the world in which the question of fastness and slowness might be reformulated. It is only through thinking ontologically, through reimagining the world, that we may also change the framework of the fast-slow debate in academia and offer a novel, ethical perspective. As Elizabeth Grosz underlines: 'all our actions presuppose a world, worlds, in which those actions are both viable and capable of signification and effectivity' (Grosz 2005: 128). As such, ethical actions that we develop in this paper need a world in which they matter.

We do not position ourselves as critics of the slow science movement; however, we are hesitant when noticing how slow universities and slow professors are merely presented as a response to fast science, and thus as intrinsically reactionary. By investigating the rules of the fast-slow dualism, we wish to reorient our attention to see the pitfalls and limitations on both sides of this binary and, simultaneously, by staying with the trouble, we seek to imagine things otherwise - beyond fast and slow conceived as oppositional stances. Disassembling oppositional thinking is a way of exploring in this article to pursue a pace of our own.

It is also worth stressing that we mobilise an affirmative reading of the slow science movement. We are by no means dismissive of such approaches, but want to think-with it, engage-with it based on what we consider our academic response-ability. We are well aware that, in the following deliberations, we do not cover every aspect of the slow science movement. As pointed out by Ewa Domańska in her opening keynote lecture, Slow Science and Emergent Methods in the Humanities and Social Sciences', the slow science movement emerged as a way to do justice to the quality and reliability of research and take responsibility for disseminating and understanding its outcomes and implications. Moreover, Domańska links slow academic initiatives with their critical potential, illustrating this with the example of an 'informal research centre' established in Warsaw in 2009: The Wolny Uniwersytet Warszawy (the Free/Slow University of Warsaw), guided by its slogan: "wolny, bo powolny" (freedom through slowness) (Domańska 2016). We do not address the inequalities between Western and Eastern Europe, Global South and

\footnotetext{
2 Throughout the article, we use words such as 'rhythm', 'pace', and 'tempo' interchangeably, although we are aware of the fact that each of them may point to a slightly different meaning. 'Pace' and 'tempo' are related to the question of velocity, whereas 'rhythm' refers to a certain regularity and repetition. According to Lefebvre and Régulier, however, it cannot be any repetition, but 'strong times and weak times, which return in accordance with a rule or law (...) recurring in a recognisable way (...) must appear in a movement' (2004: 78).

3 The fact that different paces and rhythms that shape and organize our working environment also form bodies, individuals, products of their work, etc. is far from a novel insight. The work of Michel Foucault (e.g. 1995 [1975]) on disciplinary society and Gilles Deleuze (e.g. 1996) on control society are just two examples of this trend.

${ }^{4}$ The keynote was given at the "7th Annual Conference on the New Materialisms. Performing Situated Knowledges: Space, Time, Vulnerability" in Warsaw on 21 September 2016.
} 
North, nor economic and class imbalances that matter especially with relation to academic positions (tenured or temporary) that reappear in the debates surrounding the slow science movement; not that we think them irrelevant in this context, but our priorities in this article lie elsewhere. Paying attention to the difficulties attached to the dualistic thinking about the academy is a way to shed new light on discussions about the pace of living an academic life in the current part of the $21^{\text {st }}$ century.

\section{TEMPORAL ONTOLOGIES OF THE UNIVERSITY}

As a response to 'the (fast) neoliberal university' - that is, the demand for an increasing working pace, a neverending series of reforms and changes, and the submission of all domains of university activity to principles of accounting and justification (Brown 2011: 113) - a cry to 'slow down' has surfaced, and manifestos for slow scholarship, slow reading, slow pedagogy, slow professors, have emerged (Berg and Seeber 2016, Mountz et al. 2015, Bird Rose 2013, Stengers 2011, The Slow Science Manifesto 2010, Alleva 2006).

The call to 'slow down' is a cry from (within) an academia that has picked up speed due to, possibly, forces of neoliberalisation and marketisation, as well as ongoing globalised reform practices. University reforms reconfigure time (Brøgger 2015) and reforms as travelling standards shape university practices of 'implementing' reforms and of leaving behind a past, fixing a future-to-come of 'deliverance' (Guyer 2007 in Brøgger and Staunæs 2016: 233):

Time is played staccato by these [reform] standards. Duration is shortened and intensified. Time passes quickly. Time is running and one can run out of time. You can lose time. Time goes by. Time is not coming. Time passes. Time is a scarce resource, so it needs to be taken care of and used in timely fashion. Time needs to be planned, calculated, ordered, and disciplined. Time is and needs to be economized. Time is consumed. Time is under pressure. Time is running out of breath. (Brøgger and Staunæs 2016: 232-233)

Academia lives through an 'ontology of calculation' (Brøgger and Staunæs 2016: 233, thinking with Guyver $2007^{5}$ ); a specific sort of present as futuring, conditioned by planning and calculating time. Brøgger and Staunæs report, based on interviews with academics, how reform processes cause nauseating affects as temporal ontologies collide through the bodies of the academics. In affective terms, losing time, wasting time, managing time, stealing time, time shortages, having no time - all come with fears, a sense of loss, unlive-able life in the world of 'emergency as rule' (Thrift 2000 in Gill 2009), which transforms scholars' lives into a state of constant alert, readiness to work, and availability - alertness becomes routine.

Nausea is only one example of how bodies react when overwhelmed by excessive stimuli. Other authors (e.g. Gill 2009) report different kinds of health problems, including chronic fatigue syndrome, burnout, exhaustion, insomnia, anxiety, and stress. It is possible to interpret this wide range of ailments using different theoretical approaches. On the one hand, as pointed out by Rosi Braidotti, we might understand such bodily reactions as how our bodies choose to convey a simple message to us: this is too much, 'one has reached the threshold of sustainability' (Braidotti 2006: 158-159). On the other hand, however, 'the individual is not only forming the neoliberal system ideologically, but they are also attuning to it organically' (Rogowska-Stangret 2017: 14). This can be exemplified using the work of Elizabeth A. Wilson on how, in cases of bulimia, 'the gag reflex itself may be attenuated' (Wilson 2004: 79) to the point where it disappears entirely. Both approaches attest to the fact that bodies do not only oppose neoliberal academia, but also collaborate with it and conform with the growing demands of academic life. After all, people do generally sleep less than previously (Crary 2013).

As noted by Sharon Traweek, even research results, as they are reported and published, contribute to what we may consider a compression of time, or an annulment of time. The results presented by the particle physicists in the United States and Japan studied by Traweek are tidied up to be 'free of ephemeral time' (1988: 157), even though: "In the course of a career a physicist learns the insignificance of the past, the fear of having too little time in the present, and anxiety about obsolescence in the face of a too rapidly advancing future" (Traweek 1988: 17). All the hard work that went into enabling 'results' (grant applications, experiments, data production and analysis, developing and dismissing theories, consulting with colleagues, engaging with other researchers' results, and so forth) is made invisible, 'at the end of the day or project, the product of the physicists' activity is freed from any marks of this work' (Schrader 2012: 119). These mechanisms do not apply solely to physicists, but resonate with, and might be also used to investigate, products of the work of researchers in other academic disciplines. This adds a layer of possible temporal dis-orientation in the lives of researchers, as the sense of the labour of the process may somewhat linger on as they move on to the next task, and the next, and the next.

\footnotetext{
${ }^{5}$ In her article "Prophecy and the near future: Thoughts on macroeconomic, evangelical, and punctuated time", Jane I. Guyver does not analyse academia, but reads diffractively through temporal perspectives within US macroeconomics and evangelical understandings of time; hence the point about calculation.
} 
One might say that the 'ontology of calculation' (Brøgger and Staunæs 2016: 233, thinking with Guyver 2007) colonises our futures, 'emergency as rule' (Thrift 2000 in Gill 2009) nullifies our presents, and our fixation on development, improvement, and reform obliterates our pasts. We do indeed have no time! The slow science movement is a response to these, and a number of other conditions of being of the university. When examining slow science, and the answers, solutions, remedies, and suggestions that it offers, however, we have found it to have certain limitations, and we therefore offer a respectful diffractive reading of the slow science movement.

\section{STAYING WITH THE SLOW OF THE SLOW SCIENCE MOVEMENT}

Many authors, such as Isabelle Stengers, Deborah Bird Rose, and the Great Lakes Feminist Geography Collective, to name just a few, recognise the problematic nature of fast science. While searching for solutions and tracing the contours of a revolution, they formulate a demand that academics be allowed to perform both slow and fast science, to change registers:

'I decided to divide my work into fast work and slow work. The two are not wholly separable, but the major difference, in my mind, is that fast work is strategic and slow work is dialogic' (Bird Rose 2013: 9);

'Don't get us wrong - we do say yes to the accelerated science of the early $21^{\text {st }}$ century. We say yes to the constant flow of peer-review journal publications and their impact; we say yes to science blogs and media \& PR necessities; we say yes to increasing specialization and diversification in all disciplines. [...] However, we maintain that this cannot be all' (The Slow Science Manifesto 2010);

'I am [...] aware that no university today is free to escape the rules that make fast, competitive, science a matter of life and death. That is why I wish [...] to emphasize the difference between, on the one hand, adhering to a rule and, on the other, recognizing its power while looking for the opportunities to experiment outside its bounds, creating interstices where another science could discover its own demands' (Stengers 2011: 12-13).

Thus, academics are encouraged to be 'smart' - to move within the bounds of the given possibilities, to manoeuvre past obstacles in order to accommodate the demands of both paces - fast and slow. We recognise these strategies as an effort to try to start from our current position, to adequately recognise the existing situation and, on this basis, search for possible ways of making a difference, for the sake of academic quality and out of a sense of responsibility for future generations and the world as such. The aforementioned authors often recognise a need for radical revolution and seek to establish conditions that enable actions, which might stimulate revolutionary potentials. This can be seen in Stenger's plea for slow science: 'Another science is possible!' or in the aims articulated by members of the Great Lakes Feminist Geography Collective: 'slow scholarship cannot just be about making individual lives better, but must also be about re-making the university' (Mountz et al. 2015: 1238), 'We argue for a fundamental restructuring of the university' (p. 1248), and 'the time is ripe for radical change' (p. 1249).

Nevertheless, doing both fast and slow science can also reaffirm the existing situation, maintaining it and collaborating with it; indeed, it means inscribing the slow with the demands and tempo of the fast or - better put - finding a slow disguise for the fast. We want to direct our attention to 'staying with the trouble' rather than finding a quick and easy solution, because any apparent solution, however caring and attentive its intentions, may be all too easily consumed by fast approach. As expressed by Michel Foucault: 'every strategy of confrontation dreams of becoming a relationship of power' (1983: 225-226).

This movement of covering up the 'fast approach' under a 'slow disguise' can be exemplified by good advice carefully considered, lived, and passed on by authors with the intention of helping other scholars manage their time and tackle the shift from fast to slow and vice versa. In For Slow Scholarship: A Feminist Politics of Resistance through Collective Action in the Neoliberal University (Mountz et al. 2015), academics are advised to: discuss and support the slow movement, include the invisible in evaluation processes (e.g. time spent on caring for others), organise collectively and create a community of slow scholars, emphasise care ('Do not shy away from talking about life, and how intertwined life and work are' (p. 1251)), write fewer emails ${ }^{6}$, stay offline (e.g. refuse to respond to emails at all hours), take time to think and to write (differently), say no when necessary, agree when there is an opportunity to bring about change and introduce slow strategies, become minimalist (i.e. 'good enough is the new perfect' (p. 1253)). Similarly, in Slow Professor: Challenging the Culture of Speed in the Academy, Maggie Berg and Barbara Seeber advise fellow scholars to, among other things: get offline, do less, organise 'regular sessions of timeless time', do

${ }^{6}$ See more advice on this particular issue here: http://emailcharter.org/. 
nothing, 'change the way we talk about time all the time', 'remember the values of density, complexity, and ideas which resist fast consumption', 'make time for (...) 'Unintentional Knowledge: what we find when we're not looking", 'take the time to read things that we do not 'have to' read', 'follow our hearts', 'keep calm and write on', vent from time to time to avoid whining, and 'risk candour'.

These pieces of advice might have been helpful at some stage (to draw attention to the accelerating academy and recognise its 'hidden injuries' (Gill 2009), thereby addressing what is excluded from the 'official' story about life in the academy) and they still might help us in managing our time in the fast academy, coping with the demand to speed up while being also critical of it. Most of the advice is written to help stimulate, introduce, and lay the foundations for a new academia; more responsible for futurity, more collaborative, healthier, more thoughtful, more caring, and with higher academic quality. This attempt to find niches where one is able to make a difference should be appreciated.

The questions that keep haunting us when dwelling on these matters are, however, numerous. In this article, we will limit our attention to focus on the claim - expressed in the aforementioned literature - that it is possible to do both-and. We want to consider bodies and rhythms, their im/possibilities and their ir/regularities, and the idea that it is (non-)humanly possible to shift between slow and fast at an ever-changing pace.

We ask: how is it possible to do both fast and slow science, and how quickly can we switch between these registers? What does it mean to change from fast to slow and vice versa? What does this change/ transformation look like? This is also linked to the question of conditions enabling changes: how can we introduce modifications, variations, or shifts at the organisational, political, institutional, or psychological level without repeating what is given or falling in pitfalls of the conditions we oppose?

\section{RHYTHMANALYSIS OF THE FAST-SLOW ACADEMIC LIFE}

Looking at university life (as a whole), it seems like it is not a question of a single transition between fast and slow. As multiple rhythms exist at any given time, there is an expectation of a human ability to rapidly 'switch' between and among rhythms; to be polyrhythmic, or even to harmoniously combine disharmonies, to be a kind of 'transition box' that changes 'arrhythmia' into 'eurhythmia' (Lefebvre 2004). So, let's stay with this idea of rhythms for a moment, to see what sort of explanatory/analytical power it may give to the tempo and fast-slow question.

Lefebvre writes that 'energy' is movement - it is that which enables interaction of time and space. Time, space, and energy are specifically formed through a rhythm - and through the relationships, differences, and specificities of co-existing rhythms - rhythms flowing through bodies and affecting them. Rhythms have spatial, material, bodily, and affective qualities. In developing rhythmanalysis, Henri Lefebvre works with subcategories such as 'polyrhythmia', 'eurhythmia', and 'arrhythmia'. This is relevant because it conceptualises the specificities of how rhythms may flow through, 'hit', and modulate the body. Arrhythmia is the term for the state of following conflicting rhythms. It means the dissonance between or among two or more rhythms. It is a sort of pathological state, where the multiplicity of rhythms produces 'fatal desynchronisation': a divergence in time, in space, and therefore in the use of energies (Lefebvre 2004: 68). Chronic fatigue syndrome, burnout, exhaustion, insomnia, anxiety, and the like, as mentioned earlier, are examples of what Lefebvre terms arrhythmia. Furthermore, if trying to follow his and Régulier's somewhat sketchy steps towards an alternative to psychoanalysis (rhythmanalysis as 'therapy', see Lefebvre, Régulier 2004), one can imagine how they might approach these conditions (exhaustion, insomnia, etc.) by addressing the multiplicities of rhythms and how they interfere and collapse. One could also think with this idea in terms of an 'individual' or 'dividual' matter, or one could think of it as an organisational or collective matter of sensing, addressing, and questioning disturbance patterns and affective qualities and specificities. This would then, in our imagination, be a specific space of staying with the troubles; that is, 'rhythmtherapy' as a space of being and unravelling, not 'solving'.

We are done by/parts of multiple rhythms at any given time. Some of the rhythms, our involvement is more 'direct'; others less so. For example, to be near the bodies of other people who either struggle with transitions or perhaps are (momentarily) stuck at one pace (speed-speed-speed) affects 'you' even though it is not (in a humanist sense) 'you'/your body. Your body and your nervous system does not end and begin at the borders of your own flesh (everybody is 'more than one and less than many' (Strathern 1991: 35 cited in Swanson et al 2015: 1507)). When you see the suffering of others, it hits your sensory registers. When listening to a voice that is tense with speed/stress, the sound waves of distress flow through 'your own' system. There are constant, multiple rhythms and movements that everybody is part of becoming with and of at any given time and place.

There is a conceptual play between movement and 'to be moved'; 'to be moved' in the sense to be affected, pushed, pulled beyond any control by the specific beats and rhythms. Being moved may be both energising and

\footnotetext{
${ }^{7}$ Strathern (1991), though, writes "One is Too Few but Two are Too Many" (p. 36), so probably Swanson et.al are the ones
} to be credited with the phrase. 
exhausting. So how much movement and what qualities of movement can our bodies bear? How many bodies may one be/become before it becomes too much? Addressing these questions is a matter of empirical, relational specificities, as the specificities of what may be sensed as slow and fast (and as 'too much') are a matter of what other movements and rhythms are around and interfere, interplay, diffract with others. There must be more rhythms of 'a' body (more bodies of one...?) in order to sense different paces. Following Barad (2007), one might say that it is a matter of the intra-actions (that always come to be as specificities); it is only possible to determine the quality in the agential separability, the 'cutting together apart' which is the agentially enacted material conditions of exteriority-within-phenomena (Barad 2014: 177). It is inherently relational - and multiple - while entangled in nature.

When thinking about the richness of the rhythms that percolate through us, a plethora of intra-actions that attest to the relational character of the world, the immensity of paces shaping the matter of life itself, we might want to pose a question of the (emotional, bodily, social, cultural, institutional, etc.) limits associated with this intense multitude, its regularities and irregularities (and their effects on us), and return to the 'slow movement' as a way to address relationalities, affectivities, and excessiveness of living an (academic) life. It is no coincidence that this cry for slowness arises. Lefebvre and Régulier state that, "We are only conscious of most of our rhythms when we begin to suffer from some irregularity" (Lefebvre and Régulier 2004: 77). So, as what is sensed is the acceleration - and its nauseating effects, among other things - an orientation towards questions of pace seems obvious, asking when and how 'speed' may be counteracted or combined with 'slowness'. But, still, what actions do switching between fast and slow involve? We tried to experiment with this question.

\section{SLOW AND SLOW-MOTIONING}

The video artist Bill Viola is famous for producing slow-motion film clips. We agreed to watch his work in order to try to engage with what slow-motioning might be like as art, as a metaphor, as a practice, as bodily becoming - that is, as becoming bodily while watching the video art $^{8}$.

A very short presentation of the works we watched is appropriate at this juncture. The first is entitled The Raft (Viola 2004) and is a 10-minute piece showing a group of people, positioned as if waiting at a bus stop, each minding their own business; they are strangers to each other. Suddenly, a large, forceful stream of water is directed at them, coming from the sides, totally engulfing them. Some manage to stand on their feet; others are forced to let themselves fall to the ground. They are turned into a sort of collective entity of water-bodies for a while, and then the water becomes still and the viewer sees them return to their senses, some helping others get back up, some hugging one another, some standing alone, before leaving the scene one by one. The whole sequence occurs in slow motion - displaying every bodily micro-movement and micro-expression and the changes in the emotional expressions writ upon the group's faces, from bored to shocked to despair. The other piece we watched is not Viola's own work, but was created by the art collective We Are Frilly (http://wearefrilly.com/blog/2013/9/10/faces-a-bill-viola-experiment) and called Faces - a Bill Viola experiment. This film lasts half an hour and shows 26 people, one by one, placed in front of the camera and then filmed whilst their families and friends provoked reactions from them. The video only displays the 'models' and, as the soundtrack is also slowed down, the atmosphere of the soundscape is strange, metallic, robotic/monstrous, unearthly, and definitely not human-like. Each encounter lasts approximately $1 \frac{1}{2} 2$ minutes, and we are faced with people of different ages and genders, as well as ethnic-racialised differences.

We watched these two pieces at different occasions. And we discovered that our bodily and psychological ability to watch - that is, of staying with the slow-motioning - was quite determined by when we watched the films. Watching before summer holidays and watching a month after finishing the holidays resulted - as one of us reported - in 'the urge to speed up the films and checking emails, open a newspaper, think about other duties' and there appeared to be a 'need to cover the film with layers that will speed it up: I'm thinking of something else, switching off, dropping off, detaching myself from the pace I cannot bear. Otherwise there emerged a feeling of both organic disorder and psychological distress'. Another mode of watching slow motion was to feel overwhelmed by the obligation to do so - and, as a result, one of us gave up the project and stopped watching the films.

Watching just after holidays, meanwhile, enabled a different intra-action of video and body. One of us experienced that with the film Faces - while before her holidays she could only bear to watch the film for less than 2 minutes, afterwards, she was able to watch the whole 30 minutes, even feeling that it could have lasted longer.

\footnotetext{
8 We picked two films: The Raft (2004: https://vimeo.com/13920952) by Bill Viola and Faces (2013: https:/ / www.youtube.com/watch?v=gD07j1ZIrw8) by the We Are Frilly collective.
} 
The other still rushed the watching, but now out of an eagerness to begin working on this article (somewhat ironically...)!

The point here is not to analyse our individual working lives (nor is it to perform an organisational analysis of the different tasks involved in an academic career, with all its specificities - including carefully addressing the inequalities between Western and Eastern Europe, Global South and North, these areas have economic and class imbalances that are effected by different academic positions (tenured or temporary)), but to consider the fast/slow dualism, heed the cry for a slowing down - and the conditions of im/possibility of transformation - it seems that the idea of this ability to shift from fast to slow and back is founded on a dualist premise, that of two separate entities of being. Switching without transitions or transformations, gaps or overlaps, what would it mean to push this fast-slow dualism to the extreme? Would doing so reveal the imperceptible nature of movement? Our experiment suggests an im/possibility of switching, i.e. an im/possibility to simply redirect attention from fast to slow, from slow to fast, without the slowness lingering in the fast-mode and without speeding up that stays in the background when slowing down. How voluminous are we ('actually') in terms of transitions (if considering fast/slow not to be entities or opposites, but instead, as ontologically entangled)? How many rhythms are we capable of embracing without falling into 'morbid and then fatal de-synchronisation' (Lefebvre 2004: 68)? What enables transition? What happens at the point of transformation? How is it possible?

Slow-motioning plays with the fluidity, imperceptibility, and infinity of movement; it opens up a space to zoom in on the moment of transition, to have a sense of what eludes our perception. Speeding up has similar effects speeding up transforms the fluidity, imperceptibility, and infinity of movement into lines. Becoming, as explained by Gilles Deleuze and Félix Guattari, has its ends in becoming imperceptible: 'one is no longer anything more than an abstract line' (Deleuze, Guattari 2007 [1980]: 280). From this perspective, fast and slow are indistinguishable. It opens the possibility of being both 'below and above the threshold of perception' (Deleuze, Guattari 2007 [1980]: 281). So, let's zoom in closer on the points of transition.

Another mode of investigating is to consult the technical aspects of slow-motioning - what does it actually entail, to slow motion when producing moving images, be it film or video? According to the Danish film director and producer Kristoffer Nyholm, when shooting for use in slow motion sequences, you need to record at a quality enabling an extra amount of images per second so that the subsequent slow motioning will be smooth. In a film, one second of footage consists of 24 images; as such, a movement can be said to comprise a specific number of images. When shooting for slow motion, however, one needs to create more images of the movement, even as many as 200-300 images per second (depending on the level of slowness one wants to accomplish). One then plays the movement/activity with a standard film image per second of 24 images, prolonging the movement. Effectively, this second is then a different sort of second as its relation to the viewer's sense of movement-second is out of sync within the sequence. (With a smaller amount of still images to work with, you get lower quality slowmotioning, as the individual image is 'stretched' in time, which results in distortion of the images, visible to the keen eye) (Nyholm in personal conversation 2017). Understood metaphorically, then, slow-motioning is not a process of simply rewinding and slowing down what was filmed; nor is the common-sense understanding of slowmotioning as simply doing something more slowly than normal accurate. In Nyholm's words, one is able to register lapses, or temporal between-nesses. Slow motion is then not a matter of recreation, but a re-creation; to enable slow motion is to open for a state of intense awareness: an intake of 'more' - not of 'the same' at a slower pace. It is an extreme intensity of being (that one is not supposed to sense in the first place), an added spatio-temporalaffective being that one may not be able to digest, depending on which other rhythms one is becoming of at that

\footnotetext{
${ }^{9}$ At a late stage in the process of writing this article, we discovered an article entitled Spacing organization: non-representational theory and performing organizational space by Timon Beyes and Chris Steyaert, influenced by The Raft. It is interesting as it attests to an altered sense of being as an effect of watching the film. Beyes and Steyaert write: "I take a deep breath when I remember the deep breath I took when this video was over. I felt stirred up, and so did the other viewers in the dark museum room who only slowly left for the next part of the exhibition. I walked out conscious of my own walking, my own mood and my own sensation of the dark room. As if I wanted to walk in slow motion. Yet my body walked me through the corridor without running into anybody else and into the garden of the museum from where you could see how calm the sea was on that day. Some of these feelings of intensity come back on this rather quiet afternoon, where my colleagues have in the meantime returned from lunch. Viola provides 'turbulent surfaces' in which emotional and physical shape coincide in arcs of intensity (Thrift 2004: 73). When I reread my own text [describing the video and the bodily and spatial experience in relation to watching it], my finger goes to the delete-key, as I think this description is too meager to suggest something of the ecstasy of the slowly turning narrative Viola produced in image and sound. Something blocks in my finger, and, with a sigh, I pass through my office door, in a hurry to get a sandwich" (Beyes \& Steyaert 2012: 47). This account is also interesting for the hunches of the $\mathrm{im} /$ perceptibility of transformation between speed and slowness that we are investigating in this article. Beyes and Steyaert (implicitly) address the temporal entanglements of an intense bodily experience; the deep breath reaction of two different spatio-temporal moments, the re-sensing of the event.
} 
moment in time ${ }^{10}$. In that sense, this way of considering slow-motioning also disturbs the dualist understanding of slow and fast: the slow is fast in its 'muchness' and the fast is slow in the sense that it is skirting through events (images, movements, meanings, sensations) in ways that are not engaging, or may only engage through gaps of presence.

\section{GAPS OF (NON-)PRESENCE}

Let's consult Bill Viola on the matter. In his talk Cameras are Soul Keepers ${ }^{11}$, he states that the fluidity of movement is enabled by a gap: 'there's a gap of empty space $[\ldots]$ there's an emptiness $[\ldots]$ real thing that exists: $[\ldots]$ the space between all physical objects'. But then, what is this space in-between, the emptiness - that real thing? How to link this emptiness with the fluidity/imperceptibility/infinity of movement? When approaching these questions, Karen Barad (2012) can offer inspiration as she considers the very nature of nothingness - carefully and thoughtfully, recognising the vulnerability of attempting to approach nothingness. Barad argues that the problem of nothingness is linked to indeterminacy. Quantum field theory does not allow the vacuum (or the void) to be 'determinately nothing because the indeterminacy principle allows for fluctuations of the quantum vacuum' (Barad 2012: 9), which means that emptiness is not the ontological character/being of nothingness. There is thus no (determined) empty space. Emptiness is a sort of play with its own condition - on the verge of emptiness and plentitude, it fluctuates between nothingness and allthingness, as there is an infinite number of im/possibilities of intra-actions of the void. The fluctuating vacuum is 'doing its own experiments with non/being' (p. 8), 'the void is a lively tension, a desiring orientation towards being/becoming' (p. 13). We may comprehend it in terms of virtuality, as stated by Barad: "Virtuality is [...] the indeterminacy of being/nonbeing, a ghostly non/existence" (p. 12). Virtuality embraces what is actualised, like 'a 'cloud' of an indeterminate number of virtual particles' (p. 15) that forms an electron. There is no sheer possibility of nothingness as full, determined emptiness; rather, it is filled with what might come to existence, be actualised, or realised. This forms an ontological ground for being open towards the difference, change, transition but also for infinite potentialities to embrace all different paces, tempos, velocities - to become polyrhythmic.

\section{TOWARDS AN ETHICS OF BE/COMING POLYRHYTHMIC}

To return to the question of how to change registers, we may say that 'pure' slowing down and speeding up are impossible. The fast and slow are both ungraspable and both 'below and above the threshold of perception' (Deleuze, Guattari 2007 [1980]: 281). As such, the question to be asked in terms of fast and slow academia is not how to manage time to do both, how to deal with that, how to approach it tactically, or use oneself to handle contradictory requirements, but instead, how to encourage oneself to embrace the virtuality - below and above oneself, how to experiment with im/possibilities, with non/being, so that we could not 'react differently to different [conditions, in the original: probings] but be differently' (Barad 2012: 6).

Importantly, this is not a return to a vision of academics required to synchronise arrhythmia into eurhythmia. We are talking here of embracing the virtualities of every rhythm to be or become polyrhythmic. This time, however, it is an ethical project, because in our view, the (arguments of the) slow movement is situated within the same ontology as the temporal ontology of the (neoliberal) university. It is about 'finding time', it is imposing with its demands on academics to manage time manage oneself, smarter. It is a remedy. It is about taking medication; it is a piece of advice and not a transition. What we find lacking, and what we would like to offer instead of advice, is a call to stay at the ontological level, a call for ethics. We do not need to use the same - already crazy - time better. We need ethics to form and cherish our polyrhythmic bodies.

As mentioned at the beginning of this article, we consider dwelling upon im/perceptibilities of fast-slow transformations (within the current climate of struggling to live liveable feminist academic lives) and staying at an ontological level that enables ethical and not tactical thinking. Working on this very paper - mostly through Skype conversations - was also a way of staying with the trouble of being and working in different cities, universities, together and alone, confronted with dissimilar life circumstances, faced with varying personal and professional challenges, manoeuvring our calendars to be able to meet online and engage with thinking together, making efforts to meet the deadlines and requests of our editors and reviewers, patiently assisting one another in 'stuck places'

\footnotetext{
${ }^{10}$ As such, a movie could, in Russian filmmaker Andrei Tarkovsky's words be sensed to be the ability to create time within time: "The cinema image comes into being during shooting, and exists within the frame [...] Editing brings together shots which are already filled with time, and organizes the unified, living structure inherent in the film; and the time that pulsates through the bold vessels of the film, making it alive, is of varying rhythmic pressure" (Tarkovsky 1989: 114).

11 (From Louisiana Channel: http://channel.louisiana.dk/video/bill-viola-cameras-are-keepers-souls; it starts around minute $4: 50)$.
} 
(Lather 1998), sharing our struggles and joys, infecting one another with laughter and tears, affecting each other with different rhythms and paces, trying to materialise - in this very piece of writing - the pace of our own. Neither fast, nor slow. Just our own.

To ponder for a moment over our experiment with our reactions to Bill Viola's video art: both reports attest to the fact that the affective experience is unmanageable; it does not coincide with our expectations, willingness, or plans. Slow-motioning confronted us with the unmanageable; with what eludes the tactical approach, showing that it is impossible to smoothly shift registers from fast to slow science and vice versa. It moreover confirms the affective nature of the experiment itself. As claimed by Gregory J. Seigworth and Melissa Gregg in their An Inventory of Shimmers, 'affect is integral to a body's perpetual becoming (always becoming otherwise, however subtly, than what it already is), pulled beyond its seeming surface-boundedness by way of its relation to, indeed its composition through, the forces of encounter. With affect, a body is as much outside itself as in itself - webbed in its relations - until ultimately such firm distinctions cease to matter' (2010:3, emphasis in original). This perspective makes it apparent that clear-cut distinctions are indeed impossible and that the body and its seeming outside are simultaneously moved and move affectively, and it is impossible to determine beyond doubt which forms of becoming are desirable and which are not, which movement is slow and which is fast, which affect leads to slow science and which results in the fast approach. When attempting to address the question of pace within academia using fast-slow dualism, we overlook the affective aspect of living an academic life - ripe with unmanageable, imperceptible, indecisive, subtle 'becoming otherwise'. Furthermore, through insights from the technical aspects of slow-motioning in video and movie production, we addressed the ontological being of slow motion as a state of intense awareness: an intake of 'more' - not of 'the same' at a slower pace. We struggled to zoom in on the possibility of change and transformation and diagnosed, with Barad, that the emptiness that - as stressed by Viola - is a prerequisite for change, is never empty. On the contrary, it is filled with infinite potentialities of change, thus reformulating the question of smooth transformation into a question of embracing different modalities, $\mathrm{im} /$ possibilities, paces. Hopefully, it also hints at possible aspects - and challenges - of what learning 'to be truly present' (Haraway 2016: 1) could entail in academic life and which new approaches might emerge (enabling modifications at the organisational, political, institutional, psychological levels) instead of 'only' engaging in attempts to manage time, affects, and plans for the future (which, as we sought to demonstrate, merely reaffirms the status quo and fails to avoid the pitfalls of the conditions we oppose) ${ }^{12}$. This might be a good starting point to think ethics of living (academic) lives and to allow the polyrhythmic multitude of ourselves/bodies be(come) different; for the sake of not just our bodies, but the bodies that are constantly impacted by the vibrations rushing through our bodies.

\section{REFERENCES}

Alleva, L. (2006). Taking time to savour the rewards of slow science. Nature, 443, 271 (21 September). Available at: http://www.nature.com/nature/journal/v443/n7109/full/443271e.html. (Accessed 27 July 2017).

Barad, K. (2007). Meeting the Universe Halfway: Quantum Physics and the Entanglement of Matter and Meaning, Durham, NC: Duke University Press.

Barad, K. (2012). What Is the Measure of Nothingness? Infinity, Virtuality, Justice/ Was ist das Maß des Nichts? Unendlichkeit, Virtualität, Gerecbtigkeit, Documenta 13, 99, Kassel: Hatje Cantz.

Barad, K. (2014). Diffracting Diffraction: Cutting Together-Apart. Parallax, 20(3), pp. 168-187. https://doi.org/10.1080/13534645.2014.927623

Barad, K. (2016). Troubling Time/s: Undoing and Re-membering The Future, The Future Lecture Series, 25.10.2016, Aarhus University.

Berg, M. and Seeber, B.K. (2016). The Slow Professor: Challenging the Culture of Speed in the Academy. Kindle edition. Toronto: University of Toronto Press.

Bergson, H. ([1986] 2004). Matter and Memory. 5th ed., Transl. N.M. Paul and W.S. Palmer, Mineola, NY: Dover.

Beyes, T and Steyaert, C. (2012). Spacing organization: non-representational theory and performing organizational space. Organization, 19(1), pp. 45-61. https://doi.org/10.1177/1350508411401946

Bird Rose, D. (2013). Slowly writing into the Anthropocene, TEXT Special Issue 20, M. Harrison, D. Bird Rose, L. Shannon, K. Satchell (eds). Available at: http://www.textjournal.com.au/speciss/issue20/Rose.pdf. (Accessed 27 July 2017).

Braidotti, R. (2006). The Ethics of Becoming Imperceptible. In: C. Boundas, ed., Delenze and Philosophy (pp. 133159). Edinburgh: Edinburgh University Press.

\footnotetext{
${ }^{12}$ We are paraphrasing Haraway's words. Obviously, Haraway is engaged in very different processes than we are here, and we do not intend to disrespect or to disturb the specificities of the political intensity and impact that her phrase is designed to have.
} 
Brown, W. (2011). Neoliberalized Knowledge. History of the Present: A Journal of Critical History, 1(1), pp. 113-129. Available at: http://interimprovost.ucdavis.edu/local_resources/docs/20150520/Brown_NeoliberalizedKnowledge.pdf (Accessed 27 July 2017).

Brøgger, K. (2015). The faceless master of higher education. New Standards - New Normals. Educational Standards in the (Un)making. The case of higher education reform. PhD Dissertation. Copenhagen: Aarhus University.

Brøgger, K. and Staunæs, D. (2016). Standards and (self)implosion: how the circulation of affects accelerates the spread of standards and intensifies the embodiment of colliding, temporal ontologies. Theory \& Psychology, 26(2), pp. 223-242. https:// doi.org/10.1177/0959354316635889

Crary, J. (2013). 24/7: Late Capitalism and the Ends of Sleep. London: Verso.

Deleuze, G. (1996). Negotiations 1972-1990. New York: Columbia University Press.

Deleuze, G. and Guattari, F. (2007 [1980]). A Thousand Plateaus: Capitalism and Schizophrenia. Transl. B. Massumi. Minneapolis: University of Minnesota Press.

Dolphijn, R. and van der Tuin, I. (2012). New Materialism: Interviews \& Cartographies. Ann Arbor: Open Humanities Press.

Domanska, E. (2016). Slow Science and Emergent Methods in the Humanities and Social Sciences, opening keynote lecture at the "7th Annual Conference on the New Materialisms. Performing Situated Knowledges: Space, Time, Vulnerability" in Warsaw on 21 st September 2016.

Foucault, M. (1983). The Subject and Power. In: H.L. Dreyfus and P. Rabinow, eds., Michel Foucault: Beyond Structuralism and Hermeneutics, (pp. 208-252). Chicago: The University of Chicago Press.

Foucault, M. (1995 [1975]). Discipline and Punish. The Birth of the Prison. Transl. A. Sheridan. New York: Vintage Books.

Gill, R. (2009). Breaking the silence: The hidden injuries of neo-liberal academia. In: R. Flood and R. Gill, eds., Secrecy and Silence in the Research Process: Feminist Reflections (pp. 228-244). London: Routledge.

Grosz, E. (2005). Time Travels. Feminism, Nature, Power. Durham, London: Duke University Press.

Guyer, J.I. (2007). Prophecy and the near Future: Thoughts on Macroeconomic, Evangelical, and Punctuated Time. American Ethnologist, 34(3), pp. 409-421. https://doi.org/10.1525/ae.2007.34.3.409

Haraway, D. (2016). Staying with the Trouble: Making Kin in the Chthulucene. Durham, London: Duke University Press.

Lather, P. (1998). Critical Pedagogy and its Complicities: A Praxis of Stuck Places, Educational Theory, 48(4), pp. 487-497. https://doi.org/10.1111/j.1741-5446.1998.00487.x

Lefebvre, H. (2004). Elements of Rhythmanalysis: An Introduction to the Understanding of Rhythms. In: Rhythmanalysis. Space, Time and Everyday Life (pp. 1-69). Transl. S. Elden and G. Moore, New York, London: Continnuum.

Lefebvre, H. and Régulier, C. (2004). The Rhythmanalytical Project. In: Rhythmanalysis. Space, Time and Everyday Life (pp. 71-83). Transl. S. Elden and G. Moore, New York, London: Continnuum.

Mountz, A., Bonds, A., Mansfield, B., Loyd, J., Hyndman, J., Walton-Roberts, M., Basu, R., Whitson, R., Hawkins, R., Hamilton, T., Curran, W. (2015). For Slow Scholarship: A Feminist Politics of Resistance through Collective Action in the Neoliberal University. ACME: An International E-Journal for Critical Geographies, 14(4), pp. 12351259. Available at: https://www.acme-journal.org/index.php/acme/article/view/1058/1141 (Accessed 27 July 2017).

Nyholm, K. in personal conversation with Malou Juelskjær, Copenhagen, 29 th May, 2017 (and 19th December 2016).

Rogowska-Stangret, M. (2017). Sharing Vulnerabilities. Searching for "unruly edges" in times of the neoliberal academy. In: B. Revelles-Benavente and A.M. González Ramos, eds., Teaching Gender. Feminist Pedagogy and Responsibility in Times of Political Crisis (pp. 11-24). London, New York: Routledge.

Schrader, A. (2012). Haunted Measurements: Demonic Work and Time in Experimentation. Differences: A Journal of Feminist Cultural Studies, 23(3), pp. 119-160. https:/ / doi.org/10.1215/10407391-1892916

Seigworth, G.J. and Gregg, M. (2010). An Inventory of Shimmers. In: G.J. Seigworth and M. Gregg, eds., The Affect Theory Reader (pp. 1-25). Durham, London: Duke University Press.

Stengers, I. (2011). "Another science is possible!" A plea for slow science. [online] Available at: http://we.vub.ac.be/aphy/sites/default/files/stengers2011_pleaslowscience.pdf. (Accessed 27 July 2017).

Strathern, M. (1991). Partial Connections. Savage, MD: Rowman and Littlefield.

Tarkovsky, A. (1989). Sculting in Time: Reflections on the Cinema. Transl. K. Hunter Blair. Austin, TX: University of Texas Press.

Swanson, H.A., Bubandt, N. and Tsing, A. (2015). Less Than One But More Than Many: Anthropocene as Science Fiction and Scholarship-in-the-Making. Environment and Society: Advances in Research 6(1), pp. 149-166. https://doi.org/10.3167/ares.2015.060109

The Slow Science Manifesto (2010). http://slow-science.org/. By: (c) The Slow Science Academy, 2010. Berlin, Germany. 
Thrift, N. (2000). Performing cultures in the new economy, Annals of the association of American Geographers, 90, pp. 674-692. https://doi.org/10.1111/0004-5608.00217

Traweek, S. (1988). Beamtimes and Lifetimes: The World of High Energy Physicists. Cambridge, MA: Harvard University Press.

Wilson, E.A. (2004). Gut Feminism. Differences. Journal of Feminist Cultural Studies, 15(3), pp. 66-94. https://doi.org/10.1215/10407391-15-3-66

Citation: Juelskjær, M. and Rogowska-Stangret, M. (2017). A Pace of Our Own? Becoming Through Speeds and Slows - Investigating Living Through Temporal Ontologies of The University. Feminist Encounters: A Journal of Critical Studies in Culture and Politics, 1(1), 06. https://doi.org/10.20897/femenc.201706

Copyright (C) 2017 by Author/s and Licensed by Lectito BV, Netherlands. This is an open access article distributed under the Creative Commons Attribution License which permits unrestricted use, distribution, and reproduction in any medium, provided the original work is properly cited. 
http://www.lectitopublishing.nl

https://www.facebook.com/LectitoJournals/

https://twitter.com/lectitojournals

$\mathcal{S}_{+}$https://plus.google.com/110901545130385419486

in https://www.linkedin.com/in/lectito-journals9a675010b/ 


\title{
Counting Zero: Rethinking Feminist Epistemologies
}

\author{
Xin $\operatorname{Liu} 1 *$
}

Published: October 30, 2017

\begin{abstract}
This article concerns feminist engagements with epistemologies. Feminist epistemologies have revealed and challenged the exclusions and denigrations at work in knowledge production processes. And yet, the emphasis on the partiality of knowledge and the non-innocence of any subject position also cast doubt on the possibility of feminist political communities. In view of this, it has been argued that the very parameter of epistemology poses limitations for feminism, for it leads to either political paralysis or prescriptive politics that in fact undoes the political of politics. From a different perspective, decolonial feminists argue for radical epistemic disobedience and delinking the move beyond the confines of Western systems of knowledge and its extractive knowledge economy. Nevertheless, the oppositional logic informs both feminist epistemologies and its critiques, which I argue is symptomatic of the epistemic habits of academic feminism. This article ends with a preliminary reconsideration of the question of origin through the figure of zero. It asks whether it might be possible to conceive of feminist epistemologies as performing the task of counting zero - accounting for origin, wholeness, and universality - that takes into account specificities without forfeiting coalition and claims to knowledge.
\end{abstract}

Keywords: feminist epistemologies, critique, zero

\begin{abstract}
Much of the most provocative feminist theory in the last twenty years has insisted on the ties of sex and race in ways that problematized the birth pangs of the sex/gender system in a discourse more focused on the interweaving of gender and class. It has seemed very rare for feminist theory to hold race, sex/gender, and class analytically together - all the best intentions, hues of authors, and remarks in prefaces notwithstanding. In addition, there is as much reason for feminist to argue for a race/gender system as for a sex/gender system, and the two are not the same kind of analytical move. And, again, what happened to class? The evidence is building of a need for a theory of 'difference' whose geometries, paradigms, and logics break out of binaries, dialectics, and nature/culture models of any kind. Otherwise, threes will always reduce to twos, which quickly become lonely ones in the vanguard. And no one learns to count to four. These things matter politically (Haraway 1991: 129).
\end{abstract}

For the/a woman, two does not divide into ones. Relationships defy being cut into units. And when 'she' hangs on so desperately to the one, even to the point of putting a capital letter for one god made Man, it is only so as to repeat that value 'she' has a right to upon the exchange market - the value of no value. That nil, that zero, that moving decimal place which is the basis and seal of all accountability (Irigaray 1985: 237).

\section{INTRODUCTION}

A specific, yet familiar scene took place at the 11 th Annual Feminist Theory Workshop held at Duke University in March 2017. In her keynote titled Down with Love: Feminist Critique and the New Ideologies of Work, Kathi Weeks elaborated on the ways in which love has become the mechanism - a new mode of appropriation - that functions to reproduce the figure of the normative worker. Weeks observed the emergence of 'an energetic subject' 1 in

\footnotetext{
${ }^{1}$ Week's talk can be watched at https://www.youtube.com/watch?v=7WOowagkLDE\&t=2483s, last accessed 04.04.2017.
} 
work-life self-help literature, who was capable of self-regulation, understood as a form of intimate investment in work. In the Q\&A session that followed, Weeks' conception of the relation between work and love, as well as of the passionate working subject, were contested for their universalising tendencies. The commentator noted that employers in factories in New Delhi or in Beijing perhaps did not feel the urgency or need to 'construct an ideology'2 of love for work and queried whether there was an implicit elision of the socio-economic differences in Week's theorisation. Week quickly acknowledged the limitation, because of the specificity, of her own argument by clarifying that she looked only within the US context. And she added, "Obviously, I think this is originally targeted to high wage employees."

I recall this scene here not only because of the association of love and critique in feminist theorisations, most tellingly expressed in Sara Ahmed's now well-known assertion 'critique is a labour of love' (2008: 30) as well as in Chela Sandova's theorisation of the methodology of the oppressed as 'a hermeneutics of love (2000: 10.1). But also because it exemplifies a modality of critique where the revelation and insertion of specificities and differences functions as a corrective against generalising gestures. For example, in the dialogue briefly sketched above, the generalisation of the immaterial and affective labour is contested on the basis of the intersectional differences that evoke different relations between love and work. The importance of such a critique is indisputable. And yet, in my opinion, the logic of presence and absence, inclusion and exclusion that such a critique rehearses renders it predictable, and limits the more radical purchase of the problematics of essence and difference. In many cases, a recognition of differences, or an acknowledgement of the blind spot, or limitation, of the theorisation practices, are delivered in response to these critiques. These reflexive gestures then come to stand in as the critical, ethical and political endeavours of feminism. However, two problems arise here. First, the issue of essentialism that undergirds the logic of presence and absence is reinstalled in this assertion of differences. Second, given that partiality is inevitable, the who and what of feminist project presents as a virtual impasse. As Linda Zerilli observes, since a total (feminist) theory cannot exist, we are led to abandon the theoretical enterprise if not the feminist project itself (2005: 36).

This article concerns these conundrums in feminist critical practices. More specifically, it makes visible and engages with various manifestations of oppositional logic in and as, to quote the title of this special issue, 'the epistemic habits of academic feminism'. Rather than repeating the logic of presence and absence, inclusion and exclusion, it zooms in on questions of origin, essence and difference in feminist epistemologies. It proceeds in the following way. First, I provide an overview of some of the key issues in feminist epistemologies, putting emphasis on Donna Haraway's reconfiguration of objectivity. Second, I turn to two lines of critiques against feminist epistemologies. The first account advocates a more radical dismantling of and delinking from the knowledge economy of modernity/coloniality that feminist epistemologies are said to remain embedded in. The second account argues that the difficulties the feminist political project faces reside in the confusion of the political with the epistemological, that is grounded in the deliberative model of rationalism (see Zerilli 2016). Finally, I reconsider the epistemic habits of academic feminism through the figure of zero, that speaks (of) the question of origin and difference. I am aware that these are quite different theoretical frameworks and methodological approaches and that the limited space of this article cannot possibly provide thorough engagements with each paradigm. My aim here, however, is not to provide a comprehensive review of all the theorists' work mentioned here. Rather, it concerns the how of oppositional logical of critique, which as I will show, is key to reconsider feminist epistemologies.

\section{FEMINIST EPISTEMOLOGIES}

The opening scene described above captures the problematics of universality and specificity, or identity and difference, which have been key issues in theorisations of feminist epistemologies. As Claire Colebrook (2017: $448)^{3}$ points out, 'feminism is always the question of who: who speaks, for whom, and whose subjectivity is presupposed in the grammar of the question?' Moreover, the scrutinisation of the universal subject goes hand in hand with feminist contestation of claims of objective knowledge through insisting on asking how we know what we know. Given the emphasis on specificity and difference, it should not be surprising that the term 'feminist epistemology' is often conceived of as an uneasy alliance, if not an 'oxymoron' (Alcoff and Potter 1993: 1).

In their introduction to the anthology Feminist Epistemologies published in 1993, Linda Alcoff and Elizabeth Potter note that feminists' engagements with epistemology have confounded its frame of reference. Typically, traditional epistemology concerns universal and objective knowledge, that is 'knowledge in general'. Its central premises can be summarised in following aspects that concern the subject and the object of the knowledge production process, as well as their relations. First, the subject is understood as unitary, coherent, disembodied,

${ }^{2}$ The Q\&A session is also included in the video linked above.

${ }^{3}$ This is the location number provided in the kindle edition of the book. 
and is capable of simultaneously seeing from nowhere and everywhere. On this account, knowledge, such as theory, is understood to provide a universal account that can be applied to, but is not itself informed by contextual specificities. Second, the object is conceived of as self-present and passive. It provides the fixed ground and raw material/resource for the investigative endeavours of the subject. In other words, to produce knowledge about an object is to re-present and reveal its essence and truth. Third, the subject and the object are separated spatially and temporally. The object is understood as located before, beneath and outside the subject, who codes, deciphers and interprets the world.

This spatio-temporal separation is central to the notion of objective knowledge as a faithful translation of truth. It is informed by and reproduces hierarchical oppositions between culture and nature, mind and body. Such a hierarchisation is also manifested in the subordination of women's everyday 'skilled activity', that is, 'knowing how', to the supposedly proper paradigm of knowledge, that is 'knowing that' (Alcoff and Potter 1993: 11). For example, Vrinda Dalmiya and Linda Alcoff make observations of some of the major factors that were used to justify the denigration and subordination of 'traditional women's beliefs', such as those 'about childbearing and rearing, herbal medicines, the secrets of good cooking', as 'old wives' tales' (1993: 217). As Dalmiya and Alcoff note in the case of midwifery:

midwives often gained their knowledge from their own embodied experience of childbirth ... [which] was empathic, and much of their skill in assisting in childbirth was based on their ability to identify with the expectant mother. This empathy was produced partly by a subjective or first-person knowledge of what it is like (for example) to be a woman going through labor, whereas the knowledge of physicians was grounded in a self-conscious quest for 'objectivity' (1993: 225).

For Dalmiya and Alcoff, the term 'feminist epistemologies' underscores embodied and experiential knowledge production and accommodates a more inclusive framework of epistemology that accounts for objective, intersubjective and subjective modalities. Moreover, it criticises the routine exclusion of women from the subject position of epistemology, because of how women historically have been reduced to the body and thus seen as closer to nature (see for example Pateman and Grosz 1986). Instead of simply including women's experiences into the scene of knowledge production, feminist epistemologies reveal and challenge the political economy of knowledge production, as well as the undergirding violence and moral injunction of the categorical separation of nature and culture (see for example Haraway 2000; Kirby 2011). In so doing, feminist epistemologies call into question the 'nature of knowledge itself', and problematise notions of 'epistemic agency, justification, objectivity', through underscoring 'the impact of the social status as well as the sexed body of the knower upon the production of knowledge' (Alcoff and Potter 1993: 1-2).

A couple of interrelated interventions have been made by feminist scholars working with the question of epistemology: for example, instead of the transcendent and infinite vision, perception and conception are understood as always already mediated by and reproduced by hierarchical relations of power within a specific social context. Moreover, in place of the doctrine of non-contradiction and universal truth, notions of contingency and arbitrariness become central for feminist theoretical and political endeavours. For example, in Bodies that Matter, Judith Butler argues that feminist coalitional politics needs to rework the

logic of non-contradiction by which one identification is always and only purchased at the expense of another (...) in order not to replicate at the level of identity politics the very exclusionary moves that initiated the turn to specific identities in the first place (1993: 118).

Nevertheless, the conception of epistemology as located and multiple, also introduces new problems for the subject of woman. This is because the opposition between specificity and universality, that enables feminist scholars to inquire into the naturalising and disembodied claims of objective knowledge, necessarily entails the impossibility of a single referent of woman ${ }^{4}$. As Donna Haraway points out, the deconstruction of epistemology has also meant that 'no insider's perspective is privileged, because all drawings of inside-outside boundaries in knowledge are theorized as power moves, not moves toward truth' (1998: 576). Given this insight, how might the

\footnotetext{
4 The question of the difference among women and within woman (see Braidotti 1994) has been extensively discussed in feminist scholarly work. For example, as Chandra T. Mohanty writes, “The relationship between 'Woman' (a cultural and ideological composite other constructed through diverse representational discourses - scientific, literary, juridical, linguistic, cinematic, etc.) and 'women' (real, material subjects of their collective histories) is one of the central questions the practice of feminist scholarship seeks to address. This connection between women as historical subjects and the representation of Woman produced by hegemonic discourses is not a relation of direct identity or a relation of correspondence or simple implication. It is an arbitrary relation set up by particular cultures" (2003: 19). Braidotti's nomadic subject and Haraway's cyborg are important efforts.
} 
knowledge claims of women and marginalised others be accounted for without discounting their validity? And how might we account for the differences among women's experiences without prioritizing any perspective?

These questions have posed tremendous challenges to feminist theoretical and political projects. To put the problem in general terms, whose experiences and which identities provide the ground and justification for feminist political alliances? This should also be contexualised in 'the surfacing of 'difference' as the second critical phase in feminist thinking in the late 1979s and 1980s. Griffin's and Bradiotti's observations prove instructive here:

The move in feminism from notions of universal sisterhood and equality of oppressedness within patriarchy, to an understanding of the role that differences among women play in the formation and maintenance of power structures and inequality that affect women differentially, was inter alia spearheaded by black American feminists. (...) Once difference became established as the key concept through which privileged signifier might be critiqued, that concept became transportable into other terrains in which difference had been utilized in the service of oppression and exclusion (2002: 221).

Sandra Harding's conceptualisation of strong objectivity and standpoint theory is an important attempt to navigate through the problematic of identity and difference. This account seeks to take into consideration the intersectional dimension of the subject position, while justifying the need to ground in women's experiences. As Harding makes clear,

standpoint theories of knowledge, whether they are articulated as such, have been advanced by thinkers concerned not only with gender and class hierarchy ... but also with other 'Others'. To make sense of any actual women's life or and gender relations in any culture, analyses must begin in real, historic women's lives, and these will be women of particular races, classes, cultures and sexualities (1991: 151).

And yet, how to see from below remains problematic. In her seminal essay Situated Knowledges: The Science Question in Feminism and The Privilege of Partial Perspective, Donna Haraway voices her misgivings about standpoint theory. Haraway's concern is that standpoint theory's postulation of the innocent vantage point of the subjugated reinstalls a notion of self-same subject whose location is permanently fixed, and whose vision is unmediated by the semiotic technologies of seeing. In concert with Butler's ${ }^{5}$ conception of the epistemic confinement that also characterises the human condition, Haraway argues against narratives of the 'once-upon-a-time wholeness before language, before writing, before Man' (2004: 33) ${ }^{6}$. For Haraway, the various constructions of the primordial coherence of the subject inadvertently recuperates the spatio-temporal gap between nature and culture that underpins the subject/object, mind/matter hierarchies in the first place. In light of this, the problem arises as to how to simultaneously acknowledge the 'historical contingency for all knowledge claims and knowing subjects' without reducing fact or reality simply to rhetoric or form, and 'a no-nonsense commitment to faithful accounts of a 'real' world' (Haraway 1998: 579).

For Haraway, this tension cannot, and in fact, should not be resolved. Instead, the problematic of objectivity and specificity, and the relation between subject and object, could be reconfigured in rethinking the how of knowledge production and the how of vision. As Haraway notes, ' $[\mathrm{v}]$ ision is always a question of the power to see - and perhaps of the violence implicit in our visualizing practices' (1998: 585). If mediation, violence, and corruption are inherent in and integral to any visualising as knowledge production practices, vaguely defined as the process of making the world intelligible, then the strict opposition and separation between the privileged and the subjugated is untenable. Far from 'innocent', understood as unmediated, the subjugated subject position is enabled

\footnotetext{
5 The affinity between Haraway's and Butler's approach is made clear in a footnote where Haraway comments on her understanding of the question of materiality. Haraways writes, "I am using 'matter' in the way suggested by Judith Butler in her work in progress, Bodies [T] hat Matter. ... The marked bodies and subjects theorized by Trinh, Butler, and Wittig evacuate precisely the heterosexist and racist idealism-materialism binary that has ruled in the generic Western philosophical tradition" (Haraway 2004: 61).

${ }^{6}$ In Beyond Identity Politics: Feminism, Power and Politics, Moya Lloyd also comments on Haraway's critique of standpoint theory. The difference between mine and Lloyd's reading lies in the relation between ontology and epistemology in Haraways' theorisations. For Lloyd, Haraway's concern is that in turning towards 'full' and total position', feminist standpoint theory is giving priority to ontology over epistemology. In my reading, Haraway's natureculture approach also effectively rethinks the received gap between ontology and epistemology. In other words, when Haraway writes that '[s] ubjugation is not grounds for ontology; it might be a visual clue' (1998: 586), she is arguing against a particular notion of ontology that functions to, for example, essentialise the 'Third World Woman' (1998: 586). In How Like a Leaf: An Interview with Donna Haraway, Haraway clarifies her stance towards the question of epistemology and ontology. She writes, "One of the things poststructuralism did was to problematize the separation of ontology and epistemology as discourses and I inherit that breakdown" (2000: 78). In my opinion, Haraway is not so much against the prioritising of ontology in feminist standpoint theory as she is concerned with the reinstalled separation between ontology and epistemology in the idea of uncorrupted or unmediated pre-symbolic nature.
} 
by, and participates in, the same field of vision that is informed by particular configurations of relations of power. What Haraway is effectively arguing for here is a notion of complicity ${ }^{7}$, where the subject and the object are implicated in each other. Instead of a mere passive and inert ground before and outside the subject, that awaits inscription, the object - body, nature, Other - is engendered by and engenders the knowing subject as well as the practices of knowledge production. It follows then that objectivity is not abandoned, but rethought as bodily production that is always partial. Such a formulation of objectivity affords Haraway the possibility of accounting for the knowledge claims and experiences of marginalised others, all the while eschewing universalism.

\section{THE PROBLEM OF EPISTEMOLOGY}

Haraway's reworking of epistemology is considered to be in close affinity with third world feminist as well as feminist postcolonial theorisations (see for example Sandoval 2000; Gedalof 1999). For example, for Chela Sandoval, Haraway's cyborg feminism is in line with the 'methodology of the oppressed', for it aims at producing 'a dissident global movement' and rejects any notion of coherent and natural unity or originary wholeness. Nevertheless, as many critics have pointed out, a certain universalising gesture is reinstalled in 'the conflation between women of color as identity, and cyborg feminism as theory' (Sandoval 2000: 170.1). As Sandoval observes,

by gathering up the category 'women of color' and identifying it as 'a cyborg identity, a potent subjectivity synthesized from fusions of outside identities' (i.e., 'Sister Outsider'), her work inadvertently contributes to the elision of differential U.S. third world feminism by turning its approaches, methods, forms, and skills into examples of cyborg feminism (2000: 171.2).

In view of this, the question arises as to whether and how it is possible to develop a feminist theoretical and political project that foregrounds a shared sense of 'we' - that is internally contradictory, as Haraway emphasises - as well as 'our' experiences, without eliding specificities and differences. In this section, I turn to two different critiques against the strands of feminist epistemologies discussed above. First, I draw upon conversation Madina Tlostanova's critique against the coloniality of epistemology (see also Maldonado-Torres 2008). Then I take up Linda Zerilli's suggestion for the separation of the political and the epistemological/philosophical in order to reanimate the political for feminist politics. Despite the differences in their theoretical and methodological approaches, both lines of critiques challenge the residual rationalism in feminist epistemologies and underscore the importance of plurality that is anything but pluralism.

Working within the scholarly field of decolonial feminist theorisations, Madina Tlostanova argues against the 'colonization of knowledge' (2010: 18) which for her limits the critical purchase of feminist epistemologies. For Tlostanova, colonisation of knowledge is a manifestation of the operation of coloniality of epistemology. Tlostanova follows Nelson Maldonado-Torres, who differentiates colonialism from coloniality. As MaldonadoTorres writes,

Coloniality is different from colonialism. Colonialism denotes a political and economic relation in which the sovereignty of a nation or a people rests on the power of another nation, which makes such nation an empire. Coloniality, instead, refers to long-standing patterns of power that emerged as a result of colonialism, but that define culture, labour, intersubjective relations, and knowledge production well beyond the strict limits of colonial administrations (2007: 243).

For Tlostanova, the colonisation of knowledge operates not only in legitimating Western-epistemology as the dominant knowledge system that objectifies the rest of the world, but also in subsuming, appropriating and extracting other knowledge systems for the betterment of Modernity. In view of this, Tlostanova is wary of the logic of opposition or integration that informs some of the most important third world feminist theorisations. In Gender Epistemologies and Eurasian Borderlands, Tlostanova observes these implicit logics in Chandra T. Mohanty's and Jacqui M. Alexander's as well as in Sandoval's theorisations. For example, as Tlostanova argues,

Alexander and Mohanty do not reject the rhetoric of modernity altogether, remaining within its logic though clearly inclining to its socialist pole. Transformation of consciousness and rethinking of identity

\footnotetext{
${ }^{7}$ In Psychic Life of Power: Theories in Subjection, Butler contemplates the question of primary complicity and its political implications. As Butler writes, "The subject might yet be thought as deriving its agency from precisely the power it opposes, as awkward and embarrassing as such a formulation might be, especially for those who believe that complicity and ambivalence could be rooted out once and for all. If the subject is neither fully determined by power nor fully determining of power (but significantly and partially both), the subject exceeds the logic of noncontradiction, is an excrescene of logic, as it were" (1997: 17). While Butler's account of complicity importantly complicates the scene of power's constitution and operation, it nevertheless relies upon an oppositional account of power that I attempt to reconsider here.
} 
are for them the necessary aspects of democracy, seen as a decolonizing practice, while socialism acts as a part of feminist democracy with decolonization at its center. (...) Monhanty and Alexander maintain that feminism must be global and anticolonial, as well as based on socialist principles (2010: 13).

Tlostanova differentiates Mohanty's and Alexander's proposition of 'political decolonization' from what she terms as 'decolonial option' (2010: 11). For Tlostanova, the former's insistence on the socialist principle as the parameter within which transnational feminism is built remains invested in the 'Western modernity's rhetoric of salvation and liberation against the will' (2010: 12). As Tlostanova writes, "there has emerged a number of otherthan-socialist and wider, other-than-modernity models of radical gender resistance in the world. They would not fit the idea of transational feminism if it were based on socialist principles" (2010: 13). In contrast, the decolonial option does not aspire to a universalising or totalising gesture, but insists on 'the pluriversality of contesting projects' (2010: 13).

Whereas Mohanty and Alexander advocate the oppositional positioning of socialist principles against capitalism $^{8}$; Sandoval aims for integration, though not through a unilateral and asymmetrical translation, but 'a double [translation] of the non-Western gender theory into the language of post-modernism and of postmodernist theories into the language of the third world gender discourses' (Tlostanova 2010: 13). Heeding the importance of Sandoval's methodology of the oppressed for 'decolonizing the imagination' (2010: 17), Tlostanova also finds limitation in Sandoval's 'integrative' (2010: 15) framework. For instance, it does not address the operation of the colonisation of knowledge, which is the 'deeper reason' (Tlostanova 2010: 18) for the dismissal of 'the theory and method of oppositional consciousness', that undergirds and connects cross-disciplinary terminologies such as 'hybridity, nomadology, marginalization, Mestiza's consciousness, situated knowledges, strategic essentialism, difference, and schizo-discourse' (2010: 17). For Tlostanova, both the logic of opposition and integration recuperate and run the risk of becoming appropriated by and capitalised upon by the knowledge economy of Western epistemology. This is because binary oppositions are what enable the legitimation, the negation, assimilation and elision of differences by the One/Sameness - Universal, Modern, and Western Epistemology in the first place.

In view of this, Tlostanova proposes the decolonial option that can destabilise the 'extractivist logic of the knowledge economy' (Green 2014) more profoundly. Rather than the totalising and monotopic hermeneutics of the Western epistemology, decolonial thinking proposes 'pluritopic hermeneutics' (Tlostanova 2010: 40), 'border thinking' and 'epistemic delinking' (ibid.: 26). Without going into detailed description of each concept, it suffices to note here that they all underscore a conception of difference that resists being reduced to and elided by sameness. For example, the co-existing and non-hierarchical knowledges are not positioned in the spatial relations of inside and its outside (or the outside of the inside), but on the borders and 'cracks' (Tlostanova 2010: 45) that are 'fragmented' and 'constantly changing' (2010: 44 -45). It follows then that the decolonial option of epistemic delinking also challenges the received notion of inclusion, which continues to be inscribed in the predominant knowledge economy of coloniality/progress/modernity. As Tlostanova makes explicit, 'epistemic delinking, lead[s] to decolonial epistemic shift and bring $[\mathrm{s}]$ forward other principles of knowledge and understanding, an other economy, an other politics and an other ethics' (2010: 26).

Rather than improving or repairing the epistemic system from within through forms of integration and inclusion, or constructing a better or more comprehensive knowledge system, Tlostanova's conceptualisation of the decolonial option attempts to undo the fundamental logic of knowledge embedded in the coloniality/modernity matrix. That is, instead of one system, the decolonial option insists on departing from and being the borders between 'colonial and imperial differences, which were assigned by the dominant discourses to all other people classified as inferior and epistemically disregarded' (Tlostanova 2010: 26). In a similar vein as Haraway's reconsideration of knowledge as fact and fiction, decolonial epistemes challenge the conception of knowledge as objective rationality in their turn to 'folklore, traditional cosmology, religion, nonrational knowledges' (Tlostanova 2010: 26).

Nevertheless, a tension arises in the description of the global project of decolonial practices. For example, in contrast to the universalist and territorial operation of Western epistemic system, decolonial option is understood as a continuous process of differentiation and dis-location that has global reach. As Tlostanova writes,

[d]ecolonial option consciously attempts to get rid of its own possible epistemic provincialism as it opens to more and more locals and contesting epistemic stances along with the original South American basis $\ldots$ beyond $\ldots$ their paradigmatic idea of race, in the direction of intersecting ethnicity, class, and religion (2010: 25-26).

\footnotetext{
8 As Tlostanova explains, "Mohanty and Alexander see capitalism as a set of practices and processes mediated by simultaneous functioning of gender, sexual and racial hierarchies" (2010: 11).
} 
Curiously, in a supposedly humble gesture of offering itself as an option among others, the 'decolonial program' (Tlostanova 2010: 26) starts to resemble Haraway's cyborg feminism in its attempt to unite and bring into conversation 'the multiplicity of oppressed subjects' (2010: 26).

Despite its attempt to move beyond the oppositional logic of difference understood as A/-A, decolonial option seems to rely upon a few pairs of oppositional terms: territorial/border, monotopic/pluritopic, universal/multiple, oppositional/de-linking, appropriation/interaction, dichotomous/dialogical, hierarchical/co-existential. Furthermore, and related to the question of difference, the borders where decolonial thinking is situated are said to be themselves dislocated and fragmented, that is, differentiated. Importantly, this seems to be consistent with the endeavour to decolonise and denaturalise the essentialist account of differences as fixed and unchangeable, that justifies the inferiority of the other. And yet, the presence or location of the border is predicated upon the categorisations of differences produced by the Western knowledge system, or what Tlostanova calls 'colonial and imperial epistemic differences' (2010: 22).

Tlostanova might justify the fixation of these differences that generate the border in terms of the concept of de-linking. That is, to slightly reiterate the foregoing analysis, the most effective contestation of categorical imposition and suppression is the denouncement of its undergirding modernity/coloniality matrix through displacing the hierarchical and monotopic spatial ordering. Nevertheless, in this framework, the figure of the border, as the 'crack' (Tlostanova 2010: 44), the in-between, appears as an entity of sorts, which sits uneasily with the notion of border as fragmented and fractured as Tlostanova proposes. For example, following María Lugones (see for example 2010), Tlostanova suggests that a feminist coalition 'resides in the cracks' (2010: 44), whose subjectivities are multiple and contradictory, which I wish to note is interestingly akin to Haraway's cyborg feminism. And yet, if the border is always broken open and apart, how and where is coalition formed and located? Where does it begin?

The departure point, the identity of feminist coalition, is for Zerilli, one of the major issues for rethinking the political of feminist politics. Her critique against the problem of epistemology for feminism is that it leads to either political paralysis or prescriptive politics that in fact undoes the political (of politics). Although Zerilli's account broaches the question of democracy that are a bit different from the major concerns here, I find her diagnoses of feminist 'epistemological turn' relevant for the discussions about the problem of epistemology. For this reason, I will only briefly bring into conversation Zerilli's advocation of the separation of the political and the epistemological in feminist projects. The upshot of Zerilli's argument is that feminist politics is conditioned upon contingency (see also Wiegman 2012), rather than the predetermined logic of a universal truth. For example, taking issue with standpoint theory as an example of the ways in which feminist political questions are framed in epistemological terms, Zerilli writes,

[F]eminists have been inclined to think about speaking authoritatively in someone's name as a matter of being able to provide foundations of grounds for such speaking. Thinking about political claims as truth claims, feminists have sought to underwrite their action and speech in ways that would, more or less, be unassailable as better if not correct views of the world (2005: 171).

For Zerilli, the received crisis of feminist political and critical projects resides in the fantasy about 'the wholeness of political origins' (2005: 2) of the category of women, which is coupled with the instrumentalist conception of politics as means-to-an-end practices, that are guided and justified by knowledge claims. That is, for instance, the truth of the different experiences and subject positions of women. Unlike the decolonial option that urges to denounce the extractive knowledge economy of the Eurocentric episteme, Zerilli does not consider epistemology's disposition to generalise as necessarily a problem. As Zerilli asks,

is this desire [of giving an exhaustive account of gender relations] unreasonable? Hasn't second-wave American feminist theory itself incited our desire for solace by generation a long chain of causal explanations of women's oppression which, if rightly understood, could be rightly remedied? (2005: 35).

According to Zerilli, the problem lies in the ways in which political claims are explained in terms of knowledge claims. Following Hannah Arendt (see for example 2005)9 , Zerilli argues that political practices are grounded in

\footnotetext{
${ }^{9}$ It is helpful to note how the notion of contingency is understood and utilised differently in Zerilli's and Haraway's respective work. Whereas Haraway writes about the contingency of knowledge and subject formation, Zerilli equates contingency with freedom. For example, as Zerilli writes, "[s]aving truth requires that we take the risk of freedom, even though freedom (i.e., contingency, not necessity, rules in human affairs) also presents grave risks for truth, which gives rise to a paradox of truth for politics" (2016: 137). Zerilli's conception of contingency as freedom draws on Arendt's work, who conceives of freedom in terms of spontaneity and action. As Arendt writes, " $[t]$ he idea that freedom is identical with beginning or, again to use a Kantian term, with spontaneity, seems strange to us because, according to our tradition of conceptual thought and its categories, freedom is equated with freedom of the will, and we understand freedom of the will to be a choice between givens
} 
contingency rather than identity (that is supposedly the justified knowledge about who we are and about our particular experiences), which anticipates or enacts the political space of plurality. In other words, and in a somewhat similar vein as the border thinking proposed by the decolonial option, plurality is synonymous with contingency, that is, not defined by categorical differences. Zerilli's clarification proves helpful here, and I will cite it at length:

$[P]$ lurality requires that we do something in relation to whatever empirical differences may exist: plurality names not a passive state of ontological difference but an active and ... imaginative relation to others in a public space. Plurality, as a political relation external to its terms, is based in the faculty of presentation (imagination) and not - or not initially - in the faculty of concepts (understanding). I can know empirical differences exist as part of the human condition, yet fail to acknowledge them, for the latter act involves more than cognition or the application of concepts to particulars (or, more precisely, where cognition is involved, acknowledgement requires that I do something on the basis of what I know) (2005: 146; emphasis in original).

Positing plurality, that is contingency, as the condition of possibility of the political, Zerilli shifts attention to inter-subjective relations that are non-epistemological. Although I completely agree with Zerilli on the need to eschew prescriptive politics, I wonder about the implications of the separation of the political and the epistemological, and of praxis and theory. Returning to the opening discussion at this point, I have noted the ways in which feminist interventions into the theorisations of epistemology were guided by the political aim of challenging the masculinist conception of universal, disembodied and objective knowledge. As Haraway's confounding of fact and fiction, as well as her critiques against the god trick make clear, feminist epistemologies are critical interventions into the very foundation of the knowledge system of phallogocentrism. In other words, the terms of reference of what counts as knowledge or as proper mode of knowledge production are rethought. This is also relevant to the ongoing feminist debates about the relation between feminism as a political and activist project and as a set of theoretical practices (see also Wiegman 2012). The situatedness or locatedness insisted upon in various strands of feminist theorisations of epistemology are challenges to the divorce between reason/objective rationality and embodied/material contingencies (see for example Pateman and Grosz 1986).

Given this, I wonder whether non-epistemological feminist politics might run the risk of recuperating these divisions that feminist political and theoretical projects have set out to contest. What Zerilli's assertion inevitably raises is the question of why the universality of knowledge claims is unable to adequately approach the question of difference. As Zerilli writes, in framing political claims in terms of knowledge claims, feminism is presented with an impossible choice. That is, feminism either 'acknowledge[s] differences (and risk a subjectivism that effaces truth) or articulate[s] a wrong (and risk an objectivism that effaces difference)' (Zerilli 2005: 138; emphasis in original). Zerilli's observation here is informed by a certain notion of the oppositional relation between universality and specificity, or universal/object knowledge and particular lived experiences. Rather than reconsidering the nature of these underlying assumptions, Zerilli's critique of feminist epistemologies requires the fixation of these oppositions in order to justify an Arendtian conception of politics. For example, although noting that 'there is much to recommend' in Haraway's rejection of both objectivism and subjectivism, and her proposition of the alternative as objectivitiy that is 'partial, locatable, critical knowledges sustaining the possibility of webs of connections called solidarity in politics and shared conversations in epistemology' (Haraway in Zerilli, 2016: 174), Zerilli does not engage further with Haraway's contestation of the split between the object and the subject, as well as Haraway's attempts to rethink the relation between universality and specificity beyond the logic of opposition.

Moreover, in Zerilli's reading, Haraway's theorisation of partiality is translated into accounting for differences, for 'a (more) critical epistemology' (2016: 174). While I concur with Zerilli that the received equation between truth/justification and critical epistemology need to be rethought through, for example, shifting from a subjectcentered conception of judgement, I understand that an important dimension of Haraway's theorisation of situated knowledge is precisely about redefining subjectivity as non-located, because it is internally split and always already inter-subjective. In Zerilli's account, conception and cognition comes after the originary moment of political action. But it is unclear where inter-subjective validity (which for Zerilli is the basis of political claim) ends and subjective conception begins? What can it mean to posit conception as located squarely within the individual subjective realm? Does this in some ways reinstall the mind/matter division that feminist epistemologies have sought to contest? ${ }^{10}$

or, to put it crudely, between good and evil. We do not see freedom as simply wanting this or that to be changed in some way or other" (2005: 113).

${ }^{10}$ In my reading, Zerilli has been trying to think further these questions in her recent comment on affect theory. For example, she writes, "Affect and cognition are not two different systems but radically entangled. ... Can we describe the radical entanglement of affect and conceptual rationality in a way that keeps their mutual imbrication from sliding into always already affectively primed responses, on the one hand, or always already conceptually determined responses, on the other hand? This is the real problem - the problem of a critical judgement - raised at once by and for affect theory" (2016: 261). 
My point here is not to say that Zerilli misreads Haraway, but to point out the ways in which critiques often begin and end by producing the oppositions and conceptions that they set out to challenge, or that could have been pushed further. In view of this, and given that feminist epistemologies are decisively about location and the departure point of enunciation, I will now turn to the figure of zero.

\section{COUNTING ZERO}

In this article, I have tried to make visible the epistemic habits in the diverse and often contradictory theorisations and critiques of feminist epistemologies, as the ones outlined here. More specifically, I have tried to think further about what relations between universality and plurality are evoked, and how the questions of origin and differences are understood, in feminist critiques of epistemology. I show that despite the different endeavours to eschew the universal tendencies of epistemology, and to provide anti-essentialist accounts of difference, feminist theorisations of and against epistemology often begin and end by producing an oppositional account of difference. Moreover, and interestingly, despite their differences, these accounts are informed by an explicit or implicit disavowal of the notion of origin.

Typically, origin is associated with self-sameness and wholeness, and implies a conception of nature and bodies as fixed and immutable. It has two functions that are particularly relevant for the discussions at hand. First, posited as a homogeneous unity, the origin is conceived of as containing the essence which verifies the objectivity of knowledge and the truth of an identity. Second, and relatedly, informed by notions of progress, the simplicity of origin (nature) provides the point of departure that the evolved complexity (culture) is measured against. Such a configuration provides justification for various sexualised and racialised conceptions of knowledge. For example, as noted earlier, women's knowledge (knowing how) was not regarded as knowledge proper (knowing that), because it is embodied and affective.

It could be said that the rejection of the notion of origin in feminist epistemologies is an important endeavour against essentialising, sexualising and racialising conceptions of knowledge. And yet, and interestingly, this original wholeness is often recuperated in feminist emphasis on differences among women and the contingency of knowledge. For example, as Zerilli observes,

The breathless pace with which members of the earliest second-wave feminist groups split off to found other groups, only to find members of the new group splitting off to found yet other groups, indicates what we might call a retroactive fantasy about the wholeness of political origins (2005: 1-2).

As I have sought to show, the received notion of the causal determination of the originary wholeness is implicitly recuperated in being contested in feminist rethinking of epistemology. For example, in Haraway's assertion of the implicatedness of the subject and the object, as well as the necessary partiality and locatedness of the process of knowledge production, the notion of origin is rejected, for it connotes purity, unity and wholeness, which for Haraway is the Western fantasy that ultimately serves the domination and control of Man. However, this sense of origin is kept alive as it provides the ground against which the multiplicity and partiality of situated knowledge and the cyborgian subjectivities are defined. In a similar vein, the universalist notion of 'the common origin of all human beings' (2010: 22), as well as its concomitant epistemic scheme, are necessitated in Tlostanova's formulation of border thinking as the epistemology of the exterior. In fact, this is made explicit in the Tlostanova's following clarification,

Border thinking is the epistemology of the exteriority that is of the outside created from the inside ... But this is not a simple change of one (Western) epistemology to another or others. All the models continue to exist and remain viable as sources and targets of criticism (2010:26).

How then might it be possible to call into question the received notion of origin as pure and whole that does not reinstall it in its negation? This section zooms in on this problematic. As I will show, a critical rethinking of the notion of origin, and its correlated terms such as nature, essence and whole, is central for reconfiguring feminist habits of critique, and relatedly, feminism as a theoretical and political project. Given that many discussions in feminist theorisations of epistemology center on the difference between the One and the multiple, I approach the question of origin through performing the task of counting zero.

At the beginning of this article I quoted Donna Haraway and Luce Irigaray as they both touch upon the issue of counting, that is how to count, account for, take into account, differences and specificities. Whereas Haraway suggests counting to four, Irigaray points out the impossibility of counting. In what follows I will first elaborate on their different positions vis-à-vis counting. As the quote makes clear, Haraway asks us to consider the possibility of rethinking differences (counting to four) among women, rather than remaining trapped in the logic of Man/Others, A/-A. As Irene Gedalof also comments on the same quote: 
Haraway's arithmetical challenge to feminism - that is learn 'to count for four' - is a call to think about the paradigm shifts that would problematize many of the assumptions about ontology, power and language that much of feminist theory still takes as its starting points (1999: 146).

For Haraway, in order to achieve affinity in politics (rather than grounding politics in an essentialist notion of affinity and identity) and to dismantle the command and control of (Western) knowledge system, it is of utmost importance to entirely abandon the dualistic paradigm that is constituted by and reproduces Sameness. Although mentioned only briefly in her writing, it seems to me that the question of zero is key for understanding the possibilities and impossibilities of counting to four that Haraway proposes. In A Manifesto for Cyborgs, Haraway reveals the production and denigration of Otherness in the dualistic formulation of the subject. As she writes:

Every story that begins with original innocence and privileges the return to wholeness imagines the drama of life to be individuation, separation, the birth of the self, the tragedy of autonomy, the fall into writing, alienation; i.e., war, tempered by imaginary respite in the bosom of the Other. These plots are ruled by a reproductive politics - rebirth without flaw, perfection, abstraction. ... But there is another route to having less at stake in masculine autonomy, a route that does not pass through Woman, Primitive, Zero, the Mirror Stage and its imaginary (2004: 34-35).

The figure zero here relates to Jacques Lacan's theorisation of the process of subject formation. To put simply, in the Oedipal structure, zero is understood as a plenitude that acquires identity and becomes one only in relation to the signifier phallus by the name-of-the-father (see Grosz 1990). This is in fact criticised in both Irigaray's assertion of the impossibility of counting and Haraway's provocation of counting to four. Although it is impossible here to provide a thorough account of Lacan's psychoanalytic account of zero, for my analysis, it is important to understand how it is interpreted and challenged in Haraway's and Irigaray's respective work.

Haraway's argument for another route of becoming that is grounded in the ordinary everyday life for survival rather than 'through Woman, Primitive, Zero, the Mirror Stage and its imaginary' could be read as a critique against the logic of reproduction, which is ultimately about the progressive continuity of One/Man. The movement from zero to one is the process of abstraction and extraction, symptomatic of the Western/Masculine/Colonial system of knowledge production. Retrospectively understood as the 'little' man' (Grosz 1990: 102), zero is not so much a neutral space as it is always already defined through a certain notion of sexual difference and reproduction. Calling into question the received necessity or inevitability of the Oedipal paradigm of the knowing subject - zero becoming one, 'if it does so' (Grosz 1990: 104), Haraway's account of situated knowledge posits the subject as always and simultaneously partial and multiple. That is, it constitutes and is constituted by the object, the bodily apparatus as well as other relations of knowledge production. This seemingly contradictory simultaneity also radically reconfigures what one is. That is, unlike in the Western/Masculine/Colonial system of knowledge where $1+1+1+1=1$, in the formulation of situated knowledge production $1+1+1+1>4$. In my opinion, it is in this sense, that it is possible to begin to count to four. And yet, on this account, zero is simply negated rather than reconfigured.

In contrast, Irigaray finds critical purchase in the ways in which zero functions as the condition of possibility for the operation of the Law of the Father. For Irigaray, zero presents the radical debt for each speaking subject. That is, as the (w)hole, the (m)other, zero presents the unity that is uncalculatable and inaccessible. For Irigaray, the episteme is grounded in the illusion of the one, the individual, so that it can 'count everything, to number everything by units, to inventory everything as individualities' (1985: 26). And yet, zero - the (w)hole, the (m)other - exceeds such a numerical measurement, and 'resists all adequate definition' (Irigaray 1985: 26). She is the outside, 'the negative, the underside' (Irigaray 1985: 26) of the knowledge economy of accumulation, division and appropriation. She is the zero, the nil, the none. "Neither 'one' nor 'two"' (Irigaray 1985: 207). Rejecting an account of difference that remains within the phallogocentric confinement, Irigaray asserts:

We are luminous. Neither one nor two. I've never known how to count. Up to you. In their calculations, we make two. Really, two? Doesn't that make you laugh? An odd sort of two. And yet not one. Especially not one. Let's leave one to them: their oneness, with its prerogatives, its domination, its solipsism: like sun's (1985: 207).

And yet, the zero is still 'counted as none' (Irigaray 1985: 26; emphasis added). Or to recall my reading of Haraway's rejection of zero, it could be said that the received notion of zero as the originary plenitude is always already informed by the Oedipal structure. Irigaray concedes an originary wholeness to zero, which as Vicki Kirby observes, 'precedes the rupture of copula-tion (becomings), as if, in simply terms, it just is' (2011: 131). Given this radical outsideness, it is unclear how this 'pure, isolated' (Kirby 2011: 130) origin comes to be counted as zero, 
which, as I will shortly show, is far from absolute nothing ${ }^{11}$. It seems then that whereas Haraway abandons zero to reconfigure one, Irigaray calls into question the phallogocentric illusion of masculine autonomy by revealing the promise and threat of the radical debt that zero is.

How might this reading of zero assist my concern here about the habits of feminist critique? As my foregoing analysis has hopefully shown, on both accounts, the received notion of zero as originary wholeness is conceded to (in Haraway's theorisation it is installed in being refused). And as I have tried to make explicate, both feminist critiques against traditional epistemologies, and against feminist epistemologies, remain invested in the selfevidence of origin - its wholeness and universality - even in the form of negation. At the risk of providing somewhat of a caricature, it could be said that feminist theoretical and political endeavours often concern the question of identity and difference. That is how the specificities might be taken into account and accounted for, all the while building alliances and coalitions. Notwithstanding the different turns in feminist scholarly field, the relation between the One and the multiple continues to inform feminist debates, and is often conceived of as an inevitable impasse.

Given this, in what follows I provide a preliminary account of counting zero. My point is not to suggest that such a rethinking provides the corrective of or the solution to the received tensions in feminist debates. Instead, I argue that if zero as origin is never simply homogenised and unified, any more than specificities are complex and multiple, then the various forms of critique that ground in their opposition also need to be rethought.

So what does it mean to count zero? The difficulty of this question resides in the puzzles of thinking about zero. First, zero is a meta-number. That is, it 'stands for the absence of number, any number' (Miller 2003: 47). In this case, it could also be used as a placeholder for any particular number. For example, consider the number 2017 and 2107. Whereas in the former zero stands for 100, in the latter it stands for 10. Second, zero is the container of all numbers. That is, it generates infinite numbers. Third, to complicate the matter even further, the signification of zero as the origin of all numbers and/or the absence of any number, is conditioned upon the preposition 'of'. In other words, zero cannot be understood separately from the number that it generates or lacks.

What I am getting at is a sense of radical implicatedness that also makes visible the ways in which zero, as origin, is never simply whole, any more than it is absolutely lacking. Interestingly then, zero seems to be simultaneously whole and part, universal and specific, nothing and everything. In view of this, might it be possible to entertain the possibility of not simply conceding to the presence of origin, or rejecting it because it seems that 'when we search for an origin we inevitably discover contemporary preconceptions and desires in the nature of its identity' (Kirby 2011: 142)? In other words, if zero implicates and is implicated in its multiple and contradictory manifestations, then it could also be said, that the terms of reference of opposites, such as universality and particularity, can be affirmed, refused and reconfigured. It follows then that critique is a labour of love, not because it is opposite to opposition, but because the radical implicatedness of which zero is an expression of, means that contradiction and opposition are internal to love's operation.

In this article, I have sought to make visible the ways in which oppositional logic operates as a habit of critique in feminist reconfigurations of epistemology. I have shown that despite their differences in terms of theoretical frameworks and methodological approaches, one of the shared political and ethical commitment of feminist (critiques of) epistemologies is to contest forms of transcendence (for example the conception of epistemology as disembodied objective knowledge) and the exclusion and marginalisation of otherness. And yet, the difficulty remains as to how see from the vantage point of others without reproducing essentialist notion of identity. In their attempt to eschew fixation, feminist critics seek to ground knowledge production and politics in the contingency of Otherness. On these accounts, questions of origin, whole and universality are routinely disavowed as illusions that are engendered by and engender the coloniality of knowledge centered on the figure of Man coded as white and masculine. Nevertheless, as the critiques of Haraway's cyborg feminism and my reading of Tlostanova's conception of pluritopic hermeneutics have hopefully shown, the political and ethical commitment to specificities cannot easily do away with forms of abstraction, extraction and opposition. Moreover, and relatedly, in positing the others as equally outside and below the hegemonic order, their differences, variations and contradictions are sidelined.

Does feminist commitment to specificities necessarily lead to prescriptive politics that compulsively reproduces, in the hope of including, differences rather than attending to 'differences that matter' (Ahmed 1998)? Is the received tension between universality and specificity inevitable and irreconcilable? And is severing the political from the epistemological the only viable option? My preliminary account of zero is an attempt to reconsider these conundrums and the oppositional logic that informs feminist habit of critique. Although the theorisations discussed here all underscore complicity, and contest oppositional account of critique, they rely upon forms of distance from notions of origin and whole in the first and last instance. Interestingly, notwithstanding their vehement challenges to fixation and essence, the nature of origin and whole is not itself in question. In counting

11 As Robert Kaplan writes, zero 'is a nothing that is an actual something’ (2000: 14).

(C) 2017 by Author/s 
zero, I argue that the identity of zero, origin and whole is not self-present, but implicates and is implicated in specific manifestations, differently. Rather than producing oppositions of opposition, or critiques of critique (see for example Felski 2015), I suggest that counting zero affords a modality of critique that activates the political of feminist politics understood as simultaneously located, specific, contradictory and original.

\section{REFERENCES}

Ahmed, S. (1998). Differences That Matter: Feminist Theory and Postmodernism. Cambridge: Cambridge University Press.

Ahmed, S. (2008). Open Forum Imaginary Prohibitions: Some Preliminary Remarks on the Founding Gestures of the 'New Materialism'. European Journal of Women's Studies. 15(1), pp. 23-39.

Alcoff, L. and Potter, E. (1993). Introduction: When Feminisms Intersect Epistemology. In: L. Alcoff and E. Potter, eds., Feminist Epistemologies (pp. 1-14). New York and London: Routledge.

Arendt, H. (2005). The Promise of Politics, edited and with an introduction by Jerome Kohn. New York: Schocken Books.

Braidotti, R. (1994). Nomadic Subject: Embodiment and Sexual Difference in Contemporary Feminist Theory. New York: Columbia University Press.

Butler, J. (1993). Bodies that Matter: On the Discursive Limits of "Sex". New York and London: Routledge.

Butler, J. (1997). Psychic Life of Power: Theories in Subjection. Stanford: Stanford University Press.

Colebrook, C. (2017). We Have Always Been Post-Anthropocene: The Anthropocene Counterfactual. In: R. Grusin, ed., Anthropocene Feminism (kindle version). Minnepolis and London: University of Minnesota Press.

Dalmiya, V. and Alcoff, L. (1993). Are “Old Wives' Tales" Justified?. In: L. Alcoff and E. Potter, eds., Feminist Epistemologies (pp. 217-244). New York and London: Routledge.

Derrida, J. (1978). Writing and Difference. Chicago and London: The University of Chicago Press.

Derrida, J. (1998). Monolingualism of the Other; or, The Prosthesis of Origin. Stanford: Stanford University Press.

Gedalof, I. (1999). Against Purity: Rethinking Identity with Indian and Western Feminisms. London and New York: Routledge.

Green, L. (2014). Ecology, Race, and the Making of Environmental Publics: A Dialogue with Silent Spring in South Africa. Resilience: A Journal of the Environmental Humanities, 1(2). https:/ / doi.org/10.5250/resilience.1.2.002

Griffin, G. and Braidotti, R. (2002). Whiteness and European Situatedness. In: G. Griffin and R. Braidotti, eds., Thinking Differently: A Reader in European Women's Studies (pp. 221-236). London and New York: Zed Books.

Grosz, E. (1990). Jacques Lacan: A Feminist Introduction. London and New York: Routledge.

Felski, R. (2015). The Limites of Critique. Chicago and London: The University of Chicago Press.

Haraway, D. (1991). Simians, Cyborgs and Women: The Reinvention of Nature. London: Free Association Books.

Haraway, D. (1998). Situated Knowledges: The Science Question in Feminism and the Privilege of Partial Perspective. Feminist Studies, 14(3), pp. 575-599.

Haraway, D. (2000). How Like a Leaf: An Interview with Thyrza Nichols. New York and Oxon: Routledge.

Haraway, D. (2004). The Haraway Reader. New York and London: Routledge.

Harding, S. (1991). Whose Science? Whose Knowledge?: Thinking from Women's Lives. New York: Cornell University Press. Irigaray, L. (1985). This Sex Which Is Not One. Ithaca: Cornell University Press.

Kaplan, R. (2000). The Nothing that Is: A Natural History of Zero. Oxford: Oxford University Press.

Kirby, V. (1997). Telling Flesh: The Substance of the Corporeal. New York and London: Routledge.

Kirby, V. (2011). Quantum Anthropologies: Life at Large. Durham and London: Duke University Press.

Lloyd, M. (2005). Beyond Identity Politics: Feminism, Power \& Politics. London, Thousand Oaks and New Delhi: Sage.

Lugones, M. (2010). Toward a Decolonial Feminism. Hypatia, 25(4), pp. 742-759.

Maldonado-Torres, N. (2007). On the Coloniality of Being. Cultural Studies, 21(2), pp. 240-270.

Maldonado-Torres, N. (2008). Against War: Views from the Underside of Modernity. Durham and London: Duke University Press.

Miller, H.J. (2003). Zero Plus One. Valencia: University de Valencia.

Mohanty, C.T. (2003). Feminism without Borders: Decolonizing Theory, Practicing Solidarity. Durham and London: Duke University Press.

Pateman, C. and Grosz, E. (1986). Feminist Challenges: Social and Political Theory. Sydney: Allen \&Unwin Australia.

Sandoval, C. (2000). Methodology of the Oppressed. Minnepolis and London: University of Minnesota Press.

Tlostanova, M. (2010). Gender Epistemologies and Eurasian Borderlands. New York: Palgrave Macmillan.

Wiegman, R. (2012). Object Lessons. Durham and London: Duke University Press.

Zerilli, L.M.G. (2005). Feminism and the Abyss of Freedom. Chicago and London: The University of Chicago Press.

Zerilli, L.M.G. (2016). A Democratic Theory of Judgement. Chicago and London: The University of Chicago Press. 
Citation: Liu, X. (2017). Counting Zero: Rethinking Feminist Epistemologies. Feminist Encounters: A Journal of Critical Studies in Culture and Politics, 1(1), 07. https://doi.org/10.20897/femenc.201707

Copyright (C) 2017 by Author/s and Licensed by Lectito BV, Netherlands. This is an open access article distributed under the Creative Commons Attribution License which permits unrestricted use, distribution, and reproduction in any medium, provided the original work is properly cited. 
http://www.lectitopublishing.nl

https://www.facebook.com/LectitoJournals/

https://twitter.com/lectitojournals

$\mathcal{S}_{+}$https://plus.google.com/110901545130385419486

in https://www.linkedin.com/in/lectito-journals9a675010b/ 


\title{
Music Videos as Black Feminist Thought - From Nicki Minaj's Anaconda to Beyoncé's Formation
}

\author{
Katariina Kyrölä ${ }^{1 *}$
}

Published: October 30, 2017

\begin{abstract}
The article examines two recent music videos by Black female artists, Nicki Minaj's Anaconda (2014) and Beyoncé's Formation (2016), and the heated online discussions around them about whether they are feminist or not. The article argues that the epistemic habit of asking this question often works counterproductively and stabilises the boundaries of feminism. Instead, the two music videos are considered as creative works of Black feminist thought, following Patricia Hill Collins (2009). Collins suggests that in order to challenge traditional forms of white male knowledge production, other forms of expression than academic writing should also be considered theory. The key question then becomes: how do Anaconda and Formation participate in, re-imagine and work as Black feminist thought, understood as complex and dynamic? The article outlines three main critiques directed at the videos: selling out to white people and capitalism; promotion of white, heteronormative body ideals while appropriating queer of color culture; and involvement in so-called 'reverse oppression'. Anaconda and Formation can be seen to answer each these critiques respectively, when seen connected to and employing strategies of Black feminist theories of pleasure, queer of color critique, and Black feminist politics of coalition among marginalised subjects.
\end{abstract}

Keywords: feminist epistemology, Black feminist thought, queer of color critique, music videos, sexuality

\section{INTRODUCTION}

In the mid-2010s, two music videos by two Black American female artists, singer and actress Beyoncé (Beyoncé Giselle Knowles-Carter, b. 1981) and rapper and hip-hop artist Nicki Minaj (Onika Tanya Maraj, b. 1982), became targets of keen debate and controversy, quickly emerging as popular cultural boiling points for questions of race, gender and sexuality. These two music videos were Nicki Minaj's Anaconda, released August 4, 2014 (directed by Colin Tilley) and Beyoncés Formation, released February 6, 2016 (directed by Melina Matsoukas).

Both music videos went viral immediately after their release, and within days, online commentaries filled with heated arguments against and for the kinds of Black feminisms the videos were seen to represent started pouring in. The sexually explicit, campy Anaconda rap music video received over 19 million views on YouTube within 24 hours of its release, ${ }^{1}$ and in April 2017 the number of views had exceeded a staggering 672 million. ${ }^{2}$ Also by April 2017, the directly political and aesthetically stunning Formation had received about 92 million views on YouTube. ${ }^{3}$ The online buzz around Formation was further incited by Beyoncés performance of the song during the halftime show of the Super Bowl (the annual championship game of the US National Football League, NFL) one day after the release of the song. In the performance Beyoncé was accompanied by a group of Black female dancers dressed in black leather costumes and black berets, paying tribute to the Black Panthers and Michael Jackson. The Anaconda

\footnotetext{
${ }^{1}$ Wikipedia: Anaconda (Nicki Minaj song).

2 NickiMinajAtVEVO (2014).

3 This number is a combination of view on Beyoncé's VEVO YouTube channel where the Formation video has existed since December 2016, and Beyoncé's own official YouTube channel, where it had existed since its release unlisted (beyonceVEVO, 2016; Beyoncé, 2016). 'Unlisted' video means that it does not show up in YouTube or Google searches, unless you have the link. After its release, Formation was mostly marketed through Tidal, a paid subscriptionbased video and music streaming service, as a free download which nevertheless required subscription to the service. This is why, at first, Formation seemed relatively difficult to see legally.
} 
video, on the other hand, quickly provoked a plethora of remixes, parodies, and reaction videos by social media users. ${ }^{4}$

While the Anaconda and Formation music videos are very different musically and visually, in tone, style, lyrics and aesthetics, they both elicited thousands of analyses and online debate pieces which, although written from various perspectives, focused largely on the same question: are these music videos and the artists behind them feminist or not? Also academic analyses on Beyoncé and Nicki Minaj's celebrity personas and musical production have often asked this very same question. It seems that the 'feminist or not' question has become an epistemic habit in feminist writing, and one that raises important concerns over what the aims of feminist cultural critique and production are at large. I argue that the very gesture of this question can inadvertently turn into guarding the boundaries of what feminism 'is', and policing who is a good feminist and who is not - thereby fixing the object 'feminism', instead of exploring and constantly recreating what feminist strategies of critique and empowerment might mean, feel, and look like. Moreover the question easily obscures the complexities of Black feminisms which Formation and Anaconda draw on and participate in.

In this article, rather than ask the question 'feminist or not' and offer yet another answer, I will simply start from the acknowledgement that Formation and Anaconda are creative works of Black feminist thought in the sense suggested by Black feminist theorist Patricia Hill Collins (2009), even though and especially because they are not forms of expression that the white-dominated academia has traditionally considered thought or theory. Instead, I ask: what kind of strategies and understandings of empowerment do Anaconda and Formation suggest for the marginalised? What kind of critiques do they offer, continue and develop as Black feminist thought? While exploring these questions, I try to avoid homogeneous understandings of feminism as well as Black feminism which the 'feminist or not' question easily leads to. Furthermore, I want to consider the politics of engaging in a dialogue with the two music videos and Black feminist analyses of them as a white feminist scholar.

The music video and the song Anaconda, a parodic partial sample of Black American rapper Sir Mix-a-Lot's popular song Baby Got Back (1992), may not immediately connote 'feminist' to many viewers - at least not to a white feminist viewer like myself, not well versed (at the time of first viewing) in the types of Black feminist epistemologies it connects to, such as hip-hop feminism (e.g. Morgan 1999; Durham et al. 2013). In the racy and campy music video, Minaj and her Black and white female dancers writhe, twerk, slap and caress each other in scanty clothing in a stylised jungle setting. The video also includes scenes where Minaj lifts ridiculously tiny pink weights in pink sweatpants, and plays with whipped cream and bananas in a jungle kitchen. The video ends in a much-debated scene where Minaj gives a lap dance to rapper Drake and finally slaps away his hand and walks away.

In comparison, while Formation also includes sexually straightforward lyrics and dance, its humour is more subtle, and it includes direct commentary on racism in the South and critique of the killings of Black people by the police force in the US. The video, set in Louisiana and New Orleans, combines scenes of Black women and girls sitting and dancing in traditionally white Southern antebellum settings; scenes of houses and police cars sinking into floodwater, reminding of Hurricane Katrina; dance scenes shot as if through surveillance cameras; a little black boy raising his hands in front of white police officers; scenes drawing on voodoo, Mardi Gras and Southern queer of color culture, featuring vocals by Black queer artists in the New Orleans area, Big Freedia (b. 1978) and Messy Mya (1987-2010). Subsequently, Beyoncé released the visual album Lemonade on 23 April 2016, part of which is Formation.

Through a process of sampling online commentary and criticism on Anaconda and Formation from summer 2014 to spring 2016, I found three intertwined main lines of critique, or contexts in which the question 'feminist or not' has been asked and answered negatively. These are: 1) the claim that Nicki Minaj and Beyoncé have sold out to white people and capitalism, and thus lost their empowering potential; 2) that they promote harmful, white and heteronormative body and beauty ideals while appropriating queer of color culture; and 3) that they promote forms of so-called 'reverse oppression'. More specifically, Anaconda has been criticised for 'skinny shaming', as it celebrates the big Black butt while telling 'skinny bitches' to 'fuck off' (Veiga 2014), and Formation has been criticised for 'racism against white people' (Bitter Gertrude 2016). The critique geared at 'reverse oppression' has, unsurprisingly, originated from white audiences, and the 'skinny shaming' critique came from some white feminists, while the critiques concerned about selling out to white capitalism and promoting white heteronormative body and gender ideals came from Black feminist thinkers and writers. While interrogating these three lines of critique and the feminist (or anti-feminist) publics that have posed them, I will also discuss ways in which the two music videos can be seen to respond to, or even predict and pre-empt, such critiques, when located in and seen through brands of Black feminist thought/theory and queer of color critique.

\footnotetext{
4 For example, Anaconda - the Educational Version (Nicki Minaj Parody) by CollegeHumour at https://www.youtube.com/watch?v=6VxV717PRBU (accessed 16 April 2017), about what kind of snake the anaconda is; Ellen DeGeneres' Ellen's Anaconda Video at https://www.youtube.com/watch?v=cqp0km5VRj4 (accessed 16 April 2017), where Ellen DeGeneres has edited herself into the original video; and Elders React to Nicki Minaj - Anaconda at https:/ / www.youtube.com/watch?v=zx-WoMdBfV8 (accessed 16 April 2017).
} 


\section{LOCATING BEYONCÉ AND NICKI MINAJ IN/AS BLACK FEMINIST THOUGHT AND QUEER OF COLOR CRITIQUE}

In her book Black Feminist Thought (2009, originally 1990) Black feminist scholar Patricia Hill Collins makes a passionate plea that in order to change the ways in which knowledge and theory uphold racialised and gendered power relations, we must broaden our ideas of what counts as critical social theory and feminist thought, and what counts as valuable knowledge. Black women's voices have been silenced for so long in the traditions of the academia, and other white dominated social and cultural institutions - including white feminisms - that they have had to seek other outlets to become heard and visible in their own terms. Following Collins in her claim that "[a]nalyzing and creating imaginative responses to injustice characterize[s] the core of Black feminist thought" (2009, 15), Nicki Minaj's Anaconda and Beyoncé's Formation music videos should be seen as creative works of Black feminist thought that respond imaginatively to injustices, and indeed command global attention to the complex co-production of race, ethnicity, gender and sexuality.

More specifically, I read both music videos as calls for a politics of coalition, following Black queer feminist thinker Cathy Cohen (1997), across and within multiple differences, suggested already in their visual emphasis on clusters and formations of bodies. However, this politics of coalition is not about horizontal or 'equal' alliance, where all differences would be set on one line, but a politics drawing on Black feminist stand-point epistemologies, beginning from and driven by the situated knowledges of the marginalised, of Black women and queer of color culture. Another key critical framework which I see the two music videos connecting to is queer of color critique (e.g. Ferguson 2004) and in particular José Esteban Muñoz's (1999) writings on disidentification in relation to queer of color performance art. For Muñoz, "disidentification is a survival strategy that works within and outside the dominant public sphere simultaneously" (ibid.: 5). The 'selling out' to white dominant ideology that Beyoncé and Nicki Minaj have both been accused of could perhaps be considered instead as a very successful disidentificatory strategy - so successful that survival is hardly at stake anymore.

Muñoz - like Collins - considers creative works by queer of color artists the conceptual and theoretical center of his thinking, its incentives (1999: 5). Anaconda and Formation are similarly valuable not only as provocations for thought, or objects to which theories can be applied, but as thought and theory themselves. This can mean, for instance, that the task of scholarly reading highlights or creates connections between frameworks of thought, theories and concepts, be they in written, rapped, sung, shrieked, danced, or visual forms. It also means that rather than evaluating how successful the works or the artists are in their feminisms, we might ask what kind of work they do to reimagine feminisms, how the agency and liveness of creative works facilitate feminist and Black feminist theorisations, when understood as complex, heterogeneous organisms (Kontturi 2012).

Although Collins' epistemological theorisations for Black feminist thought form the backbone of this article, her work does not fit in easily with Black female artists who specifically explore sex, sexuality, desire and pleasure. Indeed, she has been critiqued by other Black feminist theorists for investment in sexual respectability politics. For example, Joan Morgan (2015: 39-40) notes that in her book Black Sexual Politics (2005) Collins prioritises a spiritual, more romantic form of the erotic over sex/fucking - a move that Morgan sees as counterproductive to radical sex-positive queer Black feminist politics (see also Cooper 2015: 12). Moreover, the relationship between Black feminist theory and queer of color critique is not one of self-evident coalition either, as Brittney C. Cooper (2015: 12-16) and Sharon Patricia Holland (2012: 77-81) have pointed out in their discussions of José Muñoz and Robert Ferguson (two seminal figures of queer of color critique), that despite crediting Black feminist theory for providing a foundation for their thinking, they nevertheless depict it as a thing of the past that has reached its limits and now needs to be superseded. Both Cooper and Holland see this move as unfortunate, since it dismisses the present dynamism as well as the investment in lesbian, bisexual, queer and trans questions within Black feminist thought. In my view, however, bringing together these strands of thought need not be seen as an obstacle, but a part of the inevitable dynamism of Black feminisms.

Since their rise to fame, Beyoncé Knowles and Nicki Minaj have also spurred a significant body of academic literature analysing their respective public personas and creative works from feminist, queer and critical race studies perspectives. For Beyoncé that happened in the late 1990s, first in the R\&B girl group Destiny's Child and then as a solo artist since the early to mid-2000s (e.g. Brooks 2008, Durham 2012, Chatman 2015, Weidhase 2015), and for Minaj in the late 2000s with her breakthrough rap/hip hop album Pink Friday released in 2010 (e.g. Whitney 2012, McMillan 2014, Shange 2014, Barratt 2016). Recently, a collection of academic essays was dedicated entirely to analysing Beyoncé, with the apt title The Beyoncé Effect: Essays on Sexuality, Race and Feminism (2016, edited by Adrienne Trier-Bieniek). The plentiful online commentaries on the album Lemonade (2016) have even been curated by Janell Hobson and Jessica Maria Johnson (2016) into A Black. Feminist Resource List on the website Black Perspectives. Notably, the vast majority of these commentaries have applauded the album for its Black feminist politics and deep affective appeal. In academic literature, Beyoncé and Nicki Minaj have been partly placed in similar genealogies of Black femininities and feminisms, such as in hip hop feminism, defined by Black feminist media 
scholar Aisha Durham as 'a cultural, intellectual, and political movement grounded in the situated knowledge of women of color from the post-civil rights or hip-hop generation' (Durham et al. 2013: 721; see also Crunk Feminist Collective 2010). On the other hand, while Beyoncé's creative work is keenly connected to exploring Black Southern femininity, as her roots lie in Louisiana and Texas (e.g. Brooks 2008, Durham 2012), Trinidadian-born Nicki Minaj has been placed in African diasporic and Caribbean feminist contexts (e.g. Barratt 2016; see also Morgan 2015). In the following, although I engage with their music videos side by side, one of my aims is also to highlight how some of the critiques directed at them might have originated from a lack of attention to the situatedness of their Black feminisms.

\section{SITUATED KNOWLEDGES AND ‘SELLING OUT’ TO WHITE PEOPLE}

Many commentators of both videos, but especially Formation, have pointed out that these are not cultural products made for white people, since everything is not and should not be about white people, contrary to what some white people may think. For example, Kady Ashcroft's sarcastically titled blog post The White Feminist Guide to Making Beyoncés Formation' Video About You (2016) addresses and dismisses the shock that some white social media commentators expressed about not feeling included in the formation Beyoncé calls for. Saturday Night Live took the joke even further in their sketch The Day Beyoncé Turned Black (2016). In the sketch, the first notes of Formation are a prelude to a horror movie spoof where white people fall into fits of uncontrollable panic, dread and paranoia over the realisation that Beyoncé is not white and has never been white, not even in her hit song Single Ladies (2008). One horror-struck white mother even suspects that her daughter has become Black while listening to Beyoncé, only it turns out she has mistaken her daughter for her daughter's Black friend. Black people observe the mayhem with disinterested coolness.

As Zeba Blay (2016) points out in The Huffington Posts Black Voices section, Beyoncé has always been politically Black, but the problem is white people did not always notice or rather, did not pay attention to her Blackness or to her politics. Daphne A. Brooks (2008), for example, highlights the ways in which Beyoncé already expressly explored the complexities of Black women's agency, self-worth, desire, rage and desperation in her 2006 album $B$ Day, published one year after Hurricane Katrina, but her work has persistently been interpreted as 'just' personal rather than political. In Blay's (2016) words, however, a decade later 'she's situated so firmly at the top of the mainstream music food chain' that 'white fans (...) are being forced to engage with her blackness and black issues in a real way'.

I was not a fan of Beyoncé before the release of Formation - which turned me into a fan, together with the subsequent stunning visual album Lemonade - but I have been guilty of the exact same white ignorance of Beyoncé's political Blackness that Blay describes and Brooks critiques. However, Beyoncé's vast cultural influence, her position as someone who cannot be ignored, compelled me and many other white audience members to engage with the unavoidable political nature of Beyoncé's Black femininity, thus turning Formation into a powerful tool of Black feminist pedagogy. I had to come to grips with the fact that my dismissal of her work ("I'm just not into that kind of mainstream pop music") must have been a function of my taken-for-granted white privilege. Two years before Formation, Anaconda had already also forced me to check my white feminist preconceptions about what feminist music videos should sound and look like: my own bafflement in front of Anaconda's unapologetic focus on the Black booty disturbed me (“Am I really so prudish that I take offense at a song about butts?"), leading me to read more Black feminist theorisations of Black female sexuality in popular culture.

Simultaneously, writing about creative works by Black female artists as a white feminist obviously does not mean that I have power to explain what they 'really mean' (cf. Cooper 2015: 18-19), as if they needed my interpretation or validation. Of course, they neither need nor ask for any such thing. How, then, to write scholarly text in dialogue with creative works of Black feminist thought, so that one does not only end up reproducing the setting where Black feminist work is judged from the outside, from a white, dominant perspective? In my view, working with Black feminist thought as a white feminist scholar may place somewhat different demands on the commonly accepted aim of ethical feminist research practice to produce situated knowledges (e.g. Haraway 1991, Harding 2004) than if I was writing about white artists' work. Importantly, feminist standpoint theories (e.g. Harding 1993, Collins 2009) have challenged the false universality of white male-stream knowledge production by demanding accountability for the specificity of researchers' viewpoints, with a broader goal of transforming what counts as proper knowledge and placing particular value on experiences of subjugated groups and people. This has often involved intertwining autoethnographical and creative writing with theorising, notably by Black and feminist writers of color like Audre Lorde (1984), bell hooks (1992) and Sara Ahmed (2017). However, when engaging with Black feminist works as a white person, the risk is that too much self-reflection can become 'me-too-ism' or even lead to a re-centering of whiteness (Wiegman 1999). When do accountability and situatedness turn into unnecessary and counterproductive gestures, more efficient in easing white guilt than unravelling racialised power structures in academic writing? 
On the other hand, the choice to not interrogate one's positionality and implicatedness in racialised power relations could either turn into an extremely problematic, implicit appropriation of a Black feminist voice (which might be assumed from work engaging with Black feminism, if not otherwise specified), or a continued muteness about and dismissal of Black feminist thought, its redaction to a side note or an intervention in (white) theory and feminism (Cooper 2015: 14-16). In her classic article The Problem of Speaking for Others (1991) the Mestiza feminist philosopher Linda Alcoff examines how the fear of the privileged to speak on behalf of the oppressed has sometimes resulted in a reluctance to even speak about oppressed groups one is not a part of. This, then, in effect just continues histories of silencing and lack of recognition. Black, indigenous and women of color feminisms do not need white permission or acceptance to be included, but they are also not to be ghettoised as something white feminists only need to be marginally aware of (Arvin et al. 2013). Thorough engagement by white scholars is important, while that engagement simultaneously requires much care about what kind of knowledge authority one adopts in relation to whom.

Also Collins (2009: 36-43) explicitly rejects exclusionary definitions of Black feminism as something that only Black women can participate in and produce. Instead, she emphasises that the connections between branches of Black feminist thought and Black women - with no fixed borders - should be ones of self-definition. Following Collins, my (partial, imperfect) solution to the dilemmas above is two-fold: first, rather than evaluate whether Anaconda and Formation are or are not feminist, I assume that they are, as both Beyoncé and Nicki Minaj have been outspoken about self-defining as feminists (see Carmen 2014). Secondly, I regard the scholarly work I produce here as an act of recognition for and engagement with the complexity of Black feminist thought as integral to feminist thinking overall, more than a 'critique'.

From another perspective, it may seem rather pompous to ponder on my position as a position of privilege in relation to Beyoncé and Nicki Minaj who are both extremely wealthy and culturally influential, beyond anything that a European middle class academic like me could even distantly aspire toward. Beyoncé and Minaj have broad and diverse fan bases across racialised divides, given that they are some of the most successful women and people in the music industry on a global scale. Such vast success and wealth seem to have blurred the gendered lines between Black and white cultures, even to the extent that white people 'did not notice' that Beyoncé is Black, and some Black women commentators did not see her as political either before Formation (see e.g. Keleta-Mae 2016, D’Oyley 2016). Furthermore, Beyoncé's and Minaj's well-known and well-advertised wealth goes a long way to show how deep the differences between Black women can be in terms of socioeconomic status and everyday experiences, as well as how their Black feminist strategies cannot be seen to represent the interests of all women or feminists, Black or not.

Thus it is hardly surprising that some Black thinkers have criticised Beyoncé and Nicki Minaj for 'selling out' to white capitalism, among the most notable of them the famed Black feminist thinker bell hooks (hooks et al. 2014, hooks 2016). hooks has criticised them, respectively, for sexually objectifying their bodies - which, according to hooks, do not diverge too far from white beauty ideals - in order to make money, and doing nothing to uplift other Black women. Thereby they necessarily submit to the conditions of white supremacist capitalist patriarchy in exchange for becoming ultra-rich. hooks even goes as far as to call them not only anti-feminist, but in Beyoncé's case, a terrorist (Coker 2014). Notably, for some Black female viewers, the refusal to locate Black female artists under the rubric of feminism could have also been connected to a critique of feminism's unspoken whiteness, its historical and continued disinterest in the empowerment of Black women. This does not necessarily mean that such publics would not regard Black female artists' work as potentially empowering for Black women (see e.g. Springer 2005: 88-101). However, in hooks' critique, the judgment 'not feminist' was clearly used as a synonym for the lack of potential for real empowerment.

It seems though that both artists predicted this critique and responded to it already in their songs and music videos in their own ways, and on their own terms. In Anaconda, Nicki Minaj's writhing in heavy golden jewelry in the faux jungle is interrupted by poses in a corseted dress and extremely high heeled shoes by fashion designer Alexander McQueen, while she raps:

\footnotetext{
Boy toy named Troy used to live in Detroit

Big dope dealer money, he was gettin' some coins

Was in shootouts with the law, but he live in a palace

Bought me Alexander McQueen, he was keeping me stylish

Now that's real, real, real
}

Minaj brags about money in the video (which she often does, cf. Shange 2014: 34-35) and about her unapologetic gold-digging, how she benefits from the darker sides of capitalism ('dope dealing') and male gullibility so that she can wear Alexander McQueen and 'keep stylish'. This, of course, appears immediately as a joke, since Minaj hardly needs anyone to buy her designer clothes, or the 'coins' from 'Troy' in Detroit. The comic nature of Minaj's story about Troy is underlined in her non-reassuring assurance 'that's real, real, real' which she raps drawing 
out the last 'real' - mocking Black male rap culture's emphasis on authenticity as criminality and drugs, emphasising her own form of glamorous artifice instead (Whitney 2012). Indeed, the quick cuts between the faux jungle scenery and Minaj's designer style poses also poke fun at the primitivism traditionally connected to Blackness in whitedominated popular culture (Hobson 2008).

For Beyoncé in Formation, money equals power equals revenge, and she has got it all. She articulates this quite explicitly as she sings towards the end of the song:

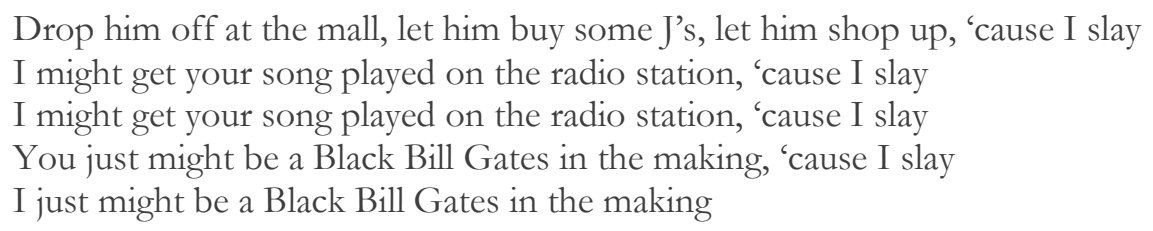

And, at the very end of the song and the video, she raps in what sounds like a cross between a moan, a halfwhisper and a growl: "You know you that bitch when you cause all this conversation - always stay gracious, best revenge is your paper". In Formation, Beyoncé is the one who might allow her lover to go shopping, even get his song played on the radio, because she has the power to do that, as in 'slay'. She is ready to take over the throne of a white male icon of wealth and make it Black - and female.

If Beyoncé was white, I would be inclined to agree with hooks' reading of Formation as a celebration of capitalism. However, when we consider the larger cultural and historical context of Black people in the United States, the situation looks wholly different. The wealth of the whole nation has essentially been carved out of the lives and skins on the backs of Black slaves and Native peoples, and out of the continued economic exploitation of people of colour in low paying jobs (see e.g. Collins 2009: 51-75). American popular culture bears the marks of this exploitation hidden in plain sight, for example in the stereotypes of the welfare queen, the mammy and the hoochie, as hooks herself has pointed out elsewhere (1992). While critique of capitalism is vital for feminist thought, aspiration toward and success in accumulating wealth - and not just wealth in general, but such wealth that it translates to great cultural influence, even domination - do not carry the same meanings for Black people in a culture built on their exploitation than it does for white people. Nicole R. Fleetwood (2011) has argued that, in fact, Black women's popular cultural performances are quite habitually critiqued of 'selling out' or selfcommodification, to the extent that 'the discourse of captivity and capital (...) frames the black body in the field of vision' (ibid: 127). Although it is important to understand the connections between the current cultural commodification of Black bodies and the history of Black bodies as commodity goods in trans-Atlantic trade, Black authorship, production and economic benefit from such popular cultural performances makes a crucial difference (Fleetwood 2011: 128).

Black feminist thinker, writer and poet Audre Lorde famously said "the master's tools will never dismantle the master's house" (1984: 112). But what if they sometimes did just that? It seems to me that what is at stake might just as well be an ingenious infiltration strategy. Beyoncé and Minaj may both have made themselves seem a bit less threatening and thus more marketable for the white dominant public by utilising some of the master's tools, such as idealisation of mega-richness, even to the extent that their Blackness has faded from (conscious) white view, and played with the trope of commodification of Black female bodies to appear less threatening. Thereby they have made themselves formidable forces inside the master's house. But once they are firmly inside the master's house, they actually have a chance to rule it, to be 'that bitch' - and consequently, thoroughly dismantle the house and redefine the tools.

For Black women to become ultra-rich can be about turning around and benefitting from, even mastering and transforming the very system that has produced the oppression of their ancestors and their people in the present. This appropriation of history is made quite explicit in the many shots in Formation where Beyoncé is surrounded by other Black women, dressed in long white antebellum style dresses, holding sun umbrellas and fans, sitting inside what looks like a Southern mansion, taking over poses and settings which have before belonged to white women and white desirable femininity in the South. Moreover, Beyoncé's (then) four-year-old daughter Blue Ivy (b. 2012) poses and plays in a white dress with other Black little girls in a similar setting, the camera angle from below, emphasising their effortless overtaking of previously white-dominated spaces. In Anaconda, racial appropriation takes the form of boasting about 'big dope dealer money', mocking white stereotypes of Blackness, and tongue-in-cheek adoption of signs of white wealth through white fashion designer clothing. Formation and Anaconda throw Beyoncé's and Nicki Minaj's Black wealth back in white capitalism's face, and with a combination of danger and humor, showcase their vengeance as their ability to use and abuse, or 'slay', American capitalism for their gain, when it rose out of their people's subjugation.

Of course, Black women do not become revolutionaries merely by the virtue of becoming rich. Collins (2009: 74-75) and Chatman (2015) warn about the possibility that some successful Black women may actually end up fostering other Black women's oppression, if they adhere to narratives about individual heroic success and its 
equation with wealth - as current neoliberal ethos would have it - and do not work for building solidarity, coalitions and alliances (see also Cohen 1997). When approached as Black feminist thought, Formation and Anaconda thus set the stage for important questions about how to build feminist alliances.

\section{POLITICS OF THE BLACK BOOTY - SEXUAL OBJECTIFICATION OR DISIDENTIFICATION?}

bell hooks $(2014,2016)$ and some other critics (e.g. Chatman 2015, White 2013) have connected Beyoncé and Nicki Minaj to a postfeminist sensibility, arguing that they are model postfeminist subjects in terms of how their bodies are represented in a sexualised and normative manner for the white straight male gaze, even though they claim pleasure in and authorship over their bodily performances. According to Rosalind Gill (2007), that is exactly how the contemporary postfeminist sensibility functions: the illusion of choice and sexual subjectivity maintains the culture of normalised sexual objectification of women, in compliance with heteronormative, white, slim and rigidly regulated body ideals. These two features: the (self-)objectification and (over-)sexualisation of Black female bodies, and an emphasis on personal achievement instead of alliances, are two common critiques that Beyoncé and Nicki Minaj have faced. How do Anaconda and Formation answer to these critiques?

Both music videos set body politics and the bouncing and overtly sexual Black female body - in Anaconda, even more specifically the Black female booty (see Fleetwood 2011, Durham 2012) - at their center. However, it is worth asking if the repeated feminist critique of how women's bodies are objectified in the media might not sometimes too easily produce the already-known conclusion: when there is a Black bouncing booty on the screen, it must be about objectification, commodification, and reproduction of dominant, racialised body norms. In other words, the expectation of seeing stereotypical portrayal - most understandable due to the long-standing employment of reductionist stereotypes in the white imagination - may oversensitise to seeing them everywhere (Shohat et al. 1994: 199), even in works controlled by and created on the terms of Black feminists. Indeed, hooks' condemnation of what she sees as Black female artists' sexual self-objectification can be placed in the same tradition of feminist investment in sexual respectability politics that Cooper (2015) and Morgan (2015) critique Collins for. Even if sexual respectability politics has been an important strategy to fight against the hypersexualisation of Black bodies, it may have become a habit that inadvertently obscures the value of some Black feminist works.

Fleetwood (2011: 115-118) argues that Black female artists, in the visual arts as well as in hip hop music videos, have used ironic appropriation of the hypervisible Black female 'back' or booty to knowingly explore and remix its history of sexual exploitation towards pleasure defined on their own terms. Fleetwood (2011: 113-137) analyses how artists Renee Cox and Ayanah Moor have both done this through referencing, in photographic and video art work, the same Sir Mix-a-Lot song Baby Got Back as Nicki Minaj does. Similarly, it can be argued that as a creative work of Black feminist thought, Anaconda also takes up traumatic tropes of how Black women's bodies have been treated and portrayed, but adopts, appropriates and redefines these tropes from a Black feminist perspective, exploring Black female pleasure.

Furthermore, self-definition need not be seen as divisive or individualistic, even when and perhaps particularly when enacted by superstars with broad cultural and economic influence. Instead, Beyoncé and Minaj can be seen to suggest coalitions, since both videos place queer of color and Black queer culture in the center of feminist and anti-racist struggles. For example, the central samples of Big Freedia and Messy Mya's voices, as well as images of punks and queers of color in Formation, make such engagements clear. In Anaconda, Nicki Minaj and other women in the video touch and are touched by each other in ways that suggest eroticism between women, caressing and slapping each others' butts, wrapping their bodies around each other. For Minaj, the video thereby continues her history of insinuations and flirtations around same-sex desire which have regularly peppered her lyrics, videos and interviews - in what Savannah Shange (2014) calls a 'strategic performance of queer femininity' which seemingly flirts with both queer and straight identity but ultimately refuses both.

Beyoncé has been critiqued before by scholars such as Susan Bordo (2003: xxii) for almost complete compliance with white beauty ideals, with her flowing blondish hair, her light complexion, facial features that appear 'white enough', and curvaceous but muscular and toned body. Also Collins $(2005,27)$ has accused Beyoncé (notably preFormation) in 2005 and critiqued her, alongside Jennifer 'JLo' Lopez (as did Bordo), for using 'bootyliciousness' as a personal selling point under the guise of body positivity and sexual self-empowerment. Wendy A. Burns-Adolino (2009), in her discussion of the racialised big butt and its commercial power in American pop music, argues that there is no way to fully shake the origins of that power in racist objectification, exoticisation and sexism. But would there not be other ways to approach the matter? Let us take a closer look at Anaconda.

Jennifer Dawn Whitney (2012) and Uri McMillan (2014) have both pointed out that Nicki Minaj's whole artist persona has, for the past decade, been constructed on the celebration of artifice, excess and Black female camp. For example, Minaj has explicitly parodied white femininity, worn white-blond, pink and other pastel-colored wigs and performed in extravagant clothes that accentuate a very knowing form of artifice and imitation, for example 
as she has posed as the icon of white beauty, the Barbie doll (Whitney 2012). In light of this, one of the most striking features of some academic interpretations of Minaj's performances (e.g. hooks 2014, White 2013) is that her performing persona is taken at face value, without specific consideration of the intricacies of comedic or campy self-representation - what could be called, following Muñoz (1999), disidentification. According to Muñoz, the relationship between dominant and marginalised cultures is necessarily more complicated than either adoption or rejection but often takes the shape of 'disidentificatory desire' for a 'toxic representation' (ibid.: 3). Performers outside of white heteronormativity can knowingly take on, embody, twist, exceed and mock white dominant stereotypes of queers and of people of color, but this disidentification is a strategy of survival and self-definition, never mere repetition of dominant cultural tropes.

Disidentification can also be seen as a key strategy of survival in the tradition of Black women's humour and comedy which has long played with, utilised and appropriated white dominant culture's images of Black women (Nishikawa 2017). According to Bambi Higgins (2007), Black women's comedic authorship has played an important role in paving way for Black women's success and recognition in the entertainment industry, especially since in the white imagination, Black women often appear either tragic figures or targets of mockery (or both at the same time). When explored as comedic racial masquerade (Nishikawa 2017) or racial camp (Robertson 1996: 19-21), Minaj's Anaconda appears an obvious disidentificatory performance of the hypersexual, excessive and deviant Black 'bad bitch' - but brought to such levels of excess and camp that it turns against and mocks the white dominant cultural stereotype it appears to mimic. After all, Minaj made a hit song about her own ass which she parades in front of viewers - but only to be seen, not to be controlled, touched or used like in the white male imagination, as the final scene of the video where Minaj slapps away Drake's hand during a lap dance makes crystal clear. The disidentificatory strategy of simultaneously utilising and mocking dominant images is apparent also in juxtaposition of the jungle imagery, where Minaj and her dancers bounce and slap their own and each others' butts while staring directly at the viewer, and the kitchen where Minaj, dressed in a pink wig and a French maid costume, slices, cuts and eats a banana - easily interpretable as a phallus symbol, as well as mockery of the tradition of equating Black bodies to exotic animals, 'monkeys' or vegetation.

Aisha Durham (2012), who has studied Beyoncé's music videos as well as hip hop feminism more broadly, argues that in Beyoncé's earlier video Check On It (2005), the emphasis on her butt is an attempt to reclaim the commodified Black female booty into signaling sexual agency, pleasure and Southern working class hip hop authenticity instead - especially through the backward gaze. The backward gaze became Beyoncé's signature move and it means, in short, gazing back towards viewer over the booty - which is an image convention that derives from pornography but becomes more respectable and more demure, not as challenging and insistent in music videos (Durham 2012: 41-44). Interestingly enough, the cover image of Anaconda featuring Nicki Minaj squatting in a pink thong, looking over her shoulder towards the viewer, is a version of the backward gaze, which one does not see in Beyoncé's Formation video at all. In this cover image, Minaj never turns her gaze away, never closes her legs, never covers her booty, and never hides the pornographic implications of her backward gaze.

Writer Carmen (2014) analyses why Minaj has received far harsher feminist critique than Beyoncé: "she's not polished, she's not concerned with her reputation, and she's certainly not fighting for equality among mainstream second-wave feminists". Indeed, as Carmen points out, Minaj is not interested in respectability but in selfdetermination, while she has repeatedly identified publically as feminist. In comparison, Beyoncé can also be seen to perform explicit sexual desire (in Formation: "When he fuck me good I take his ass to Red Lobster") but more safely in the context of heterosexuality and her very public marriage to rapper Jay-Z (Shawn Carter, b. 1969), thus embodying a more respectable form of straight feminist sexuality in a 'common people's' kind of way, making a working class specific inside joke about the Red Lobster restaurant chain which only seems fancy if one is not wealthy.

To continue the exploration of $A$ naconda's allegiances with queer of color culture, it is necessary to take a closer look at the booty-focused dancing, or 'twerking', prominently featured on the video. This is also a point where Anaconda and Formation intersect. 'Twerking' originates in long-standing dance traditions and dancehall culture in various African, Caribbean and African-Caribbean diasporic cultures, in a style of movement where hip movements are isolated flamboyant dress. However, as a term and a particular dance style, 'twerking' has its roots in the late 1980s and early 1990s Black New Orleans culture, particularly queer of color culture in the area (see Gaunt 2015). It is a dance style associated with bounce, upbeat dance-oriented rap music, mastered by queer of color performers like the legendary Big Freedia - who also features on Formation, her voiceover shouting on the video: "I did not come to play with you hoes, I came to slay, bitch!" Now, if all the twerking and 'booty popping' on Anaconda is looked at from a white perspective that only knows twerking through the likes of Miley Cyrus (cf. Gaunt 2015), this powerful alliance is fully missed. It may also be missed if the viewer fails to locate Minaj's feminism in the Afro-Caribbean diasporic context, or trace the references to New Orleans queer culture and voices in Formation. When I first saw both music videos, I certainly missed these connections. This exemplifies also how Anaconda and Formation can work as Black feminist pedagogy: they do not spell things out or take on the burden of educating 
white (or otherwise unaware) audiences, but they display enough hints - voices, sounds, movements of bodies, words, images - for the viewer to wonder about, follow and find a way to educate themselves, if they feel so compelled.

In the case of Formation, the alliance with queer of color politics is enforced through appearances and voiceover by queer of color performers and artists - in addition to the previously mentioned Big Freedia, also Black trans/queer YouTube performer Messy Mya speaks posthumously in it. Messy Mya was murdered in New Orleans in 2010 and their voice asks in the beginning of the video "What happened after New Orleans?", in addition to samples from their YouTube videos, such as the shriek "Ooooh I like that" and "Bitch I'm back by popular demand" (see e.g. Robinson 2016, O'Connor 2017). One of the heaviest critiques directed at Formation comes nevertheless also from self-identified queer and trans people of color, such as rad fag (2016) who states, among their other criticisms of Beyoncé:

The appropriation of queer and trans genius by straight, cis people is real. As a queer Black person I feel betrayed by straight, cis, Black people who are celebrating this video instead of defending queer art and culture from corporate ravaging.

Indeed, Messy Mya's estate has sued Beyoncé in 2017 for insufficient compensation for using Mya's vocals (O’Connor 2017). rad fag further points out how Beyoncé has adopted the word 'slay' for cis use, when it also prominently derives from queer of color culture as a term for fabulousness and domination against all odds. Big Freedia herself has simply expressed pleasure in having been invited to collaborate with Beyoncé, and does not see Formation as exploitation but rather as a creative opportunity that gave her more exposure and performance work (Lockett 2016). rad fag's critique obviously rises from a popular cultural context where, for example, trans people are persistently portrayed by cis actors in film and TV, and Beyoncé's samples of Big Freedia and Messy Mya can hardly be seen as collaborations between equals. From their perspective, the video thus functions more divisively than as an invitation for coalitions. But does the critique about divisiveness also reproduce and maintain divisiveness? What would a politics and a reading of coalition look like instead?

\title{
GET IN FORMATION: COALITIONS AMONG MARGINALISED SUBJECTS
}

\author{
In her blog New South Negress, Zandria Robinson (2016) writes that Formation
}

$[\ldots]$ is a metaphor, a black feminist, black queer, and black queer feminist theory of community organizing and resistance. It is a recognition of one another at the blackness margins - woman, queer, genderqueer, trans, poor, disabled, undocumented, immigrant - before an overt action. For the black southern majorettes, across gender formulations, formation is the alignment, the stillness, the readying, the quiet, before the twerk, the turn-up, the (social) movement.

Robinson refers to Cathy Cohen's (1997) call for coalition politics among 'punks, bulldaggers and welfare queens', among marginalised subjects of all kinds. Cohen argues that a queer politics that subscribes to categorical differences between straights and non-heterosexuals at the expense of attention to race, gender and the situationality of marginalisation is doomed to fail, and the same applies to other binary differences, if not approached through each other. Robinson also sees Formation as Black feminist theory, but more specifically Black queer feminist theory and stand-point epistemology, aligned with, sometimes only detectable from, and lead by the margins.

Following Cohen and Robinson, Black feminist thought can be understood as a process of alignment and formation before the movement, not as a project that has failed unless it is 'completed'. Seen this way, the voices that dismiss Formation as ineffective in producing anything else than more money for Beyoncé seem to demand the impossible, since the process, the formation, the alignment cannot happen overnight. When Black feminist thought is understood to be about coalitions and alliances, Formation can also be evaluated through the alliances shaped around it: many Black, white and people of color thinkers and feminist activists have found opportunities for coalition around it, and even more so around the full complex album Lemonade, even if bell hooks did not (e.g. Hobson \& Johnson 2016, Adelman 2016). When taken as Black queer feminist thought, Formation does not necessarily reject whiteness, but offers a situational uniting behind Black, queer feminist politics - just not under white terms. In other words, Formation addresses whiteness but does not specifically invite or include white audiences.

Anaconda as Black feminist thought also aligns itself with Black feminist standpoint epistemology in terms of claiming that one can see better from the margins, but privilege necessarily obscures one's vision. Nowhere is this more obvious than in the controversy around Anaconda's claimed 'skinny bashing', based on the lyrics towards the end of the song: 
Yeah! This one is for my bitches with a fat ass in the fucking club

I said, Where my fat ass big bitches in the club?

Fuck them skinny bitches, Fuck them skinny bitches in the club

While Minaj raps these lyrics, she lets out shrieks of laughter, and on the video, she begins her infamous lap dance scene in a night club resembling environment, in black-blue light, with just her and Drake in the room. These lyrics are the main issue that has been named when Minaj's Black feminism has been accused of divisiveness instead of coalition (e.g. Veiga 2014). Even though she explicitly celebrates non-normative bodies, Black female fatness, booty and bodily excess (cf. Fleetwood 2011), her empowerment appears to come at the expense of the disempowerment of other women: skinny women, or perhaps even more specifically skinny white women. Indeed, 'skinny bitches' can be perceived also as a euphemism for white women.

However, this accusation of 'reverse oppression' makes little sense, when Anaconda is considered Black standpoint feminist theory as well as a view from the margins. First of all, Minaj reclaims the word 'fat' in Anaconda, as the field of feminist fat studies has been doing for some decades (e.g. Rothblum \& Solovay 2009, Kyrölä \& Harjunen 2017), turning the mocking word 'fat' into an empowering one, just like queer activists did with the word 'queer' earlier. Secondly, her 'fuck off states to those with thin and white privilege that this is not a space for the privileged to take. The 'skinny bitches' are addressed - they are not ignored, like Black and/or fat women so often have been, but they are knowingly excluded. This is even repeated on the level of the image: there are in fact no 'skinny bitches' in the club, and no other 'bitches' at all, there is only Nicki Minaj who dominates the space, and passive, submissive Drake sitting in a chair, under her command.

As several scholars have shown (e.g. Song 2014, Titley 2016, Daniels 2016), cries of 'reverse racism' or 'reverse oppression', particularly in social media, tend to function primarily to deflate, de-contextualise, de-historicise and overly broaden what racism and marginalisation mean. Miri Song calls this 'a wide-spread culture of racial equivalence, in which all interactions involving some reference to race or cultural difference are deemed racist' (2014: 118). As Jessie Daniels (2016) has shown in her analysis of three cases of white feminist activism online, women of color feminist work is habitually accused of divisiveness - which she sees is a divisive move in its own right and necessitates critical interrogation of white feminist practices. In a similar manner, the calls to see Formation as 'reverse racism' and Anaconda as 'skinny bashing' only serve to deflate them as creative works of Black feminist thought. Song's (2014) suggestion is to carefully tend to the specific contexts where claims of reversibility and equivalence can be expressed and amplified through repetition in social media. In the case of Formation and Anaconda, these claims, despite gaining a fair amount of publicity, did not manage to get amplified to the degree of deflation. Why not?

In his article Does the Whatever Speak? (2012), Alexander Galloway refers to Gayatri Chakravorty Spivak's classic article Can the Subaltern Speak? (1988) but examines her arguments' validity for the digital era. Spivak's concern was that the Subaltern has no voice from the perspective of white western knowledge production, but according to Galloway, in the digital era anyone and anything can speak - there is no one without a potential voice. The question is, then, not who can speak and for whom, but who is the noisiest. When considering online debates and controversies, what is at stake is not so much a politics of exclusion but a politics of subsumption. Black supercelebrities, like Beyoncé and Nicki Minaj, have at least momentarily managed to subsume the (white) public eye, despite living in a white-dominated society. Their creative works of Black feminist thought have ultimately been noisier and managed to build broader coalitions than their critics - which they arguably might not have been able to do, had they not also exposed themselves to critiques about 'selling out'.

From this perspective, both Anaconda and Formation are powerful creative pieces of Black feminist thought powerful not only because of the tens or hundreds of millions of views they have received, but powerful as loci for public debates about race, gender and sexuality, and powerful as loci for coalitions. By respectively calling for formation and for the privileged to 'fuck off, they have managed to engage feminists across racialised and sexual identifications in public formations - perhaps preludes to social movements.

\section{ACKNOWLEDGEMENTS}

Thank you to the special issue editors for their supportive input and to the anonymous reviewers for their generous and pedagogical engagement which greatly helped develop my thinking.

\section{REFERENCES}

Adelman, L. (2016). A Black feminist roundtable on bell hooks, Beyoncé and "Moving beyond the pain". Feministing.com, 11 May. Available at: http://feministing.com/2016/05/11/a-feminist-roundtable-on-bellhooks-beyonce-and-moving-beyond-pain/ (Accessed 14 April 2017). 
Ahmed, S. (2017). Living a Feminist Life. Durham: Duke University Press.

Alcoff, L. (1991). The problem of speaking for others. Cultural Critique, 20, pp. 5-32.

Arvin, M., Tuck, E. \& Morrill, A. (2013). Decolonizing feminism: challenging connections between settler colonialism and heteropatriarchy. Feminist Formations, 25(1), pp. 8-34.

Ashcroft, K.R. (2016). The white feminist guide to making Beyoncé's "Formation" video about you, Funny or die blog, 8 February. Available at: http://www.funnyordie.com/articles/fd5c414919/ the-white-feminist-guide-tomaking-beyonce-s-formation-video-about-you (Accessed 16 April 2017).

Barratt, S.A. (2016). What's in a name?: Nicki Minaj, Indian in/visibility, and the paradox of dougla feminism. In: G. Hosein and L. Outar, eds., Indo-Caribbean Feminist Thought (pp. 225-240). New York: Palgrave Macmillan.

Beyoncé (2016). Formation (Explicit). YouTube, 6 February. Available at: https://www.youtube.com/watch?v=LrCHz1gwzTo (Accessed 16 April 2017).

BeyonceVEVO (2016). Beyoncé: Formation. YouTube, 9 December 2016. Available at: https://www.youtube.com/watch?v=WDZJPJV_bQ (Accessed 16 April 2017).

Bitter Gertrude (2016). White people: shut up about Beyoncé. Bitter Gertrude blog, 8 February. Available at: https://bittergertrude.com/2016/02/08/white-people-shut-up-about-beyonce/ (Accessed 16 April 2017).

Blay, Z. (2016). Beyoncé has always been political - you just didn't notice. The Huffington Post, 9 February. Available at: $\quad$ http:/ / www.huffingtonpost.com/entry/beyonc $\% \mathrm{C} 3 \%$ A9-has-always-been-political-you-just-didntnotice_us_56b8d3d2e4b08069c7a827a7 (Accessed 16 April 2017).

Bordo, S. (2003). In the empire of images: Preface to the tenth anniversary edition. In: Unbearable Weight. Feminism, Western Culture, and the Body: Tenth Anniversary Edition (pp. xiii-xxxiv). Berkeley: University of California Press.

Brooks, D.A. (2008). “All That You Can't Leave Behind.” Black female soul singing and the politics of surrogation in the age of catastrophe. Meridians: feminism, race, transnationalism, 8(1), pp. 180-204.

Burns-Ardolino, W.A. (2009). Jiggle in my walk. The iconic power of the "big butt" in American pop culture. In: E. Rothblum and S. Solovay, eds., The Fat Studies Reader (pp. 271-279). New York and London: New York University Press.

Carmen (2014). Nicki Minaj's feminism isn't about your comfort zone. Autostraddle, 25 August. Available at: http://www.autostraddle.com/nicki-minajs-feminism-isnt-about-your-comfort-zone-on-anaconda-andrespectability-politics-251866/ (Accessed 14 April 2017).

Chatman, D. (2015). Pregnancy, then it's "back to business". Beyoncé, black femininity, and the politics of a postfeminist gender regime. Feminist Media Studies, 15(6), pp. 926-941. https://doi.org/10.1080/14680777.2015.1036901

Christian, B. (1988). The race for theory. Feminist Studies, 14(1), pp. 67-79.

Cohen, C. (1997). Punks, bulldaggers, and queens: the radical potential of queer politics? GLQ: A Journal of Lesbian and Gay Studies, 3(4), pp. 437-465.

Coker, H.C. (2014). What bell hooks really means when she calls Beyoncé a terrorist. Ježebel, 9 May. Available at: http://jezebel.com/what-bell-hooks-really-means-when-she-calls-beyonce-a-t-1573991834 (Accessed 7 May 2017).

Collins, P.H. (2005). Black Sexual Politics: African Americans, Gender, and the New Racism. New York: Routledge.

Collins, P.H. (2009 [1990]). Black Feminist Thought. Knowledge, Consciousness and the Politics of Empowerment. $2^{\text {nd }}$ edition. New York: Routledge.

Cooper, B.C. (2015). Love no limit. Towards a Black feminist future (in theory). The Black Scholar, 45(4), pp. 7-21.

Crunk Feminist Collective (2010). Hip hop generation feminism: a manifesto. The Crunk Feminist Collective, 1 March. https://crunkfeministcollective.wordpress.com/2010/03/01/hip-hop-generation-feminism-a-manifesto/ (Accessed 29 July 2017).

Daniels, J. (2016). The trouble with white feminism: whiteness, digital feminism and the intersectional internet. In: A. Brock, S. Noble and B. Tynes, eds., Intersectional Internet: Race, Sex and Culture Online. Oxford: Peter Lang.

Durham, A. (2012). Check On It. Beyoncé, Southern booty, and Black femininities in music videos. Feminist Media Studies, 12(1), pp. 35-49.

Durham, A., Cooper, B.C. and Morris, S.M. (2013). The stage hip-hop feminism built: a new directions essay. Signs: Journal of Women in Culture and Society, 38(3), pp. 721-737.

D’Oyley, D.L. (2016). No, sexism is not the main reason Beyoncé was criticized and Kendrick Lamar wasn't. The Root, 18 February. Available at: http://www.theroot.com/no-sexism-is-not-the-main-reason-beyonce-wascriticize-1790854297 (Accessed 16 April 2017).

Ferguson, R.A. (2004). Aberrations in Black. Toward a Queer of Color Critique. Minneapolis: University of Minnesota Press.

Fleetwood, N.R. (2011). Troubling Vision. Performance, Visuality, and Blackness. Chicago: University of Chicago Press. Galloway, A.R. (2012). Does the whatever speak?. In: L. Nakamura and P.A. Chow-White, eds., Race after the Internet (pp. 111-127). London: Routledge. 
Gaunt, K.D. (2015). YouTube, twerking \& you: context collapse and the handheld co-presence of Black girls and Miley Cyrus. Journal of Popular Music Studies, 27(3), pp. 244-273.

Haraway, D. (1991). Simians, Cyborgs, and Women. The Reinvention of Nature. London: Free Association Books.

Harding, S. (1993). Rethinking standpoint epistemology: what is "strong objectivity"?. In: L. Alcoff and E. Potter, eds., Feminist Epistemologies (pp. 49-82). New York \& London: Routledge.

Harding, S. (2004). Introduction: standpoint theory as a site of political, philosophic, and scientific debate. In: S. Harding, ed., The Feminist Standpoint Theory Reader (pp. 1-15). New York \& London: Routledge.

Higgins, B. (2007). Laughing Mad. The Black Comic Persona in Post-soul America. New Brunswick: Rutgers University Press.

Hobson, J. (2008). Digital Whiteness, Primitive Blackness. Feminist Media Studies, 8(2), pp. 111-126.

Hobson, J. and Johnson, J.M. (2016). \#Lemonade: a Black feminist resource list. Black Perspectives, 12 May 2016. Available at: http:/ / www.aaihs.org/lemonade-a-black-feminist-resource-list/ (Accessed 29 July 2017).

Holland, S.P. (2012). The Erotic Life of Racism. Durham \& London: Duke University Press.

Hooks, B. (1992). Black Looks. Race and Representation. Boston: South End Press.

Hooks, B., Czarnik-Neimeyer, A., Lynnee, D. and Troutman, S. (2014). Whose booty is this? bell hooks in an open dialogue with New School students. The New School, 10 October. Available at: https://www.youtube.com/watch?v=QJZ4x04CI8c (Accessed 16 April 2017).

Hooks, B. (2016). Moving beyond pain. The bell books institute, 9 May. Available at: http:/ /www.bellhooksinstitute.com/blog/2016/5/9/moving-beyond-pain (Accessed 14 April 2017).

Keleta-Mae, N. (2016). Get What's Mine: "Formation" Changes the Way We Listen to Beyoncé Forever. Vice Noisey, 8 February. Available at: https://noisey.vice.com/en_uk/article/beyonce-formation-op-ed-super-bowlperformance-2016?utm_source=noiseyfbuk (Accessed 16 April 2017).

Kontturi, K-K. (2012). Following the Flows of Process: A New Materialist Account of Contemporary Art. Doctoral thesis. Turku: Annales Universitatis Turkuensis B 349.

Kyrölä, K. and Harjunen, H. (2017). Phantom/liminal fat and feminist theories of the body. Feminist Theory, 18(2), pp. 99-117.

Lockett, D. (2016). Big Freedia on Slaying Beyoncé's 'Formation'. Vulture.com, 17 February. Available at: http://www.vulture.com/2016/02/big-freedia-on-slaying-beyonces-formation.html (Accessed 16 April 2017).

Lorde, A. (1984). Sister Outsider. Essays and Speeches. New York: Crossing Press.

McMillan, U. (2014). Nicki-aesthetics: the camp performance of Nicki Minaj. Women \& Performance, 24(1), pp. 7987.

Morgan, J. (1999). When Chickenheads Come Home to Roost: My Life as a Hip-Hop Feminist. New York: Simon \& Schuster.

Morgan, J. (2015). Why we get off: moving towards a black feminist politics of pleasure. The Black Scholar, 45(4), pp. 36-46.

Muñoz, J.E. (1999). Disidentifications. Queers of Color and the Performance of Politics. Minneapolis: University of Minnesota Press.

NewsOne Now (2016). White feminists attack Beyoncé for being left out of "Formation". NewsOne, February 2016. https://newsone.com/3355014/white-feminists-attack-beyonce-for-being-left-out-of-formation/ (Accessed 16 April 2017).

NickiMinajAtVEVO (2014). Nicki Minaj: Anaconda. YouTube, 19 August. Available at: https://www.youtube.com/watch?v=LDZX4ooRsWs (Accessed 16 April 2017).

Nishikawa, K. (2017). Racial masquerade. In: B. Papenburg, ed., Gender: Langhter. Macmillan Interdisciplinary Handbooks. Farmington Hills: Macmillan Reference.

O'Connor, R. (2017). Beyoncé 'sued over Messy Mya sample' in Formation. The Independent, 8 February. Available at: http://www.independent.co.uk/arts-entertainment/ films/news/beyonce-messy-mya-formation-lawsuitlatest-music-video-youtube-jay-z-sony-a7568376.html (Accessed 7 May 2017).

Rad Fag (2016). My (apparently) obligatory response to 'Formation': in list form. Radical Faggot blog 10 February. Available at: https://radfag.com/2016/02/10/my-apparently-obligatory-response-to-formation-in-list-form/ (Accessed 16 April 2017).

Robertson, P. (1996). Guilty Pleasures. Feminist Camp from Mae West to Madonna. Durham: Duke University Press.

Robinson, Z. (2016). We Slay, Part I. New South Negress, 7 February 2016. Available at: http://newsouthnegress.com/southernslayings/ (Accessed 14 April 2017).

Rothblum, E. and Solovay, S. (2009). Introduction. In: E. Rothblum and S. Solovay, eds., The Fat Studies Reader (pp. 1-7). New York and London: New York University Press.

Saturday Night Live (2016). The Day Beyoncé Turned Black. Saturday Nigbt Live YouTube channel, 14 February. Available at: https://www.youtube.com/watch?v=ociMBfkDG1w (Accessed 16 April 2017). 
Shange, S. (2014). A king named Nicki: strategic queerness and the black femmecee. Women \& Performance: a journal of feminist theory, 24(1), pp. 29-45.

Shohat, E. and Stam, R. (1994). Unthinking Eurocentrism. Multiculturalism and the Media. London \& New York: Routledge.

Song, M. (2014). Challenging a culture of racial equivalence. The British Journal of Sociology, 65(1), pp. 107-129.

Spivak, G.C. (1988). Can the subaltern speak?. In: C. Nelson and L. Grossberg, eds., Marxism and the Interpretation of Culture (pp. 271-313). Urbana: University of Illinois Press.

Springer, K. (2005). Living for the Revolution. Black Feminist Organizations 1968-1980. Durham: Duke University Press.

Titley, G. (2016). The debatability of racism. Networked participative media and postracialism. Raster! blog, 17 February 2016. Available at: https:/ / raster.fi/2016/02/17/the-debatability-of-racism-networked-participativemedia-and-postracialism/ (Accessed 16 April 2017).

Trier-Bieniek, A. (2016, ed.). The Beyoncé Effect: Essays on Sexuality, Race and Feminism. Jefferson: MacFarland.

Veiga, D. (2014). It's a skinny shame: Nicki Minaj's Anaconda. Clutch, August 2014. Available at: http://www.clutchmagonline.com/2014/08/skinny-shame-nicki-minajs-anaconda/ (Accessed 16 April 2017).

Weidhase, N. (2015). 'Beyoncé feminism' and the contestation of the black feminist body. Celebrity Studies, 6(1), pp. 128-131, https://doi.org/10.1080/19392397.2015.1005389

White, T.R. (2013). Missy “Misdemeanor” Elliott and Nicki Minaj: Fashionistin’ Black Female Sexuality in HipHop Culture - Girl Power or Overpowered? Journal of Black Studies, 44(6), pp. 607-626.

Whitney, J.D. (2012). Some Assembly Required. Black Barbie and the Fabrication of Nicki Minaj. Girlhood Studies 5(1), pp. 141-159.

Wiegman, R. (1999). Whiteness Studies and the Paradox of Particularity. Boundary, 26(3), pp. 115-150.

Wikipedia (n.d.) Anaconda (Nicki Minaj song). Available https://en.wikipedia.org/wiki/Anaconda_(Nicki_Minaj_song) (Accessed 15 March 2017).

Citation: Kyrölä, K. (2017). Music Videos as Black Feminist Thought - From Nicki Minaj's Anaconda to Beyoncé's Formation. Feminist Encounters: A Journal of Critical Studies in Culture and Politics, 1(1), 08. https://doi.org/10.20897/femenc.201708

Copyright (C) 2017 by Author/s and Licensed by Lectito BV, Netherlands. This is an open access article distributed under the Creative Commons Attribution License which permits unrestricted use, distribution, and reproduction in any medium, provided the original work is properly cited. 
http://www.lectitopublishing.nl

https://www.facebook.com/LectitoJournals/

https://twitter.com/lectitojournals

$\mathcal{S}_{+}$https://plus.google.com/110901545130385419486

in https://www.linkedin.com/in/lectito-journals9a675010b/ 


\title{
Perceiving Shit as Shit: On the Grammar of Patriarchy in Solanas' SCUM Manifesto
}

\author{
Salla Peltonen ${ }^{1 *}$, Mio Lindman ${ }^{2}$, Sara Nyman ${ }^{3}$
}

Published: October 30, 2017

\begin{abstract}
This article investigates the ways in which Valerie Solanas takes on what we call the 'grammar of patriarchy' in The SCUM manifesto. We argue that the manifesto provides us with philosophical insights similar to those provided by thinkers such as Nietzsche, Butler, Adorno and De Beauvoir. We argue that the philosophical and critical value in the manifesto lies in Solanas' descriptions and her style of writing. In the manifesto, as well as in this article, conventions of philosophical writing, and feminist academic writing are challenged. By reading the manifesto as a philosophical text, the article focuses on questions of human life, death, hope, change, frustration, anger and love.
\end{abstract}

Keywords: Solanas, SCUM Manifesto, philosophy, critique, description

"The effect of fathers, in sum, has been to corrode the world with maleness. The male has a negative Midas Touch - everything he touches turns to shit" (Solanas 2004: 45).

\section{ENCOUNTERING THE SCUM MANIFESTO}

We first read Solanas during our undergraduate years. Solanas spoke to us in a way no philosopher or feminist writer had previously. Reading The SCUM Manifesto ${ }^{1}$ was almost like a conversion experience. We arranged reading groups and wanted everybody to read it. The text should be part of the curriculum, we thought, and we demanded a course in feminist philosophy, the first one to be held at our department. For us The SCUM Manifesto had the originality of a classic. It combined philosophy, politics, and ethics. Utopian in its content, although deeply embedded in the experiences of everyday life, the manifesto was an example of hardcore politics, anger, vision, judgment - but also philosophy.

Thinking with Solanas became a necessity in the philosophical environment of our undergraduate years, where we experienced a clash with both academia and philosophy. Not because of the content of philosophy (although sometimes that too; we learned how intertwined racism and sexism are with the philosophical canon), but because

\footnotetext{
${ }^{1}$ Valerie Solanas wrote The Scum Manifesto and started distributing the text in 1967 by selling it in New York City, charging ' $\$ 2$ for men and only $\$ 1$ for women' (Inkiel quoted in Fahs 2008: 606). The text has been published in several versions over the years, first in 1986 by Olympia Press. For an overview of the different versions see Fahs (2008: 606). In this article we use the 2004 version published by Verso, with an introduction by Avital Ronell. One version goes under the title 'S.C.U.M. Manifesto' as the acronym for 'society for cutting up men'. This version is still in circulation and appears, for example, in Sara Stridsberg's and Tiina Rosenberg's work on Solanas, although Solanas apparently never herself intended this acronym, but rather meant the title 'SCUM' to be read as 'scum' (Fahs 2008: 607; Rowe 2013: 79). Breanne Fahs writes that the version edited by Solanas' publisher Maurice Giordias was 'used to sell more books but never endorsed by Solanas' (Heller quoted in Fahs 2016: 261). Apparently, it was also Giordias who was originally the intended target the day when Solanas shot Andy Warhol, Mario Amaya and Fred Hughes. Solanas also borrowed a copy of the S.C.U.M. Manifesto from the New York Library and rewrote the title on the book and stated that S.C.U.M. Manifesto is based on The SCUM Manifesto by Valerie Solanas. She also wrote 'Lie! Fraud! Never, never!' to indicate her dissatisfaction with the text (see Fahs 2008; 604, Rowe 2014).
}

${ }^{1}$ PhD Student, Gender Studies at Ábo Akademi University, FINLAND

${ }_{2} \mathrm{PhD}$ (philosophy), Freelance writer whose research interests range from work/labour, to feminism and moral philosophy, FINLAND

${ }^{3} B A$ (philosophy), Freelance Writer, FINLAND

*Corresponding Author: speltone@abo.fi 
of the highly masculine, patriarchal and sometimes outright sexist environment we found ourselves in. We were eager to study; we read the classics and we read feminist theory, trying to make sense of our situation. Engaging with both the traditional texts of the philosophical canon as well as the classics of feminist theory - another kind of canon - changed our perspectives and our lives. We were challenged intellectually but we also experienced, as many before us, what it meant to be young, loud and what it meant not to count as one of the guys in a traditional and strongly masculine academic environment. We were taking on philosophy.

The philosophers at the department did not recognise Solanas as philosophically relevant, and we were told that her text was a political manifesto, and not to be taken seriously as philosophical writing. Obviously, this was a text written by a lunatic; 'wasn't she the one who shot Andy Warhol?' was a common reaction (see also Fahs 2008: 591, Rowe 2013: 75). The SCUM Manifesto was, as it often is, seen as an example of madness and radical feminism, a tradition that was understood as problematic as such. ${ }^{2}$ The Manifesto is often cited as one of the primary examples of the radical feminism of the 1960s and 70s, although Solanas herself never claimed to be a feminist and clearly distanced herself from all forms of identity politics. As students of Philosophy, we were told that we should know that philosophy has nothing to do with politics. Over the years, we have experienced frustration in trying to talk about gender, sexuality and power to philosophers and have been brushed off with slippery jokes and insinuations. Over ten years have passed since our initial encounter with The SCUM Manifesto, and we still keep on shouting, and writing, about Solanas. ${ }^{3}$

\section{READING SOLANAS AS A PHILOSOPHER}

In what follows we read Solanas as a philosopher and The SCUM Manifesto as a philosophical text. We argue that Solanas provides us with philosophical insights, similar to those of thinkers such as Nietzsche, Butler, Adorno and de Beauvoir. Inspired by the philosophy of Ludwig Wittgenstein (1997) and his concept of grammar and his philosophical 'method' of description, we investigate the ways in which Solanas takes on the 'grammar of patriarchy' through her writing, style and voice. We are not advancing an argument or a thesis about the Manifesto, as much as approaching the text by asking what philosophical relevance it can have and how it can subvert our habitual ideas of what 'the philosophical' amounts to. Solanas' manifesto, we claim, has critical value in that it roots its critique not in abstract, intellectual realms, in a theory about language, meaning or power, for example, but in the everyday: in ordinary language and in our shared human lives. Solanas draws connections between questions that can be made intelligible by presenting us with what can be described as a moral perspective; one that focuses on human life, death, hope, change, frustration, anger and love.

We explore what Solanas can teach us about the struggles of understanding a culture built around identity, violence and contempt. Solanas' text takes the form of a wound, a call for change, the lone voice crying in the wilderness that, paradoxically, reminds us of our shared life. Solanas speaks from the margins - and we suggest this position should be treated as a philosophical point of view; that is, we can learn something from her wounded, raw descriptions of a patriarchal form of life. The manifesto provides us with the kind of critique that does not distance us from reality, but rather rubs our faces right in what hurts and damages us. We elaborate on - sometimes using the anecdotal - the kind of existential attitude Solanas' Manifesto expresses. This attitude is connected to the struggles of understanding and to no more and no less than the daily struggle of living. In other words: we claim that the philosophical value of the text lies in how it deals with reality, and with what is real. SCUM Manifesto is a challenging and difficult text to read because of its style, its words and its affects. It teases out our gut reactions. This cannot be isolated from how we write. Rather than the traditional, cool and distant academic style of conspicuously presenting the argument - as we said, we have none - we do not try to hide in which ways we are moved, sometimes unsettled, by Solanas' perspective.

'Grammar of patriarchy' is what we call Solanas' brutal descriptions of violence, contempt and self-absorption as deeply ingrained elements in our form of life. In the manifesto, we get to see a culture of boredom and hate Solanas pinpoints the kinds of power structures and psychology that transform this culture into what it itself views as the most advanced form of life in the world. Solanas describes an existence or a form of life dominated by 'Big Daddy' who has a Midas Touch and who turns everything into shit. 'Daddy's girls' are the women in this world,

\footnotetext{
${ }^{2}$ Solanas herself is a queer figure in many senses of the term. For an overview of Solanas as a writer and in particular of The Scum Manifesto, see Rowe 2011; Fahs 2008, 2016; Ronell 2004, 2010; and McBean 2016. For a biography over Solanas, see Fahs 2014.

${ }^{3}$ As Avital Ronell aptly notes: "If you are pegged as a woman your scream might be noted as part of an ensemble of subaltern feints - the complaint, the nagging, the picking, the chatter, the nonsense by which women's speech has been largely depreciated or historically tagged.” (2004: 3-4).
} 
who appraise 'Daddy, and thereafter, other men' and who accept themselves as inferior (Solanas 2004: 44). But Solanas also announces the (potential) existence of SCUM, fuck-up crews and groovy thrill-seeking females 4 .

The conflict, therefore, is not between females and males, but between SCUM - dominant, secure, selfconfident, nasty, violent, selfish, independent, proud, thrill-seeking, free-wheeling, arrogant females, who consider themselves fit to rule the universe, who have free-wheeled to the limits of this 'society' and are ready to wheel on to something far beyond what it has to offer $[\ldots]$, and nice, passive, accepting 'cultivated', polite, dignified, subdued, dependent, scared, mindless, insecure, approval-seeking Daddy's Girls (Solanas 2004: 70).

The SCUM Manifesto can be read as a kind of cultural critique. When Solanas here speaks of Daddy's Girls and females and males, she is speaking of different perspectives we can have on life, of different cultural forms of belonging and ways of living, relating and to occupying public space. This is the way in which she reveals collective forms of identity, as gendered identities are bogged down in patriarchal relations. Solanas thus confronts us with the question of how gendered identities come between people. Solanas' SCUM marks a change in perspective, it is a description of a form of life that is not dead and does not seek to emulate corrupted gendered ways of living.

The SCUM manifesto actualises what Rita Felski (2015) aptly describes as the moods and modes of critique, but in a slightly different way than the tradition of critical theory that has dominated academic critique over the last decades. Felski describes how the hermeneutics of suspicion, the emphasis on subversion, irony and revealing the workings of ideology have presided in critical scholarship (see also Moi 2017). It would be tempting to read Solanas in this critical mode (asking what the text reveals, what it hides; to engage in a 'deconstructive' mode of reading), but in this article, we want to avoid and criticise this kind of reading as a precisely the kind of 'epistemic habit' that Felski and others have diagnosed. ${ }^{5}$ We claim that the text has critical, political and philosophical value, and that it hits at the core of the particular difficulties of judgment that feminist, queer and postcolonial critiques face and problematise. The manifesto brings out the logic and irrationality of a culture that understands gender as Identity, as fundamental to our being. But Solanas does not put her faith in 'men' or 'women'. For her, Man is dead. In her own way, Solanas challenges the idea and the collectivity that comes with identification and identity ${ }^{6}$. This perspective can be described as a kind of 'anti-normative' thinking. As Avital Ronell notes, Solanas was a kind of queer thinker long before queer theory existed (Ronell 2004: 17).

\section{CONTEXTUALISING SOLANAS AND THE SCUM MANIFESTO}

Most of the discussions of the manifesto focus in one way or another on Valerie Solanas as a person. Descriptions of her as a lunatic or radical feminist or man-hating lesbian are often intermingled with a suspicion toward taking anything written by a woman like that seriously (Rowe 2009). The manifesto and the figure of Valerie Solanas have both been hailed as the future of feminism and dismissed as an oxymoron in the history of feminism. Several writers have linked Solanas to second wave feminism and to the history of radical feminism (cf. Third 2006). In recent years, Solanas has become somewhat of an iconic figure for feminism (McBean 2016). The text itself has been read as carnivalesque, satire, irony, subversive and as nihilist and anarchist (cf. Fahs 2008, Haut 2007). When the manifesto is read as a critical text, it is read as satirical or utopian, and less so as critique to be taken seriously as critique. Although the commentary around the manifesto has been attentive to the insightful conceptual remarks and claims Solanas makes about patriarchy, violence, and gender, the text is rarely read in the context of philosophy or as having philosophical value.

Avital Ronell $(2004,2010)$ as a reader of the manifesto is an exception. Ronell discusses Solanas primarily as a writer but situates her in the philosophical canon by comparing her to the likes of Nietzsche, Goethe, Marx Freud, Derrida, Butler, and Deleuze, stating that "Valerie Solanas runs with the best of them" (Ronell 2004: 7). The common denominator is a critical distance to patriarchal patterns, thoughts and figures: the father figure, paternity as fiction and understanding gender as performative, and most importantly, as a cry for 'The Ends of Man' (Ronell 2004: 5). Ronell situating Solanas in this crowd, captures quite well some of the main aspects of Solanas' critique. Ronell acknowledges the historical surrounding of The Scum Manifesto, but the historicising gesture functions like an invitation for the reader to engage with the text as a part of a particular archive of thought, not as a gesture that

\footnotetext{
${ }^{4}$ Here it is important to note that SCUM for Solanas denotes an attitude, or a perspective, and functions as a metaphor for an alternative to destruction. The way SCUM presents us with a vision of an alternative has somewhat been overshadowed by the circulation of the S.C.U.M Manifesto, titled by Giordias.

${ }^{5}$ Cf. Heather Love (2014), Toril Moi (2009, 2017), Amanda Anderson (2009), Felski \& Anker (2017).

${ }^{6}$ Here collectivity is understood as collective forms of identification, or collective forms of thinking, similarly to the ways in which Heidegger writes about Das Man, or Nietzsche about collective forms of 'morality'; and thus, we do not have in mind forms of resistance or political struggle when we talk about collectivity.
} 
merely provides a 'setting', in which to put Solanas and her manifesto. She reads Solanas as a commentator, a critical thinker. However, she also describes her as 'a psycho', 'butch-dykey angry, poor, and fucked up' (Ronell 2004: 17). Solanas was all of the above, an icon, a thinker, a rebel. In our reading we are inspired by Ronell's approach in thinking about how we can read the manifesto as a philosophical text that simultaneously is a critique of a particular life form.

Although aware of the troublesome aspect of contextualising Solanas within the domain of philosophy - a tradition she herself gives the finger to - we claim that there is philosophical value in the text that goes beyond the domains of academic philosophy and feminism. Solanas is certainly an odd figure in the genealogies of feminism, and it is important to note here that in our reading of The SCUM Manifesto and Solanas, the idea is not to situate her within an intellectual legacy, legitimise her, pin her down or define her as belonging to a specific canon. The desire to do so is in itself a symptom, one could say, of the kind of culture Solanas so strongly distances herself from (collectivity, decency, academic quasi-activity). To sum up: Our viewing the manifesto as a philosophical text has nothing to do with domesticating it, or making it less dangerous. As we want to show, the opposite, rather, is the case.

\section{NO ARGUMENTS (DESCRIPTION)}

Life in this society, at best, an utter bore and no aspect of society being at all relevant to women, there remains to civic-minded, responsible, thrill-seeking females only to overthrow the government, eliminate the money system, institute complete automation and destroy the male sex (Solanas 2004: 35).

These are the opening words of The SCUM Manifesto. These words are of great importance in understanding the spirit of Solanas' work, and, we argue, understanding the spirit of her work might give us a deeper understanding of the questions feminists struggle with today. We emphasise spirit here as a way of capturing the way in which Solanas' Manifesto is not a theoretical text; she doesn't have a thesis and she doesn't argue. There are no positions to be defended in her texts - she provides her readers with a perspective. The power of her critique lies in her descriptions. ${ }^{7}$ Solanas' philosophical method, as it were, is descriptive and diagnostic; this is where its philosophical remarks can be seen. She doesn't need another language, theory or a thesis to think through. Her thinking appears in the descriptions she offers. She trusts the reader and she trusts language. She trusts us to know what concepts, such as 'contempt' and 'love' mean'. In her writing the moral meaning that concepts have in our lives becomes evident, and she shows this without needing to historicise, and without needing to provide a genealogy of for example 'love' or 'the family'. This is a crucial point. Although we can 'explain' the different ways in which historical and societal categories and concepts gain their meaning through historicising them, we are still left with the question of how to understand the challenges that they pose as political, moral and philosophical questions in our lives.

Solanas reminds us of how moral impulses and reactions like anger and despair have spurred feminist questions, critique and actions. These are concepts that in a sense provide theoretical discussions with their intelligibility, as they form the background of feminist thinking. One could say that feminist thinking is internally related to anger, despair, hope and love. This is the feminism we pledge our allegiance to, a feminism that doesn't find its feet in this world and therefore demands change, new worlds. As Avital Ronell writes in Fighting Theory: "Anger is in some sense the site of thought. One can be in states other than anger, but if there is no anger I don't see how one can think" (Ronell 2010: 25). In this text we direct our anger at what we call the 'grammar of patriarchy'.

\section{GRAMMAR AS A FORM OF UNDERSTANDING}

By 'grammar' we mean the kind of sense-making that patriarchy contains; what makes sense if one approaches life from a particular angle - when humanity is divided into the (damaging) dynamics of 'men' and 'women', to be

\footnotetext{
${ }^{7}$ Description is a central aspect of Ludwig Wittgenstein's philosophical method (1997) that focuses our attention on language use. Here we are inspired by Wittgenstein's descriptive method but also follow the work of Heather Love (2014) and Toril Moi (2017) in emphasising descriptions as the ways in which a literary text can reveal its philosophical and theoretical value. Description has for long been discarded as unanalytical against interpretation and analysis, and as such, seen as useless for scholarly work. Recently, description has gained some attraction, mainly in literary studies, as a means of approaching texts and as a way of reading (see Love, Best and Marcus 2016).

${ }^{8}$ This is what makes SCUM Manifesto a philosophical rather than academic text, and where we diverge from the 'epistemic habit' of understanding language as primarily performative (Sedgwick 2003), or of concepts being primarily in need of genealogical (Foucault) and deconstructive (Derrida) modes of analysis but rather emphasise a Wittgensteinian approach to language and meaning.
} 
more specific. 'Grammar', then, is our clear-sighted descriptions of the patterns in how we talk, how we think, how we judge, how we feel. To allude to Wittgenstein: to attend to how we actually talk is also to attend clearsightedly to how we live. The challenge is to 'look and see' (Wittgenstein 1997, \ 66). 'Grammar' is thus not a fixed structure, and is not to be understood in a purely linguistic sense. Solanas' approach reminds us of Wittgenstein's philosophy, in which language use and descriptions of our language use are the way to gaining clarity when a philosophical problem is bothering us. Wittgenstein's emphasis on descriptions (and grammar) is based on a critique of ways in which philosophers have a tendency to offer general theories, overlooking particular cases and examples in their search for theses about reality, knowledge, being or identity. The emphasis on description and language use reflects Wittgenstein's understanding of philosophy as therapeutic. He writes:

And we may not advance any kind of theory. There must not be anything hypothetical in our considerations. We must do away with all explanation, and description alone must take its place. And this description gets its light, that is to say its purpose, from the philosophical problems. These are, of course, not empirical problems; they are solved, rather, by looking into the workings of our language, and that in such a way as to make us recognize those workings: in despite of an urge to misunderstand them (Wittgenstein \$109, 1953/2009: p. 47).

Wittgenstein's emphasis on description is useful in reading The SCUM Manifesto, where we find descriptions that reveal forms of understanding and perspectives on the world: descriptions of the good family girl, the active male or the sissy. Taking Wittgenstein's point further, one could say that in reading Solanas, the challenge is to see what these descriptions can $d o$ - what they tell us. Then we return to the level of impulses, reactions and judgment: we have to let the descriptions work on us. Descriptions of course are never neutral, and in the case of The SCUM Manifesto they express in several ways what it means to be an 'embodied and embedded subject', to paraphrase Rosi Braidotti, or what it means to speak a 'politics of location', to paraphrase Adrienne Rich.

\section{DESCRIBING AND FACING REALITY}

\section{So what kind of work do descriptions do?}

One could say that Solanas portrays the kind of difficulty that Cora Diamond (2008) writes about in her essay The Difficulty of Reality and the Difficulty of Philosophy, but in a very different spirit. ${ }^{9}$ Diamond's essay is about the ways we struggle to find words when faced with aspects of reality that we find incomprehensible. Diamond shows how real-life questions and problems are distorted when they are abstractly reflected upon. One of Diamond's examples in making this argument is a reading of J. M. Coetzee's novel Elizabeth Costello, in which the protagonist is a woman whom Diamond describes as 'haunted by the horror of what we do to animals' (Diamond 2008: 46). Costello is haunted, but also very lonely in seeing what she sees and in experiencing reality as an outrage. The point is she can't come to terms with what she sees around her - the killing and the slaughtering and eating of animals, this mostly ordinary thing we do. Diamond is critical of the idea that our moral existential questions and concerns could be settled through philosophical argumentation, feminist theory, or moral philosophy providing a kind of independent neutral logic that could dictate the meaning things will or should have for us. Rather, she wants to point out, (as we do in our reading of the manifesto) moral meaning is not rooted in theories about what is right or wrong, or questions of how one should live ('is it right to eat meat?'). Such questions and concerns 'are born out of morality [...] born out of the things that matter between us: how we can show love, or pity, or concern, and how we can fail or harm one another' (Nordling 2013: 19, emphasis in original). When reading Solanas' manifesto in this light, one can say that it reveals the roots of feminist critique and criticism, the roots of morality, affects and politics - not only as embedded in our existence and shared lives, but also the ways in which they can all be corrupted.

\footnotetext{
${ }_{9}^{9}$ Diamond's essay concerns ways in which moral and ethical concerns are rooted in our shared, everyday lives and cannot be 'settled' or decided in an abstract, theoretical realm. The essay underlines the fact that the moral philosophical questions often take the form of 'what would you do', or 'what do you think', where the difficulty is precisely in figuring out what one thinks or where one stands. However, there is a difference between Solanas and Diamond in their writing and thinking. Diamond writes about aspects of reality that render us speechless - whereas Solanas' response to 'the difficulty of reality' is to scream (cf. Ronell 2004, 2010).
} 


\section{THE GRAMMAR OF PATRIARCHY}

Solanas introduces us to a world of Men, Daddy's Girls and groovy females subverting the system:

Daddy's Girl, always tense and fearful, uncool, unanalytical, lacking objectivity, appraises Daddy, and thereafter other men, against a background of fear ("respect") and is not only unable to see the empty shell behind the façade, but accepts the definition of himself as superior, as a female, and of herself as inferior, as a male, which thanks to Daddy, she really is (Solanas 2004: 44).

On the surface, Solanas blames men; by nature (or is it quasi-nature?) they are passive, egoistic, parasitic beings who mar the world with their presence. As such beings, men cannot even face their own lack of security. Women are continuously created as bearers of these male characteristics. Men make woman passive, egoistic and dependent - because that is what he himself is, or makes himself to be, but cannot bear to be seen as. It is clear that 'male' is the primary concept, in that 'female' is everything 'male' is supposed to not be. "Being an incomplete female, the male spends his life attempting to complete himself, to become female" (Solanas 2004: 27). She paints a toxic dialectic of two sexes/genders, where the one exists as the dark secret of the other. Female passivity is male passivity, male passivity is a constant process of projecting his passivity onto others, constantly needing to be acknowledged and confirmed as the strong, independent Man. Alluding to this psychoanalytic thematic, Solanas describes how this mirroring leads to hollowness in everybody - to an empty life.

The female's individuality, which he is acutely aware of, but which he doesn't comprehend and isn't capable of relating to or grasping emotionally, frightens and upsets him and fills him with envy. So he denies it in her and proceeds to define everyone in terms of his or her function or use, assigning to himself, of course, the most important functions - doctor, president, scientist - therefore providing himself with an identity, if not individuality, and tries to convince himself and women (he's succeeded best at convincing women) that the female function is to bear and raise children and to relax, comfort and boost the ego of the male: that her function is such as to make her interchangeable with every other female (Solanas 2004: 46-7).

Man and Woman are figurations, expressing different perspectives, abstract models in a sense, not essentialist understandings or descriptions of gender - but descriptions of what essential understandings of gender do with us. In other words: how we turn ourselves into walking and talking essences.

\section{MALENESS, DADDY'S WORLD}

Solanas shows us what it means to understand the world through the concept of 'maleness' and everything entangled with it. Through the perspective of the male everything becomes distorted and infected. The logic of the male is expressed in terms of identity: in writing about Daddy's Girls, and the Great Man, Solanas targets the ways in which the existence of Man is self-deceptive. In his inability to face himself, he projects his own passivity onto women and takes comfort in the identity of being a man. She describes how the male is emotionally crippled, unable to relate to anyone, and only capable of negative feelings. His existence is ridden by guilt, shame, jealousy, contempt and insecurities. He is incapable of relating, he cannot have relations, and philosophically he presents us with universalism: "Unable to give of love or affection, the male gives money" (2004: 41).

The effect of fatherhood on males, specifically, is to make them 'Men', that is, highly defensive of all impulses to passivity, faggotry, and of desires to be female. Every boy wants to imitate his mother, be her, fuse with her, but Daddy forbids this; he is the mother; he gets to fuse with her. So he tells the boy, sometimes directly, sometimes indirectly, to not be a sissy, to act like a 'Man'. The boy, scared shitless of and 'respecting' his father, complies, and becomes just like Daddy, that model of 'Man'-hood, the allAmerican ideal - the well-behaved heterosexual dullard (Solanas 2004: 44).

Solanas shows us the conceptual surrounding of expressions such as 'be a man!' and 'don't be a sissy!'. She presents the muddle of gendered logics: a 'sissy' is taken as a faggot, and the faggot is a faggot because he is a woman, thus not a man. But women have to act like faggots to please and comfort men. Women are faggots, and faggots are women. Men are everything else - everything good, that is. These ways of talking are not only connected to questions of gender. A major point in The SCUM Manifesto is that concepts of gender cannot be isolated. That is why it is so difficult to see where the problems lie. Images of maleness and femininity are tied up in a shared human existence, in which gender is a part - as Nietzsche would say: a poisoning part, a part that turns the entire existence to shit. We have emphasised how Solanas actualises difficulties we face in the context of the everyday 
and our shared lives. Let us now give you an example of this kind of entanglement, and problematique from the context of our own lives - in this case, of a situation in which Sara is playing a board game with her family:

Sara: I am playing a board game with my family (my partner and our two kids) on a nice Saturday evening when we are all gathered together, I lose. No big deal really, but then my four-year-old son looks at me with spite and concludes loudly:

"Mummy lost because she has a pussy, I and Daddy won!"

I freeze.

I’ve brought a monster into this world.

Then I of course try to explain that girls can do the same things as boys, that boys can do the same things as girls, and that it has nothing to do with my pussy that I lost. He nods and says he understands, but I can see in his eyes that he's confused. As if I was claiming that blue is red or that tomorrow is today. Feminist questions do not only concern, in this case, a feminist (me) clinically studying how "socialisation is gendered". In this case it's only about me understanding that my child is learning to despise women.

Feminist theory is sometimes described as a 'tool box' for analysing how different categories (for example, misogyny, homophobia and racism) 'work' in relation to the structures power and oppression. But feminist theory also often leaves us, or the feminist critic, there. We are left with our concepts, our theories and descriptions of power relations but also with the anger and frustration we experience in facing them. Concepts and historicising gestures do not always help us face our anger and frustration. That is why it is so important to acknowledge that there is another aspect to the 'toolbox': our struggles with reality that are existential, personal, our own. In trying to sort out what is at stake here, let us think about the struggles of Elizabeth Costello. There is no struggle with reality when seeing the thing on your plate as food, as a piece of meat, but in describing what is on your plate as a dead animal, a corpse. The board-game example is about the same difficulty. The description expresses that something is wrong: a child is learning to despise women. It expresses fear and triggers memories; I (Sara) become the little girl-parent, unable to throw rocks properly and, of course, losing games. Sometimes, when we have presented this text at a conference, reading this example out loud, people in the audience have started laughing. Maybe they laugh because they pay attention to other aspects of the story ( $\mathrm{I}$ am, after all, describing my child as a monster). After the last sentence they stop. Silence. The room is filled with a sense of tension, awkwardness. They know that instead of food, they have been served a piece of dead cow, and they are left alone to figure out what the hell to do with it.

It is important to note that the connections Solanas draws are not theoretical, but moral and existential, and that the connections are bound up with the question: why the hell do people go on living these lives?

Trained from an early childhood in niceness, politeness and "dignity", in pandering to the male need to disguise his animalism, she obligingly reduces her own "conversation" to small talk, a bland, insipid avoidance of any topic beyond the utterly trivial - or is "educated", to "intellectual" discussion, that is, impersonal discoursing on irrelevant distractions - the Gross National Product, the Common Market, the influence of Rimbaud on symbolist painting. So adept is she at pandering that it eventually becomes second nature and she continues to pander to men even when in the company of other females only (Solanas 2004: 56)

The life of Man is dead. The entire world is trivialised. She depicts a world of endless contempt - not least contempt directed at oneself - hidden under a surface of 'progress', 'respectability' and 'ambition'. Maleness is bound up with rationality, political mastery and sovereignty, and reflected in the practices and discourses of philosophy and arts. Solanas targets ideologies of gender and the ways in which these shape our activities in our everyday lives; these ideologies are no less than life-hating dynamics of fear, contempt and 'dignity'. She especially targets the institutions (money, work, 'leisure', the family, the state etc.) that maintain the Man.

\section{KILLING IDEAS}

In many ways Solanas exposes, challenges and crushes contemporary ideas and ideologies of gender. As every reader of the manifesto knows, she talks about killing men - but she is really talking about killing a certain life form; ideas and ideologies that are poisonous to us - that distance us from reality and create unlivable lives. Solanas reminds us of the importance of eliminating things that make life shallow: e.g., Family, Reproduction, Money, etc. 
She doesn't put faith in development, because she doesn't believe in the society we have. New and 'better' arrangements for Big Daddy and Daddy's Girl are not the answer (cf. Solanas 2004: 76). It is not possible to fix things so that everything eventually will be alright.

Political and philosophical questions sometimes have a kind of awkward grammar. In expecting us to position ourselves and argue for or against a philosophical position or argument, the difficulty of these questions, the forms they often take in our lives, are avoided. Political questions are sometimes characterised by the fact that something has gone too far, and is impossible to restore; situations in which it is impossible to start from scratch. It might be akin to being confronted with a pile of nuclear waste and be expected to have a solution for what to do with it. Or, it is as in the example with the board game and with Costello. Sometimes the description itself does the philosophical work. It brings out a perspective. It is a point of departure for reflection (reflection is also affective), rather than a lifeless object to dissect or deconstruct. The state we are in when common sense, the conventional philosophical 'wisdom' no longer helps us. When philosophy is not love of wisdom, but rather 'combat' and internal struggle (Ronell 2010: 1, 27). The state of feeling unhinged, trying to look around, trying to understand what is conventionally understood as perfectly normal, something that needs no further attention, boys being boys, studying philosophy, normal life. Solanas and the Manifesto remind us of what it means to be unhinged, to lead an impossible life. The existential burden we sometimes experience when we face resistance, or feel the burden of power structures dragging us down, somewhere there in the margins (we scream).

In the lecture Can One Lead a Good Life in a Bad Life, Judith Butler (2012) discusses some of Adorno's remarks on morality. Butler points out that a wrong life cannot be lived right; if one wants to pursue the good life, one must then resist the bad life, and not forget that a good life is a life lived with others. One could say that the same question also bothers Solanas, who resists the destructive aspects of a life under a gendered system or ideology: the image of suburban happiness, of the small family unit having become 'independent'. This is also an important aspect of understanding the need for change, and the need for collapse that is raised within feminist philosophy, activism and academic work. For example, when de Beauvoir wrote her famous words - that one is not born a woman, but one becomes one - it wasn't a description only of the ways in which 'we' are socialised to become 'women'. Her descriptions in The Second Sex of various forms of femininity and the structures of otherness were also descriptions of something that needed to change.

Solanas writes from a tormented place of frustration, particularly in existential terms, of the difficulty and desperation of living in a world where one does not find one's feet. Still, she is familiar with it, she lives in it - it is no mystery to her. Here the similarities with the Adorno of the completely devastated Minima Moralia are striking. They both adapt the language of psychoanalysis for their own ends. Adorno writes:

If the psychoanalytic theory holds, that women perceive their physical constitution [Beschaffenheit] as the consequence of castration, then in their neurosis they intuit the truth. Those who feel themselves to be wounds when they bleed, know more about themselves than those who style themselves as flowers, because that's what their busband likes. The lie is not merely that nature is affirmed, where it is merely tolerated and built in, but that what passes for nature in civilization is according to its substance the most removed from everything natural, the pure turning of oneself into an object. The kind of femininity which calls upon the instincts, is invariably the one to which every woman must compel herself with all manner of violence - with masculine violence: the little women are little men” (Adorno 2005: \59, emphasis added).

Like Solanas, Adorno performs a cultural critique and shows us how personal, cultural, political and philosophical questions cannot be disconnected. Often when trying to make sense of people's different experiences and realities, one is easily led to think that in hurt and damaged descriptions, reality is blurred, less real. Inspired by Adorno, we want to challenge this idea. Adorno's description of the woman who has difficulties feeling like a flower, who feels like an open wound when she bleeds and who is the sane one, reminds us of SCUM. Both Adorno and Solanas have lost faith in humanity (Adorno is writing after the Holocaust). It also reminds us of what's at stake in the board game example that expresses an understanding, a fear, that a child is making Big Daddy's outlook on life his own. It's a sense of losing faith in order to keep the faith. Sometimes alienation, the feeling of losing one's mind, slipping, not being able to make sense of reality when it has become an ongoing nightmare, is a sane reaction (and the opposite would be self-deception?). Also think of Elizabeth Costello: it is hard to enjoy a cozy family dinner when a dead corpse from an industrialised slaughterhouse sits upon one's plate.

\section{'LIFE IS ABSURD' - THE INVENTION OF PHILOSOPHY}

When we first read The SCUM Manifesto, we were thrilled. For all its wounds and desperation, the Manifesto is also a text of revelation, of clarity, of dissipating phenomena that are revered. Instead of resentment, Solanas employs a brutal brand of humour when working with familiar figures of thought and common ways of talking. 
As Ronell states in her preface to the Manifesto: "Wounded and wounding, she comes out shooting, unsnapping all manner of discursive safety nets and cultural supports that have allowed violence to be absorbed." (Ronell 2004: 15). This should not be assigned as mere style; the brutal disclosure is an important dimension of the understanding Solanas offers. Fucking up is not only a matter of provocation - in the Manifesto, fucking up is a matter of survival. Even though the text contains humour, the humour never strays from or alleviates that sense of survival, of trying to imagine a society different from the constant state of being distracted from what truly matters in life. Men are chasing the perfect form of satisfaction, and women desperately try to deliver it to them. In this society we are rendered blasé; a social code is enforced that ensure blandness. Solanas describes a society of polite newspeak that turns baby talk into the language of businessmen and 'great thinkers'. One could say, then, that for Solanas, 'fucking up' is all about gaining clarity and making sense out of nonsense. But clarity is different from what is now lauded as great thinking and great art. On the topics of philosophy and religion Solanas writes:

The male's inability to relate to anybody or anything makes his life pointless and meaningless (the ultimate male insight is that life is absurd), so he invented philosophy and religion. Being empty, he looks outward, not only for guidance and control, but for salvation and for the meaning of life. Happiness being for him impossible on this earth, he invented Heaven (Solanas 2004: 52).

And of (male) philosophers she writes:

So they label the male condition the Human Condition, posit their nothingness problem, which horrifies them, as a philosophical dilemma, thereby giving stature to their animalism, grandiloquently label their nothingness their "Identity Problem", and proceed to prattle on pompously about the "Crisis of the Individual", the "Essence of Being", "Existence preceding Essence", "Existential Modes of Being", etc., etc."

A woman not only takes her identity and individuality for granted, but knows instinctively that the only wrong is to hurt others, and that the meaning of life is love (Solanas 2004: 53).

In Big Daddy-philosophy, Man is alone, he is an Island who 'values' and 'respects' others (who 'deserve' his respect), but can never fully relate or love anything, because he despises himself. As a perspective and as a starting point, this is infective (bad philosophy in bad life). Since Big Daddy turns everything into shit, Solanas cannot make his questions her own. No good philosophy springs from a bad question - 'bad' in the sense of parasitic, blood-sucker philosophy; the kind of thinking that glorifies the image of the rugged individual boldly facing the dread of absurdity and social alienation. Solanas is alone, but not in the same sense that Big Daddy is 'alone'. Again: she dreams of groovy females fucking up. But most importantly, Solanas does not consider 'Philosophical questions' to be real questions, but questions of the narcissistic Male Ego. The 'Identity Problem' is not a problem to her in a philosophical sense. What troubles her is what is expressed in and by the kind of 'Problem' identity is portrayed to be: a world view of self-aggrandisement, fear and the desire to disappear in the warm folds of the collective, while at the same time thinking of oneself as the Heroic Individual. Male philosophy is lonely, in contrast to communities in which thinking is done together with other people in an ongoing conversation and in which one believes that happiness lies outside oneself (cf. Solanas 2004: 53, 66, 75).

Solanas writes about groovy, thrill-seeking females who love instinctually. In a grammatical sense, groovy, thrillseeking females do not find life absurd - if they do, it's not in the same way as the Philosopher finds it. Through Solanas' perspective we see how this form of life of the Great Big Man and Daddy's Girls cannot be endured. Solanas writes:

But SCUM is too impatient to wait for the de-brainwashing of millions of assholes. Why should the swinging females continue to plod dismally along with the dull male ones? Why should the fates of the groovy and the creepy be intertwined? Why should the active and imaginative consult the passive and dull on social policy? Why should the independent be confined to the sewer along with the dependent who need Daddy to cling to? (2004: 71).

Here, Solanas can be and has been read as articulating a radical feminist viewpoint, questioning the culture that teaches women to please and serve others. Similarly as for de Beauvoir, what is at stake is freedom. 


\section{IS SOLANAS A PHILOSOPHER?}

As mentioned earlier, few have read Solanas as a philosopher. Is she one?

Solanas in many ways addresses central questions in feminist philosophy. The SCUM Manifesto is a critique of institutions, of authority. And Solanas is impatient. She doesn't have time or patience for philosophy. So, what becomes of the philosopher in Solanas? Examining this issue we might get a glimpse of how questions about what is philosophy and what is not become political, questions of ideology. First, it is clear that Solanas despises 'Philosophers'. She talks about 'them', refusing the term 'us' and this should be respected. She is also not a 'feminist'. That too should be respected. Why this refusal? Solanas is quite clear about the fact that the liberal feminists are wrong.

'Daddy's Girls' have no place in the new world order she envisions. What Solanas brings to the forefront is that to argue or debate about 'Philosophy' or 'Art' is to miss the point. These are all activities related to values of the Great Man. Art cannot be considered without its gendered nature; philosophy is a male activity, one of selfdeception reflecting the existence of constant lack in the male (Solanas, as we have seen, reverses the psychoanalytic account of woman as lack). But Solanas doesn't talk about lack here to advance a 'theory of the subject'. She talks about hollowness: life is squeezed out of us by living in a male world. Bad faith (Sartre - the overrated windbag) ${ }^{10}$ could be another term. It is evident that she despises identity and destructive forms of belonging and collectivity.

Identity is destructive when we cling on, to belong to something, instead of facing our own lives. There is comfort in the convenience of being one of the guys/girls/moms/Finns. The power and the dangers of collectivity, and identity within it, is shown in the failures of belonging, in exclusion or alienation. Solanas suggests alienation as a way out, together with thrill-seeking females who loot the system.

Not making 'Philosophical problems' her own is a political statement, but also a comment on the patriarchal grammar of 'Philosophy': 'Philosophy' is not made by groovy females, clowns or prostitutes - subjects whom the Philosopher's rumination does not even take into account.

So when thinking about whether Solanas should be considered a philosopher or not, the question is not only about Solanas. It is also about what kind of questions one finds important. Sometimes they are political ones. For Solanas, gender - being male or female - is a way of losing one's individuality, being reduced to an identity (a walking essence $)^{11}$. This could also be interpreted as taking refuge in norms, fleeing into collective forms of being (Heideggerian herd mentality). But questions of morality, and of taking a moral stance, cannot be collective. These are issues one has to figure out for oneself.

To conclude our discussion of Solanas and philosophy, we want to consider an example that Avital Ronell (2010) gives us about her coming to philosophy. The example serves here as a contrast we wish to illuminate, between different perspectives on the power of normativity within academia, and the desire for radicalism that spurs so many critical thinkers.

\section{CONCLUSION: MISFITS, SOLANAS, RONELL \& GADAMER}

In thinking about the problem of 'others' in philosophy, or what is sometimes called 'the woman problem in philosophy', as one of the outsiders within, an example is perhaps useful. Avital Ronell (2010: 27) talks about her coming to philosophy through giving an account of when she attended a colloquium in Heidelberg as something of a rogue: a young, punk, critical philosopher who boozed with Gadamer, already an older man, and how they behaved as misfits, 'we almost danced on the tables', behaving 'scandalously'. Later however, when they take a walk, Gadamer encourages the 25-year-old Avital to seek out a master:

We kept on walking and he said: 'You know Avital, to be a real thinker one day, you have to find a master. There is no other way, no possible route. You have to attach yourself to a master and do the painful work of apprenticeship. To go on otherwise is an illusion, and it isn't real philosophical work.' (Ronell 2010: 27)

Of course Avital is revolted by his words, but ... she goes to France and studies with Derrida for two years, indeed finding a master. Ronell speaks of feeling misplaced in philosophy and searching for place in unconventional spaces and dark alleys. She too finds traces of philosophy in Solanas. However, the question remains why the figure

\footnotetext{
${ }^{10}$ Solanas called de Beauvoir and Sartre overrated windbags - another example of how she views philosophy and philosophers (Heller 2001, quoted in Ronell 2004: 6).

${ }^{11}$ Here it is important to note that when Solanas writes about gender as male or female, she is describing how a particular gendered logic works; this should not be read as endorsing a binary understanding of gender (excluding non-binary gender identification for example).
} 
of a 'Master' is so pertinent? What if the Master doesn't want what is best for one? Must one be trained in misogyny in order to recognise and criticise it? What a waste of time!

Of course, if we take the example further and imagine being a young woman and a misfit and attending a colloquium on philosophy in Heidelberg where nobody spoke to you, or wanted to drink with you or talk philosophy with you, where you would not be one of them, or even part of the cool outcasts, the example becomes something different. Philosophy that emphasises conversation and dialogue suddenly becomes something else. When all there is, is silence. This is an example where the destructiveness of institutionalised philosophy, its inbuilt hierarchies and forms of violence really show, and where the outcome is not 'productive'. There is a certain coolness and romanticised picture of philosophical dialogue in Ronell's example. Who would not want to drink with Gadamer; and, after all, she studied and taught with Derrida. But it also reminds us that for Solanas thinking like this isn't an option, or perhaps her perspective mocks discussions of choice or option. As we said: for her, it's about trying to survive in a patriarchal society. Solanas doesn't put herself in a position where the philosopher can refuse her. She values herself and her life more than that.

In the article Out of Bounds: Philosophy in an Age of Transition, Judith Butler and Rosi Braidotti (2010) write about their experiences of coming to philosophy, a discipline that in many ways has resisted (women) and critical theories. They write about how being critical thinkers and philosophers meant asking questions such as:

how to connect the practice of thinking to larger social and ethical concerns and how to resist the negative and oppressive forces of the present [...] what philosophy is all about and how it can help us lead politically useful, socially productive and morally adequate lives? (Butler \& Braidotti 2010: 310).

Solanas, Butler and Adorno are all aware of the difficulties that might arise when exploring philosophical questions of 'the good life'. 'The good life' that Solanas shows us is wrapped up in ideology - money, health and success that shapes our contemporary culture through a western and patriarchal ideology that has gained the status of being 'good in itself. Solanas' approach to ideology is interesting, since the danger of ideology is described in her understanding of 'life' ('an utter bore').

In revealing 'the grammar of patriarchy' through a description of the corruptness of gender as identity, Solanas describes a world of ordinary and normalised violence that takes the form of institutions (money, the government) and ideas about the good life (decency, compliance, 'the male outsider'). She spells out the connections between gender, identity, destruction and maleness. The Manifesto focuses on the urgency we sometimes feel when faced with moral, political and existential difficulties. Performing a cultural critique of her own, Solanas reveals the corruptness of gender relations. She shows us how what seems perfectly ordinary and good (a comfortable family life, a busy job, intellectual pursuits like Art or Philosophy) is actually deeply troubling. In a sense, Solanas' Manifesto doesn't engage with theory, epistemology or ontology at all. Thinking about the text in relation to the theme of this issue, one could say that the question of 'epistemic habits' does not concern Solanas at all. She is not within that discourse - she doesn't care. What she cares about is no less than a life of love and compassion.

Both Butler (2012) and Solanas remind us that life both is and is not one's own. This is where Solanas, although something of an anti-social philosopher, becomes liberating. In presenting us with fuck-up crews and groovy females she also reminds us that sometimes dropping out is not the answer: fucking up is. Most women have already dropped out; they were never in.

In her Manifesto, we claim, Solanas examines the patriarchal grammar of Life, where Big Daddy clings to a pair of tits and Daddy's Girl clings to Big Daddy - a life that Solanas rejects, describing it as shallow and self-deceptive. This exclusion works on many levels; being true to oneself might be the only way to go, but it is also a lonely path. Feeling the burden of a grim society. She still wants to lead a meaningful life. Solanas challenges normative and damaging ideas: for her, critique is not about coming up with new concepts. When Big Daddy makes money and finds it important to reproduce (live forever?), Solanas says that the meaning of life is love. Or that it should be, and that something has to change. Ronell describes Solanas' style and voice as a scream - a scream that cuts through. By rejecting the patriarchal grammar, Solanas makes new spaces, or simply cracks, where we can talk about what's really important. In her own way, Solanas shows us what a desire for change looks like and how a desire for change in one's own life is bound up with change in other people's lives and attitudes. Screaming is an acute call for change, and it is in this spirit that we find the value of feminist critique, in a life that both is and is not one's own. 


\section{REFERENCES}

Adorno T. (1951/2005). Minima Moralia: Reflections from a Damaged Life. New York: Verso.

Anderson, A. (2006). The Way We Argue Now. A Study in the Cultures of Theory. New Jersey: Princeton University Press.

Butler, J. (2012). Can one lead a good life in a bad life? Journal of Radical Pbilosophy, (176)9, pp. 9-18.

Braidotti, R. and Butler, J. (2013). Out of bounds: Philosophy in an age of transition. In: R. Braidotti, ed., The History of Continental Pbilosophy Volume 7 - After Poststructuralism: Transitionsand Transformations (pp. 307-335). Durham: Acumen.

Diamond, C. (2008). The difficulty of philosophy and the difficulty of reality. In: S. Cavell, C. Diamond, J. McDowell, I. Hacking and C. Wolfe., eds., Philosophy and Animal Life. (pp. 43-90) New York: Columbia University Press.

Fahs, B. (2008). The Radical Possibilities of Valerie Solanas. Feminist Studies, 34(3), pp. 591-617.

Fahs. B (2014). The Defiant Life of the Woman Who Wrote SCUM (and shot Andy Warbol). New York: The Feminist Press at the City of New York University.

Fahs, B. (2016). Spitfire and sass: Valerie Solanas's “A Young Girl's Primer" and the creative possibilities of a survival self. WSQ: Women's Studies Quarterly, 44(1-2), pp. 255-267.

Felski, R. (2015). The Limits of Critique. Chicago and London: University of Chicago Press.

Felski, R. and Anker, S. (2017) Introduction. In: R. Felski and S. Anker, eds., Critique and Postcritique (pp.1-28). Durham and London: Duke University Press.

Love, H. (2014). Doing Being Deviant: Deviance studies, Description and the Queer Ordinary. Differences: A Journal of Feminist Cultural Studies, (26)1, pp. 74-95.

Love, H., Best, S. and Marcus, S. (2016) Building a better description. Representations, (13), pp. 1-21.

McBean, S. (2016). The feminist manifesto. Valerie Solanas and SCUM. In: S. McBean, Feminism's Queer Potentialities (pp.97-121). New York and London: Routledge.

Moi, T. (2009). They Practice Their Trades in Different Worlds. New Literary History, (40)4, pp. 801-834.

Moi, T. (2017). The Revolution of the Ordinary. Chicago and London: University of Chicago Press.

Nordling, B. (2013). Describing a Revolution. The Pbilosopby of Animal Ethics, unpublished MA thesis in Philosophy, Åbo: Åbo Akademi University.

Ronell, A. (2004). The deviant payback: The aims of Valerie Solanas, Introduction. In: V. Solanas, ed., The SCUM Manifesto (pp. 1-34). New York and London: Verso Books.

Ronell, A. (2010). Fighting Theory. Avital Ronell in Conversation with Anne Dufourmantelle. Urbana, Chicago and Springfield: University of Illinois Press.

Rowe, D.D. (2011). I Should've Done Target Practice: Why Valerie Solanas Missed. Qualitative Inquiry, (17)2, pp. 130-133.

Rowe, D.D. (2013). The (dis)appearance of Up Your Ass: Valerie Solanas as abject revolutionary. Rethinking History: A Journal of Theory and Practice, (17)1, pp. 74-81.

Rowe, D.D. (2014). Performative (re)Writing: Performative writing and the politics of scribble. Women and Language, (36)2, pp. 107-113.

Sedgwick, E.K. (2003). Touching Feeling: Affect, Pedagogy, Performativity. Durham: Duke University Press.

Rosenberg, R. (2010). Still Angry After All These Years or Valerie Solanas Under Your Skin. Theatre Journal, (62)4, pp. 529-534.

Solanas, V. (2004). The SCUM Manifesto. New York \& London: Verso Books.

Third, A. (2006). 'Shooting from the hip': Valerie Solanas, SCUM and the apocalyptic politics of radical feminism. Hecate: An Interdisciplinary Journal of Women's Liberation, 32(2), pp. 104-132.

Wittgenstein, L. (1997). Philosophical Investigations, transl. G.E.M Anscombe. Oxford: Blackwell.

Citation: Peltonen, S., Lindman, M. and Nyman, S. (2017). Perceiving Shit as Shit: On the Grammar of Patriarchy in Solanas' SCUM Manifesto. Feminist Encounters: A Journal of Critical Studies in Culture and Politics, 1(1), 09. https://doi.org/10.20897/femenc.201709

Copyright (C) 2017 by Author/s and Licensed by Lectito BV, Netherlands. This is an open access article distributed under the Creative Commons Attribution License which permits unrestricted use, distribution, and reproduction in any medium, provided the original work is properly cited. 


\title{
INTERVIEW
}

\section{Assessing Critique, Scholarly 'Habits', Queer Method and 'Turns': An Interview with Heather Love}

\author{
Heather Love ${ }^{1 *}$, Salla Peltonen ${ }^{2}$
}

Published: October 30, 2017

\begin{abstract}
The interview considers the role of critique and epistemic habits within the fields of feminist, gender and queer studies. It addresses the collective, scholarly, activist and personal stakes in doing critical academic work as well as the politics of knowledge production. Assessing the role that the institutions have in producing critical knowledge it also discusses questions of method, description and 'turns' as well as material and social conditions of academic work.
\end{abstract}

Keywords: epistemic habits, critique, postcritique, queer method, description

\section{THE INTERVIEW}

Salla: How do you understand and assess the current discussions on critique and postcritique?

Heather: Because I've been working between the humanities and the social sciences I am interested in how a general questioning or rethinking of critique is happening across a bunch of fields simultaneously. There are critical ways to see that. You can see it as an effect of neoliberalism or as political despair, or as a reflection of the economic conditions of the contemporary university. I keep that explanation in mind, I suppose, as a critical, suspicious or paranoid account of what is going on. But it is possible to access other modes of thinking about our objects and even about power and domination without seeing them only within the frame of critique. People are trying to open up new modes of thinking. I want to keep a critical framework in mind but also resist the idea that post-critique is just cynical or professional or an epiphenomenon of neoliberalism.

Many areas of scholarly research can be revalued or transformed by branching out into different relations to critique. Bruno Latour is a really interesting example. He is one of the key architects of social construction in the sciences although he has distanced himself from that position now. I have in mind for example how in his Critical Inquiry piece "Why Has Critique Run Out of Steam?" he moves from a theory of the construction of facts in the sense of making them up to a more positive account of how the world is made, how it works. I think you can see those kinds of transitions in several domains. I don't have a great explanation for why this is happening, but it has opened a lot of new perspectives for me.

This moment reminds me of my own transition from a poststructuralist and psychoanalytic training to work on affect. I had learned to think about the subject in a very particular way, but was excited to discover other frameworks for thinking about psychic experience, embodiment, and feeling that were actually more descriptive and more capacious. I saw that as an opportunity because a lot of the material I was working with (on queer historical emotion) wasn't that amenable to a Freudian or Lacanian account.

Salla: What do you think these discussions are symptomatic of? Do you think it is a symptom of a craving for intellectual freedom on the one hand and wanting to think beyond the frames of our epistemic habits, or are the debates also a question of how we identify or position and identify ourselves as 'critics'? 
Heather: I tend to think of critics as constrained by their situation, their discursive community. I began by talking big about the global economy but we could also just talk about disciplines and academic departments. An example that I always return to is Bourdieu's account of skbole, or the scholastic orientation-the idea that you see the world from a library desk. I think the overvaluation of language, vis-a-vis other frameworks or domains of representation or experience, has to do with the fact that, as critics and writers, that we tend to value withdrawal rather than worldliness.

To address the significance of the university or even the profession as a framework for what we do is not only to write it off. I think we have a tendency to see scholars as more constrained than enabled by the dictates of academic scholarship. But I am not all that invested in the radical freedom that is blocked by the academy because, honestly, I am not sure would have ever written anything if it hadn't been for the profession. The structure and the sense of a broader conversation and history have all been very enabling for me. But I do think that a zone of freedom can open by bringing in something that doesn't really fit into that framework. I wrote a little piece for the Women's Review of Books a long time ago about Judith Butler, when Sarah Salih's edited reader came out. I cited that great moment from Undoing Gender in which she writes, 'the only way to describe me in my younger years was as a bar dyke who spent her days reading Hegel and her evenings, well, at the gay bar'. I see this attempt to reconcile discordant experiences and discourses as really generative-for Butler, for queer studies, and more generally.

I get excited when critics use personal experience in their work, because of the way it breaks the rules of academic discourse. I'm more interested in this as a discursive event than I am interested, necessarily, in the content of that experience (though sometimes I am pretty interested in that as well...). I have tried to use some autobiographical moments in my writing in order to mess with the conventions of academic writing — to create some intellectual and emotional space. It's not a practice of unfettered freedom but a kind of friction or tension that I find generative, I suppose.

I think that this interest partly explains my attraction to the bizarrely detailed micro-analytical accounts of everyday life that I have been working on most recently. These projects really don't fit in the frame of my training, and it's the wrenching of perspectives and the challenge that I find interesting. Even though these social science accounts are the opposite of more visceral or personal feminist or queer writing, they get me excited in similar ways because of the breaking of frames of standard modes of scholarship and writing.

Salla: What do you think of the state of academic critique formulated as different 'turns'? I am thinking about what critique does in these turns, what is at stake in formulating different turns as critical interventions? What do you think about this in relation to for example the descriptive turn?

Heather: I feel like you are asking me a structural or a formal question about how fields change. If it's about how the critique and post-critique debate played out in affect studies vs. queer studies, I could formulate a narrative specifically about that, somewhat partial and impressionistic — but it seems to be a more general question

The American Studies scholar Mark Seltzer has a critique of what he calls the turn turn. He asks why every academic article seems to be part of one turn or another, and he contextualises this fact in terms of the hyper reflexivity of second modernity (Ulrich Beck). It's a complex concept, related to the rise of cybernetics, the expansion of media, etc., which results in constant self-reflection and recording. So what's the point of thinking a thought if it can't also be registered as part of a larger process?

And why is it a turn? What is it about the idea of a turn? It has the progressivist associations of turning a new corner, turning over a new leaf, it's all about greet the new. But of course turning can also be about going nowhere fast. ${ }^{1}$ I don't think it can be separated from the commodification of knowledge and the fetishisation of novelty that is so fundamental to the discipline. How do you get ahead? It is by coining terms or shifting paradigms, or whatever.

Salla: Would you say those are epistemic habits of our fields?

Heather: I suppose I would frame epistemic habits in terms of the material underpinnings of university work. It has been interesting to work on the question of description at this moment. I am looking at all of these experiments, projects of complete description that were very time-consuming and that had very low stakes. So I am exploring the lowest thresholds of utility and interest and drama in scholarly work-and yet I find this stuff fascinating and beautiful. But in terms of my daily life, I spend so much of my time as an academic advisor,

\footnotetext{
${ }^{1}$ For this sense of turning (as well as another account of second modernity) see Justin Vivian Bond's mash-up of "Total Eclipse of the Heart" (“Turn around, bright eyes!”) with “Turn! Turn! Turn!", ("You Turn Me On, I'm a Radio)" and "Slouching Toward Bethlehem" ("Turning and turning in the widening gyre"). https://www.youtube.com/watch?v =oVpIZChta8
} 
encouraging $\mathrm{PhD}$ students to frame their scholarship in terms of bigger stakes, trying to help them get attention for their work in an economy of scarcity.

Salla: This is really an important question; I guess it is a question between the rhetoric of the critic and actually doing critical work.

\section{Heather: What do you mean critical work though?}

Salla: Feminist and queer studies have always been in the position of being against the institutions. In academic disciplines that understand themselves as doing a certain kind of critical work, critique gets routinised, and specific forms of critical thinking in a way become sedimented. Other frameworks of 'critique' might not be as easily recognised.

Heather: Yes, sure. But I don't agree with how earlier you characterised different forms of knowledge as mutually exclusive. There is no doubt to me that my deepest training in psychoanalysis and poststructuralism informs the work that I am doing now. This is a good aspect of the idea of a 'turn' because it implies continuity as well as transformation. I sometimes think about these changes is terms of drift. I feel like I drifted into affect studies-I mean it's not always intentional, it's hard to explain these motivations, sometimes you are just following instincts or looking for openings where you can find them. But I also worry about drifting too far out. There is a problem of generations and training: you try to learn what the person who trains you knows, but you can never read everything that they read. For example in the beginning of college I was reading a ton of Derrida without having read Husserl or Heidegger. This is one concern I have about the fetish of novelty, because you are so caught up in what is happening in a particular moment (and the late ' 80 s for deconstruction were really exciting) but then there is always so much to know and think about. If you are in the mode of perpetual critique, you can be really in the moment but actually have no idea what is going on. It's spicy, but you are like-where's the beef? This is what I try to balance in my role as teacher-because knowledge moves fast but also really slow, and it's hard to learn without recognising that.

I see my work on description and the social sciences in a dialectical relationship with deconstruction; it is very loving toward that body of thought. It's like, if you really pay attention to the work of those scholars then it should make you permanently tortured in regard to some fundamental questions (about representation and reality, about the primacy of language). Those are the questions I am asking now (but in a different idiom). I was deeply influenced by Barbara Johnson's work, for instance on persons and things, and by Eve Kosofsky Sedgwick's late engagements with Buddhism and Melanie Klein. It's been useful for me to think about their careers, about the dynamism of their thought over time.

In teaching, you pass on a particular method or mode, but what you really want to pass on is a historical sense or curiosity. Of course in a feminist context or in the context of 'subjugated knowledges' more broadly, the question of citation is essential. But cultivating and modeling a certain relation or orientation to the past is method.

Salla: My next question is about the energy of activist thought that is present in queer studies and often transforms into institutional forms of knowledge. The energy is often described as inspiration, but also as appropriation. Is there any another way of thinking about these kind of knowledge processes than through or as appropriation?

Heather: Because I've been in these kinds of feminist and queer communities my entire adult life, I've seen these fights played out so many times. I can be hurt by the polemics, but I am always interested. People often try to point out the complexity of the question - it's really not either/or, and lots of people are both academics and activists, or teachers and activists. I admire people who work effectively in both modes.

One of the places where this played out, and I wrote about this a little bit at the end of Feeling Backward, was at the controversial Gay Shame at the University of Michigan. There were many tough issues at the conference, but one of the things that interested me was a confrontation between members of the San Francisco anti-gentrification group Gay Shame and the academics in the audience. It was a tricky situation, with real concerns about appropriation (even of the name of the conference). Most of the invited speakers were known as academics, but they were also like, look, we're in this together, we are also doing activism. But I felt that the conflict that emerged was really about the material and economic conditions of activists and freelance artists versus professors, many of them tenured. When the topic is the politics of real estate, or the rights we have in our intellectual property, things get real very quickly. I felt that this conflict about queer radicalism and the academy v. activism was at its heart about economics and social class. I have a lot of ambivalence about the discussion of precarity by U.S. academics. Of course there are a lot of precarious people labouring in universities, but I am very aware of how tenure has 
made my life less precarious than the lives of almost anyone I know. I think acknowledgement of that lack of precarity is as important as acknowledgement of solidarity around shared precarity (which is more common).

Salla: How does your work on description relate to questions about accountability? I am thinking about the difference between engaging with works of art, novels and so and engaging with people.

Heather: I guess my modest proposal is for a lifetime of torment as people try to work out the relationship between theory and practice, or understand their job and its relationship to social change. I guess I am for mental torment, actually. I mean, I know that guilt has its limits as a political emotion-that it can be paralysing, selfserving, etc. But let's just think about the alternative: not being guilty. That's not so great either. I think the important thing is to take into account our position-I mean that in the sense of an intellectual and political orientation, and in terms of material and social relations. For me, becoming an academic felt like an incredible stroke of luck. But the longer I go on my thinking about accountability becomes and more complicated. I certainly don't think I have worked this out-but I did at a certain point become really uncomfortable with rhetorical solutions to material problems. I am talking about the uplifting endings of Left academic essays, that offer a sense of possibility in the face of injustice and horror. The idea is that it is important to be able to imagine change that is not yet possible in our world, and I understand that. It is so deeply tied to aesthetic experience, which is why I am here in the first place, so of course I understand that also. But at a certain point I burned out on it, started to mistrust my ability to provide that kind of consolation in language-because honestly, it costs me nothing. It's out of my sense of a political and really, for me, an emotional and ethical dead end that I've been interested in thinking through new modes of writing and thinking.

Salla: You have written about the messiness of everyday life. What happens with critique if we shift our attention from ideology and system critique and the kind of 'big claims' into messiness of everyday life? They are interrelated, of course, but what are the stakes for you or queer studies in focusing our attention more on the details, the particular cases, the everyday?

Heather: The normativity issue has incited a serious crisis in the field. One definition of queer studies is that it is activist because it is critical. Antihomophobic inquiry - it is not like other scholarly fields, it's not about knowledge production but rather oriented primarily to social transformation.

The entire field turns on that paradox, and how to be an academic discipline whose job it is to change the world. That contradiction structures all of our discourse no matter what position we take on these questions. Part of why I am interested in the queer ordinary or the messiness of everyday life is because I think contemplating the real complexity of actual situations is an important challenge to theory. If politics could proceed according to a blueprint then we would have fixed the world by now. The danger of leading with mess is that you will not get to politics, you will just be lost in the details-muddling through, but never getting anywhere. I think that is a legitimate fear, but nonetheless I've become very interested in this approach.

Salla: Would you say getting lost in the detail is a fear of getting depoliticised?

\section{Heather: Yes}

Salla: Not everything is about politics and thinking about ethics beyond the frameworks of accountability seems difficult. Your work, I think, is an example that we can do something else, that one can move beyond given frameworks and that there is an ethics to being a gender or queer studies scholar doing critique in reading a novel (or working with another kind of object) and having something to say about it.

Heather: I am not saying that I want to carve out a zone that is separate from politics so much as that I want to approach politics in a different way: via the minor, and the particular, and the everyday. But if I wanted to do work that was apolitical, that route is open to me through a more straight-up literary studies (my primary field of training). But despite some frustrations and disappointments and hurt feelings, I am still in the field of queer studies - the horizon of politics is still the ultimate horizon for me. But I want to be able to take the long way around — or I feel that the long way is the only way.

One way to make this more concrete is around the question of social class. I've been trying to argue recently that we need to engage more with descriptions of working class culture. Again, because of how I was trained (and my indebtedness to Marxist thinking), there is a tendency to think about class as a structure rather than an experience. And again, given the class make-up of the profession and the university, it feels like a productive wrenching of frames to even talk about non-elite ways of life in academia. Of course there is a precedent in cultural 
studies, African-American studies, and ethnic studies, but queer studies has a way to go on this front I think (not to mention English departments).

Salla: It's a point about the multiplicity of all kinds of political work: one of the huge epistemic habits is to say what one can and can't do with a certain framework, and then to question it.

Heather: The other thing I would like to mention in this context the habit of polemic. That's a habit that we are all trapped in, like every discussion turns into a pitched battle.

Salla: Queer studies often is characterised as not having a subject or an object. It only has X? Would you like to fill in the $\mathrm{X}$ ? Not as a definition, but giving it content, maybe as a description?

Heather: Well, I would probably just refer to Sedgwick's universalising/minoritising discussion—we all go back to it because it's fucking smart and true. But I am also attracted to other ways of thinking about this question through my work on the history of queer and deviance studies, and also the social science legacy of sexuality studies. I guess even though my own work is about representation and language, and pretty skeptical about identity, I think we make a big mistake by underestimating the value or complexity of empirical work. And in a moment of the queering of everything, I think grounded work on sexual communities and practices is very important. Being in conversation over the past several years with scholars like Gayle Rubin, Roderick Ferguson, and Cindy Patton has helped me to think about these histories, and also about the importance of cultivating respect for scholars (and people) with epistemic habits unlike our own. It's a basic point, but it bears repeating.

\section{REFERENCES}

Butler, J. (2004). Undoing Gender. London and New York: Routledge.

Latour, B. (2004). Why Has Critique Run out of Steam? From Matters of Fact to Matters of Concern. Critical Inquiry, 30(2), pp. 225-248.

Love, H. (2007). Feeling Backward: Loss and the Politics of Queer History. Cambridge, Massachusetts: Harvard University Press.

Salih, S. (ed.) (2004). The Judith Butler Reader. New York: Wiley-Blackwell.

\section{FURTHER READING}

Bourdieu, P. (1990). The Scholastic Point of View. Cultural Anthropology, 5(4), pp. 380-391.

Johnson, B. (2010). Persons and Things. Cambridge, MA: Harvard University Press.

Love, H. (2010). Close But Not Deep: Literary Ethics and the Descriptive Turn. New Literary History, (41)2, pp. 371-391.

Sedgwick, E.K. (1990). Epistemology of the Closet. Berkeley, CA: University of California Press.

Sedgwick, E.K. (2003). Touching Feeling: Affect, Pedagogy, Performativity. Durham, NC: Duke University Press.

Seltzer, M. (2016). The Official World. Durham, NC: Duke University Press.

Stryker, S. (2006). (De)Subjugated Knowledges: An Introduction to Transgender Studies. In: S. Stryker and S. Whittle, eds., The Transgender Studies Reader (pp. 1-17). New York: Routledge.

Citation: Love, H. and Peltonen, S. (2017). Assessing Critique, Scholarly 'Habits', Queer Method and 'Turns': An Interview with Heather Love. Feminist Encounters: A Journal of Critical Studies in Culture and Politics, 1(1), 10. https://doi.org/10.20897/femenc.201710

Copyright (C) 2017 by Author/s and Licensed by Lectito BV, Netherlands. This is an open access article distributed under the Creative Commons Attribution License which permits unrestricted use, distribution, and reproduction in any medium, provided the original work is properly cited. 
http://www.lectitopublishing.nl

https://www.facebook.com/LectitoJournals/

https://twitter.com/lectitojournals

$\mathcal{S}_{+}$https://plus.google.com/110901545130385419486

in https://www.linkedin.com/in/lectito-journals9a675010b/ 


\title{
INTERVIEW
}

\section{Investigating Desires, Political Projects and Epistemic Habits in Academic Feminism: A Conversation with Robyn Wiegman}

\author{
Robyn Wiegman ${ }^{1 *}$, Salla Peltonen ${ }^{2}$
}

Published: October 30, 2017

\begin{abstract}
The interview discusses the stakes in current debates regarding critique and addresses the challenges and the impasses that characterise our political present. The interview also explores questions concerning queer method, critical reading practices and the desires and political projects that have motivated feminist academic work.
\end{abstract}

Keywords: critique, epistemic habits, queer theory, method, postcritique

\section{THE INTERVIEW}

Salla: How do you see and understand the current discussions on critique within the field of gender studies and queer theory?

Robyn: It's not always easy to separate the conversation about critique in gender studies and queer theory from the larger academic conversation in which the 'critique of critique' currently circulates. This larger conversation tends to emphasise the value of the humanities and its orientation toward the study of culture in ways that don't fully jive with the field's distinctly left political intentions. For scholars like Rita Felski, the humanities undercuts itself by not being able to forge a positive relationship to its various objects of study, with the literary being at the heart of her concerns. Her suspicion of suspicious reading arises, in part, because of the way the critic's relationship to the literary object has been coded as naïve if it aligns more with love, affection, or desire than with reprimand, intervention, or disagreement. In this concern for the affects that shape criticism, Felski's argument sounds a lot like Eve Kosofsky Sedgwick's early take on paranoid reading but the contexts that prompted them are quite different. Sedgwick was writing against the paranoia that AIDS had unleashed in order to make space for work that could nurture and repair broken worlds. While she thought that the suspicious mode engendered highly predictable criticism, she was not out to defend the literary object nor did she think that critique was exhausted or self-defeating. She wanted other methodological and affective options for the political work of antihomophobic criticism. Many of the endeavors that have emerged to counter critique are staked to an ethics of reading more so than the political commitments of left criticism. Both are valuable but they are not the same project.

Salla: These endeavours go by various names: surface reading, slow reading, distance reading, weak description. Do you favour one over the other, or do you find the arguments in defence of critique to be most convincing, especially for the work we do in women's, gender and queer studies?

Robyn: In some ways, I find the very proliferation of options to be more interesting than the options themselves, though if pressed I guess I would want to forge my own synthesis, something that emphasises description - but I don't want it to be weak - and slowness, given that both of these require careful reading and a certain suspension of the critic's authority. At the same time, as you might guess, I'm attracted to scholars who resist the lure to proclaim 'the new', especially Elizabeth Weed and Ellen Rooney, both of whom defend the political value of critique by giving us a different account of the history and critical force of symptomatic reading. 
Their counter-arguments illuminate the way the debate has covertly pitted theory against literature and ascribed too much agency to theory in the decline of the humanities in the last forty years. Nevertheless, I think it is a problem to cast the debate in strictly oppositional terms, as if one must be 'for' or 'against' critique, 'for' or 'against' surface reading. What interests me the most right now is how best to understand why critique has become the central figure in debates about critical practice and academic authority: what is being sought? What gets displaced? What are the fault lines in these conversations?

\section{Salla: So you're suspicious about the suspicion over critique?}

Robyn: I guess so! But only to the extent that I think there's something to learn about why the debate has emerged now and what its implications are for the work of gender and queer studies - or any left academic project for that matter. That's why I'm less interested in pledging allegiance to one of the many projects that take aim at critique on behalf of literary objects and the institutional status of the humanities than I am in cultivating resources to understand the relationship between critique and the conditions of our political present. In Object Lessons, I was trying to parse the utility and limit of critique for identity knowledges as a whole, but not in the name of a new mode of criticism. My main concern was the insatiability of the political desire that underwrote scholarship in gender, women, queer, ethnic, and American Studies, and what it means when a field begins to view the objects, concepts, or methods that once defined it as the source of political betrayal. I would go further today and talk about the aggression that gets masked in identity knowledges by our various attempts to find objects we not only can love but love unambivalently, and how the disavowal of aggression is sustained through a highly moralised discourse of political radicality.

Salla: And what about the relationship between critique and the political present? Some critics argue that it is best to describe our current moment as 'post critique'.

Robyn: The concept of 'post-critique' seems to mean different things to different people. For some, it marks the decline of critique's allure in favour of other critical modes, typically those that choose love over suspicion, as I've mentioned, or hope and optimism over negativity. For others - and I would count myself here - it describes the political impasse of the present. In her recently published book Neocitizenship: Political Culture after Democracy, Eva Cherniavsky argues compellingly that the conditions in which critique had political traction have largely disappeared under neoliberalism, as the tenuous compact between the nation and the state has fractured, corporations have become persons, and the citizen has been refashioned as a self-maximising entity whose consent to be governed is no longer cultivated by those in power. For Cherniavsky, this is because the neoliberal state is not a hegemonic formation in the Gramscian sense. The Trump administration is a case in point, as its address is aimed only at its base and not at a broader constituency of 'the people'. I think Cherniavsky is absolutely right in that the hegemonic refers to a different historical moment about the relation between the market and the state. Contemporary political culture is a post-critique culture. This raises the question: what are the rhetorical strategies and forms of analysis that the present moment requires? In an era when knowledge has given way to alternative facts and post-truth - or what my friend and former colleague Purnima Bose calls the new Dark Ages - there is no easy answer to this question.

Salla: You talk about the relationship between knowledge and political action in your exchange with Tim Dean on critique in ELN. You talk about the loss of faith in the belief that knowledge is the means for knowing what to do. Do you think that what we see now is a kind of hangover from that insight? There was a belief that the knowledge produced in women's, gender and queer studies could do stuff, cause social transformation. Is what we are now witnessing not only a crisis of legitimacy but a theoretical and methodological crisis that is bound up with how to understand the relationship between knowledge and (political) action?

Robyn: Critique in these fields has always banked politically on the idea that no matter how sophisticated we might become theoretically, raising people's consciousnesses through knowledge, and giving people who have the epistemic position of subordinated knowledges legitimacy, were the true keys to social transformation. You're right, I think, to suggest that we are struggling with the consequences of a kind of lost faith in this belief or at the very least with the recognition that the right has engineered a project to 'raise' consciousnesses on its behalf and to situate different bodies and interests in the frame of subordination (think white injury). In the post-truth era, 'knowledge' is whatever your favourite news outlet or blog or social media tells you. If the present is post-critique in terms of political culture, it is not post-suspicious reading. On the contrary, conspiracy is everywhere. You can talk until you are blue in the face about the facts of climate change, for instance, and people will still say 'there's no global warming; it's all fake news'. 
Salla: What do you think the debates around critique might be symptomatic of, especially in terms of how the cultural relationship to knowledge has transformed?

Robyn: I don't really have an answer to this question as I'm not sure that what we are witnessing is a symptom in the usual sense of the word. Many of the debates seem to be precisely about what critics say they are contesting - though critics are not always contesting the same things, which is what I was pointing to earlier in differentiating between the projects of Felski and Sedgwick, or more broadly between Felski's notion of post critique and Chernivasky's. There are lots of things going on for those who have an optimistic investment in the designation 'post-critique', but one is surely about the desire to restore something of the centrality of literature. I tend to think of this restoration as being about an affective relationship to the object, one that arises in part because of the way that the technologies of everyday life have abandoned older practices of reading that were cultivated in relation to the literary object. The historical shift from print to digital culture seems bound up in calls for slow reading, descriptive reading, and a return to close reading.

Salla: But are those questions of critique? I am thinking about the desire to be able to say something about a text beyond the frameworks that have been defined as critique. I guess my question is: are aesthetic experiences or judgments about objects always political? Or is it our epistemic habit to assume that we need to foreground the politics of our readings, our analyses, claims and so on?

Robyn: In the book mentioned earlier, in a chapter on literature and popular culture, Cherniavsky makes this interesting argument that popular culture is a resource for diagnosing the conditions of the political present. She does this in much more interesting ways than we usually find in critical theory and cultural studies as she actually has an argument for why she wants to look at these kind of texts and what they can do that academic modes of analysis and critique cannot. One piece of it is about the temporality of the present. For her, popular culture has been grappling with what she calls the 'derealization' of politics for a long time, while left academic criticism has been tied to critique, which is fundamentally a realist project - we reveal the illusion in order to destroy the power that feeds off it. But in that quest for demystification, critics are all-too prone to finding objects of study that are dumber than we are. For Chernivasky, popular culture offers some smart texts that have been dealing with the transformed conditions of the political field, texts as disparate as 'Battlestar Galactica', White Boy Shuffle, and the discourses of the Occupy Movement. In her hands, the aesthetic and the political are linked in some counterintuitive ways, especially since popular culture has often been considered most in need of ideological critique.

Salla: This reminds me of the emphasis on description as a means for achieving a different kind of critique, something I find interesting...

Robyn: Yes, I think here of Heather Love's most recent work. She turns to description through the social sciences in order to make a larger argument about the problem of method or more precisely anti-methodological thinking in queer theory. I think that her arguments, like when she reads Samuel Delaney and applauds his deft ability to describe the complex and often contradictory terrain of everyday life, present an important challenge to queer theory, especially when its political investments predetermine the shape and scope of its interest in particular objects.

Queer theory's critique of gay marriage is a case in point. Queer theory tends to read participation in the marriage movement univocally, as a complicitious desire for normativity. Here desire has none of the complexity that it otherwise carries in queer theoretical inquiry, and I would venture to say that the critique of gay marriage has actually circumscribed scholarly investigations that might illuminate the diversity of reasons that move people toward marriage - economics and immigration status being two big ones, as Eithne Luibheid has discussed. Description is an interesting starting point for considering what people desire, including the way radical imaginaries do and don't align with political projects and institutions. Maggie Nelson does a good job of making these issues palpable to queer theoretical audiences in her memoir The Argonauts.

Salla: Do you have your own epistemic habit?

Robyn: I don't know what that means. (Laughs) Tell me...

Salla: This might be a difficult question to ask someone who has such an analytical mind for questioning the question, and constantly making visible your own epistemic habits - would that be a description of your epistemic habit? 
Robyn: Yes, I suppose so. My habit is to understand my habit - and everybody else's too! And especially when our habits become routine and deeply routinised, even as I recognise that people get a lot of pleasure from routine.

Salla: Could you talk a little bit about the psychoanalytic dimensions to critique and your own relationship to your objects? And maybe say something about the value of psychoanalysis as criticism and the value of being able to think about your own practice through psychoanalysis as also a form of cultural critique?

Robyn: Object Lessons was written out of a need to say that our relationship to our objects, in the fields that I care the most about, is not innocent - or more acutely, that fields that understand themselves as having not only a political impulse but a political rationale and obligation can never have innocent relations to their objects of study. There are multiple aspects of these claims and it was largely through a psychoanalytic idiom that I worked to explore them. My point was not so much to launch a critique but to offer a diagnosis, one that was not intended to demand or offer a cure. How do you cure desire? Psychoanalysis is brilliant at teaching us how we use objects for our own ends and it on this score that I side with the work on the critique of critique that wants to question the critic's sovereignty. My own work is implicated in these problems: I was trained in the tradition of critique and I see in my early publications the impulse to destroy my object of study in order to show what it didn't know about itself. So, good for me - now I can see what my object of study does and doesn't know. The paradox of course is that I actually need its failure in order to produce the positivity for my own thought.

Salla: There is a strong emphasis on and critique of a politics of exclusion in both gender/queer studies and in political activist work. We can see this kind of critique as a desire for inclusion and recognition, and as a way of undoing oppression. These critiques (against the category of woman, for example) have become routinised gestures, so the question is: does critique lose its political edge when it is predictable as a habit?

Robyn: If one of the suppositions about critique is that it operates by jolting people into a new relationship to power, knowledge, everyday life, or what have you, the risk of repetition is a kind of political numbing even as the habitual force of specific contentions works to solidify alliances between those who already believe. Solidarity on one side; deafness on the other. That's the conundrum in a political field that bends toward political struggle as shared belief. When it comes to academic critique, the risk is similar; repetition solidifies the political imaginaries of fields; people belong to fields based on their ability to cite the governing narrative, which includes the prevailing contestations to previously governing narratives. Intersectionality comes to mind here. It emerged as a critique of the disavowed universalism that is at the heart of a lot of claims to the political in feminist work. Today it is established critical doctrine and much of the discussion of its ongoing utility is over whether its critique has been muted, appropriated, etc. The more its value is repeated, the more worry there is that it has lost its critical edge. In my chapter on intersectionality in Object Lessons, I tried to grapple with the political desire of intersectional claims, how the necessary demand for a comprehensive account of the structures of power within which subjects are constructed was not without universal commitments. A desire for a map without exclusion, hence a project of universal inclusion. So far this part of the book's argument has not been taken up.

Salla: It's interesting because that is exactly what Toril Moi says about intersectionality too in her new book The Revolution of the Ordinary (2017). Critiquing this vision of wholeness internal to the debates around the concept.

Robyn: I'm not against universalising imperatives. I'd just want to lean much more heavily on the implications of universal inclusion through particularity. But the larger issue here might be about the implicit search for a practice or perspective that will do no harm, that entails no violence. I was actually talking to my undergraduate class about this today, about the desire to do no harm. I have a colleague, Wahnemma Lubiano, who talks eloquently about people's desire to be heroic political subjects. This is the subject that always does right under all conditions and can never conceive of itself as doing wrong. It certainly can't countenance the fact that to get what one wants means extinguishing - to use Elisabeth Povinelli's terms - the life that somebody else has or wants. There is work now that is really trying to grapple with this. But such grappling is at odds with a political scene finetuned to calling out complicities. I'm reminded increasingly of the attack mode of the lesbian feminist 1970s where everything from the rigor of your Marxist analysis to your shaving habits was taken as a sign of your political commitments - or their violation. Students have talked to me in office hours about their fear that they might get kicked out of their social and political groups if they are considered insufficiently queer. The historical repetition is unnerving.

Salla: This is how political actions and critique are entangled in a complicated way? 
Robyn: People want to make good political decisions, to engender the worlds we struggle to imagine. That is the aim of political action and the intense need it speaks to that the future one wants becomes a reality here and now. I understand that, but I agree with Wahneema that politics means getting dirty. Politics, not in the abstract, not as a theoretical issue, is about often about how you weigh one bad choice against another. Rarely are the available choices coherent with what you really want. In queer studies there is so much angst about the tension between the utopic future and the political negotiations that attend survival in the scene of the present. But people have to negotiate, that's where everyday life lives. It's that negotiation that most interests me - between fidelity to our political aspirations and the politics entailed in the space of ordinary life.

Salla: I attended a panel on the pedagogy of trans studies here at Duke a few days ago, where one of the main arguments was that trans should be analytically approached just like any other concept of gender. Joan Scott's work on experience, Butler's work on gender and Foucault on historicity and genealogy were referenced as the basis for this analytical framework. A question was raised about the pedagogical implications of this, as students come to gender and trans studies classes because of their identities and political commitments only to find them taken apart. This tension between being engaged in a politics around identity that is deconstructed in the name of critique, reminds me of the problematic of the personal and the theoretical - what happens when personal identity and experience are grinded through such deconstructive machinery?

Robyn: It's the pedagogical balance we have to perform in gender studies, isn't it? To cultivate and respect the kind of personal political investments that brings students to the space of the classroom while also pushing for a critical engagement with the complexity of identity, identity politics, and political identifications. I remember when feminist studies first took up theory in the 1980s, we were out of our minds with suspicioun of its allure. What was this if not an appropriation of a set of embodied experiences into an elite knowledge form? This question has never gone away.

Salla: There can also be a liberating experience in anti-identitarian work - queer theory offers that.

Robyn: For sure. Butler putting "I" in quotation marks, going to Yale to "be" a lesbian: she performs the inescapable utility of grammatical personhood and identity while undermining it. That was the big poststructuralist lesson. But we've always wanted it both ways, to deploy identity as a form of experiential truth and to protest identity's carceral logics. It's the double-bind that is fascinating and for queer theory it is evinced in some of the most widely regarded foundational work. Butler's project was to put the sovereignty of the subject and of subject identities under erasure but always from the position of authority that her own identities granted. Sedgwick was never anti-identitarian in this way. She couldn't be. Hers was always a claim for cross identifications, and it was vehemently resisted by many people for a long time.

Salla: One routinised gesture that I am interested in concerns the question of complicity that comes up in writing about others as if the writing in itself performs a kind of violence. Is there critique without the charge of complicity?

Robyn: Well, I want to say there can be. But we don't have a conception of historical change that can be articulated without a moral subject and that's a very big problem for left criticism and politics. I am very attracted to Foucault because of the way he mutes the significance of the human in his historical arc; it's the thing that people are often most angry about, but it offers some respite from the fantasy of the individual agent whose noncomplicity is somehow possible. While there are certainly degrees of complicity, the idea of the non-complicit subject is ultimately apolitical. I worked with a student at Duke, Sophie Smith, who wrote a fantastic dissertation about life on the border in Arizona. One of the things that fascinated her was the political lay of the land in which homesteaders, no matter their political affiliations, would create gates so that people could pass through their property or provide access to water wells not because they necessarily had a humanitarian interest, but because they didn't want to find dead bodies on their land. But what they did saved lives. One of her chapters traced the way people's different interests, unassimilable into any single political project or position, nonetheless contributed to left political change. This is very compelling. Things get done, not because people have a shared political vision, but because people's different interests have converged productively in relationship to a specific political situation. I don't think that the left would even know how to help orchestrate such a scenario and it is hard to imagine academic left criticism suspending ideals of community and shared political belief given how strongly these work to consolidate disciplinary practices and identities. 
Salla: I think that is an excellent example - and becomes a question of how critical fields theorise power and understand that.

Robyn: Yes, and how we think about politics and historical change.

Salla: This example reminds me of different understandings of power and the political in contemporary critique as routinised gestures - do you want to say something about that?

Robyn: As I say in Object Lessons, I'm less interested in political imaginaries than I am in the imaginary of the political. That move right there might be my epistemic habit. It's the 'wait a minute' moment, let's actually consider what constitutes politics. What do we lose when we assume its meaning is self-evident? When does the category of the political emerge historically as a foundational feature of social life? Along these lines, I'm fascinated by the history of the idea of revolution and the way it is used on the left and the right today. It's a distinctly modern concept and especially paradoxical as the figure of a political imaginary to undo the various deceptions about democracy, rationality, and the human at the heart of modernity.

Salla: The complicated relationship to the political and critique reminds me of your piece: The times we're in: Queer feminist criticism and the reparative 'turn', in which you write, I think beautifully, about the existential and moral difficulties in relationship to your mother who suffered from bipolar. You argue that critique, much like other hermeneutic frameworks, can't respond to those kinds of difficulties.

Robyn: The argument of the piece and its rhetorical strategy sought to mobilise the affective relation to my mother to demonstrate the incapacity of the epistemological, which is the core of critique, as our go-to strategy for political struggle. How do you convince someone that their reality is a fantasy or that what they fear is not real? What does it mean, in the face of such a condition as bipolar, to make the same pedagogical move over and over that seeks to teach the subject about the condition of her condition? It took me years, but I finally started to see that the kind of mental maneuvers that sustained me - that saved me really - were of no use for my mother. Critique was never a cure; knowledge did not set her free.

Today we are living, in the US at least, in a political culture that reminds me of my childhood. The landscape is without clear emotional signposts; little epistemological intervention sticks; every day bring a new whiplash. This is the affective consequence of the derealisation that Cherniavsky talks about and no doubt why her latest project is about mania. As you can see, it is this trajectory of the conversation about post-critique that most engages me, even as we do need to be closer and slower readers and to describe the complexity of the issues that face us without thinking we know in advance how to wring political judgments from them.

Fortunately there are a lot of people who are practising these kinds of self-critical reflections, not as a way to generate more critique or to fashion criticism as political transgression but as a way to live in, if not also with, the distinctly awful conditions of our present. For now, this is about as optimistic as I can get.

\section{REFERENCES}

Dean, T. and Wiegman, R. (2013). What Does Critique Want? A Critical Exchange, English Language Notes, 51(2), pp. 107-122.

Cherniavsky, E. (2017). Neocitizenship: Political Culture after Democracy. New York: New York University Press.

Felski, R. (2015). The Limits of Critique. Chicago: The University of Chicago Press.

Love, H. (2015). Doing Being Deviant: Deviance Studies, Description, and the Queer Ordinary. Differences, 26(1), pp. $74-95$.

Moi, T. (2017). The Revolution of the Ordinary. Chicago: The University of Chicago Press.

Nelson, M. (2015). The Agronauts. London: Greywolf Press.

Povinelli, E.A. (2014). On Suicide, and Other Forms of Social Extinguishment. In: J. Potts and D. Stout, eds., Theory Aside (pp. 78-97). Durham: Duke University Press.

Rooney, E. (2010). Live Free or Describe: The Reading Effect and the Persistence of Form. Differences, (21)3, pp. 112-139.

Sedgwick, E.K. (2003). Paranoid Reading and Reparative Reading: or, You're So Paranoid, You Probably Think This Introduction Is about You. In: E.K. Sedgwick, ed., Touching Feeling: Affect, Pedagogy, Performativity (pp. 123151). Durham: Duke University Press.

Smith, S. (2016). The Hole in the Fence: Policing, Peril, and Possibility in the US-Mexico Border Zone, 1994-Present. Dissertation, Duke University.

Wiegman, R. (2012). Object Lessons. Durham: Duke University Press. 
Wiegman, R. (2014). The times we're in: Feminist criticism and the reparative 'turn'. Feminist Theory, (15)1, pp. 423.

Weed, E. (2012). The Way We Read Now. History of the Present, (2)1, pp. 95-106.

\section{FURTHER READING}

Anker, E. and Felski, R. (2017). Introduction. In: E. Anker and R. Felski, eds., Critique and Postrritique (pp. 1-28). Durham: Duke University Press.

Best, S. and Marcus, S. (eds) (2009). Representations, (108)1, Fall 2009.

Chew, D. (2015). We Have Never Been Critical. We, Reading, Now. Colloquy curated by Dalglish Chew and Julie Orlemanski. Arcade. Available at: http://arcade.stanford.edu/content/we-have-never-been-critical (Accessed 20 August 2017).

Di, L. and Jeffrey, R. (2014). Criticism after Critique Aesthetics, Literature, and the Political. New York: Palgrave Macmillan.

Wilson, E. (2015). Gut Feminism. Durham: Duke University Press.

Citation: Wiegman, R. and Peltonen, S. (2017). Investigating Desires, Political Projects and Epistemic Habits in Academic Feminism: A Conversation with Robyn Wiegman. Feminist Encounters: A Journal of Critical Studies in Culture and Politics, 1(1), 11. https://doi.org/10.20897/femenc.201711

Copyright (C) 2017 by Author/s and Licensed by Lectito BV, Netherlands. This is an open access article distributed under the Creative Commons Attribution License which permits unrestricted use, distribution, and reproduction in any medium, provided the original work is properly cited. 
http://www.lectitopublishing.nl

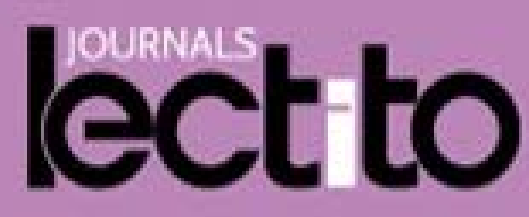

